\title{
Studies in wage bargaining : the influence of taxes and social security contributions on wages
}

Citation for published version (APA):

van Veen, A. P. (1997). Studies in wage bargaining : the influence of taxes and social security contributions on wages. [Doctoral Thesis, Maastricht University]. Datawyse / Universitaire Pers Maastricht. https://doi.org/10.26481/dis.19970912av

Document status and date:

Published: 01/01/1997

DOI:

10.26481/dis.19970912av

Document Version:

Publisher's PDF, also known as Version of record

\section{Please check the document version of this publication:}

- A submitted manuscript is the version of the article upon submission and before peer-review. There can be important differences between the submitted version and the official published version of record.

People interested in the research are advised to contact the author for the final version of the publication, or visit the DOI to the publisher's website.

- The final author version and the galley proof are versions of the publication after peer review.

- The final published version features the final layout of the paper including the volume, issue and page numbers.

Link to publication

\footnotetext{
General rights rights.

- You may freely distribute the URL identifying the publication in the public portal. please follow below link for the End User Agreement:

www.umlib.nl/taverne-license

Take down policy

If you believe that this document breaches copyright please contact us at:

repository@maastrichtuniversity.nl

providing details and we will investigate your claim.
}

Copyright and moral rights for the publications made accessible in the public portal are retained by the authors and/or other copyright owners and it is a condition of accessing publications that users recognise and abide by the legal requirements associated with these

- Users may download and print one copy of any publication from the public portal for the purpose of private study or research.

- You may not further distribute the material or use it for any profit-making activity or commercial gain

If the publication is distributed under the terms of Article $25 \mathrm{fa}$ of the Dutch Copyright Act, indicated by the "Taverne" license above, 
Studies in Wage Bargaining 
ISBN 90-9010328-7

C Tom van Veen 1997

Druk: Datawyse Maastricht 


\section{Studies in Wage Bargaining}

The influence of taxes and social security contributions on wages

\section{PROEFSCHRIFT}

ter verkrijging van de graad van doctor aan de Universiteit Maastricht

op gezag van de Rector Magnificus, Prof. mr. M.J. Cohen, volgens het besluit van het College van Decanen, in het openbaar te verdedigen op vrijdag 12 september 1997 om 14.00 uur

door

Anthonius Peter van Veen

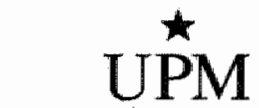

UNIVERSITAIRE PEERS WAASTRICHT 
Promotor:

Prof. dr. J. Muysken

Beoordelingscommissie:

Prof. dr. J.A.H. Maks (voorzitter)

Prof. dr. P.P. de Gijsel (Universiteit Maastrich $/$ Universiteit van Osnabrück)

Prof. dr. A. Knoester (Erasmus Universiteit Rotterdam/OCfEB, Research

Centre for Economic Policy (Onderzoekcentrum Financieel Economisch Beleid))

Prof. dr. H.J.M. Peters 
To my parents

To my "mates" Thea

Max

Jolien

Simon 


\section{CONTENTS}

List of symbols

Preface

Chapter 1 Introduction

1.1 Introduction

1.2 Wage bargaining and wage drift

1.3 The shifting problem

1.4 The aim of this study

1.5 Overview over this study

1.5.1 General overview

1.5.2 The chapters

1.6 Methodology

1.7 Relation to other work in this field

\section{PART I: STUDIES IN WAGE FORMATION}

Chapter 2 Wage formation in the Netherlands

2.1 Introduction

2.2 The period 1945 - 1964: a policy of guided wages 18

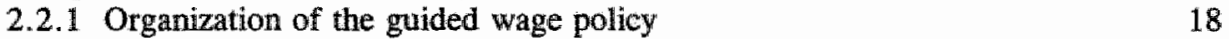

2.2.2 Implementation of guided wage policy 21

$\begin{array}{ll}2.2 .3 \text { Guided wage policy and market forces } & 22\end{array}$

2.3 The period after $1964 \quad 24$

2.3.1 The organization of wage bargaining 24

2.3.2 The players $\quad 25$

2.3.3 The role of the central level in Dutch wage bargaining 26

2.4 Contract wages and wage drift $\quad 32$

2.4.1 Wage drift $\quad 32$

2.4.2 Measurement and development of wage drift 33

2.5 Conclusions $\quad 36$

$\begin{array}{ll}\text { Appendix } 2 \text { List of the used abbreviations } & 38\end{array}$

Chapter 3 Union behaviour and wage bargaining 39

3.1 Introduction $\quad 39$

3.2 Prelliminary remarks $\quad 40$

3.3 Wages, employment and contracts $\quad 42$

3.3.1 Leontief's analysis $\quad 42$

3.3.2 The labour demand equilibrium model 45

3.3.3 Right-to-manage $\quad 47$

3.3.4 The contract curve equilibrium model 50

3.3.5 A summary: the (encompassing) analysis of Manning"s sequential bargaining model $\quad 54$

3.4 Utility functions and the bargaining solution 58

3.4.1 The union utility function $\quad 58$

3.4.2 Risk aversion and the bargaining solution 62 
3.5 Empirical Research

3.5.1 The labour demand equilibrium model and the contract curve equilibrium model compared

3.5.2 The right-to-manage model and the labour demand equilibrium model

3.5.3 Conclusions

3.6.1 Employment contingencies $\quad 70$

3.6.2 Instability of the efficient bargain solution $\quad 72$

3.6.3 Union utility Functions 73

$\begin{array}{ll}3.7 \text { Conclusions } & 74\end{array}$

Appendix $3 \mathrm{~A}$ closer look at the relation between the monopoly model, the right-to-manage model and the efficient bargain model 75

Chapter 4 A bargaining approach to wage drift 79

4.1 Introduction 79

4.2 The Moene/Holden Model $\quad 81$

4.2.1 The bargaining environment 81

4.2.2 The determination of the wage rate and profits 82

4.2.3 The determination of employment $\quad 83$

4.2.4 Evaluation of the model $\quad 85$

4.3 An efficiency wage based model of local wage bargaining 87

4.3.1 The determination of the wage rate $\quad 87$

4.3.2 The determination of employment 91

4.4 Evaluation of the model. 98

$\begin{array}{lll}4.5 & \text { Conclusions } & 100\end{array}$

$\begin{array}{ll}\text { Appendix } 4 & 101\end{array}$

Chapter 5 Centralization and decentralization and Dutch labour relations 105

$\begin{array}{lll}5.1 \text { Introduction } & 105\end{array}$

5.2 The relation between centralization and decentralization and economic performance

$\begin{array}{ll}\text { 5.2.1 Theoretical considerations } & 107\end{array}$

5.2.1.1 The start: the Prisoner's Dilemma Game 107

5.2.1.2 The continuation: spillover effects 109

5.3 Coordination between unions in analytical models of wage setting: some applications

5.4 The relation between centralization of wage bargaining and economic performance: empirical evidence

5.5 Conclusions

\section{PART II: TAXES AND WAGES}

Chapter 6 Some stylized facts regarding the development of the wedge and its components

6.1 Introduction

6.2 The measurement of the wedge

6.3 The development of the wedge in the Netherlands 1960-1993

6.4 The influence of the tax reform of 1989 
6.5 A comparison between the Netherlands and OECD countries 138

6.6 Conclusions

Appendix 6A A note on the wedge data for an individual employee

Appendix $6 \mathrm{~B}$ A note on the wedge data in the national accounts

Appendix 6C The development of the total wedge; the Netherlands vs 9 OECD countries.

Appendix 6D The development of employees" contributions to social security: the Netherlands vs 9 OECD countries

Appendix 6E The development of employers' contributions to social security; the Netherlands vs 9 OECD countries

Appendix 6F The development of average income taxes; the Netherlands vs 9 OECD countries

Appendix 6G The development of employees' part of the wedge; the Netherlands vs 9 OECD countries

Chapter 7 Taxes and wages and Dalton's Law I: the market clearing model

7.1 Introduction

7.2 Tax incidence and tax shifting

7.2.1 Theoretical framework of tax shifting on competitive markets

7.3 Dalton's Law

161

7.4 Implications of Dalton's Law

164

7.5 Dalton's Law and tax equivalence

7.6 Conclusions

Chapter 8 Taxes and wages and Dalton's Law II: wage bargaining models

8.1 Introduction

8.2 Wage bargaining

8.2.1 Wage bargaining: a simple model

8.2.2 A right-to-manage model of wage bargaining

8.3 Empirical Results: the Netherlands

8.3.1 Earlier research for the Netherlands

8.3.2 An extension of the empirical analyses

8.4 Research in other OECD countries

8.5 Conclusions

\section{PART III: TAXES IN A THREE-TIER WAGE BARGAINING MODEL:} the case of the Netherlands

Chapter 9 A model of tax shifting in a three-tier wage bargaining system

9.2 Relation to other literature concerning multi-tier wage bargaining 200

9.3 The central level 
9.4 From the central level to the decentralized level: industry bargaining 214

$\begin{array}{ll}9.5 & \text { Bargaining at the level of the firm } \\ 9.6 & 219\end{array}$

\begin{tabular}{ll}
9.6 Conclusions & 221 \\
\hline & 223
\end{tabular}

$\begin{array}{ll}\text { Appendix } 9 & 223\end{array}$

$\begin{array}{ll}\text { Chapter } 10 \text { Summary and Conclusions } & 225\end{array}$

10.1 Summary and conclusions ? 225

10.2 Directions for further research $\quad 228$

References

Summary (in Dutch)

Curriculum Vitae 


\section{List of symbols}

Throughout this book I use some synonyms. The names monopoly model and labont demand equilibrim model are synonym. The same holds for the contract curve equilibritum model with as synonyms the contract curve model and the efficient bargain model. Since I assume constant prices equal to 1, I used the words marginal revenue of labour, marginal revenue product of labour and marginal product of labour as synonyms.

Derivatives are denoted by $d(.) / d($.$) . If U=(W, L)$ is a utility function where utility (U) depends on wages (W) and employment (L), then dU/dW is the derivative of $U$ to $W$.

Partial derivatives are denoted by a subscript. Hence, if $R(L)$ is a reventue function with revenue $(R)$ depending on employment $(L)$, then the partial derivative is denoted by $R_{L}$. However, given the complexity of the notations, chapter 4 is an exception: in this chapter I denote the partial derivate by $R^{\prime}(L)$.

\section{General}

bargaining power

exchange rate

eec

erc

it

$\mathbb{K}$

employees' contribution for social security

employers' contribution for social security

income taxes

L

Utility

Unemployment income

Utillity per union member

Utility function with arguments between brackets

marginal utility of $x$ (partial (first) dertivative of $U(x, y)$ to $x$ )

First derivative of $U$ to $x$

nominal wages; gross wages (ch. 6-9)

$\ln (W)$

Wage in absence of taxes; this can be an equilibrium wage or a bargained wage (chapters 6-9)

$\ln \left(w^{*}\right)$

Wedge

$\ln (W d)$

Wage costs

$\operatorname{In}(\mathrm{Wc})$

Net Wage

$\ln (\mathrm{Wn})$

Nominal income

$\left(W^{*} / W\right)$

$\ln (T)$

retention ratio (expressed in terms of gross wages) 


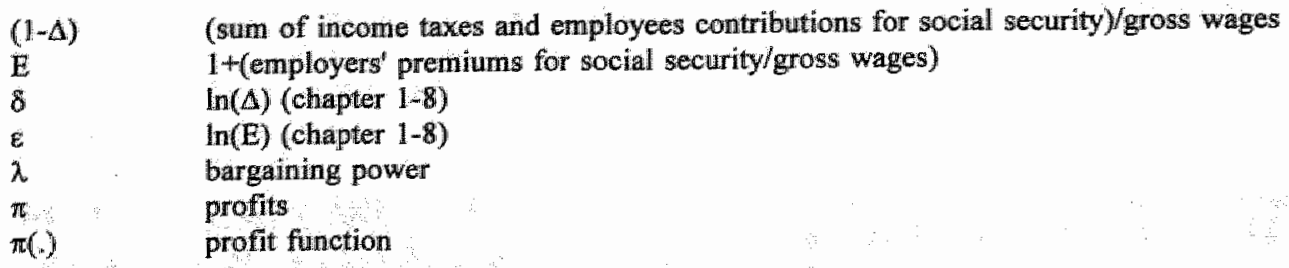

Apart from the general symbols, I have used specific variables in specific chapters. Note that these variables can have different meanings in different chapters.

Chapter 2

W

y

Chapter 3

$c, p_{1} q_{1} \lambda$

E

h

$L^{M}, L(m)$

$\mathrm{W}^{\mathrm{M}}, \mathrm{W}(\mathrm{m})$

$L^{\mathrm{rtm}} \mathrm{L}(\mathrm{R})$

$\mathrm{W}^{\mathrm{ntan}}{ }_{\text {; }} \mathrm{W}(\mathrm{R})$

$L^{\text {eb }}$

$W^{e b}$

L*

W*

$\mathrm{M}$

S(W)

$\varepsilon^{W}$

\section{Chapter 4}

$c$

e

L*

$\mathbb{L}_{0}$

Lis

9

W

W*

W.

$W_{0}$

$w_{1}$

$W_{L}$

$\Omega$

$x_{\text {mini }}$

$\pi_{\text {imax }}$

Chapter 6

WWC

wn

$\beta$
Total wage costs

Real production

bargaining power

Employed union members

hours of work

solution for employment in the monopoly model

solution for the wage rate in the monopoly model

solution for employment in the right to manage model

solution for the wage rate in the right to manage model

solution for employment in the efficient bargain model

solution for the wage rate in the efficient bargain model

reference employment (Not in figure 3.6)

reference wage (Not in figure 3.6 )

Union membership

Arrow Pratt measure of absolute risk aversion

Elasticity of wages with respect to employment

bargaining power of employers at the level of the firm

Effort

Employment level according to the Solow condition

Employment if $c=0$

Employment if $\mathrm{c}=1$

Wage level when there is no agreement at the level of the firm

Fina』 wage, i.e. $q+$ wage drift

Wage rate according to the Sollow condition

Wage rate above which the labour demand curve is downward sloping

Wage rate if $\mathrm{c}=0$

Wage rate if $\mathrm{c}=1$

Elasticity of wages with respect to employment

The fraction of the normal production that will be realized in case of disagreement

Minimum level of profits

Maximum level of profits

Real wage cost

Real net wages

Weight of domestic production prices in pc 


$\begin{array}{ll}A_{3} B & \text { Scale parameters } \\ \mathrm{L}^{\mathrm{d}} & \text { Labour Demand } \\ \mathrm{L}^{\mathrm{S}} & \text { Labour Supply } \\ \mathrm{y} & \text { Real production } \\ \alpha & \text { Labour elasticity of supply } \\ \beta & \text { Labour elasticity of demand } \\ \gamma & \text { Shifting parameter }\end{array}$

\section{Chapter 8}

b

\section{Replacement ratio}

$\ln (\mathrm{L})$

Real wage claim

Real wage offer

Maximum real wage offer as a fraction of $Y$

Minimum acceptable real wage as a fraction of $Y$

Total unemployment

Long-term unemployment

National income

Elasticity of substitution

Minimum labour share in national income

Minimum acceptable level of real profits as a fraction of $Y$

bargaining power

\section{Chapter 9}

bargaining power at the level of the firm

Amount of Public Goods

Amount of public goods at the level of the industry

Employment at the level of the industry

Employment at the level of the firm

Indirect taxes

Utility of the central union

Utility of the industry union

Recommended wage rate that is agreed upon at the central level

Minimum wage that is desired by the union at the central level

Wage rate at the industry level

Wage rate at the level of the firm

bargaining power at the centrail level

bargaining power at the industry level

retention ratio (expressed in terms of gross wages)

(sum of income taxes and employees contributions for social security)/gross wages $1+$ (employers' premiums for social security/gross wages)

bargaining power at the central level

utility elasticity with respect to net wages

utility elasticity with respect to employment

profits at the level of the industry 


\section{PREFACE}

When I studied economics in Groningen, I took a course in labour economics, lectured by the late prof. C. de Galan. Later on, I have worked as a student-assistant under his guidance. His lectures impressed me because of his method of analysis: a mixture of theoretical insights and political and institutional facts, applied to the situation on the Dutch labour market. However, since this course was meant for students in economics, sociology and psychology, the focus was on the use of results from theoretical analyses in economics to labour market problems instead of on the analyses itself. But since then, I remained very interested in labour market problems, especially in wage negotiations and the role of unions in the Dutch labour relations and when I started working in Maastricht it was "natural" to choose a subject in this field within the research project on "Labour markets and labour organizations".

Especially the integration of game theory in wage bargaining theories and the role of unions in a so-called welfare state, has attracted my attention. In the spirit of de Galan, I started an analysis from the situation on the Dutch labour market. The discussions with Wil Albeda and Piet Keizer have been very helpful in this respect. In Maastricht, I came to work with Joan Muysken. Joan convinced me that in addition to a de Galan type of analysis, a formal analysis is necessary as well, to sharpen the ideas and the conclusions. In my view, this kind of a "de Galan-Muysken" approach is a good way to analyse labour market problems. Hence, in this thesis you find both institutional facts and a formal analysis concerning wage bargaining.

In this preface I want to thank a number of people for their cooperation in research or other activities. First I owe a lot to Joan Muysken, for being a patient, subtle and creative supervisor and for being the very nice and stimulating person he is. Second, I thank the thesis committee for their willingness to judge this thesis. Hans Maks gave a number of useful suggestions for improvements. Since we met for the first time, Anthonie Knoester has always showed his interest in my research. Hans Peters introduced me into game theory and has been willing to read and discuss parts of my work in previous stages. Special thanks are due to Peter de Gijsel. Peter has been a nice, inspiring and very stimulating colleague, with a balanced view on labour market problems and how to analyse them. Third, in writing this thesis, I have benefited a lot from discussions with (former) colleagues. I would like to mention in particular Wil Albeda, Lex Borghans, Frank Cörvers, Lei Delsen (University of Nijmegen), Hans de Graaff, Piet Keizer, Marcel Lever, Anne van der Veen (University of Twente), Guido Wolfs. I owe some of them for their permission to use parts of joint work in this thesis. Special thanks are due to Erik de Regt who deserves credits for his willingness and ability to discuss and solve all kinds of problems and for being a nice, helpful and stimulating colleague. Guido Vrencken, Mark Sanders, Marieke Rensman, Ruud Doorenbos, Egbert Jongen and Riccardo Welters, have assisted at various stages of the research. Fourth, Norbert Janssen (now Bank of England), Clemens Kool and 
Lilian Raetsen have always been among my dearest colleagues and friends. Most of my teaching has been in cooperation with Norbert and Clemens. Although Norbert has left the University of Maastricht, I still keep good memories to our cooperation. The charming personality of Clemens in combination with the willingness to discuss all kinds of problems has always been a valuable non-pecuniary fringe benefit in my work. Apart from being a very nice colleague, Lilian has supported me throughout my struggles with wpx:y. Without her ability to solve all kinds of editing problems this thesis would have looked quite different (in a negative sense). Moreover, and not less important, she enabled me to stay in Australia before this book was camera-ready for print. Further I owe Bob Wilkinson for his check of the English language in this thesis. His suggestions certainly improved the readability of this thesis.

Fifth, I want to thank my friends from the "Wie Wie Zoe Zoe Wie Zoe" orchestra for their friendship and their ability to shift my interest to music for at least "dreij daog" ( 3 days) a year.

Finally, family support is a necessary requirement to finish a thesis. I am happy that my family gave me this support and gave me the freedom to let me work on this thesis, whenever I wanted to. Therefore, I thank my parents and the kids Max, Jolien and Simon for being there. The heaviest burden, however, was borne by Thea, my wife. She deserves special thanks for always being there.

Tom van Veen, december 1996 


\section{Chapter 1}

\section{INTRODUCTION}

This chapter starts with an oyerview, I diseuss the problens the stady focuses on, the strueture of the thesis, the methodology and the "added value" of this study in relation to other work in this field.

\subsection{Introduction}

This study discusses the organization of labour relations, wage formation and the role of taxes and contributions for social security in the wage setting process in the Netherlands. Basically, this study concerns two phenomena that are worthy of investigation: the way wages are set in the Netherlands and the effects of the high income taxes and contributions for social security that must be paid by both employers and employees on the wages. ${ }^{1}$

One of the major problems that has occurred since the second oil crisis of 1979 seems to have been the shifting of taxes and contributions for social security on to wages. This means that a rise in taxes is "translated" into a rise in wages. A lot of theoretical and empirical research has been dedicated to this phenomenon. It goes without saying that this kind of shifting can cause serious problems for a Dutch-like welfare state, especially when economic growth slows down. Increases in wages, unemployment and premiums will become interrelated in an upward spiral and economic performance deteriorates. In this respect, Knoester (1983) argues that instead of a Havelmo effect, an Inverted Haavelmo effect results from a tax-financed increase in government expenditures.

An interesting question is whether this shifting process is related to the wage setting process in the Netherlands. The Dutch wage setting process is rather complicated because it is a mixture of centralized and decentralized wage negotiations. Centralized bargaining is between all-encompassing organizations of employers and employees, while in decentralized negotiations industry federations of employers and unions are involved. If the goals of the encompassing organizations differ from those of the local organizations, the above mentioned mixture can cause serious problems. For example, one of the aims of the central negotiations could be to stop a tax-wage-

I This study is not the first in this area; a lot of research has dealt with these topics. Section 1.7 goes into the differences between the present work and earlier research in this field. 
unemployment spiral. Hence, one of the results of the central negotiations could be advice to the industry unions not to increase the wages above a certain level, despite an increase in taxes. However, in decentralized negotiations there is a prisoner's dilemma which results in a wage increase following a tax increase. Hence, although it can be beneficial for a single union to shift taxes and to ask for higher wages, if all unions react in this way the financing of the benefits system can become at stake. This has been recognized by the encompassing organizations in their advice, but due to the difference in position of the nationwide and the industry union, the final wage increase could be too high. In this respect, shifting is not at all beneficial - especially when the interests of the unemployed need to be served, as the unions in the Netherlands claim to do. However, this fact may not be a sufficient motive for unions to moderate their wage demands or their shifting behaviour.

In my view there are some reasons that justify a separate study of the economic consequences of the existence of a wedge on the labour market (note that the wedge is defined as the difference between the wage costs for the employer and the net wage that is received by the employee). First, whereas the value-added tax rate is in the Netherlands about the same as elsewhere in Europe, the difference between wage costs and net wages is larger than in many other European countries. Wage costs are about twice as high as net wages and especially in the seventies there has been rapid growth of the wedge. Second, like any tax change, relative prices change after a change in the wedge. Especially the price ratio between labour and capital deteriorates if labour is taxed via an increase in the wedge and consequently wage costs increase. Depending on the substitution possibilities in the production process the capital-labour ratio may change to the disadvantage of labour. Third, owing to the interrelationship of wages and prices in the Netherlands, an increase in wages has inflationary consequences.

In this context the growing attention for the interrelationship between the wedge, wages, inflation and unemployment must be understood. The following quotations illustrate the growing concern in this field: ${ }^{2}$

"One of the most important causes of the deterioration in international competitiveness is the strong increase in the wage costs. (..) the main factors that have contributed to this increase are the shifting of the rise in taxes on to the wages and the fact that in the process of wage setting

2 These quotes are translations of Dutch texts by the author. 
the deterioration of the terms of trade had not been sufficiently reckoned with" $\left(M N, 1980\right.$, p. 19) ${ }^{3}$

and

"Shifting of the collective burden on to wages was responsible for the fact that real wages increased more than labour productivity. Until the early eighties employees were not prepared to take charge of the increase in the collective burden" (MN, 1985, p. 25).

"Another problem for the labour market is the height of the collective burden in the Netherlands. This leads to relative low net receipts for Dutch employees in comparison with their foreign colleagues.(.) Hence, the wedge explains the problem described of the relative low employment" (MN, 1989, p. 53).

"In addition, in the seventies started a long term increase in the collective burden, which led via shifting processes to an increase in wages" (CEP, 1986, p. 94)

When one realizes that since the 1970 s there has been a shift from employers' to employees' part of the burden, these quotations show among other things that employees have obviously succeeded in shifting the payment of their part of the collective burden despite the legal obligations for payment. This apparently strange result occurs because the economic burden of a tax is not necessarily equal to the legal burden of a tax. Tax shifting explains this difference in the burden of a tax.

Finally, I note that the sketched problems are part of a greater issue that attracks increasing attention: the functioning of the labour market. Wage bargaining is only one aspect; problems conceming employment and unemployment are another major topic and are not discussed in this study. Such problems as the relation between the social security system and unemployment, the relation between wage bargaining and long term unemployment (as in the insider-outsider theories), the relation between

$3 \mathrm{MN}$ is an abbreviation for the "Miljoenennota", the report on the government budget issued by the Treasury; the CEP ("Centraal Economisch Plan") gives the yearly review and forecasts of the performance of the Dutch economy according to the Central Planning Bureau. 
comporatism and employment and unemployment policies demand in my view at least a similar study like the present one. ${ }^{4}$

\subsection{Wage bargaining and wage drift}

In this study, I discuss wage bargaining. Since the 1940s, wage bargaining has gained increasing interest in theories of wage determination. Two branches can be distinguished. The first of which explicitly discusses the bargaining process (Hieser (1970); Johnston (1972); Johnston and Timbrell (1973); Rubinstein (1982); Keizer (1986); while Hicks (1932) also paid attention to the process). In this kind of research the costs and benefits of accepting and of rejecting an offer from the other party are calculated for the bargaining parties. When the benefits of accepting an offer exceed the costs of rejecting it, the offer is accepted and vice-versa. These kind of models allow one to analyse the role and the duration of strikes in the wage bargaining process in particular, of which Elliot (1991, chapter 14) gives a good survey. The second branch stems from the increasing attention for game theory in economics that started in the early eighties, and focuses on analysing the set-up and the character of the bargaining game and the corresponding bargaining solutions. The bargaining process as such is hardly analysed, but the focus is on the analysis of solution concepts that fulfil certain requirements, given the goals of the bargaining parties. In gametheoretic terms; the first branch discusses games in extensive form, while the second discusses games in strategic or normal form. In this study I focus on the second branch, the strategic form games. There are three reasons. First, in this study I do not pay attention to the length of strikes. Second, in my view the models in reduced form are more manageable than the other models. Third, most research that discusses tax shifting is based on some game in reduced form.

Scandinavian economists (Calmfors, Hoel, Holden and Moene) especially have added two topics to the wage bargaining game. The first is the incorporation of the central level in union-firm bargains (Holden (1988) is a typical example). Since the core of this kind of research is the fact that wages are negotiated in several stages, these models are called multi-tier wage bargaining models. In the Scandinavian literature one often finds two-tier wage bargaining models. Chapter 2 will show that the situation in the Netherlands is also best described by a multi-tier wage bargaining model and I start developing such a model in chapter 9. Second, closely related to the multi-tier bargaining is the existence of wage drift because if one calls the central

\footnotetext{
4 For recent studies that stress these aspects of the functioning of the labour market see Den Broedler (1996), Jackman et al. (1996) and Scarpetta (1996).
} 
wage the contract wage, then union-firm bargaining is by definition about wage drift. In game theory, wage drift is often modelled as a bargaining game between a local (firm) union and a firm. This study follows this framework and incorporates efficiency wages in it (chapter 4).

\subsection{The shifting problem}

Apart from wage bargaining, this study deals with the effects of taxes and contributions for social security on wages. In modern welfare states, taxes are levied on firms and workers in order to finance government expenditures. Contributions for sacial security are both paid by employers and by employees and are sometimes called payroll taxes. Although taxes and contributions for social security are paid by employers and employees, this does not imply that the economic burden of the tax is also shared. If, for example, income tax rates increase and employees or their representatives, the unions, succeed in increasing their wage to such an extent that their after-tax wage does not change, the economic burden of this tax falls completely on the employers. ${ }^{5}$ Consequently, although the employees pay for the taxes, there is no tax burden for them. In the words of public finance theory, there is a difference between the statutory burden of the tax and the economic burden of the tax. If such a difference exists, taxes have been shifted. From this example it is immediately clear what consequences shifting can have. If employees or their unions strive after retaining net real wages, a tax increase causes an increase in wages. If the rise in wages results in increased unemployment and higher taxes to pay for unemployment benefits, a taxwage spiral occurs. Such a spiral resembles the well-known price-wage spiral. The existence of a tax-wage spiral can have serious consequences since it hampers the financing of the modern welfare state. Because this finance problem is heavily debated in western European economies, it is worthwhile studying the shifting problem in more detail.

\subsection{The aim of this study}

As will be discussed in 1.7 , there have been a lot of studies concerning tax shifting on the labour market, both for the Netherlands and for other OECD countries. From this research one can conclude that tax shifting is worldwide: notwithstanding how labour relations are organized, economic agents try to shift the financial burden of income

5 Unless they increase their prices. However, because of the strength of the competition in international markets price increases following wage increases can be wery difficult to realize. 
corporatism and employment and unemployment policies demand in my view at least a similar study like the present one. ${ }^{4}$

\subsection{Wage bargaining and wage drift}

In this study, 1 discuss wage bargaining. Since the 1940 s, wage bargaining has gained increasing interest in theories of wage determination. Two branches can be distinguished. The first of which explicitly discusses the bargaining process (Hieser (1970); Johnston (1972); Johnston and Timbrell (1973); Rubinstein (1982); Keizer (1986); while Hicks (1932) also paid attention to the process). In this kind of research the costs and benefits of accepting and of rejecting an offer from the other party are calculated for the bargaining parties. When the benefits of accepting an offer exceed the costs of rejecting it, the offer is accepted and vice-versa. These kind of models allow one to analyse the role and the duration of strikes in the wage bargaining process in particular, of which Elliot (1991, chapter 14) gives a good survey. The second branch stems from the increasing attention for game theory in economics that started in the early eighties, and focuses on analysing the set-up and the character of the bargaining game and the corresponding bargaining solutions. The bargaining process as such is hardly analysed, but the focus is on the analysis of solution concepts that fulfil certain requirements, given the goals of the bargaining parties. In gametheoretic terms, the first branch discusses games in extensive form, while the second discusses games in strategic or normal form. In this study $\mathbb{I}$ focus on the second branch, the strategic form games. There are three reasons. First, in this study I do not pay attention to the length of strikes. Second, in my view the models in reduced form are more manageable than the other models. Third, most research that discusses tax shifting is based on some game in reduced form.

Scandinavian economists (Calmfors, Hoel, Holden and Moene) especially have added two topics to the wage bargaining garne. The first is the incorporation of the central level in union-firm bargains (Holden (1988) is a typical example). Since the core of this kind of research is the fact that wages are negotiated in several stages, these models are called multi-tier wage bargaining models. In the Scandinavian literature one often finds two-tier wage bargaining models. Chapter 2 will show that the situation in the Netherlands is also best described by a multi-tier wage bargaining model and I start developing such a model in chapter 9 . Second, closely related to the multi-tier bargaining is the existence of wage drift because if one calls the central

\footnotetext{
4. For recent studies that stress these aspects of the functioning of the labour market see Den Broeder (1996), Jackman et al. (1996) and Scarpetta (1996).
} 
wage the contract wage, then union-firm bargaining is by definition about wage drift. In game theory, wage drift is often modelled as a bargaining game between a local (firm) union and a firm. This study follows this framework and incorporates efficiency wages in it (chapter 4).

\subsection{The shifting problem}

Apart from wage bargaining, this study deals with the effects of taxes and contributions for social security on wages. In modern welfare states, taxes are levied on firms and workers in order to finance government expenditures. Contributions for social security are both paid by employers and by employees and are sometimes called payroll taxes. Although taxes and contributions for social security are paid by employers and employees, this does not imply that the economic burden of the tax is also shared. If, for example, income tax rates increase and employees or their representatives, the unions, succeed in increasing their wage to such an extent that their after-tax wage does not change, the economic burden of this tax falls completely on the employers. ${ }^{5}$ Consequently, although the employees pay for the taxes, there is no tax burden for them. In the words of public finance theory, there is a difference between the statutory burden of the tax and the economic burden of the tax. If such a difference exists, taxes have been shifted. From this example it is immediately clear what consequences shifting can have. If employees or their unions strive after retaining net real wages, a tax increase causes an increase in wages. If the rise in wages results in increased unemployment and higher taxes to pay for unemployment benefits, a taxwage spiral occurs. Such a spiral resembles the well-known price-wage spiral. The existence of a tax-wage spiral can have serious consequences since it hampers the financing of the modern welfare state. Because this finance problem is heavily debated in western European economies, it is worthwhile studying the shifting problem in more detail.

\subsection{The aim of this study}

As will be discussed in 1.7, there have been a lot of studies concerning tax shifting on the labour market, both for the Netherlands and for other OECD countries. From this research one can conclude that tax shifting is worldwide: notwithstanding how labour relations are organized, economic agents try to shift the financial burden of income

5 Unless they increase their prices. However, because of the strength of the competition in international markets price increases following wage increases can be very difficult to realize. 
taxes. Hence, tax shifting is not an exclusively Dutch phenomenon and as such it has nothing to do with the process of wage formation. However, finding a positive relation between wages and taxes does not imply that all questions concerning the relation between taxes and wages are solved. The theory behind the shifting process especially is "underdeveloped". It is simply assumed that union goals are formulated in terms of real met wages and consequently tax shifting is embodied in union behaviour. One might question this assumption. First, because unions differ to a large extent between countries (e.g. in coverage, in organization, in co-determination, in centralization), union goals need not necessarily be the same worldwide. Second; the existence of wage drift causes a difference between the negotiated wages and the wages that are actually paid. Consequently, the union does not determine the total wage. Further, existing theory about tax shifting from the field of public finance is scarcely used in the analysis of the research results.

These comments imply, in my view, that the relation between tax shifting and wage formation needs to be studied in more detail than has been done so far. Moreover, the application of existing tax shifting theory to union/employers wage bargaining models needs further investigation.

This study aims at gaining insight into these topics. Tax shifting is studied in a specific institutional environment: Dutch negotiations. In other words, I wonder whether the process of wage bargaining and the institutions to match, contributes in a specific way to tax shifting. Further, I aim at relating the existing theory of tax shifting from the field of public finance to modern theories of union behaviour and multi-tier wage bargaining. To summarize, I focus on the following research questions:

1) What are the specific characteristics of wage formation in the Netherlands and how do they fit in existing wage bargaining theories?

2) How can wage drift be explained, using modern theories of wage bargaining?

3) How has the wedge developed in the Netherlands and in other OECD countries?

4) How can tax shifling on the labour market be explained, using existing theories of the influence of taxes on a market and using modern approaches to union behaviour?

5) To what extent do the specific characteristics of the Dutch labour market contribute to tax shifting? 


\subsection{Overview over this study}

\subsubsection{General overview}

This book consists of 10 chapters and can be divided in three parts. Each part contains a series of related studies. Part 1 , chapters 2-5, discusses questions 1 and 2. This part provides the reader first with information about the way wage bargaining takes place in the Netherlands. Second, it gives the reader insight into modern approaches to union behaviour and wage bargaining models, and third, pays attention to wage drift, another phenomenon in the Dutch labour relations. Finally the continuing struggle between centralization and decentralization that has characterized Dutch industrial relations for many years is discussed. The chapters 6-8 discuss the questions 3 and 4 . They focus on the role of taxes in market clearing models and in wage bargaining models and in the meantime the reader will become familiar with the major developments in the wedge. Finally, part III (chapter 9) discusses question 5: a multi-tier wage bargaining model for the Netherlands using the information that is gathered in the previous chapters. Table 1.1 summarizes the contents of this book.

Table 1.1 The contents of this study

\begin{tabular}{|c|c|}
\hline Chapter 1 & $\begin{array}{l}\text { Introduction: the framework of the problem that will be discussed and the } \\
\text { organization of the book }\end{array}$ \\
\hline Part I & Studies in wage formation - research questions 1,2 \\
\hline chapter 2 & $\begin{array}{l}\text { Wage formation in the Netherlands: bargaining, centralization and decentralization; } \\
\text { wage drift }\end{array}$ \\
\hline chapter 3 & Modern approaches to wage bargaining: right-to-manage and efficient bargaining \\
\hline chapter 4 & A bargaining approach to wage drift \\
\hline chapter 5 & $\begin{array}{l}\text { Centralization and decentralization: the continuous struggle in the Dutch labour } \\
\text { relations }\end{array}$ \\
\hline Part II & Taxes and wages - research questions 3,4 \\
\hline chapter 6 & The development of the wedge: a growing wedge and a changing composition \\
\hline chapter 7 & $\begin{array}{l}\text { Taxes and wages } \\
\text { Dalton's law I: market clearing models }\end{array}$ \\
\hline chapter 8 & $\begin{array}{l}\text { Taxes and wages } \\
\text { Dalton's Iaw II: bargaining models }\end{array}$ \\
\hline Part $\mathrm{DI}$ & $\begin{array}{l}\text { Taxes in a three-tier wage bargaining model: the case of the Netheriands - } \\
\text { research question } 5\end{array}$ \\
\hline chapter 9 & $\begin{array}{l}\text { A three-tier wage bargaining model for the Netherlands: bargaining, centralization } \\
\text { and decentralization, and tax shifting }\end{array}$ \\
\hline chapter 10 & Summary and Conclusions \\
\hline
\end{tabular}




\subsubsection{The chapters}

Chapter 2 discusses how wages are determined in the Netherlands during the period after 1945 and four conclusions can be drawn. First, although about less than $30 \%$ of the Dutch employees are member of a trade union, wage contracts cover about $70 \%$ of the Dutch employees. The reason for this discrepancy is that in the Netherlands the government has the means to declare a particular contract valid for all employers and employees working in the same sector. Union membership is not important in this respect. Second, despite the periodical attempts to reach a bargain at the central level, most contracts are concluded at the industry level. Moreover, the tendency to conclude contracts at industry or firm level is growing. Third, because the wages that are actually paid exceed the contract wage, there is wage drift in the Netherlands. Fourth, it seems that according to recent research results, the combined centralized and decentralized labour relations in the Netherlands can cause relatively moderate economic performance. In addition to these conclusions, chapter 2 points at three important issues that dominate the institutional features of Dutch labour relations (as far as wage formation is concerned): wage bargaining, wage drift and centralization or decentralization of wage bargaining. Chapters 3, 4 and 5 elaborate on these features by surveying theoretical developments and results of empirical research. Further, the applicability of this research for Dutch wage negotiations is discussed.

Since union-employer bargaining is so dominant in modern labour relations, chapter 3 elaborates on union motives and union behaviour. According to the modern approach of union-firm bargaining, parties can bargain about both wages and employment. If union utility depends also on employment, unions might be willing to engage in an efficient bargain. This chapter shows how results differ between the monopoly model, the right-to-manage model and the efficient bargain model. It can be concluded that the final result of the bargain between the union and the employers organization depends on the bargaining items. Finally, although the efficient bargain model has attractive characteristics, there are severe disadvantages in this model.

Chapter 2 concludes that the wage setting system in the Netherlands is characterized by the existence of two levels of negotiation and by the phenomenon of wage drift. Further, throughout the history of the Dutch labour relations the question whether negotiations must be centralized or not plays an important role. Chapters 4 and 5 expand these issues. Chapter 4 elaborates on wage drift, developing a two stage wage setting model, using the efficiency wage argument to explain wage drift. It can be concluded that as long as the contract wage differs from the optimum wage at the firm level, wage drift will occur. Using the efficiency wage framework enables to define the optimum for the firm in unambiguous way. Chapter 5 closes the first series of studies by discussing the centralization-decentralization issue. It starts developing 
with the help of simple game theory the major concepts. Next it analyses whether there is a relation between the level of wage bargaining and economic performance. It concludes that theoretical models point in the direction of a positive relation between centralized wage bargaining and wage moderation, but the strategic behaviour of the bargaining parties lowers the possibility of actually achieving wage moderation through central wage bargaining.

Taxes are the subject of the second series of studies (part II). Chapter 6 provides some abstracted facts about the magnitude and the development of the wedge, both for the Netherlands and for other OECD countries. Two conclusions can be drawn from this chapter. First, there is a severe measurement problem in measuring and comparing the wedge. This problem occurs not only in data at the level of the individual, but also in aggregate data. Second, the developments in modern welfare states (OECD countries) closely resemble each other. Since the second World War, growing taxes and contributions for social security have increased the wedge. There are, however, major differences between countries concerning the magnitude and the composition of the wedge.

For this study I am interested in three questions with regard to the existence of taxes/social security contributions on the labour market. These questions are derived from research question 4 . First, how do taxes influence equilibrium in the market? Second, how is the distribution of the economic burden of the tax determined? Third, how do taxes influence the results in wage bargaining models? Chapter 7 focuses on the first and second question and starts by analysing the effects of taxes on equilibrium price and equilibrium quantity in a competitive market and in particular in a competitive labour market. If economic agents focus on after-tax prices, the introduction of a tax causes a rise in prices and a decrease in the traded quantity (if the price elasticities of supply and demand are not equal to zero). Next, the distribution of the economic burden of the tax is analysed. This distribution is determined in competitive markets by the price elasticities of demand and supply. This well-known result is called Dalton's Law.

Chapter 8 analyses the incorporation of taxes in wage-bargaining models and focuses on the third question. After a theoretical analysis, the findings are applied to wage bargaining models that are used in empirical research to measure the effects of taxes on the labour market, both for the Netherlands and for some other OECD countries. These type of models mostly use aggregate data. Empirical results suggest that taxes have been shifted in the Netherlands during the period 1960-1980. This chapter ends with a discussion of the results of research on tax shifting on the labour market. It follows that the results of this kind of research are difficult to interpret. For example, unions can only influence contract wages, while total wages are subject of 
empirical testing. Hence, the development of the wages in these models cannot only be ascribed to union behaviour. Moreover, the little research that explicitly distinguishes between contract wages and wage drift points in the direction of a relation between tax shifting and wage drift instead of tax shifting and contract wages. Therefore in this thesis contract wages and wage drift are distinguished. It is concluded that in order to explain the shifting process, there is a need to improve the modelling of union behaviour and the description of union-firm bargaining. After these analyses, the question how the knowledge can be applied to the Dutch labour market, is left.

Chapter 9 (part III) presents the last study in which a model is developed that aims at capturing specific Dutch labour market characteristics. A wage-bargain model for the Netherlands is presented in order to be able to analyse tax shifting. This model introduces elements that have been neglected in research into tax shifting on the labour market. Three new aspects are developed. First, I explicitly deal with the difference between contract wages and wage drift. This implies that both union and individual behaviour with regard to wage bargaining are modelled. Therefore the model is a multi-tier wage bargaining model. Second, the assumption that unions do not care about the provision of public goods is abandoned. Therefore a utility function that includes value to public goods is used. Third, different preference functions and different bargaining models are used in the description of the various wage bargaining levels. It is concluded first that if unions value public goods, tax shifting is less prominent. Second, in this model shifting of employees' part of the wedge occurs at the level of the firm, while shifting of employers' taxes occurs at each wage bargaining level. The study ends with a summary of the main results of this research (chapter 10).

\subsection{Methodology}

When this research project started, results of empirical research relating wage changes to tax changes were studied first. After this investigation, two questions came up: first, do these models capture the characteristics of the Dutch labour relations and second, how do the results fit into existing tax shifting theories? I concluded that institutional features received little attention and that the relation between the empirical results and the theoretical foundation with respect to tax shifting is often rather weak. A nice example of this weakness can be found in Compaijen and Vijlbrief (1994). According to the results of their empirical analysis, a shift from employers' to employees' part of the wedge-burden creates employment because the wage will decrease. However, since their model is an equilibrium model, this is a strange result. For, a famous theorem in economics is the irrelevance of the side of the market that is taxed in an equilibrium context. This theorem basically states that if a market is functioning well, the change 
in wage costs, net wages and employment is independent of the side of the market that is taxed (this theorem holds both for partial and for general equilibrium, see Keller (1980), see also chapter 7 of this book). Further, in my view there is a conceptual problem when unions are held responsible for tax shifting results. The reason is that unions control only part of the wage rate, the contract wage. Since there is evidence that the relation between taxes and contract wages differs from the relation between taxes and labour costs, taxes might be shifted via wage drift (Kramer, (1979), Van Veen (1987), see also Drimmelen et. al. (1995)). If this is the case, the conclusion that unions cause a tax-wage spiral is preliminary. The questions that arose, motivated to analyse in more detail (than I had planned at the start) theories of wage bargaining and tax shifting instead of adding another empirical model. Therefore this study is largely theoretical in character. I have tried to "sharpen" these models by discussing the theoretical framework in more detail. Hence, as far as empirical results are discussed, I lean heavily on the results of empirical research by colleagues. My own empirical contributions to the literature can be found throughout this study. Delsen and Van Veen (1992) and Cörvers and Van Veen (1995) link up with chapter 5; Van Veen and Van der Veen (1987) and Muysken and Van Veen (1996b) are incorporated in chapter 8. Further results can be found in chapter 6 , in the data sampling.

Finally, note that throughout this study, a partial equilibrium approach is used. This stems from the fact that this research links up closely with existing (income) tax shifting research which is mainly based on bargaining models and analyses of the labour market in isolation.

\subsection{Relation to other work in this field}

There has been a lot of research in the field of wage bargaining and wage determination and tax shifting. From this wide area, three approaches in the literature are especially interesting for this study. First, the literature that discusses wage bargaining. Since the famous article by McDonald and Solow (1981) a huge amount of literature has appeared that discusses and refines wage bargaining models. This study elaborates, reviews and comments on these types of models in chapter 3 and expand on them in chapters 8 and 9 . Second, the Dutch labour relations are characterized by discussions at a central level and industry negotiations. Further there has been a lot of discussion about the desired level of wage bargaining. Therefore, the literature on centralization versus decentralization in wage bargaining (among others Abraham (1987; 1989) Calmfors and Driffill (1988), Layard (1989), Mulder (1989), Jacobs and Janssen (1990), Soskice (1990), Wilke (1991), Calmfors (1993), Cörvers and Van Veen $(1992 ; 1995))$ is of relevance. This literature is reviewed in chapter 5 and focuses 
on the question whether a system of completely centralized wage setting leads to different results (i.e. development in the wages) than a system of decentralized wage setting. Closely related to this topic are problems regarding wage drift (Holmlund (1986), Moene (1988), Holden (1988)). Third; I draw heavily on literature dealing with problems of payroll tax shifting. Theoretical insights from public finance theory (Dalton (1954), Musgrave and Musgrave (1987), Stiglitz (1988)), theoretical research (Keller (1980)) and empirical research (Brandsma and Van der Windt (1983), Knoester (1983,1988), Knoester and Van der Windt $(1985,1987)$, Van Veen and Van der Veen (1987), Brunia and Kuper(1990)) will be used. Empirical research concerning tax shifting is numerous. Although the conclusions differ, in general it can be concluded that shifting behaviour does exist. This means that a positive relation between the development in taxes and wages can be found. Nevertheless, I have some problems with the relation between the empirical research and the theoretical framework that has been used for the research. For example, it has been shown that if the development of contract wages is analysed, the relation between taxes and wages is less clear than if total wages are used. In this study I focus on the theoretical foundation for tax shifting. What is added to this literature? In my view four elements.

First, theoretical foundations of the empirical literature on tax shifting need improvement. For example, although in most wage equations wages are positively correlated with taxes, it is not clear how the wage-tax spiral really works. The contribution on this point aims at modelling and describing the mechanism behind these results. In this description I explicitly use characteristics of the Dutch labour market. To give an example, neither complete centralization, nor complete decentralization is suitable as a description of the Dutch labour market. As I conclude in chapter 2, the Dutch labour market system is much more complex. There are central negotiations; resulting in guidelines. These guidelines are not enforceable, however, and this leaves the question about the relevance of central negotiations especially since most labour contracts are concluded at the level of the industry. Hence, in order to make the models suitable for the Netherlands I have to use them $:$ a different framework. This is elaborated in chapter 9 . Second, I discuss carefuh $y$ and expand a widely used model to explain wage drift. This approach, the incorporation of efficiency wages in such a model, is a relatively new approach (see chapter 4 ). Third, since the wedge plays an important role in this study I explicitly pay much attention to the measurement of the wedge (see $\mathrm{Ch}$ 6). In studying the available empirical results, I was struck by the lack of information about the way the wedge was measured. Fourth, I carefully consider the role of taxes in both market and bargaining models (see Ch. 7, 8 and 9). Especially, the question concerning the symmetry of the effects of employerst 
and employees' taxes is an often discussed topic. To my knowledge, this question was not yet analysed in bargaining models in the way 1 do in chapter 8 . 


\section{PART I STUDIES IN WAGE FORMATION}

Part I consists of chapters 2-5. In chapter 2 it starts with a description of the process of wage formation in the Netherlands. Three elements return repeatedly in the description. First, wages result from a bargaining process between unions and employers' organizations. Second, for a variety of reasons, earned wages differ from contract wages. Third, as in other European countries, in the Netherlands there is an ongoing debate about the extent of coordination in the process of wage bargaining. These three elements are elaborated in chapters 3,4 and 5. Chapter 3 elaborates on wage bargaining, chapter 4 discusses a model of wage drift and chapter 5 expands centralization and decentralization in wage bargaining. 


\section{Chapter 2}

\section{WAGE FORMATION IN THE NETHERLANDS}

This chapter discusses wage setting in the Netherlands. Since between 1945 and 1964 the famous guided wage policy was implemented, while after 1964 free negotiations have been the dominating picture, the postwar period is divided into two periods, 1945 1964 and $1965-1995$. The focus is on two topics first, the organization of the wage bar gaining process and second, the difference between contract wages and actual earned wages, ie. wage drift.

Three conclusions are drawn. First there is a large difference between union membership and union coverage in the Netherlands: although about less than $30 \%$ of the Dutch employees are members of a trade union, wage contraets cover about $70 \%$ of the Dutch employees. The reason is that the Duteh government has the means to declare a particular contract valid for all employees working in the same sector, whether or not they are members of a union. Second, the Duteh labouir relations are characterized by a continuous struggle between centralization and decentralization: however, despite the petiodic attempts to reach a bargain at the central level, most contracts are cioncluded at the industry level. Moreover, the tendency to conclude contracts at industry or firm level is growing. Third, because the wages that are actually paid exceed the contract wage, There is wage drift in the Netherlands.

\subsection{Introduction}

This chapter discusses the institutional aspects of wage formation in the Netherlands. The chapter starts with a description of the process of wage formation and wage policy in the Netherlands after 1945. Such a description is useful in making the position of the various parties during the wage negotiations clear. Special attention is paid to the relation between the centralized and the decentralized level because in my view this is an important characteristic of Western-European, and in particular Dutch, labour relations. Further I pay attention to the phenomenon of wage drift.

The chapter is organized as follows. With regard to wage policy in the Netherlands, the postwar period can be divided into two periods. The period 1945-1964 was characterized by a policy of wage controls. In section 2.2 I give a description of this policy. In the period after 1964 the systematic policy of wage controls was abandoned in favour of a policy of ad hoc measures. Section 2.3 deals with the post-1964 period. During the period of the guided wage policy, it became clear that wage drift grew. Incorporation of elements of wage drift in the contract wages was one of the main causes that the policy of wage controls had to come to an end. In section 2.4 I discuss 
the relation between contract wages and wage drift. Section 2.5 evaluates Dutch labour relations and closes this chapter with concluding remarks.

\subsection{The period 1945-1964: a policy of guided wages}

\subsubsection{Organization of the guided wage policy}

After world war II the need for a quick recovery in the Dutch economy led to a consensus about the development of wages and prices. It was agreed upon that neither wages nor prices should develop at a fast rate. In order to implement this consensus, a policy of wage controls was developed.

Dutch wage policy in this period was rather untransparent. This was due to ambiguity in the thoughts about the role of the various parties involved in the wage negotiations. The discussion focused on the level of centralization and coordination in the wage policy. Should policy come from discussions between government and representatives of central organizations of employees and employers or, alternatively, should government discuss with unions and employers at the level of the industry or the firm? Finally it was decided to mix both ways. Bargaining about collective agreements at the level of the industry/firm ${ }^{2}$ returned. However, parties were obliged to let the bargaining result be approved by "the government". For this approval, the Board of Arbitration (College van Rijksbemiddelaars) was formed.

The wage setting process started with advice from central organizations of employers and employees, united in the Foundation of Labour ${ }^{3}$, to the government with regard to the development of wages (in the next section the wage norms are discussed). This resulted in guidelines for wage developments. ${ }^{4}$ In the next stage bargaining at a decen-

1 Notwithstanding this, the best description of the Dutch wage policy during the postwar period can be found in a book by an American author, Windmuller (1969). See also Windmuller and De Galan (1977), Fase (1980), and Van Hulst (1984b), for a description and an analysis of the Dutch guided wage policy.

2 In contrast to the USA, bargaining about labour conditions at the firm level is rather uncommon in the Netherlands. Only in large-scale firms (e.g. SHELL, Unilever, Phillips) does bargaining about a collective agreement for the firm occur.

3 The Foundation of Labour is a private organization where represientatives of central organizations of employers and employees discuss labour relations.

4 The guidelines were sent to the Board of Arbitration which used them in their judgement about the collective agreements. About the status of these guidelines, Fase concludes that they were meant primarily for the Board of Arbitration, not for the bargaining parties. However, deviation from 
tralized level took place. The result of the bargaining ${ }^{5}$ was sent to the Board of Arbitration which advised the government about these results. However, the Board consulted the Foundation of Labour beforehand. Although the Board of Arbitration could deviate from the advice of the Foundation of Labour, the advice to the government followed in most cases that of the Foundation. Finally, the collective agreement was made binding for an industry. In 1950 the position of the Foundation of Labour was taken over by the Social Economic Council: in this council employers, employees and independent members are equally represented. Figure 2.1 summarizes how wage policy was implemented in the Netherlands.

Figure 2.1 Guided wage policy in the Netherlands

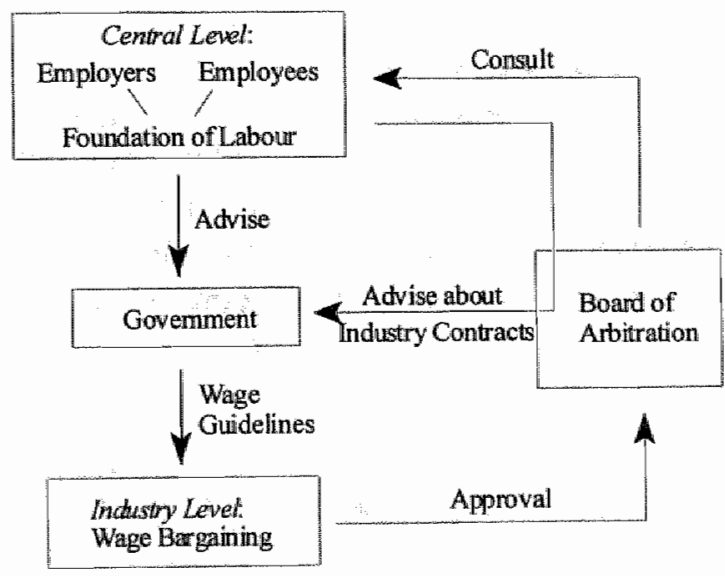

Note the central role of the Board of Arbitration. Only after approval of the Board, could the agreements be binding. The members of this Board were appointed, suspended and dismissed by the minister of Social Affairs. The Board was independent in the sense that decisions could not be overruled by the minister, although the minister could give directives to the Board. It is remarkable to note that notwithstanding the wage

the guidelines would make the approval of the collectiwe agreement unlikely, see Fase (1980), Ch. 3 .

5 Indeed, industry-level bargaining was not difficult in this period (cf. Windmuller and De Galan (1977), part 2, ch. 1). Because the development of wage costs was known to the parties, bargaining was about other elements of a collective agreement, such as labour conditions and labour legislation. 
policy, industry-level collective agreements retained an important place in the labour relations. The reason was that in this way government succeeded in involving labour market parties at different levells in economic policy. It should be noted that employers and employees indeed felt co-responsible for economic development.

As a consequence of the wage policy, wage developments in the Netherlands were moderate, especially in comparison with developments outside the Netherlands (see also 2.2.2). Further, exports, income and employment rose. ${ }^{6}$ This resulted in 1959 in changing opinions about wage-guidelines. A cry for freedom in wage negotiations followed the favourable economic developments. Both the wish for more decentralization and freedom to incorporate various industry-specific characteristics in wage negotiations were elements of this demand. This resulted in wage guidelines based on developments in real productivity per industry instead of some kind of averaged macro-productivity that was used in the foregoing period. However, fear of inflation led to the role of the Board of Arbitration remaining the same. Note that this resulted not in freedom of industry-level bargaining, but in incorporation of industry-specific characteristics in a kind of guided wage policy.

In spite of the new flexibility, employers faced great difficulties in attracting employees. Paying more than the contract wages became inevitable (see 2.2.3). After discussion in the Social Economic Council, a new policy was developed. As before, the new system was characterized by a combination of decentralization and government control. Broadly speaking, the Social Economic Council advised a percentage increase in wages to the government. If government agreed, the Foundation of Labour had to convince the separate unions and employers' organizations that collective agreements should stay within the wage norm. Euphemistically, one could call this the internal coordination function of the encompassing federations of unions and of employers' organizations. In addition all agreements were subject to approval or rejection by the Foundation of Labour. About this policy Windmuller and De Galan conclude (vol. 2, p. 33 , translation by the author):

\section{"The amended law contributed to the establishment of an exceptionally complex system of wage determination, far more complex than its prede- cessor." and "The final construction became a miraculous mix of paradoxes, subtleties, escape clauses and provisions for exceptional circumstances - a consultation procedure unique in the world"}

6 Of course, these developments were not only due to the wage policy. A general boom characterized the postwar years of rebuilding the economy in most European countries. The point I want to stress here is that the relative position of the Netherlands (market share of their exports for example) improved. 
The main difficulty in the new system was that the Foundation of Labour could not shift the responsibility for undesired wage increases to an independent body, such as the Board of Arbitration, as before. When the labour market is tight and productivity and profits are growing, one cannot expect the unions to abstain from demanding wage increases. In reality, the gap between the wage norms in collective agreements and the wages that were paid grew, undermining the credibility of the wage policy. Finally, in 1964 the system collapsed.

\subsubsection{Implementation of guided wage policy}

An important question in a period of guided wage policy concerns the permitted wage increase. Not only the magnitude but also the question whether the wage increase should be uniform or not must be discussed. At the start of the guided wage policy, during the period 1945-1954, the aim was to keep real wages constant: besides, nominal wage increases were uniform; there was no room for industry-specific adjustments.

From 1954-1959 the aim of the wage policy was to keep the share of labour income in national product constant: nominal wages increased by the rise in prices plus the rise in (macroeconomic) productivity. ${ }^{7}$ Tightening of the labour market, however, forced the possibility of exceptions in case specific developments in an industry demanded it. Finally, during 1959-1963/4 wage increases followed increases in prices and increases in industry-productivity. The introduction of industry-productivity led to

7 This share is defined as total labour income (both from employees and from labour incone assigned to self-employed), W.L, divided by nominal national income, py. $y$. Thus the share can be written as (W.L/py.y). If this is expressed in terms of percentage changes then $(W+L)-(p y-y)$, (where italics denote the percentage change), is the change in labour share. This equals $(W-p y)-(y-L)$. Thus if the rise in real wage costs exceeds the rise in labour productivity either labour share in income increases or the share of other income (mainly consisting of profits) decreases. It should be noted, however, that the relation between real labour costs and labour productiwity matters. A change in labour costs in itself has no direct meaning in this context. The same is true for a change in labour share. This share can change while labour costs remain constant. A rise in prices of raw materials for example may lead to a decrease of py.y and thus a rise in labour share (assuming the ceteris paribus condition). Available evidence about a profit squeeze in the Netherlands is scarce. From Keus (1980 and 1981), however, it can be concluded that the ratio of profits to net domestic product decreased from $18 \%$ to $4 \%$ during the period 1960-1978. Half of this increase can be ascribed to the increase in social security contributions by employees and employers. The other half is due to an increase in the interest rate.

This sum of price increases plus productivity increases is called the "wage room" in the Netherlands and is still an important, although heavily discussed wage guideline in the negotiations between the unions and the employerst organizations, see Pen (1991), Hartog (1991) and Den Butter (1991). 
differentiation in wage developments between industries. Table 2.1 summarizes the results of the implementation for the period $1948-1962 .^{8}$

Table 2.1 Wage norms and increase in wage cost per employee $1948-1962$.

\begin{tabular}{|l|l|l|l|}
\hline Period & Wage norm & Wage cost & Difference \\
\hline $1948 / 1953$ & $4.5 \% *$ & $6.2 \%$ & $1.7 \%$ \\
\hline $1954 / 1958$ & $6.5 \% * *$ & $8.4 \%$ & $1.9 \%$ \\
\hline $1959 / 1962$ & $4.8 \% * *$ & $5.9 \%$ & $1.1 \%$ \\
\hline
\end{tabular}

Source: Van Hulst (1984b), Tables 8.3, 8.5 and 8.7.

* during this period the wage norm was: increase in nominal wages = increase in consumer prices.

** during this period the wage norm was: increase in nominal wages $=$ increase in labour productivity plus increase in consumer prices.

From Table $2.1 \mathrm{I}$ conclude that despite the amount of monitoring, wage costs have exceeded the wage norms. The main reason was the tight labour market that caused excess payments.

In order to illustrate the break that occurred in 1963/1964, note that wages increased by $9.0 \%(1963)$ and $14.9 \%$ (1964).

To summarize, the aim of the policy of guided wages was to facilitate the period of economic recovery after World War II. This policy was executed by way of uniform wage norms aiming at constant real wages/constant share of labour income in total income.

\subsubsection{Guided wage policy and market forces}

Wage policy generated some side goals such as full employment and served price and income policies. Stabilization of prices has always been an important goal in a vulnerable economy such as the Dutch. Wage policy became the instrument to reach this goal, hence implicitly prices are assumed to be set as a mark-up on wages. In fact, wage policy was subordinate to price policy. Besides, uniform wage guidelines preserved the relative wage structure (incomes policy). Relatively moderate inflation and low levels of unemployment were indeed the main results of the wage policy. This is illustrated in Table 2.2 where some stylized facts for the Dutch economy concerning

8 The years $1945-47$ are omitted because the figures for this period are highly unreliable. Wage norms and wage costs are measured as the percentage increase per employee per year. 
the development of competitive position, unemployment, economic growth and wage drift (we discuss wage drift in more detail in section 2.4) for selected periods are presented. The moderate wage developments caused moderate price developments, thus favouring the conditions for an improvement in market share for Dutch exports. Hence employment increased and economic growth fostered. Apart from these developments, profits grew. It should be noticed that developments differed from sector to sector.

Table 2.2 Stylized facts about the Dutch economy in the period 1950-1968

\begin{tabular}{||l|l|l|l|l|}
\hline Period & Market share & Unemployment & $\begin{array}{l}\text { Economic } \\
\text { growth }\end{array}$ & Wage drift \\
\hline $1948 / 1953$ & 4.6 & 3.0 & 4.8 & 1.6 \\
\hline $1954 / 1958$ & 0.95 & 2.0 & 4.1 & 1.6 \\
\hline $1959 / 1963$ & -0.81 & 1.4 & 5.3 & 2.5 \\
\hline $1964 / 1968$ & 1.28 & 1.5 & 6.3 & -0.2 \\
\hline
\end{tabular}

\section{Source:}

Centraal Plan Bureau, Centraal economisch plan, 1973, appendix C1 and C2. Figures are average percentage changes, except the unemployment figure which gives the average level. Unemployment for the period 1948-1953: Centraal Bureau voor de Statistiek, Negentig jaren statistiek in tijdreeksen, 1989. The unemployment figure from .1948-1953 is that of 1952 .

Market share is measured as the difference between the percentage development in Dutch exports less the percentage development in world imports (real terms, CEP 1973, p. 102). Economic growth is measured as average percentage increase in real national income.

Wage drift figures: 1948-1958, Van Hulst (1984b), Table 8.4 and 8.6; 1959-1963, Windmuller and De Galan (1977), vol. 2, p. J05; 1964-1968, Centraal Bureau voor de Statistiek, Indexcijfers van Regelingslonen, 1975, Aanhangsel 1, p. 31. Wage drift is measured as the difference between the percentage development of actual wages and the percentage development of contract wages.

It is not surprising that in such an economic environment a policy of centrally determined wages based upon wage moderation is hard to continue and an increase in wage drift is a first signal. In these circumstances a coordination problem for the central unions arose. To carry out a policy of wage determination and wage moderation at a central level asks a lot of the ability of the unions to justify and even defend this policy to its members. If economic developments in general and developments per sector in particular give rise to higher wage claims, this task is more difficult. Further, developments per sector asked for differences in wage developments. This was permitted under the regime of the guided wage policy (wage developments were in line 
with productivity developments in industries), but these differences were in fact not accepted by all unions. This tension between uniformity and freedom, between coordination and differentiation, is, according to Fase, one of the main causes of the failure of the policy of guided wages. ${ }^{9}$ The result of this tension was a general increase in wages.

Thus, because in the early sixties the Dutch competitive position deteriorated, wage policy was most necessary but its implementation caused severe problems. Centralized wage policy has proved to be successful in a situation in which the common interest is obvious for the participating parties. If this condition is not fulfilled, coordination problems show up.

\subsection{The period after 1964}

\subsubsection{The organization of wage bargaining}

In 1963 and 1964 the difference between the wage norms and the wage costs increased. The first answer to these developments was an increase in the wage norms. Second, in order to escape from the large wage increases, a tendency occurred to conclude long-term contracts ( 2 or 3 years) which enabled also further tailor-made clauses. And from 1964 onwards, collective agreements have been reached under a regime of free bargaining. Note that the end of the guided wage policy was not sudden, but in fact took place during the period 1959-1964.

In Dutch labour relations, this means basically that from 1964 bargaining takes place at the level of the industry between industry unions and (representatives of) employers. This aspect of the labour relations has been organized in the "Loonwet" (Wage Law) since 1970. Three elements of this law are worth mentioning:

- there is no longer an institution to approve collective agreements between parties

- collective agreements must be announced to the department of social affairs and employment

- despite the freedom in collective bargaining, the government is allowed to intervene in the negotiations by making directives that last for a maximum of 6 months.

Further, I must add that in the Dutch process of wage bargaining, collective extension plays an important role. This implies that collective agreements are made legally binding for all employers and employees within an industry, whether or not they are 
member of their respective industry organization. Although collective extension is not automatically reached (it must be requested from the Minister of Social Affairs and Employment), contracts are often extended and this can be seen as a way to coordinate wage developments within an industry. However, in Dutch labour relations there is still a role for a supra-industry level, which I shall call the central level. In the next sections I discuss in more detail the relation between the central level and the industry level in the process of wage bargaining. I start with a description of the parties that participate in the negotiations.

\subsubsection{The players ${ }^{10}$}

Both industry unions and federations of unions function in Dutch labour relations. The same is true for the employers' organizations. There are no firm-specific organizations.

The industry unions are united in two umbrella organizations, the CNV (Christian Union) and the FNV (Socialist Union). In addition to these organizations, there is a third central organization for employees, the MHP that is meant to organize welleducated white collar workers from all sectors. At the end of 1989 about 18 organizations were linked to the FNV and the CNV, and three organizations were connected to the MHP (Albeda and Dercksen, 1994, ch. 2).

On the employers side there is a similar kind of structure. One can distinguish seven central organizations: first the encompassing organizations for the industry, trade and services sector, the NCW (Christian organization) and the VNO (Non-Christian). Second, there are two organizations for the retail trade, the KNOV (Non-Christian) and the NCOV (Christian). Third, in the agricultural sector there are three organizations, the KNLC (Non-religious), the KNBTB (Catholic) and the NCBTB (Christian). ${ }^{11}$ Note that membership of these employers' organizations varies in nature: members are found among firms (e.g. 400 VNO members are firms), among industry (employers') unions and among managers. Note further that in contrast to employees, employers (i.e. firms) are often affiliated to more than one central organization.

The position of the encompassing organizations in the wage negotiations is not clear since there is no direct bargaining between these organizations. The importance of the encompassing organizations is twofold. First, these organizations have seats on a number of advisory boards in the field of labour market policies and economic policy in general such as the Foundation of Labour and the Social Economic Council.

10 In this section I use a number of abbreviations. These will be explained in Appendix 2.

11 Of course, this picture is broad. Note for example that there is a small number of employees' unions that are not affiliated to one of the three encompassing organizations. "They represent, howewer, only a minority of unionized labour (about 20\%). 
Second, if the encompassing organizations reach an explicit or implicit agreement about the development of wages, their major task is to coordinate the industry-wide negotiations. If no agreement is reached, they only act as a kind of service organization for their members (the affiliated unions/firms).

\subsubsection{The role of the central level in Dutch wage bargaining}

If central organizations of employers and employees agree about the desirable development of wages and employment, they can record this agreement in a treaty, a so-called social or central agreement. This kind of contract stems from the period of wage guidelines.

After this period of strong interference by the government it became difficult to accept complete freedom in the negotiations. Parties felt that some coordination was necessary because of the importance of the development of the wages in the Dutch economy. Thus, since 1964 employers and employees discuss the possibilities of a central agreement. The government is sometimes an active partner, sometimes only an interested spectator. In fact whereas responsibilities for economic development were shared during the period of the guided wage policy, they were separated in the period thereafter. Employers and employees are responsible for the labour relations, government for economic development. ${ }^{12}$ However, to complete the picture I need to mention here that government was not always a passive spectator: e.g. a wage law and several wage measures were initiated by the government. Table 2.3 surveys broadly the wage determination process in the Netherlands during the period 1964-1995.

In practice, parties did not succeed in reaching a central agreement very often. Between 1964 and 1995 only four contracts were signed: in 1972, 1982, 1992 and 1993. Note that the agreement of 1964 was not a real central agreement since it was only meant to try to save the system of central wage bargaining. By agreeing about an unprecendentedly high wage increase, the federations expected that they could prevent a breakdown of the policy of guided wages. This strategy failed, however. In 1989 parties reached a common agreement for policy. Note further that in the Netherlands the conclusion of a central agreement does not imply that there are no industry negotiations.

12 cf. Fase, $\mathrm{Ch} .8$. Although the concept of "economic development" might be vague, I mean here the realisation of the five goals as were formulated by the Social Economic Council in 1956. They are sufficient economic growth, stabilization of prices, full employment, balance of payments equilibrium, fair division of income. In the sixties a sixth goal was added, care concerning environmental pollution. In Windmuller and De Galan the results of the wage policy are ewaluated along the lines of the five goals, see their chapter 9 in part II. 
Table 2.3 Wage determination in the Netherlands 1964-1995

\begin{tabular}{|c|c|c|}
\hline YEAR & RESULTS & COMMENTS \\
\hline 1964 & $\begin{array}{l}\text { Agreement on a nationwide wage } \\
\text { increase of } 10 \%\end{array}$ & $\begin{array}{l}\text { Actual wage increase of } 15 \% \text {, end of the } \\
\text { guided wage policy. }\end{array}$ \\
\hline 1965 & $\begin{array}{l}\text { Government proposal: wage increase of } \\
5 \%\end{array}$ & $\begin{array}{l}\text { Negotiations at the industry level resulted in } \\
\text { higher wage increases }\end{array}$ \\
\hline $\begin{array}{l}1966- \\
1967\end{array}$ & $\begin{array}{l}\text { Wage norm determined by the govern- } \\
\text { ment: maximum increase of } 6 \text { or } 7 \% \\
\text { (1966) and } 4 \% \text { (1967). }\end{array}$ & $\begin{array}{l}\text { During this year, unemployment increased. } \\
\text { No problems in maintaining the norms. }\end{array}$ \\
\hline $\begin{array}{l}1968- \\
1972\end{array}$ & $\begin{array}{l}\text { No central agreements: collective agree- } \\
\text { ments at the industry level }\end{array}$ & $\begin{array}{l}\text { Now and then the govemment intervened in } \\
\text { the wage negotiations }\end{array}$ \\
\hline 1972 & First Central Agreement & $\begin{array}{l}\text { First oil crisis; wage moderation: real wage } \\
\text { increase lower than productivity increase. }\end{array}$ \\
\hline 1974 & $\begin{array}{l}\text { Government directives on the wage } \\
\text { increases }\end{array}$ & Temporary returin to the guided wage policy \\
\hline 1975 & Industry negotiations & $\begin{array}{l}\text { Margins for wage increases determined at the } \\
\text { central level }\end{array}$ \\
\hline $\begin{array}{l}1976- \\
1981\end{array}$ & $\begin{array}{l}\text { Government takes measures on the } \\
\text { wage increases }\end{array}$ & $\begin{array}{l}\text { Various attempts to reach a central agreement } \\
\text { failed }\end{array}$ \\
\hline 1982 & $\begin{array}{l}\text { Second Central Agreement: the } \\
\text { Wassenaar Accord }\end{array}$ & $\begin{array}{l}\text { Reconmendation to moderate wages in } \\
\text { exchange for increase in employment }\end{array}$ \\
\hline $\begin{array}{l}1983- \\
1995\end{array}$ & $\begin{array}{l}\text { According to the Wassenaar Accord: no } \\
\text { more government intervention in } \\
\text { collective bargaining }\end{array}$ & \\
\hline $\begin{array}{l}1983- \\
1988\end{array}$ & $\begin{array}{l}\text { No government intervention in the wage } \\
\text { negotiations } \\
\text { No central agreements } \\
\text { Bargaining at the industry level }\end{array}$ & Moderate wage developments \\
\hline 1989 & Common Agreenent for Policy (CAP) ${ }^{14}$ & $\begin{array}{l}\text { Recommendations concerning schooling of } \\
\text { unemployed and increase in employment. }\end{array}$ \\
\hline $\begin{array}{l}1990- \\
1991\end{array}$ & Industry negotiations & $\begin{array}{l}\text { working-out of the recommendations of the } \\
\text { CAP }\end{array}$ \\
\hline 1992 & Third Central Agreement & Voluntary wage moderation \\
\hline 1993 & Fourth Central Agreement & Voluntary wage moderation \\
\hline 1994 & stry negotiations & \\
\hline
\end{tabular}

Solurces: Windmuller and De Galan (1977), vol, 2; Albeda and Dercksen (1994), Van Drimmelen, van Hulst and De Kam (1995); Stichting van de Arbeid (1982, 1992, 1993 - texts of the Central Agrcements).

13 Note that apart from the recommendation to solve the unemployment problem vila increasing cost-neutral efforts to distribute the amount of labour more equally, the Wassenaar Accord became famous in Dutch labour relations because it also explicitly reconfirmed the principle that wage bargaining is at the industry level and without government intervention.

14 In Dutch this is the "Gemeenschappelijk Beleidskader" (GBK). This was an agreement between confederations of unions, employers and the government that resulted in recommendations for the bargaining parties at the industry level (SER 92/15, Albeda and Van Veen, 1990). 
On the contrary, a central agreement is always followed by industry bargaining. This is explicitly stated in the so-called "Wassenaar Accord", concluded in 1982, which is among the central agreements best known. In this agreement, concluded after a period of rather frequent government intervention in the wages, parties explicitly agreed that negotiations must take place at the level of the industry, in complete freedom (i.e. without government intervention).

Over against that, the parties commit themselves to inform the government periodically about the developments of these negotiations. This Accord really proved to be a breakthrough: first it was an explicit statement against further government intervention and second, it stressed the importance of the industry level in the negotiations. From Table 2.3 it is clear that the ideas from the Wassenaar Accord have had their impact, since from 1982 there has been no direct government intervention in wages. This does not mean however, that government does not keep a keen eye on the collective agreements. In the summer of 1993, the minister of social affairs and employment has threatened to intervene in the wage negotiations by imposing a wage freeze. The government feared too high wage increases. Referring to the Wassenaar Accord, the Social Economic Council advised against such a measure. Nevertheless it is assumed that the Central Agreement of 1993 was concluded under the pressure of the intended wage measures by the government (Van Drimmelen et al. 1995).

Since there is no real central bargaining in the Netherlands, one may wonder about the effects of the existence of central organizations (with respect to their influence on industry negotiations) and the effects of the existence of some kind of central agreement. It is clear from Table 2.3 that tangible results are hardly ever reached. The consultations result in "intentions" and "frameworks" that can or must be used by the industry unions in their negotiations. What, then, is the impact of the result of the central consultations? The clearest answer is that the precise impact is unclear. Since no concrete agreements are reached, it is difficult to monitor whether the central consultations do have any impact. Elsewhere, I have argued that the impact of central consultations will increase if more concrete agreements are made (Albeda and Van Veen, 1990). In any case, the results of the discussions at the central level serve as a sort of input in the industry/firm wage bargaining. Simple measurement techniques do, however, indicate an influence. This is clearly demonstrated in the report evaluating the Common Agreement for Policy (CAP) of 1989 (Dienst Collectieve Arbeidsvoorwaarden, 1992). This report investigates whether agreements that have been concluded at the central level have been translated into collective labour agreements (CAOs, both at firm level and industry level) during the period 1989-1992. For this evaluation, $177 \mathrm{CAOs}$ are taken into account, covering $95 \%$ of the total number of workers covered by CAOs. From the report it can be concluded that the number of 
agreements in CAOs concerning schooling and employment increased from 187 in 1989 to 372 in 1992 . The majority of these agreements concern schooling and employ* ment plans. Note that most of the increase took place from 1989 to 1990. This is in accordance with the intentions of the CAP. Further, the SER concludes that the accord of 1982 has had "a structural influence on the Dutch labour relations during the last decade". And "the accord has contributed to a period of wage moderation, resulting in an annual decrease of real wage costs by about 1.2\% during the period 1984-1990 and has consequently increased employment by about 250,000 persons" (SER 92/15, p. 103). Finally, in the same report the SER concludes with respect to the accord of 1989 that "the available data suggest that especially the policy recommendations from the accord of 1989 are to an increasing extent translated into industries and firms" (SER 92/15, p. 167).

In many years, however, collective agreements could not be based on a central agreement. Does this mean that parties could not reach a consensus as in the period of the wage policy? Certainly not and two explanations for the scarcity of the central agreements can be given. First, although no explicit contracts were signed it is possible that implicit contracts were agreed upon. ${ }^{15}$ If parties agree about desirable developments but do not want to settle this formally, an implicit contract exists. The federation of unions/employers organizations then tries to translate this broad consensus into the negotiations, via persuasion of their affiliates. This explanation gives rise to a difficulty: from their very nature the existence of implicit contracts cannot be shown. One can only derive this explanation from the observed relative labour peace and from the fact that the Dutch labour unions are characterized as "responsible unions". ${ }^{16}$ Second, economic conditions might have hampered the realization of the central agreement. In the sixties, economic growth permitted both increasing wages and new kinds of social benefits. Besides, the labour market was tight. Under these circumstances both labour unions and employers' organizations might resist explicit contracts. In the seventies, especially from 1973, the conditions changed. Unemployment grew (slowly until 1979/1980, then at a faster pace until 1985/1986) and economic growth fell; the oil crises in 1973 and 1979 caused a deterioration in the terms of trade. In this period

is Albeda prefers the term "quasi-contract"; a kind of agreement which influences the results in decentralized bargaining. See Albeda (1990).

16 cf Windmuller and De Galan, II, Ch. 11. Among the European countries, the Netherlands is a country with a small number of days lost because of strikes. Recently, the chairman of the VNO, Rinnooy Kan, has confirmed in an interview that unions in the Netherlands still are "responsible unions" (Het Financieele Dagblad, 11/13 mei 1996). 
unions pressed for employment arrangements in a central agreement. However, employers resisted this pressure and refused to make explicit agreements on employment.

The major economic developments in this period are summarized in Table 2.4 . Of course (see footnote 6), it is not argued that the results of table 2.4 can be attributed to the freedom in wage bargaining. The results are presented to illustrate the Dutch economic environment in the $1970 \mathrm{~s}$, the 1980 s and the early $90 \mathrm{~s}$.

Table 2.4 Some key facts about the Dutch economy in the period 1964-1995.

\begin{tabular}{|l|r|r|l|r||}
\hline \hline Period & Market share & Unemployment & $\begin{array}{l}\text { Economic } \\
\text { growth }\end{array}$ & \multicolumn{2}{|l|}{$\begin{array}{l}\text { Wage } \\
\text { increase }\end{array}$} \\
\hline $1964 / 1968$ & 1.28 & 1.5 & 6.3 & 10.9 \\
\hline $1969 / 1973$ & 3.14 & 2.1 & 5.2 & 13.6 \\
\hline $1974 / 1978$ & 0.7 & 5.9 & 1.9 & 10.7 \\
\hline $1979 / 1983$ & 1.4 & 11.0 & 0.3 & 5.3 \\
\hline $1984 / 1988$ & 0.62 & 10.0 & 2.4 & 1.7 \\
\hline $1989 / 1995$ & -0.15 & 7.0 & 2.9 & 2.9 \\
\hline
\end{tabular}

See Table 2.2 for the definitions of the figures. From 1974 to 1983 , market share is measured as the percentage change in exports minus the percentage change in competitive exports (real terms). From 1984 market share is measured as the percentage change in exports minus the percentage change in the relevant world trade.

Source: Centraal Plan Bureau, Centraal economisch plan, 1979,1989, bijlage Cl and C2; Macroeconomisohe Verkenning 1996, bijlage A4.

Strong economic growth continued in the period 1964-1973 and the development of the volume of Dutch exports exceeded that of its competitors. Wage increases of more than $10 \%$ were realized. Unemployment increased slowly: in the period $1964 / 1966$ unemployment figures did not reach $2 \%$, from 1967 until 1971 levels of about $2 \%$ were reached and from 1972 levels of $3 \%$ or more was the unemployment picture. Although explanations for the development of unemployment are numerous, rising labour costs is seen in the Netherlands as an important factor contributing to this phenomenon. For example, in the macro-economic model of the central planning bureau that was used in the Netherlands between 1970 and 1980, production capacity consists of various vintages of capital. The newer the vintage, the less labour is needed in production because of embodied labour-saving technical progress. Hence, newer vinta- 
ges represent a higher labour productivity. It follows that an increase in real labour costs that exceeds the increase in labour productivity causes accelerated scrapping of old vintages and thus causes a diminished demand for labour (see among others Den Hartog (1984)). Hence, the increase in labour costs that exceeds the increase in labour productivity is responsible for a decreasing demand for labour. Empirical support for this conclusion is provided by the development of the share of labour income in total income. In the years $1972-1979$ real wage costs increased by $3.64 \%$, while labour productivity rose by $2.4 \%$ (averages). For the years $1980-1988$ the figures are $0.2 \%$ and $1.6 \%$ and in the period $1989-19950.2 \%$ and $1.7 \%$. The "mirror" image of these figures is that the share of labour income in total income has increased by 7 percentage-points during the period 1972-1979 and thereafter decreased by about 10 percentage-points, during the period $1980-1995 .{ }^{17}$

In the 1980 s the Dutch economy suffered from the effects of the second oil crisis in 1979. In order to prevent an increase in inflation, the government decided to stop the increase in its expenditures. Since there was a decrease in economic activity worldwide, economic growth was hampered and unemployment increased. After a while, the effects showed up in a slowing down of the wage increases.

If one takes also into account that the Dutch welfare state was developed mainly in the $1960 \mathrm{~s}$, one can imagine that when economic growth decreased in the 1970 s, a distribution problem occurred. Not only with respect to the distribution of total income between wages and profits but also concerning the division between the private and public sector. Moreover, these problems are related. Difficulties rose in financing an increasing public sector via higher taxes and premiums for social security. ${ }^{118}$ This led to a cry for a return to a coordinated wage policy instead of ad hoc policy measures or a continuous threat of them (see Van den Doel et al. (1976) and the comments by Pais (1976) and Fase (1980), ch. 9). However, in the post-1964 period, free negotiations remained the basis for wage determination.

17 Calculations are based on various volumes of the Centraal Economisch Plan issued by the Centraal Plan Bureau.

18 As in most European countries, during the postwar years and mainly in the 1960 s Dutch society became a welfare state. An extensive system of social security and a comprehensive amount of various governmental provisions was built up. In the sixties this was mainly financed from economic growth: in the seventies and eighties growth was insufficient thus creating the distribution problems mentioned. 


\subsection{Contract wages and wage drift}

\subsubsection{Wage drift}

In the foregoing sections wages that resulted from negotiations between organizations of employers and employees were discussed. These wages are regulated in a collective agreement, an explicit contract, and are therefore called contract wages. They differ from earned or effective wages. In the literature, the difference between the level of earned wages and the level of contract wages is often called earnings drift, while the difference between their development is called wage drift (Gerfin 1969). ${ }^{19}$ This section expands wage drift.

The sources for the existence of wage drift are manifold. First, note that the development of both contract wages and earned wages are calculated as average figures. One important assumption in calculating the average contract wage is that the composition and the structure of the labour force remains the same over the contract period. ${ }^{20}$ It follows that if the composition of the labour force changes, earned or effective wages differ from the calculated contract wage. Thus if, for example, the age distribution or male/female distribution changes from the assumed ones, wage drift is likely to occur. ${ }^{21}$

Second, in the Netherlands not all employees are covered by a collective agreement. As long as the non-contract wage increases differ from those resulting from the collective contracts, another source of wage drift is created.

Third, it is possible that wage increases exceed the agreements due to unforeseen circumstances for which no one can be blamed. Payment for overtime hours can serve as an example. In the collective agreement a tariff per overtime hour can be agreed, but the total costs of the agreement is unclear since the number of overtime hours is unknown.

Fourth, it is also possible that payments exceed the arranged contractual ones: there are excess payments. Note that, in contrast to the overtime payments, excess payments cannot be derived from the contract.

Finally it is possible that the calculated effects of agreed increases/decreases in wages differ from their proper effects because of miscalculations or lack of information.

19 A lot of authors mix earnings drift and wage drift: they call both the difference in levels and the difference in developments, wage drift (see e.g. Holden (1988); Moene (1988)).

20 The methodology of the calculations is explained in Centraal Bureau voor de Statistiek, Indexcijfers van Regelingslonen, methodebeschrijving en reeksen 1926-1974, Den Haag, Staatsuitgeverij, 1975.

21 This careful expression is used because changes can of course compensate each other. 
One may ask what the vital part of wage drift is. As has been observed, if wage drift is defined as the difference between the development in the earned/effective wage and that in the contract wage, it measures various things. Both structural developments, short term fluctuations and miscalculations as well as excess payments are incorporated. The difference between these is, however, that deviations due to structural developments, short term fluctuations and miscalculations can be "explained" by the contract, while the excess payments fall outside the agreement. This is the reason that not all of the difference between developments in the effective wages and the contract wages is called wage drift.

Gerfin (1969, p. 477) distinguishes between gross wage drift and net wage drift. Gross drift measures the total difference between the change in effective wages and contract wages, while net drift measures only the excess payments. In the Netherlands, the difference between the change in the effective wages and the contract wages is called "incidental" wage, while excess payments are called wage drift (which is thus a part of the incidental wage and equals net wage drift in terms of Gerfin). In the remaining part of this chapter I will use the Dutch terminology.

To summarize, the gap between the development of effective or earned wages and contract wages is called the incidental wage. Part of it is the wage drift which can be defined as that part of the change in wages that cannot be based on the collective contract which is valid for the industry/firm. From the definition it must be clear that the phenomenon of wage drift is only relevant at the level of the enterprise or the individual employee.

\subsubsection{Measurement and development of wage drift}

This section presents empirical evidence about wage drift during the postwar period and tentative explanations for the existence of wage drift.

The Dutch Central Bureau of Statistics publishes data on both contract wages and earned wages. Table 2.5 summarizes the measured wage drift during the period 19481993. The figures are averages over the period and measure the development for adult male industrial employees. The incidental is measured as the difference between the change in earned wages and contract wages. The wage drift is "net wage drift": that is the incidental wage minus the effect of a change in the structure of the labour force. ${ }^{22}$ Table 2.5 shows that during the years 1953/1963, the period of the bloom of the guided wage policy, gross wage drift was highest. Unfortunately, figures for net wage

22 According to the composition of the incidental wage as outlined in 2.4.1, it measures also the influence of wage increases of employees that are not subject to collective wage agreements and excess payments relating to overtime. For the wage developments of adult male industrial employees, however, these influences are negligible, see Centraal Bureau woor de Statistiek, 1975, p.7. 
drift are not available for this period and hence one cannot draw firm conclusions about the net wage drift. These figures correspond to the material presented in Gerfin. For the Netherlands he calculated during the period 1952-58 a rise in contract wages of $6.5 \%$, while gross wage drift amounted to $1.6 \%$. For the years 1958-65 the figures are $5.9 \%$ and $2.0 \%$ respectively.

Table 2.5 Contract wages (percentage changes) and wage drift in the Netherlands in the period 1948-1993

\begin{tabular}{|l|c|r|r|}
\hline Period & Contract Wages & Incidental & Wage drift \\
\hline $1948 / 1953$ & 4.3 & 1.6 & n.a \\
\hline $1954 / 1958$ & 7.0 & 1.6 & n.a \\
\hline $1959 / 1963$ & 5.7 & 2.5 & n.a \\
\hline $1964 / 1968$ & 9.8 & -0.2 & n.a \\
\hline $1969 / 1973$ & 11.1 & 1.4 & $0.2(72-73)$ \\
\hline $1974 / 1978$ & 7.6 & 1.0 & 0.5 \\
\hline $1979 / 1983$ & 2.4 & 0.8 & 0 \\
\hline $1984 / 1988$ & 2.3 & 2.1 & n.a \\
\hline $1989 / 1993$ & 3.5 & $0.4(89-91)$ & n.a \\
\hline
\end{tabular}

Sources: For the period 1948-1973: Centrall Bureau voor de Statistiek, 1975, p. 31. For the other years: Supplement to the social-economische mandstatistiek (CBS); For the years 1974-1978: H. van Reyin, Staat 1, weekly earnings. For the years 1979-1983: R.E.J. van der Werf, Staat 1 (weekly earnings). For the years 1984-1988: J. wan den Berg/J. Takkenberg, Staat 6 , weekly earnings (hence these are figures for 1985-1988). For the period 1989-1993: Ji. Hesemans.

n.a. means not available.

For the period after 1964 , wage drift is relatively moderate. The negative wage drift in the years immediately after 1964 is explained by the fact that in this period all kinds of so-called "black wages" were incorporated into the contract wages, giving a rise in the level of the contract wages. ${ }^{23}$

23 The term "black wages" is from Windmuller and De Galan (1977). This term denotes wages that were paid above the contract wage and were voluntary paid by employers. Sometimes these payments were illegall, but sometimes employers announced these payments. 
Finally, it is interesting to analyse the relation between a change in the contract wage and the wage drift. Scandinavian economists often claim that there is a positive relation between the development of the contract wage and wage drift (see e.g. Holden (1988)). They argue that wage drift results from rent sharing and when a higher contract wage decreases employment, the surplus is divided among fewer employees. In the Netherlands the view holds that wage drift corrects unfulfilled wage increases (Driehuis (1976), Lever (1993)). This implies that the relation between the development of contract wages and wage drift is negative. Figure 2.2 shows the percentage change in the contract wages and the incidental wage (percentage change in earned wages minus percentage change in contract wages) for the period 1948-1991. As I have discussed, the incidental wage is only an approximation of the "true" wage drift. The Dutch Bureau of Statistics has calculated net wage drift figures for the period 1973-1983. These are also incorporated in the figure, under the heading of wage drift.

Figure 2.2 The development of contract wages, incidental wages and wage drift in the Netherlands, 1948-1991

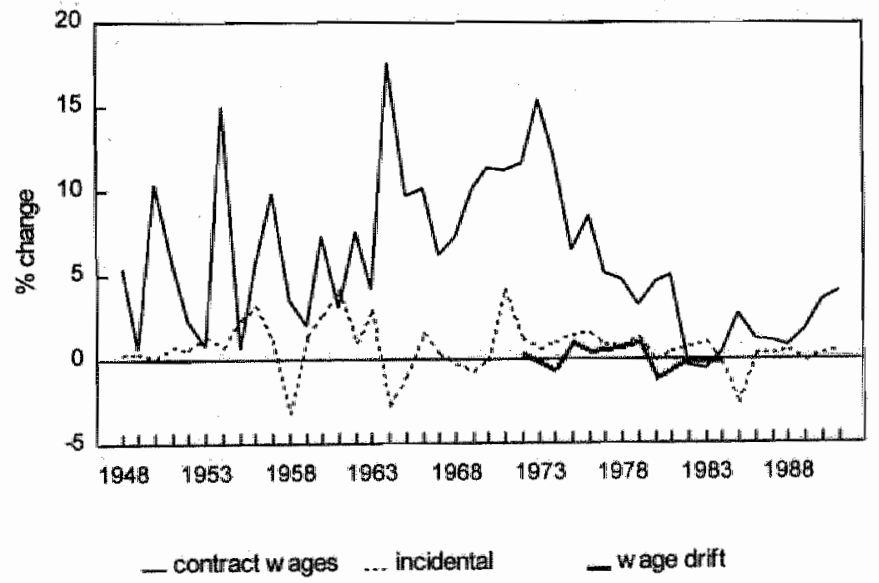

Figure 2.2 indicates that a positive relation between either gross or net wage drift and the development of contract wages does not hold for the Netherlands. In general, large changes in contract wages are accompanied by modest wage drift. This subject will be further discussed in chapter 4. 
Gerfin presents the results of a cross-country analysis. ${ }^{24}$ It is interesting to note that both countries with and without guided wage policies were investigated. From this research one can conclude that wage drift was highest in countries where governmental influence on wages was substantial.

\subsection{Conclusions}

This chapter discussed wage formation in the Netherlands in the period after 1945. The implementation and the abolition of the period of guided wage policy was described. This period was followed by years of relatively free bargaining. The position of the various parties was also clarified. What was striking was the shift of influence in the process of wage formation from the central organizations to the industry-level organizations. Thereafter I provided insight into the development of that part of the wages that is not agreed upon via a collective agreement.

One can summarize the foregoing part by noting that the famous Dutch central wage policy was rather successful in the 1950s. The large degree of postwar consensus about the necessity to rebuild the economy was an important success factor. However, when the economy recovered and industry developments became more heterogeneous, difficulties in continuing this policy increased. Further, Dutch labour relations have been characterized by a mixture of centralization and decentralization in wage negotiations during the post war period, despite the large extent of centralism. One can ask whether, from an economic point of view, the combination of centralization and decentralization is to be preferred over either centralization or decentralization of the wage negotiations. This topic has been in discussion during the recent years, and in chapter 5 I will elaborate this point further.

Guided wage policy did not survive in the Netherlands and notwithstanding the plea for a return to this policy in the mid-seventies, real discussion about such kind of policy has not taken place. The reason may lie in the expected ineffectiveness of the guided wage policy. Although the goals of guided wage policy can be multiple, I have focused on the development of wages. ${ }^{25}$ From Tables 2.1 and 2.5 I conclude that despite the prescriptions with regard to the wage developments, wage cost increases

24 To be more specific, Gerfin presents results for Sweden, Demmark, Norway, Finland, Austria, the Netherlands, Germany, United Kingdom, Switzerland, Italy, Ireland, Belgium and the United States. The analysis covers the years 1952-1965.

25

These goals can influence the (natural) rate of unemployment or expectations about inflation, to give a solution for the prisoner's dilemma or to cope with wage rigidity. However, each goal can only be reached if wage developments are moderate. 
continuously exceeded the wage norms. Part of these excesses are due to wage drift. From Table 2.5 it follows further that, on average, gross wage drift has diminished since the abolition of the period of guided wage policy. This conclusion about the ineffectiveness of the guided wage policy with regard to the control of the development of effective wages is reinforced by estimates of the wage equation for the Netherlands by Van Hulst (1984b). He concludes that no significant downward influence on wages can be found in periods of wage measures by the government (ch. 8$)^{26}$

In this chapter I did not deal with possible explanations for this ineffectiveness. As for the wage drift part, I refer to chapter 4 where wage drift is discussed. Further, I refer to Table 2.2 of this chapter, where a summary of some important economic indicators, sketching the economic environment of the period of guided wage policy, is presented. I conclude that the developments of these indicators were unfavourable for the continuation of the guided wage policy. Demand for labour exceeded the supply of labour and, although wages are not the result of demand and supply in as simple a way as is sketched in neo-classical theory, I hold the view that a price policy that neglects market forces cannot survive in the long run. Guided wage policy eliminates the process of pricing, but not the development of the underlying economic forces that determine the scarcity of a good.

Another problem with respect to guided wage policy concerns the relations between the goals and the instruments. As Tinbergen has shown us, if $x$ goals have to be reached, $x$ instruments have to be used. Thus if the aim of guided wage policy was not only moderation of wage developments but also price and employment policy, more instruments had to be used. For example, apart from wage guidelines, employment guidelines can be introduced.

Finally, in Dutch wage setting two elements continuously show up: first, wage bargaining and second, the centralization-decentralization debate. I will elaborate on these characteristics in chapters 3 and 5 . The next chapter first analyses modern approaches to wage bargaining and in chapter 5 the merits and demerits of centralization and decentralization are discussed.

26 The research of Van Hulst covers Dutch policy. However, the same results have been achieved for the United States and the United Kingdom, see Van Hulst (1984b), Ch. 6/7. 
APPENDIX 2 List of the used abbreviations

In this chapter, especially in section 2.3.2 T have used a number of abbreviations. This appendix writes the full names.

\begin{tabular}{|c|c|c|}
\hline 10 & & \\
\hline NV & & tional Union (Federation) (Christelijk Natio \\
\hline & & Unions \\
\hline & & $\begin{array}{l}\text { in Union of Farmers and Market-gardeners (Katholieke Neder- } \\
\text { - en Tuindersbond) }\end{array}$ \\
\hline$\pi$ & & $\begin{array}{l}\text { Royal Dutch Agriculture Comittee (Koninklijk Nederlands Landbouw } \\
\text { Comité) }\end{array}$ \\
\hline NOV & & $\begin{array}{l}\text { Royal Dutch Entrepreneurs Union (Federation) (Koninklijke } \mathrm{Ne} \\
\text { Ondernemers Verbond) }\end{array}$ \\
\hline $\mathrm{HP}$ & & $\begin{array}{l}\text { or highly skilled employees ( } \mathrm{V} \\
\text { eeel) }\end{array}$ \\
\hline $\mathrm{EBT}$ & & $\begin{array}{l}\text { Dutch Christian Union of Farmers and Market-gardeners. (Nederlandse } \\
\text { Christelijke Boeren- en Tuindersbond) }\end{array}$ \\
\hline $\mathrm{CW}$ & & $\begin{array}{l}\text { Dutch Christian Employers Federation (Nederlands Christelijk } \\
\text { Werkgeversverbond) }\end{array}$ \\
\hline 0 & & $\begin{array}{l}\text { Dutch Christian Entrepreneurs Union (Nederlands Christelijk Ondernem } \\
\text { Verbond) }\end{array}$ \\
\hline & & es (Verbond van Nederlandse Ondernemin \\
\hline
\end{tabular}




\section{UNION BEHAVIOUR AND WAGE BARGAINING*}

From the previous chapter I conclude that both wage bargaining and some sort of centralization are relevant in the Duteh labour relations. Apart from these issues, there is wage drif. In the coming three chapters, these issues are elaborated. This chapter expands on wage bargaining and discusses so-called axiomatic bargaining models: given a number of assumptions, one can determine and amalyse the solution of the bargaining process. I do not discuss the steps that are taken during the negotiations.

With the contribution of MeDonald and Solow (1981), based on some idens already published by Leontief (1946) and to some extent also by Hall and Lilien (1979), new insights into the theory of trade unions and wage bargaining have been developed. A part from the well-known monopoly model of Dunlop (1944), they stress the possibility of efficient bargaining. It turns out that a Pareto efficient bargaining solution can be reached when unions and firms bargain about wages and employment.

This chapter gives a short survey of these moderm developinents. Besides theoretical developments I will pay attention to empinical research in this area.

\subsection{Introduction}

Since wage formation on the labour market in most countries has been characterized by wage bargaining (for the situation in the Netherlands I refer to chapter 2), union behaviour and bargaining theory have attracted much attention.

Many papers have been dedicated to union behaviour and wage bargaining. I will introduce the topic of this chapter by singling out six contributions. In his seminal work about wages and the workings of the labour market, Hicks (1932) already discussed the difference between a competitive labour market and a labour market where unions and employers bargain about the wages. Whereas Hicks started a branch of research in which the bargaining process is the focus, Dunlop (1944) opened a discussion about the utility function of unions and the wage/employment solution in the case where wages are determined solely by the unions and employment by employers.

Parts of this chapter have been published before, see Van Veen (1989), Albeda and Van Veen (1990) and Lever and Van Veen (1991). 
McDonald and Solow (1981) extended Dunlop's analysis by analysing a contract where employers and employees bargain about wages and employment simultaneously. Finally, Manning (1987) can be given credit for his attempt to develop an encompassing view on models of wage bargaining. Note that in these latter types of models the bargaining process as such is not discussed, but the solution that will be reached in yarious bargaining settings.

Two contributions are also worthy of mention. First, the development of wage bargaining theory could be summarized by noting that "it is all in Leontief", because Leontief (1946) discusses both the Dunlop and the McDonald/Solow approach using an Edgeworth box diagram. Second, during the development of wage bargaining theory, the results of game theory, especially concerning bargaining solutions, gained importance. In this respect, the Nash solution, based on Nash (1950) has proved to be a dominant solution concept among labour economists.

In this chapter I will discuss the postwar developments in the theory of union behaviour and wage bargaining starting with the analysis of Leontief and summarize the main ideas using the approach of Manning (3.3). After discussing the models, I take a closer look at some specific elements of modern wage bargaining theory, in particular union utility functions and bargaining solutions (3.4). Thereafter attention is paid to empirical research concerning the models that I have discussed (3.5). Comments on the applicability of the models are given in 3.6 and section 3.7 is a conclusion. Related surveys of (axiomatic) wage bargaining models can be found among others in Pencavel $(1985 ; 1991)$, Oswald (1985), Lever and Van Veen (1991) and Booth (1995). This chapter differs from these surveys on two points. First, in most surveys only the labour demand equilibrium model/right-to-manage model and the contract curve equilibrium model are discussed, while I explicitly start from the basic model that was provided by Leontief and use Manning's approach for a summary of the models. Both Leontief and Manning contain a wider range of models. Second, I explicitly pay attention to game-theoretic aspects that are often implicitly incorporated in these models. I will start, however, in the next section with some preliminary remarks to introduce wage bargaining.

\subsection{Preliminary remarks}

According to neo-classical theory, in equilibrium nominal wages are equal to the narginal revenue product of labour. This follows from profit maximizing behaviour of the firms. Various regimes can exist under which this equality is reached, for example, in perfectly competitive markets but also when monopolistic elements are present (Hicks, 1932). Only in a situation of bilateral monopoly are the price and quantity in 
the market indeterminate (Koutsoyiannis (1979), Mamuth (1992)). Table 3.1 sketches the various possibilities.

If perfect competition prevails on both sides of the market, wages are "given" to the parties and equal the marginal revenue product of labour (mrpl). If labour supply is embodied in one union, while on the demand side no organization is present, union goals determine the wages.

Table 3.1 Types of competition on the labour market and the determination of wages $^{1}$

\begin{tabular}{||l|l|l|}
\hline $\begin{array}{l}\text { labour demand } \\
\downarrow\end{array}$ & \multicolumn{1}{|c|}{$\downarrow$} & labour supply \\
\cline { 2 - 3 } & perfect competition & monopolist \\
\hline perfect competition & $\mathrm{W}=\mathrm{mrpl}$ & $\begin{array}{l}\mathrm{W}=\mathrm{f}(\text { union goals) } \\
\text { s.t. W }=\text { mrpl }\end{array}$ \\
\hline monopsonist & mel = mrpl & wages are indeterminate \\
\hline
\end{tabular}

W $=$ nominal wages;

$\mathrm{mrpl}=$ marginal revenue product of labour;

mel = marginal expenditure on labour.

Maximization of the wage bill or employment may be such goals. In this case, however, unions are constrained by the demand for labour. If unorganized labour supply is confronted with one party representing demand, the monopsonist will set the wages such that marginal expenditure on labour (mel) equals the mrpl. In a situation of bilateral monopoly, wages are indeterminate. The reason is that the wage rate that maximizes the parties' positions is not the same for the participants. This means that this model gives only upper and lower limits within which the wage rate will be determined by bargaining.

In order to elaborate on this indeterminateness, various types of models have been developed which characterize solutions under these regimes. According to these models wages are the result of a bargaining process between employers and employees. In this chapter I survey various types of bargaining models and analyse the position of both sides on the market in this process. I basically discuss monopolyperfect competition models and bilateral monopoly models.

1 In this table I assume perfect competition on the goods market. 


\subsection{Wages, employment and contracts}

\subsubsection{Leontiefs analysis}

As $I$ announced in the introduction, I start the discussion with Leontief's analysis (1946). This enables to highlight a few concepts that will be important in the remaining part of this chapter. The analysis is based on a graphical presentation of an exchange situation, using the Edgeworth box.

Leontief analyses a situation where two parties must exchange two goods. Assuming that each party consists of identical individuals, the analysis is reduced to an exchange of two goods ( $\mathrm{A}$ and $\mathrm{B}$ ) between two individuals. Leontief implicitly assumes that parties aim at maximizing their utility. The Edgeworth box can be helpful in elaborating this problem and this is exactly the way Leontief approaches this problem. His analysis is discussed with the help of Figure 3.1.

Figure 3.1 Edgeworth box with regard to the exchange of two goods between two individuals

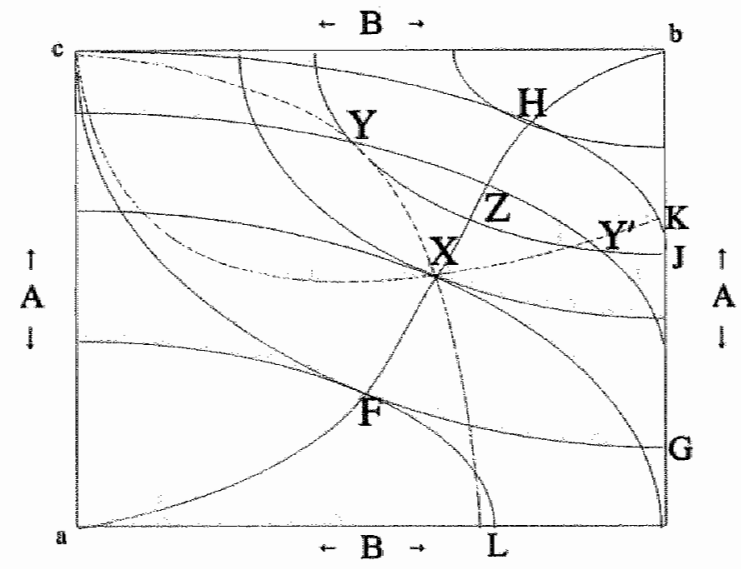

Point $a$ is the origin for the sellers of good A, point $b$ for the sellers of good B. Let us call individual 1 the seller of good A and individual 2 the seller of good B. cFG and $\mathrm{cHJ}$ are indifference curves for individual 1 and 2 respectively. Factor endowments are measured from point $\mathrm{c}$, the starting point of the analysis. This means that ac equals the 
endowments of individual 1 and $b c$ is the endowments of individual 2. What are these endowments? In this model individual 1 exchanges good A for good B, that is owned by individual 2 . Hence, individual 1 "ownes" good $A$, whereas individual 2 "ownes" good $B .^{2}$ Note that along an indifference curve for individuall 1 a movement from $\mathrm{c}$ to $a$ along with a movement from $c$ to $b$ implies that an amount of good $A$ is exchanged for an amount of good B.

In addition to the indifference curves, offer curves are drawn. An offer curve is a set of optimal (bargaining) points for a party given the terms of trade. The terms of trade can be derived by taking the slope of any straight line from the origin. ${ }^{3}$ This means that the offer curve of individual 1 denotes the amount of good $\mathrm{A}$ that he is prepared to exchange with the counterparty at a given price. The offer curve is consequently the locus of points combining the highest possible indifference curves at the various terms of trade. In the same way, the offer curve for individual 2 has to be interpreted. In Figure $3.1 \mathrm{cK}$ denotes the offer curve for individual 1 and $\mathrm{cL}$ for individual 2. Finally the curve $a b$ is drawn. This curve connects points of tangency between indifference curves of the parties and is called the contract curve. Note that an important characteristic of the contract curve is the Pareto-optimality of the solutions that lie on this curve. ${ }^{4}$

Within this general framework of exchange, Leontief argues, several equilibrium situations are possible and he discusses 3 solutions in particular. First, if perfect competition prevails on both sides of the market, the exchange process will lead to an equilibrium where both parties find their optimal bargaining units on their offer curves. Then it is clear that only at the point of intersection of two offer curves equilibrium occurs and the solution is Pareto-optimal (cf. point X).

Second, if monopolistic combinations prevail, one must distinguish between two kinds of contracts according to Leontief. First, there is the "standard" type of monopoly situation where one party sets the price while the other party is able to determine freely the amount of his purchase. In this case, the solution lies on an offer curve but not necessarily at the intersection point $X$. For example, suppose that individual 1 sets the terms of trade, while individual 2 adjusts the amount that will be purchased. Then individual $\mathbb{1}$ will choose that point on individual 2's offer curve that

2. Leontief discusses an exchange between two groups. Each group consists of identical individuals: that is identical with respect to preferences, but also to endowments (Leontief, p. 76).

3 Note that when such a straight line from point c turns to the right (viewed from point c) the price of good $B$ rises and the other way around.

4 In wage bargaining theory, Pareto-optimality is also called "efficiency". 
would place individual 1 on his highest possible indifference curve. This solution is denoted as $\mathrm{Y}$ in figure 3.1. Second, however, if the monopolist succeeds in selling a contract that guarantees him a certain revenue, another solution is possible. In this case, the monopolist creates a take-it-or-leave-it position and now the buyers face a choice between either engage into the guaranteed revenue contract or no exchange at all. In this case, the seller will choose a point that maximizes his utility given the utility scheme of the buyers. It will be clear that in this case the utility of the buyers will be minimized. The buyyer's minimum utility is determined by abstaining from trade and is thus represented by the indifference curve through point $\mathrm{c}$. Consequently, point $H$ will be the solution in case individual 1 has full power over all the bargaining items. Note that this solution lies on the contract curve and is therefore Pareto-optimal. Further it is stressed that this solution can only be reached if the monopolist can determine both the price and the quantity. Finally it is clear that this solution is more profitable for the seller and less profitable for the buyer (as opposed to the first monopoly case).

From the approach of Leontief, three conclusions can be drawn.

1. If perfect competition prevails on both sides of the market, the exchange process leads to a solution that lies on the offer curve for both parties as well as on the contract curve.

2. If the monopolist unilaterally establishes the price, the solution lies on the offer curve for the buyers, but not on the contract-curve. This means that the solution is not Pareto-optimal.

3. If both the level of wages and the amount of employment are determined by the monopolist, the bargaining solution lies on the contract curve. This solution is Pareto-optimal.

As an example of a monopolist that determines both price and quantity, Leontief mentions a union that bargains about a guaranteed annual wage contract. In such contracts not only the wages are fixed, but also the minimum wage bill that has to be paid by the employers. The nice point of Leontief's analysis is that he clearly shows the difference between a standard monopoly model and a model where the monopolist sets both the prices and the quantities. ${ }^{5}$ It is therefore not surprising that the wage bargaining literature after Leontief has especially focussed on conclusion 2 and

5 Note that in the annual guaranteed wage contract as defined by Leontief, the quantities are not explicitly determined. If at the wage that is set, profit-maximizing employment is such that the wage bill exceeds the guaranteed wage bill, employers can freely choose the level of employment. Only if the profit maximizing level of employment is too low, employers are forced to increase the level of employment. 
conclusion 3. I will next discuss a standard monopoly wage bargaining model and a model that results in an efficient solution.

\subsubsection{The labour demand equilibrium model}

It is assumed that two parties, unions and firms, are involved in the wage setting/wage bargaining process and that utility functions for both parties exist. These utility functions both incorporate wages (W) and employment (L) as arguments. Assume that the utility function of the union is equal to $U=U(W, L)$ (with $U_{W}, U_{L}>0$ and $U_{W W}$ and $U_{L L}<0$ ) and that there exist iso-utility sets for unions whereby a certain level of utility can be reached with different combinations of wages and employment. Next, it is assumed that there exists a revenue function, $R=R(L ; K$, with $L=$ employment and $\mathbb{K}=$ Capital) for which the Inada conditions holds. ${ }^{6}$ The utility of the employers is measured by their profits $\pi(W, L)=R(L)$ - WL. Employers can reach a certain level of profit with different combinations of wages and employment; for this party iso-profit curves can be constructed, as will be seen. This starting point resembles Hall and Lilien (1979), McDonald and Solow (1981), Oswald (1984, 1985) and Pencavel (1985).

I start with the analysis of the standard monopoly model, where wages are unilaterally set by the unions. Employers determine unilaterally the level of employment by equating marginal costs and marginal returns along the labour demand curve. Hence, analytically the following problem must be solved:

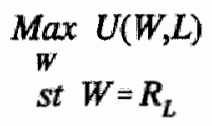

where $U=$ union utility, $W$ is the wage rate and $L$ is employment. Since employers determine employment along the labour demand curve, the wage rate must lie on the labour demand curve, i.e. the wage rate must equal the marginal revenue product of labour $\left(R_{L}\right)$.

The first-order condition for the solution of this problem is

6 Revenue is by definition the nominal value of the production. Hence $R=p \cdot Q(L ; K)$. If one assumes that prices are constant, the Inada conditions apply to the production function. Note that in the analysis the amount of capital is fixed. I assume $Q(L ; K)$ to be strictly concave and the Inada conditions are defined as: $Q(0)=0 ; Q_{(0)}=\infty ; Q_{(\infty \infty)}=0$ (Blanchard and Fischer (1989)). 


$$
U_{u} d W+U_{L} \frac{d L}{d W} d W=0
$$

where $\mathrm{W}=\mathrm{R}_{\mathrm{L}}$

and it follows that the solution is found by

$$
\frac{U_{L}}{U_{W}}=-\frac{d W}{d L}=-\frac{d\left(R_{L}\right)}{d L}
$$

The left hand side of equation (3.3) is the marginal rate of substitution between wages and employment of the union and the right hand side is the slope of the labour demand curve. The right hand side thus is the rate at which employers wants to substitute wages and employment if they strive after maximization of profits.

Figure 3.2 presents a graphical analysis of this model. A labour demand curve (DD') has been drawn (assuming profit maximizing behaviour this curve is derived from a production function and along this curve the wage rate equals the marginal revenue product of labour) and an union indifference curve $\left(\mathrm{CC}^{\prime}\right)$.

Figure 3.2 The labour demand equilibrium model

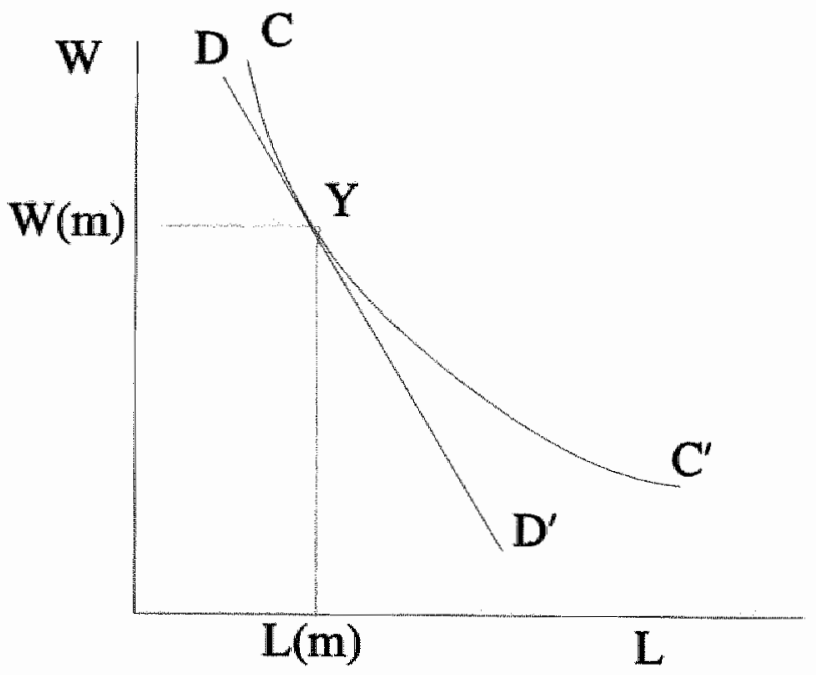


In this model unions, knowing the labour demand curve, decide from their preference function which wage claim they will put to the employers. Employers simply adjust employment according to this claim while the wage claim is honoured. The solution is denoted by point $Y$. This result is characterized by an employment level $(L(m))$ that maximizes profit for the employer given the wage rate and maximum utility (that means the highest indifference curve that can be reached) for the union given the demand for labour (reached when the wage rate equals $W(m)$ ), which act as a constraint in this model. Following MaCurdy and Pencavel (1986) I will call this model the labour demand equilibrium model (LDEM). Note that it is assumed that unions strive after maximizing utility and employers maximize profits.

The model that is discussed in this section can be seen as the labour market equivalent of the "conventional" monopolistic model as was sketched by Leontief. Although Leontief distinguishes another type of monopoly contract, some authors stressed that this conventional monopoly model might not occur very frequent, since wages are mostly bargained instead of unilaterally set. In the model that is discussed in the next section this bargaining is introduced.

\subsubsection{Right-to-manage}

Nickell and Andrews (1983) develop a generalization of the labour demand equilibrium model. They state that although firms retain "the right to manage" the employment in the LDEM given the nominal wage, it is important to note that the union and the employers bargain about the wages (see also Layard and Nickell (1987)). This model, where unions and employers bargain about the wages, while employers set unilaterally the wage rate is called the right-to-manage model (RTM). Nickell and Andrews give no explicit arguments for their bargaining idea, stating: "Here we suppose that although unions are aware of the demand curve, they and the employers actually bargain about the wage" (p. 184). Hence the described unilateral monopoly of the union concerning the wages is an extreme case; the case in which employers have no bargaining power in the wage bargain.

Although the amendment on the labour demand equilibrium model seems at first sight marginal, a major difference is that since bargaining prevails, a bargaining solution has to be determined. In labour economics, the Nash bargaining solution has become the main solution concept and I follow this practice. This Nash solution can be found by maximizing the product of the utility functions of the bargaining parties. By giving the utility functions a weight, $\mathrm{c}$ and $(1-\mathrm{c})$, denoting bargaining power, I admit both symmetric and asymmetric Nash solutions. This is called the generalized Nash 
bargaining solution. Note that $\mathrm{c}$ is assumed to lie between 0 (no bargaining power) and 1 (full bargaining power). ${ }^{7}$ In section 3.4.2 1 elaborate on this solution concept.

Recall that, in determining wages and employment, first the wage is bargained upon and second, employment is set by employers. It will be clear that employment is set on the labour demand curve. Using the Nash bargaining solution, a right-to-manage model solves

$$
\begin{gathered}
\underset{W}{\operatorname{Max}} N=\left\{U(W, L)^{c} \cdot(R(L)-W L)^{1-c}\right\} \\
\text { st } W=R_{L}
\end{gathered}
$$

where $\mathrm{N}$ is the Nash maximand, i.e. the product of the utility functions of the bargaining parties and $\mathrm{c}$ is the bargaining power of the unions. It can easily be derived that the generall solution reads ${ }^{8}$

$$
c \frac{d U / d W}{U}=-(1-c) \frac{d \pi / d W}{\pi}
$$

and elaboration of equation (3.5) using the unspecified functions from the Nash maximand results in the well-known first order condition for the wages (Ulph and Ulph (1990), Booth (1995))

$$
c \cdot \frac{U_{W} W}{U(W, L)}=c \cdot \frac{L \cdot U_{L} \cdot \epsilon^{W}}{U(W, L)}+(1-c) \frac{W \cdot L}{R(L)-W \cdot L}
$$

where $\varepsilon^{W}$ is the wage elasticity of labour demand ( $\left.-(d L / d W) . W / L\right)$. Basically this equation says that in equilibrium, the percentage increase in union utility following a wage increase is equal to the loss in the utility of the employer, see equation 3.5. Note that the gains and losses are premultiplied by the bargaining power. However, an increase in wages has both a positive and a negative effect on union utility. The negative effect stems from the decrease in employment that follows a wage increase. Hence, in equilibrium the utility gain for the union equals the percentage decrease in the union's utility because of the loss of employment plus the loss in the utility of the

7 To be more precise: if $\mathrm{c}$ is the weight attached to the union's utility function, then $\mathrm{c}$ is the bargaining power of the unions. Because $0 \leq c \leq 1$ it follows that $(1-c)$ is the bargaining power of the other party, the employers.

8 Note that $\mathrm{dU} / \mathrm{dw}$ (the total derivative) differs from $\mathrm{U}_{\mathrm{w}}$ (the partial derivative, i.e. keeping employment fixed). 
employer, see equation (3.6). It follows further that the wage rate is related to the ratio of the bargaining power of the parties. From (3.5) it follows that as c increases, $(d U / d W) / U(W, L)$ decreases and hence the wage rate increases. This is in accordance with my expectations, because an increase in c simply is an increase in the bargaining power of the employees.

Finally, the results of the LDEM can derived from the first order condition of the RTM. Rewrite equation (3.3) and find

$$
\epsilon^{W}=\frac{W U_{W}}{L U_{L}}
$$

and it can easily be checked that this expression also results from equation (3.6) when $c=1$.

Figure 3.3 The right-to-manage model

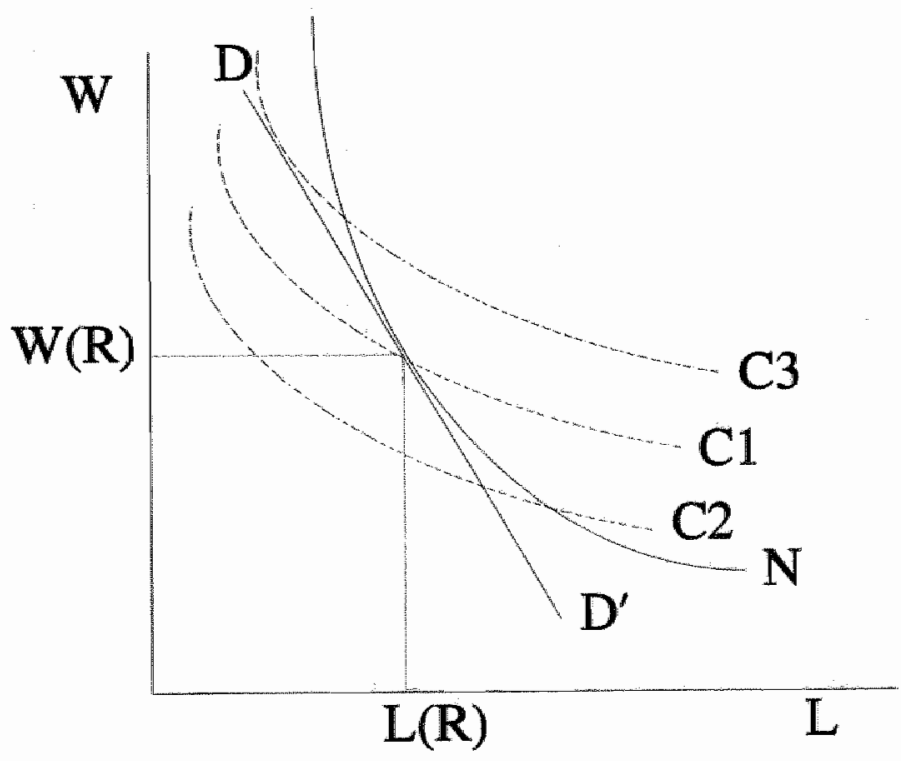

The graph of this model differs from the LDEM. In the RTM case, the solution is a point of tangency between the Nash curve and the labour demand curve. The Nash curve is derived from the first order condition of the maximization problem (cf. equation 3.5 or 3.6) and shows combinations of wages and employment that fulfils this first order condition for the Nash bargaining solution. In Figure 3.3 the Nash curve is 
denoted by $\mathrm{N}, \mathrm{C} 1, \mathrm{C} 2$ and $\mathrm{C} 3$ are union's indifference curves and DD'is the labour demand curve.

It is obvious that because unions are no longer able to choose the highest possible indifference curve (C3), the equilibrium (W(R), L(R)) is characterized by intersection between an indifference curve and the labour demand curve. This implies that the equality of the marginal rate of substitution from the utility function to the trade-off between wages and employment according to the labour demand curve is broken. Now there is equality between the trade-off and the "feasible" marginal rate of substitution. In appendix 3 the labour demand model and the right-to-manage model are compared in more detail.

Finally let us rewrite the first order condition (in particular equation 3.5 ) into a "neat" expression for the wage rate to find

$$
W=\frac{R(L)}{L}-\frac{(1-c)}{c} \frac{U(W, L)}{d U / d W}
$$

This expression makes clear that the wages are at maximum equal to the average product of labour (if $\mathrm{c}=1$ ).

\subsubsection{The contract curve equilibrium model}

Leontief has pointed out that in case the monopolist sets the price and the quantity and makes a take-it-or-leave-it proposition, a point on the contract curve can be reached. But in this case one party, the buyer, gets worse off while the seller gains. It is, however, not difficult to notice that from the conventional monopoly solution a Pareto improvement (i.e. an improvement that benefits at least one party without harming another party) is possible. In Figure 3.1: any point that lies in the lens between $Y$ and $Y^{\prime \prime}$ is a Pareto improvement, if one starts in $Y$. Note that such points will not be reached when the price is set by the monopolist. Neither will these points be reached when the monopolist sets the price and the quantity. To reach these Pareto improvements, parties need to bargain about wages and employment. This idea is elaborated in the contract curve equilibrium model, which has been brought under attention by McDonald and Solow (1981). I will discus this model in this section.

In the previous models employment was set on the labour demand curve. I start by showing that the solutions in the labour demand equilibrium model and in the rightto-manage model are not Pareto efficient and need a few steps to elaborate on this point. I start with a graphical presentation and thereafter the solution is calculated. 
First, iso-profit curves in the wage-employment space can be derived. Along an iso-profit line, $\mathrm{d} \pi(\mathrm{W}, \mathrm{L})=0 \mathrm{so}^{9}$

$$
\frac{d W}{d L}=\frac{R_{L}-W}{L}
$$

gives the slope of an iso-profit line. Note that the slope is not constant at changing employment levels. The sign of the slope depends on the sign of $R_{L}-W$. If $R_{L}>W$, the slope is positive; if $R_{L}<W$, the slope is negative and if $R_{L}=W$, the slope $=0$. Further, recall that along the demand for labour curve wages equal the marginal revenue product of labour, i.e. $R_{\mathrm{L}}=\mathrm{W}$. Consequently the labour demand curve intersects with the top of the isoprofit curves. In Figure 3.4, some iso-profit curves are shown (P1..P4). If these isoprofit lines are compared, one can establish that from P1 till P4 profits rise because for any level of employment, wages along P4 are less than along P1 to P3. Next the iso-profit curves are incorporated in Figure 3.2, this results in Figure 3.4, a figure like Figure 3.2 and with DD" being the labour demand curve and $C$ the indifference curve of the union.

As in the Leontief analysis (and already extensively discussed by Edgeworth), Pareto-improving bargaining possibilities exist until the solution fulfils the condition that the indifference curves are tangential. In the situation as depicted in Figure 3.4, bargaining can lead to an increase in utility for the unions if employers are prepared to offer more employment in case of a decrease in wage claims than the increase they offer according to the labour demand curve. Employers will, given that they aim at maximizing their profits, only enter in such bargain when their profits rise. Now a bargain is possible in which both employers and trade unions can gain: these bargains are called Pareto-optimal or efficient bargains.

For the analysis, Figure 3.5 is used, with $\mathrm{Pa}, \mathrm{Pb}$ as iso-profit lines, $\mathrm{C} 1$ and $\mathrm{C} 2$ are indifference curves and $\mathrm{DD}^{\prime}$ is the demand for labour. Let us assume that the starting point is at $\mathrm{A}$. This means that unions have set the level of wages at $\mathrm{W}^{\prime \prime}$ and employers use L' labour as input for their production. Remember, $A$ is the optimal solution for both parties if unions set unilaterally the wages and employers set employment. If one next assumes that both employment and wages are the bargaining items, point $\mathrm{B}$ or point $\mathrm{C}$ can be reached. Both points are Pareto-improvements with respect to point $\mathrm{A}$.

9 See page 45 for the definition of profits. 
Figure 3.4 The relation between iso-profit curves, iso-utility curves and the demand for labour

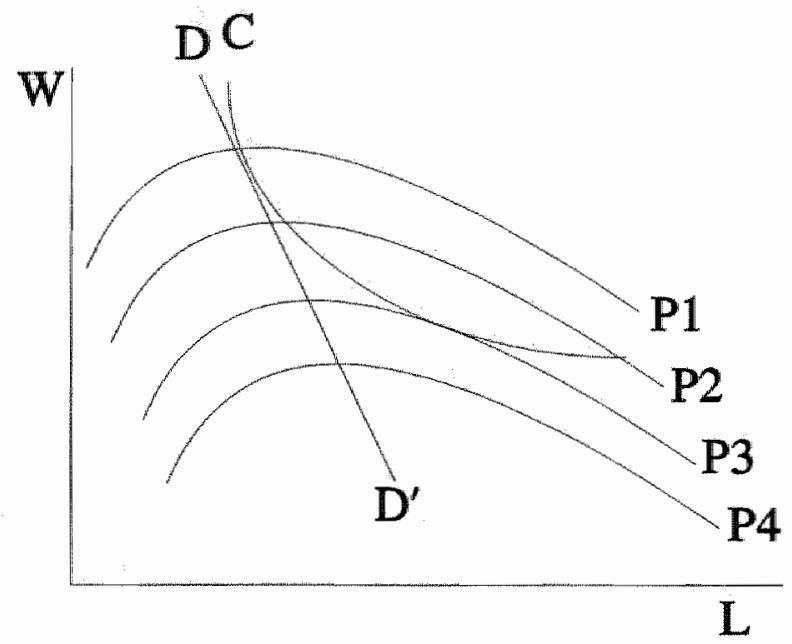

Figure 3.5 Efficient bargains

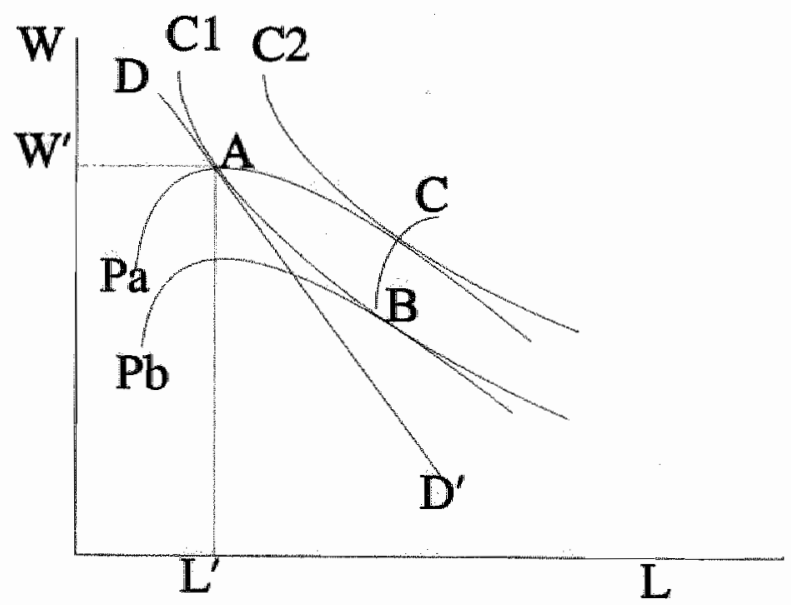


Starting at point $A$, unions may offer a decrease of wages in exchange for employment. According to the labour demand curve, this is always possible but, and this is the essence of this type of model, the employment compensation offered by the firms must exceed the compensation offered according to the labour demand curve in order to have a profitable bargain for the unions (point C). For the firms this means that they have to hire more employment than if they should otherwise do. This implies that unions must have influence over the employment decision. In the same way point $B$ is a more profitable bargain than point $A$ for the employers.

Obviously, points $\mathrm{B}$ and $\mathrm{C}$ are not the only points at which profitable bargains can be reached. In fact, there is a set of optimal points which have in common that the slope of the indifference curve equals the slope of the isoprofit curve. The set of these points is called Pareto-efficient bargaining points and they can be denoted as:

$$
(W, L) \mid-\frac{U_{L}}{U_{W}}=\frac{R_{L}-W}{L}
$$

Note that a contract curve is defined as the locus of the Pareto efficient bargaining points. Reorganizing equation (3.10) then gives the following expression for the wage rate along the contract curve

$$
W=R_{L}+L \frac{U_{L}}{U_{W}}
$$

It follows that unless $U_{L}=0$ (for example in case unions do not care about employment), the contract curve is characterized by the fact that the wage rate exceeds the marginal revenue product of labour. Or, the wage/employment combination is off the labour demand curve. ${ }^{10}$

Again following MaCurdy and Pencavel (1986), I call this model the contract curve equilibrium model (CEM). The conclusion so far is that Pareto-efficient or Pareto-optimal bargains can be reached at the contractcurve. The question next rises, at which point on the contractcurve the parties will reach a bargain. To solve this problem, one needs a bargaining solution concept.

10 Although I hawe drawn a positively sloped contract curve, this curve can be negatively sloped or vertical as well. Or, the slope is not unconditional positive. The sign of the slope depends on the specification of the utility function, see also section 3.4 .2 . 
As I have stated in the discussion of the right-to-manage model, the Nash bargaining solution is widely used in labour economics (Nash (1950), McDonald and Solow (1981), Svejnar (1986) while Johansen (1979) and Pencavel (1991) give a short survey of various solution concepts). This solution concept can also be used in the CEM model. Note, however, that in the CEM model, wages and employment are bargained upon. If one uses the Nash bargaining solution, this can be modelled as

$$
\max _{W, L} N=U(W, L)^{c} V(W, L)^{(1-c)}
$$

with $\mathrm{N}$ is, as before, the Nash maximand and $\mathrm{V}(\mathrm{W}, \mathrm{L})$ denotes the utility of the employers. ${ }^{11}$ The result for the wage rate reads ${ }^{12}$

$$
W=\frac{R(L)}{L}-\frac{1-c}{c} \frac{U(W, L)}{U_{W}}
$$

Although this expression for the wage rate may not seem to be clear immediately, it is not difficult to interpret this result. When employees have all bargaining power, $\mathrm{c}=1$ and the wage rate is equal to the average product of labour. On the contrary, when employers have all power, the wage rate equals the marginal product of labour. Note that this does not follow from (3.13) but from (3.12) with $\mathrm{c}=0$. Consequently, for $0<\mathrm{c}<1$ the wage rate is between the average product and the marginal product. This is quite intuitive, because in this model basically the rent is shared between the bargaining parties. The rent is the difference between the average product of labour and the marginal product of labour, while the share that each party receives of this rent depends on the distribution of the bargaining power.

\subsubsection{A summary: the (encompassing) analysis of Manning's sequential bargaining model}

In the previous sections I gave a rather detailed analysis of the effects of union behaviour on wages and employment as it has been developed in the literature in the eighties. Notwithstanding the details, I could only give a broad survey. Differentiations

11 Throughout this study $V(W, L)=\pi(W, L)=R(L)-W L$.

12. The solution is calculated from the contract curve and the first order condition of the Nash maximand towards employment, see Appendix 3A. 
of this broad picture can be found, amongst others, in Hall and Lilien (1979), McDonald and Solow (1981), Black and Bulkley (1984), Pencavel (1984, 1991), Oswald (1985) and Booth (1995). This section summarizes the main characteristics of the previous models using the framework that has been developed by Manning (1987). This framework is both simple and ingenious: he uses the idea that basically it is possible to bargain only about wages or about wages and employment. If the bargain is about wages, a wage maximand must be solved and the same is true for employment. The important point that Manning makes is, however, that the bargaining power of the parties need not be the same in a wage or an employment bargain as is assumed by McDonald and Solow. Hence, Manning develops a framework where the bargain is split up between wage bargaining and employment bargaining. Now Manning distinguishes between a model where there is first bargaining over the wages and thereafter bargaining over employment and a model where the sequence of the bargaining is just the other way around: first employment, second wages. He calls his approach a sequential bargaining model and argues that the models that have been discussed before (LDEM, RTM and CEM) are incorporated in his sequential bargaining approach, in particular in the wage-employment type of bargaining. Moreover, there is another class of models incorporated in his approach, that is not discussed as will be seen. So, in contrast to the authors that I have mentioned before, Manning explicitly pays attention to the organization of the bargaining process. I will follow his analysis and note that the assumptions that were made in the beginning of section 3.3.2 concerning the utility function, the revenue function and the profit function are still used.

In Table 3.2 I show the functions that must be maximized under various regimes and using the Nash bargaining solution concept.

Model 1 is the Manning model: bargaining is about both wages and employment. Since I start with the wage bargain, this is a wage-employment bargain. If $\mathrm{W}$ and $\mathrm{L}$ are changed, an employment-wage bargain follows. Note that in the set-up of the first row of Table 3.2, the bargaining power in the wage bargain ( $p$ and (1-p)) differs from the bargaining power in the employment bargain ( $q$ and $(1-q)$ ). Now Manning argues that $p=q$ is a sufficient condition for efficiency whatever the sequence of bargaining is. ${ }^{13}$

13 Manning argues that if $p=q_{i}$ the objective function in the wage bargain is the same as the abjective function in the employment bargain and then efficiency follows sitraightforwardly from the envelope theorem (Manning, p. 126). Note further that one of the implications of this proposition is that the inequality of $p$ and $q$ causes inefficiencies. This point is also stressed by Manning. One may further wonder whether the sequence of the bargaining is important or not. From Manning I conclude that if $\mathrm{p}=\mathrm{q}$, then the sequence is not relevant, since then the efficient bargain model holds and the 
Table 3.2 A classification of wage/employment bargaining models

\begin{tabular}{|c|c|c|}
\hline $\begin{array}{l}1 \mathrm{p}, \mathrm{q} \\
\text { with } \mathrm{p} \neq \mathrm{q}\end{array}$ & $\begin{array}{l}\text { Manning } \\
\text { sequential bargaining (wage- } \\
\text { employment bargain) }\end{array}$ & $\begin{array}{l}\max _{W}\left\{U(W, L)^{P} \cdot V(W, L)^{I-p}\right\} \\
\max _{L}\left\{U(W, L)^{q} \cdot V(W, L)^{I-q}\right\}\end{array}$ \\
\hline $2: p=q=c$ & $\begin{array}{l}\text { McDonald-Solow } \\
\text { efficient bargain/contract curve } \\
\text { equilibrium model }\end{array}$ & $\begin{array}{l}\max _{W}\left\{U(W, L)^{c} \cdot V(W, L)^{1-c}\right\} \\
\max _{L}\left\{U(W, L)^{c} \cdot V(W, L)^{1-c}\right\} \\
= \\
\max _{W, L}\left\{U(W, L)^{c} \cdot V(W, L)^{1-c}\right\}\end{array}$ \\
\hline $\begin{array}{r}3: q=0 \\
0 \leq p \leq 1\end{array}$ & $\begin{array}{l}\text { Nickell } \\
\text { right-to-manage }\end{array}$ & $\begin{array}{l}\max _{W}\left\{U(W, L)^{p} \cdot V(W, L)^{1-p}\right\} \\
\max V\left\{(W, L)^{1}\right\} \\
L \\
= \\
\max _{W}\left\{U(W, L)^{p} \cdot V(W, L)^{1-p}\right\} \\
\text { st } W=R_{L}\end{array}$ \\
\hline $\begin{array}{c}4: q=0 \\
p=1\end{array}$ & $\begin{array}{l}\text { Dunlop } \\
\text { monopoly/labour demand } \\
\text { equilibrium model }\end{array}$ & $\begin{array}{l}\max _{W}\left\{U(W, L)^{1}\right\} \\
\max \left\{V(W, L)^{1}\right\} \\
L \\
= \\
\max \{U(W, L)\} \\
W \\
\text { st } W=R_{L}\end{array}$ \\
\hline
\end{tabular}

If $\mathrm{p}=\mathrm{q}$, however, one basically maximizes a function like the one that is given in equation (3.12). Given that the solution is efficient, this comes down to the efficient bargain model or the contract curve equilibrium model. If $\mathrm{p} \neq \mathrm{q}$, while $0<\mathrm{p}, \mathrm{q}<1$, there is bargaining over wages and employment but the solution is inefficient. This is the class of models that $I$ have not discussed. If $\mathrm{q}=0$, then bargaining is only about wages and

outcome is independent of the sequence in the bargaining process. However, this does not hold for p*q. Unfortunately, one must stick to this general conclusion, because the specific implications of the bargaining sequence for the outcome of the bargain depend very much on the specification of the model. 
model 3 follows. This is the right-to-manage model. Finally if $p=1$ and $q=0$, model 4 shows that the union sets unilaterally the wages taking the labour demand curve into account. As I have explained, this model is known as the monopoly model or the labour demand equilibrium model.

I conclude that the analyses of Leontief and Dunlop have been elaborated extensively. Basically, two basic models are left. In one model, there is only wage bargaining, while in the other model parties bargain about wages and employment. And if one assumes that the bargaining power is the same in the wage and in the employment bargain, the main difference between the basic models is that in the latter type of model, Pareto-efficiency is reached. ${ }^{14}$ This implies that no party cari gain, without harming the other party, by choosing a different wage/employment package than the one that is bargained. ${ }^{15}$ Finally, Table 3.3 summarizes the model specifications and the corresponding solutions.

Note that although the structure of the right-to-manage and the efficient bargain model looks very much alike, there are two major differences. First, the trade-off between wages and employment is part of the right-to-manage solution (it is in $\mathrm{dU} / \mathrm{dW})$. Second, since $\mathrm{L}$ differs between these models, $R(L) / L$ differs too. This is elaborated in the appendix.

14 As I have explained before, Manning showed us that one must add to the two basic models, wage and employment bargains, but where $\mathrm{p} \neq \mathrm{q}$. In empirical research, however, the CEM and the LDEM/right-to-manage model are the competing theories to explain the influence of unions on employment and wages. This research is discussed in section 5 of this chapter.

15 General and partial equilibrium anaiysis: the results that have been presented so far are derived from a partial equilibrium analysis. In an interesting paper, Layard and Nickell (1987) have shown that under rather plausible assumptions in a wage-employment bargain, employment need not be higher than in a wage bargain alone. This conclusion is reached from a general equilibrium analysis in a fully unionized economy. The core of the argument is that if bargaining about wages and employment in every firm takes place, the bargaining environment differs from the situation of wage bargaining only. Whether the contract curve has a positive slope or is vertical, bargaining according to the contract curve either means a higher wage at given employment or higher employment at given wages (relative to a solution on the demand curve). This implies that outside opportunities differ from a situation in which bargaining is about wages only. The difference is that in an efficient bargain the risk of unemployment at each wage level is smaller because the bargain is about employment as well. Or, the chance of getting a job at a certain wage rises when bargains are efficient. This influences the union's indifference map. According to Layard and Nickell it is not correct (in a general equilibrium analysis) to use the same location of the union's indifference map: the map shifts to the north. The final result is then not clear in advance. 
Table 3.3 A Classification of wage/employment bargaining models and the corresponding solutions

\begin{tabular}{|l|l|l|}
\hline \hline type of model & maximization problem & solution \\
\hline $\begin{array}{l}\text { Dunlop } \\
\text { monopoly/labour } \\
\text { demand equilibrium } \\
\text { model }\end{array}$ & $\begin{array}{l}\text { max }\{\mathrm{U}(\mathrm{W}, \mathrm{L})\} \\
\text { st } \mathrm{W}=\mathrm{R}_{\mathrm{L}}\end{array}$ & $\mathrm{U}_{\mathrm{L}} / \mathrm{U}_{\mathrm{W}}=-\mathrm{d}\left(\mathrm{R}_{\mathrm{L}}\right) / \mathrm{dL}$ \\
\hline $\begin{array}{l}\text { Nickell } \\
\text { right-to-manage }\end{array}$ & $\begin{array}{l}\mathrm{W} \\
\text { st } \mathrm{W}=\mathrm{R}_{\mathrm{L}}\end{array}$ & $\begin{array}{l}\mathrm{W}=\mathrm{R}(\mathrm{W}, \mathrm{L})^{\mathrm{p}} \cdot \mathrm{V}\left(\mathrm{W}, \mathrm{L}, \mathrm{L}^{\mathrm{rm}}\right) / \mathrm{L} \mathrm{L}^{\mathrm{rtm}}-(1-\mathrm{p}) / \mathrm{p} \\
{[\mathrm{U}(\mathrm{W}, \mathrm{L}) /(\mathrm{dU} / \mathrm{dW})]}\end{array}$ \\
\hline $\begin{array}{l}\text { McDonald-Solow } \\
\text { efficient bargain/ } \\
\text { contract curve } \\
\text { equilibrium model }\end{array}$ & $\begin{array}{l}\mathrm{Wax}\left\{\mathrm{L}(\mathrm{W}, \mathrm{L})^{\mathrm{c}} \cdot \mathrm{V}(\mathrm{W}, \mathrm{L})^{1-\mathrm{c}}\right\} \\
\mathrm{W}=\mathrm{R}\left(\mathrm{L}^{\mathrm{eb}}\right) / \mathrm{L}^{\mathrm{eb}}-(1-\mathrm{c}) / \mathrm{c} \\
{\left[\mathrm{U}(\mathrm{W}, \mathrm{L}) / \mathrm{U}_{\mathrm{W}}\right]}\end{array}$ \\
\hline
\end{tabular}

rtm = right-to-manage;

eb $\quad$ efficient bargain

During the foregoing analysis, the utility functions of the bargaining parties have been kept implicit, although they are at the centre of the analysis. I will now turn to these utility functions.

\subsection{Utility functions and the bargaining solution}

Untill now, I have focussed on the structure of the models, without paying much attention to the utility functions and the bargaining solution. In this section these topics will be discussed. I start with the utility functions and thereafter 1 discuss the bargaining solution that I have used.

\subsubsection{The Union utility function}

In this section I take a closer look at the utility functions of the bargaining parties. Although the union utility function is the core of this section, I start with a short discussion of employers' utility.

\section{Employers' utility}

Notwithstanding the fact that in wage bargaining two parties maximize their utility functions, the literature pays much attention only to union utility. Employers simply 
maximize their profits $(\pi)$ and the employers' utility function can, in general terms, be defined as

$$
\pi=V(W, L) \quad \text { with } V_{\text {PW }}, V_{L}<0
$$

and by using the same assumptions as in section 3.3 .2 the profit function can be given by $(3.15)$

$$
\pi=R(L)-W \cdot L-C
$$

with $\mathrm{C}$ the fixed costs of production.

The production function that is assumed is rather simple. Capital is kept fixed and production is characterized by diminishing returns and depends on labour. CobbDouglas functions or CES production functions fulfil these criteria. Note, however, that by this definition I exclude production functions that incorporate effort as a variable. This is only for reasons of simplicity.

\section{Employees' utiitity}

In the literature, there is hardly any discussion about the concept that both wages and employment are important arguments in the union utility function. A major question is about the way they are incorporated. However, especially the variety in union utility functions that can be found in the literature is enormous. Therefore, I have chosen to focus on the most important types, from which a lot of the functions that one finds in research, can be derived. I will discuss 3 basic types of utility functions (Pencavel, 1991): wage bill maximand/Stone-Geary, utilitarian functions and expected utility functions.

\section{The wage bill maximand}

Leontief already discussed the idea that unions might trade wage increases for increases in employment and consequently both wages (W) and employment (L) have entered the utility functions. The general form of the union utility function (U) then is

$$
U=F(W, L) \quad \text { with } F_{W W}, F_{L}>0 ; F_{W W}, F_{L L}<0
$$

Since there is broad consensus about the arguments of the utility function, the discussion focuses on the characteristics of the function (see also Pencavel, 1991).

Dunlop has used the wage bill as the argument in the union utility function. Hence his utility function can be written as 


$$
U=W \cdot L
$$

and in a model where unions can unilaterally determine the wage rate the use of this function comes down to maximizing the wage bill, with the labour demand acting as a constraint (cf. the labour demand equilibrium model, section 3.3.2). Hence, Pencavel (1991) calls (3.17) the wage bill maximand.

However, it will be clear that this function does not meet the conditions that are imposed on utility functions as in (3.16). For example, the marginal utility of both wages and employment is constant. The next step is then to generalize (3.17) to get

$$
U=W^{\alpha} \cdot L^{\beta} \quad \text { with } \quad 0 \leq \alpha, \beta \leq \mathbb{1}
$$

and it can easily be seen that when $\alpha=\beta=1,(3.17)$ follows from (3.18). Another special case of (3.18) is known in the literature as the Stone-Geary utility function; this can be called the Cobb-Douglas equivalent of the utility function since in this function $\alpha+\beta=1$ and consequently

$$
U=\left(W-W^{*}\right)^{\alpha} \cdot\left(L-L^{*}\right)^{(1-\alpha)}
$$

is the Stone-Geary utility function. Note that in a Stone-Geary function a reference wage/employment level is incorporated (denoted by $\mathrm{W}^{*}$ and $\mathrm{L}^{*}$ respectively). One can think of outside opportunities or minimum requirements as an approach for these reference levels. Stone-Geary utility functions with $\alpha=1$ are often used in right-tomanage or similar models (Nickell and Andrews (1983), Holden (1988), Muysken and Van Veen (1996a)). If the rent for the employees is defined as the difference between the union wage and the opportunity wages (multiplied by employment) one sees that if $\alpha=1$ and $L^{*}=0$, the Stone-Geary function nests rent-maximization (Farber, (1986)).

\section{Utilitarian utility functions}

A major problem with wage bill maximand functions is the lack of relation of these functions to individual preference functions. In contrast, the class of utilitarian functions is derived from individual preferences (Farber (1986), Pencavel, (1991)). A utilitarian utility function is the sum of the individual utility functions. Note however, that in the individual utility function hours of work (h) is traded for wages; hence the utility function for the $\mathrm{i}$-th member reads $\mathrm{U}_{\mathrm{i}}=\mathrm{G}_{\mathrm{i}}\left(\mathrm{W}_{\mathrm{i}}, \mathrm{h}_{\mathrm{i}}\right){ }^{16}$ For example, if one aggregates the utility of the $M$ members of the union one gets

16 Whereby $\mathrm{G}_{\mathrm{W}}>0 ; \mathrm{G}_{\mathrm{WW}}, \mathrm{G}_{\mathrm{h}}, \mathrm{G}_{\mathrm{hh}}<0$. 


$$
U\left(W_{1}, W_{2}, \ldots . ., W_{M}, h_{1}, h_{2}, \ldots . ., h_{M} ; M\right)=\sum_{i=1}^{M} G_{i}\left(W_{i}, h_{i}\right)
$$

with $U(\quad)$ is the union utility funetion and $M$ is fixed.

One can also take the product of the utility functions of the members. However, taking logs thereafter (3.20) will return.

If all union members have different preferences, (3.20) is difficult to use in a wage bargain analysis. However, if it is assumed that all union members are identical, that hours of work are exogenous, and that differences in non-wage income may be ignored, (3.20) can be written as

$$
U(W, h)=U(Y)=G(Y) M
$$

where $\mathrm{Y}=\mathrm{Wh}$. Now suppose that not all members are employed, but that one can distinguish between employed $(E)$ and unemployed members $(M-E) .{ }^{17}$ Then one can rewrite (3.20) to get

$$
U(Y, E)=E G(Y)+(M-E) G(u b)
$$

where $\mathrm{ub}$ is equal to the unemployment income. Hence (3.22) expresses that total union utility is equal to the sum of the utility of the employed and of the unemployed members. Note that if membership and unemployment income are exogenous, maximization of (3.22) comes down to rent maximization.

\section{Expected utility functions}

If one assumes in (3.22) that membership and unemployment income are exogenous, one can derive the utility per member $\operatorname{Um}($ ) as

17 Note that $\mathrm{M}-\mathrm{E}>0$ is implicitly assumed. 


$$
\begin{gathered}
U m(Y, E)=G(Y) E / M+G(u b)[(M-E) / M] \\
\text { with } \quad U m(Y, E)=U(Y, E) / M
\end{gathered}
$$

Expression (3.23) is called an expected utility function (Farber, 1986), since it calculates the expected utility for an individual union member. This expected utility consists of a weighted average of wage income and unemployment income, with the weights being the respective probabilities that a union member gets employed or unemployed.

How can one finally characterize union utility functions? I started with the wage bill maximand and ended up with the expected utility function. It is obvious that the treatment of unemployment and the alternative income is a major difference between these functions. In the wage bill maximand and in particular in the Stone-Geary function, unemployment is only implicitly incorporated in the weights that are attached to wages and employment. Unemployment and unemployment income are explicitly incorporated in the utilitarian and in the expected utility function.

Note further that, given the characteristics of the preference function, I assume that unions are risk averse.

\subsubsection{Risk aversion and the bargaining solution}

After the discussion of the models and of the employers' and employees' goals, I will discuss two items that are closely related to these subjects. The first is risk aversion. In a lot of papers union utility functions are related to some kind of risk taking behaviour, often without making clear what the effect of this behaviour is on the outcome. Second, in economics literature the Nash bargaining solution is most often used. One may ask why and whether or not any alternatives are available.

One can measure risk-aversion by the Arrow-Pratt measure of absolute risk aversion (Varian, 1984). This measure is calculated by dividing the second derivative of the union utility with respect to wages by the first derivative (eventually multiplied by the wage rate to get the relative risk aversion). If one calls this measure $S(W)$, one defines $S(W)=-U_{W W} / U_{W}$. Further, if $S(W)>0$ unions are risk averse, if $S(W)=0$ unions are risk neutral and if $\mathrm{S}(\mathrm{W})<0$ unions are risk loving. One can easily show that a concave utility function implies risk aversion. This risk aversion implies, in economic terms, that unions only want to lower their wage further when the amount of employment that they receive in return increases. For example, according to the previous specifications, the Stone-Geary function shows risk aversion, while the wage 
bill maximand implies risk neutrality. Sometimes risk aversion is related to the slope of the contract curve, but it seems to me that the precise relation depends on the specification of the utility function. In case of McDonald and Solow (who use an expected utility function), the existence of risk aversion is a necessary condition for a positively sloped contract curve (a similar result is concluded in Layard and Nickell (1987), but in general the existence of risk aversion does not "guarantee" a positively sloped contract curve. Pencavel (1991), for example, shows that in case of a Stone Geary utility function as $(3.19) \alpha /(1-\alpha)<1$ (hence $=\alpha<0.5$ ) results in a positively sloped contract curve.

In the previous sections, I have discussed wage/employment bargaining, without discussing some kind of bargaining process. The process was described by a bargaining solution. This is called axiomatic bargaining theory (Nash (1950; 1953), Raiffa (1982), Rubinstein (1982), Binmore et.al. (1986), Van Damme (1990), Peters (1992), Thomson (1994)). To be more precise, the Nash solution is axiomatic bargaining theory and it is a solution concept for cooperative games. Axiomatic implies that it is not the bargaining process as such that is analysed, but rather that a solution is characterized. Further, cooperative games are defined as games in which the players can make binding commitments as opposed to noncooperative games in which they cannot (Rasmusen, (1989)). Rasmusen stresses that the game as such is not cooperative or noncooperative, but the way the game is modelled is decisive. In the previous part of this chapter, I have not explicitly assumed that parties can make binding commitments, but implicitly I have discussed cooperative games by assuming that the union will not change their wage demand after employment has been set by the employer. Nor will employers review their decisions after the wage bargain. It follows that in cooperative games parties conclude an agreement which is binding for the parties: they commit themselves to obey the contract. In non-cooperative game theory the only contracts that are credible are self-binding contracts. Note that in these types of games the bargaining process is followed in more detail, since it discusses the course of the game.

An important characteristic of axiomatic bargaining theory is the assumption that players are rational and fully informed about each other's preferences. Then, an interesting question arises: what bargaining solutions are feasible in a certain bargaining model? Since it is assumed that if a feasible bargaining solution is imposed on the game parties will immediately "reach" this solution, the focus is on the solution and not on the process. To take a closer look at the bargaining solution that I have discussed, recall the right-to-manage and the efficient bargain model. There, to calculate a solution, I have maximized the product of the utility functions of the 
bargaining parties. This solution is called the Nash bargaining solution. This solution is often used in labour economics, because of its attractiveness. I will elaborate on this below.

In two famous articles Nash has developed his concept (Nash, 1950 and 1953). Basically Nash asks himself what characteristics for a solution would be reasonable to describe a solution of a game in which two rational and fully informed parties must bargain about a division of a fixed revenue. Note in between that this is normative and not positive theory. Nash assumed that 4 characteristics are important. First, the solution must be Pareto-optimal. If not, the solution is Pareto inefficient and gains for both parties can be earned. Second, if bargaining skills are equal, the solution must be symmetric i.e. both parties receive the same amount of utility from the bargaining. Or in a broader sense: "if the description of the bargaining game does not contain any information that enables a meaningful distinction between the players, then the solution should not distinguish between the players either" (Peters, 1992, p. 14). Note that if the symmetry condition is left out, the asymmetric Nash solution follows. Third, the solution must be invariant to the scale in which utilities are measured, and fourth, irrelevant alternatives must not influence the solution. ${ }^{18}$ It then turned out that calculating the product of the parties" utility functions provides a unique solution that obeys these 4 characteristics.

The Nash solution is one of the possible solution concepts. Thomson distinguishes 9 solution concepts in these type of games, of which 3 play an important role: Nash, Kalai-Smorodinsky and the egalitarian solution. Now the basic point is in a famous theorem (see for example Thomson (1994), theorem 1, p. 1247): The Nash solution is the only solution satisfying Pareto-optimality, symmetry, scale invariance and independence of irrelevant alternatives.

Since the Nash requirements seem very logical to economists and because the Nash solution is rather simple to calculate, the Nash bargaining solution is the most widely used solution concept in wage bargaining models. ${ }^{19}$ However, the relation between this solution and the bargaining process remained a point of discussion. In this respect it is interesting to mention the contribution of Zeuthen (1930). He developed a Nash solution avant-la-lettre. According to Farber (1986): "An early determinate

18 It will be obvious that in the so-called Nash programme of research, these characteristics are heavily discussed. I will not go into these discussions but for the interested reader I refer to Raiffa (1982), Peters (1992) and Thomson (1994), among others.

19 One must not confuse the Nash solution with the Nash equilibrium: the Nash equilibrium is a non-cooperative equilibrium like the solution of the labour demand equilibrium model, while the Nash solution results from bargaining and is a cooperative equilibrium. 
solution (for the bargaining problem in bilateral monopoly) (..) is that proposed by Zeuthen $(1930) .{ }^{20}($.$) This solution is based on the notion of sequential concessions$ made by the parties until agreement is reached. The key to the model is an ad hoc process that determines which of the two parties will concede at any point. (..) The solution has the property that it maximizes the product of the incremental utilities (difference between the utility of the proposed settlement and the utility of the threat point solution) of the parties). (..) The solution is identical to the axiomatic model of bargaining outcomes derived by Nash $(1950 ; 1953)$ so that Zeuthen seems to provide a process justification for the later "rigorous' Nash model" (Farber, p. 1055). Hence the Nash solution is sometimes called Nash-Zeuthen solution. Another important contribution on this very point is a seminal article by Binmore, Rubinstein and Wolinsky (1986) which builds on Rubinstein (1982). In this influential article they explicitly discuss the relation between the Nash solution and solutions of noncooperative games. They first show that, in case the bargaining process is driven by the parties impatience to reach an agreement or by the parties fear that an agreement will not be reached, the solution of the dynamic bargaining process approaches the Nash bargaining solution. Second, they argue that differences in time preference and in attitudes towards risk will imply an asymmetric solution and hence cause a difference in bargaining power. Hence, they conclude that the Nash solution can be related to, in their terms, strategic bargaining games, i.e. games that model the bargaining process explicitly.

\subsection{Empircal research}

The conclusion of section 3.3.5 is that two basic types of models are left: on the one hand the monopoly/right-to-manage model and the efficient bargain model on the other. Empirical research concerning the question which of the two competing models is more relevant in a particular context is rather scarce. In this section I will review some available material, which concerns one of the two models as well as comparisons of the two models. I focus on the LDEM, RTM and CEM models. This implies that I do not discuss here an interesting wage-bargaining model that was developed by Brandsma and Van der Windt (1983) and elaborated by Knoester and Van der WIndt (1987). I refer to chapter 8 for a discussion of these models.

20 The full reference is F. Zeuthen (1930), Problems of monopoly and economic warfare, London, Routledge and Kegan Paul. 


\subsubsection{The labour demand equilibrium model and the contract curve equilibrium model compared}

MaCurdy and Pencavel (1986) provide an explicit test between the models outlined in section 3.3, for the newspaper industry and the International Typographical Union. Basically, they use the idea that in the efficient bargain model, the wage rate is on the contract curve (assuming that unions care about employment). Recalling the equation for the contract eurve, equation (3.11), one sees that this equation nests the monopoly model: if $\mathrm{LU}_{\mathfrak{L}} / \mathrm{U}_{\mathrm{w}}=0$, the monopoly model holds. This point is elaborated by MaCurdy and Pencavel. They develop a production function for the newspaper industry and specify union preferences. From this framework they derive an expression for wages that nests the labour demand equilibrium model as a special case. Then the parameters of this equation are estimated and from the results one can discriminate between the two models. ${ }^{21}$ Hence, MaCurdy and Pencavel in fact test whether the wage rate is on the contract curve or not. As they say, this does not necessarily imply that the contract curve equilibrium model is to be preferred to the monopoly model, but the test "does provide some information suggestive about whether a contract curve equilibrium model might apply" (see also Manning's class of models where wages are not on the labour demand curve and the solution is not efficient). The model is estimated with data concerning members of the International Typographical Union and the daily newspapers for 13 American towns in various years from 1945 to $1973 .{ }^{22}$ The conclusions from the research of MaCurdy and Pencavel are formulated very carefully, but from their analysis it follows that the results provide solid evidence against the labour demand equilibrium model. Moreover, the results are generally consistent with the contract curve equilibrium model.

Brown and Ashenfelter (1986) use data from the same industry and the same union to test the efficiency of employment contracts. Again, they start from the idea that if the monopoly model holds, the wage rate equals the marginal revenue product of labour. If efficient bargaining holds, however, this equality does not hold since the wage is on the contract curve. This is in accordance with the models that have been discussed in the previous sections. Recalling equation (3.11), it was derived that along the contract curve

21 For sake of completeness, it must be said that their estimates cover various types of utility functions (Stone-Gieary, quadratic preferences) and production functions (Cobb Douglas, Translog).

22. Note that data from this union and this industry is also used by Dertouzos and Pencavel (1981), Pencavel (1984) and Brown and Ashenfelter (1986) in their research about wage bargaining. However, MaCurdy and Pencavel have for various reasons composed a new data set, covering the same union and the same industry. To quote MaCurdy and Pencavel: "(..) we collected a completely fresh data set and restricted it to relatively small union locals" ( $\mathrm{p} . \$ 14 / 15$, note 10). 


$$
R_{L}=W-L \frac{U_{L}}{U_{W}}
$$

Hence, Brown and Ashenfelter argue that the test is whether the employment level depends on the wage rate or not. If it does not depend on the wage rate, the level of employment must depend on another variable and Brown and Ashenfelter argue that the alternative wage is a good candidate. ${ }^{23}$ Within this framework, Brown and Ashenfelter make a distinction between strong efficiency, weak efficiency and inefficiency of union/employer contracts. In strong efficient or Pareto-optimal contracts, the marginal revenue product of labour is not equal to the wage rate, but to the opportunity costs of employees. These costs can consist of alternative wages or alternative employment possibilities. If, however, unions can unilaterally determine the wage rate, employers can only adjust employment according to the maximum profit rule. In this case, employment is determined by the contract wage. These contracts are called inefficient contracts. Finally, if both the contract wage and the alternative wage determine employment, weak efficient contracts are realized. Hence, the question is whether employment is determined by the wage rate or by the alternative wage (being a proxy of the opportunity cost). ${ }^{24}$ Their test of contracts consists of two parts. In the first part they discuss results from laboratory bargaining experiments conducted in the early sixties. The results of these experiments show, that when bargaining takes place jointly over price and quantity, the outcome very closely approximates the Paretooptimal solution. The Pareto-efficient value is lost, however, if one party acts as a price leader while the other party adjusts the quantity. In the second part, Brown and Ashenfelter develop a framework that permits the testing of the efficiency of employment contracts. From the foregoing, it is clear that the role of the alternative wage is crucial in their analysis. Estimating an employment relation with contract wages, alternative wages and the lagged dependent variable as explanatory variables does not give satisfactory results. Insignificance and unexpected signs are the main

23 It is obvious that if the utility function is defined in terms of $W$ and $L$ only, employment depends on the wage rate solely. This follows from (3.24). But if a Stone-Geary function is used, then the reference levels of the wage rate (say the alternative wage) and of the employment level enters in equation (3.24).

24 I have elaborated on their ideas somewhat because I wanted to show that the criticism by MaCurdy and Pencavel that the fact whether employment is determined by the contract wage rate or the alternative wage rate is not in general a decisive test to distinguish between the monopoly or the labour demand model, is correct. This is only a good test if the alternative wage is incorporated in the utility function. 
problems. Next they incorporate in their model, apart from the alternative wage, alternative employment possibilities. The results show that if alternative employment possibilities rise, employment in the newspaper industry decreases. This is consistent with the efficient contract hypothesis. However, the relation between the contract wage and employment as well as the relation between the alternative wage and employment are still not convincing. If anything is concluded, both contract wages and alternative wages influence employment. They conclude that "Our interpretation of the ITU data therefore, is that strong efficiency does not seem to be present, but weak efficiency cannot be rejected. We therefore cannot reject the null hypothesis of Pareto-efficiency in employment determination" (S77).

\subsubsection{The right-to-manage model and the labour demand equilibrium model.}

Nickell and Andrews (1983) developed the right-to-manage model. In their model, profits and union utility depend on wages and employment and the bargaining solution is the Nash solution. This solution is then transformed into empirically estimable equations for employment and wages. They use annual data for the United Kingdom from 1951-1979 and the results show that the underlying model gives a satisfactory explanation of the development of wages and employment. From the results it can also be concluded that unions have had a detrimental effect on employment. According to Nickell and Andrews this effect can be avoided if unions and employers bargain simultaneously about employment and wages.

Carruth and Oswald (1985) test two versions of the labour demand equilibrium model for the coal miners' wages (1950-80). The first version is the model as outlined in the preceding part of this chapter. The second version is based on intertemporal optimization against a partial adjustment scheme for labour demand. This means that the union maximizes discounted utility, resulting in a wage path. The results of this model are "distinctly better" than those of the static optimization model. The results show that labour demand is indeed a constraint for the union.

The labour demand equilibrium model is also estimated by Dertouzos and Pencavel (1981). Their model is applied to the International Typographical Union and the newspaper industry. They conclude that this model is able to characterize the wage-employment situation in this industry. This means that the ITU does care about wages and employment and that the union in maximizing a utility function is constrained by the employer's labour demand function.

Hersoug, Kjaer and Rodseth (1986) developed a model that permits them to test the labour demand equilibrium model. They chose this model because this models fits best in the institutional framework in Norway. Their method is based on the development of a utility function for the union. In this function, real disposable wages 
and employment are the arguments. The trade-off between the arguments in the utility function is derived from the union's conjectures about the relation between prices and wages and employment and wages. The estimates (annual data from Norway, 1960-80) show that the model fits reasonably well. The estimates of individual parameters are, however, rather unreliable and are in some cases not of the expected sign. Part of this result is due to shifts in some major variables. They conclude "After all, we find the results sufficiently encouraging that the main ideas may be worth pursuing further."

One of the reasons that the model of Hersoug et al. gives some unreliable results may be that they apply microeconomic theory to macroeconomic data. Pencavel (1985) is one of the few papers that explicitly deals with the kind of problems that accur in such a case. The heterogeneity of the parties involved in wage determination together with the difficult-to-capture institutional framework causes serious aggregation problems. However, notwithstanding these problems, Pencavel (1985) also applies the labour demand equilibrium model to aggregate data. His model is estimated with data from the manufacturing and mining sector of the Swedish economy over the 15 years from 1968 to 1982 . From the results of the estimates Pencavel concludes "As they stand at the moment, the results are hardly strong endorsement of the particular model proposed".

Finally, from the research of Svejnar (1986), based on data covering 12 major unionized companies during the mid 1950s and late 1970s in the USA, it can be concluded that the monopoly model cannot be accepted. The bargaining solution lies on some sort of contract curve.

\subsubsection{Conclusions}

The interest in wage bargaining models and in union utility functions increased in the late seventies and the early eighties. The foregoing sections reviewed the main developments that have taken place and I will draw three conclusions.

First, although it has been shown that the monopoly model does not generate Pareto-efficient outcomes with regard to wages and employment, one cannot conclude that the model is therefore not used or valid in practice. The monopoly model is still supported by a lot of empirical evidence.

Second, empirical evidence also shows that the contract curve equilibrium model cannot be rejected in advance. The argument of Nickell and Andrews that employers do not want to bargain about the level of employment is not necessarily true as empirical evidence for the United States shows.

Third, the level of analysis (firm or aggregate level) seems to play a role in the application of the models presented and in the interpretation of the ambiguity of the results. Hersoug, Kjaer and Rodseth (1986) explicitly motivate their choice of the 
model with this argument, while Pencavel (1985) warns for the fallacy of composition that might occur when micro-derived functions are estimated with macro data. The same might be true for the difference in organization and the culture of the union and the firm.

\subsection{Evaluation and comments}

This section comments upon some elements of the models presented in order to highlight some specific characteristics incorporated in the theory behind these models. As follows from the analysis in section 3.3, the difference between the labour demand equilibrium model and the contract curve equilibrium model comes down to the possibility to bargain about both wages and employment. In the words of Nickell and Andrews (1983): will firms retain the "right to manage" and set employment unilaterally or not? The evaluation starts with this point. Thereafter the assumed union utility function is discussed shortly.

\subsubsection{Employment contingencies}

Are parties willing to bargain about employment? In my view this may depend on the level on which bargaining takes place. If bargaining takes place in two stages, the first stage being the central or nationwide level and the second being the branch or the firm level, bargaining items may differ per level. At the central level, agreements upon wages may be reached more easily than agreements upon employment. On the other hand, in the Netherlands one can notice that parties are more willing to discuss employment at the central level than at the industry level. This means that in my view the LDEM and the CEM are not competitive in every respect; I will return to this question in chapter 9.

Furthermore, one must realize what it actually means if contracts contain employment contingencies. In this case firms cannot make continuous adjustments to their total level of employment anymore; these have to be bargained about. According to Nickell and Andrews (1983) this may be a strong reason for firms to bargain only about wages.

Related to this point, in an interesting contribution Hall and Lilien (1979) discuss efficiency of wage bargains both under certainty and under uncertainty about "outside events". Their model is close to Leontief's in that they also use the wage bill instead of the wage rate. The firm's profit $(\pi)$ is defined as $\pi=\mathbb{R}(L)-B(B=$ wage bill) and unions care about income (B) net of the opportunity cost of the time devoted to work $(V(L)): U=B-V(L)$. In an efficient contract, $R^{\prime}(L)=V^{\prime}(L)$ : the marginal revenue product of labour is equal to the marginal opportunity cost of work ( $\left.\mathrm{V}^{\prime}(\mathrm{L})\right)$. If 
employers are free to set employment and if they show profit maximizing behaviour, they equalize $R^{\prime}(L)$ to the wage rate $(W)$ and if $W$ differs from $V^{\prime}(L)$ contracts are not efficient. This results in the theorem that if employers can decide unilaterally about the level of employment, contracts are only by coincidence efficient. But if employers prefer deciding about employment unilaterally, Hall and Lilien ask "whether there are contractual arrangements that achieve efficiency while permitting unilateral profit maximization by the firm"(p. 869). Hall and Lilien argue that if the wage bill is made a function of employment, a number of arrangements can be developed. "Any compensation rule is satisfactory if the marginal cost of labor to the firm $B$ " $(L)$ equals the marginal opportunity cost of labor $V^{\prime}(L)$ at the efficient level of employment" (p. 869/870). The interesting point is that employers can freely set employment such that the marginal revenue product of labour equals the wage rate and yet contracts are efficient. They only need a compensation rule that is contingent on employment. They show that this does not only hold under certainty, but also under uncertainty. In the latter case, one can think of shifts in demand and shifts in the opportunity costs of employment. It needs to be said that this idea has, to my knowledge, not been elaborated in the literature further.

In this respect, a paper of Oswald (1984) is also interesting. On basis of a survey of major trade unions in the United Kingdom and the United States he concludes: "The survey suggests that trade unions do not normally negotiate over the total number of jobs. Although the rate of pay and many of the other factors which impinge on workers' lives are discussed, and often written into the collective agreements, the employer seems to be seen, by both sides, as having the right to set employment unilaterally". Note that this survey was held at the level of the individual firm. Oswald goes on to argue that this does not mean that contracts are not efficient or Pareto-optimal for both parties. For, if efficient contracts are on the labour demand curve, then it does not matter which of the two models is valid (it does not matter from the efficiency point of view). Oswald shows that if layoffs follow the inverse seniority principle (last in, first out), efficient contracts can be on the labour demand curve. If layoffs follow the inverse seniority principle, one can define a median employee (the person with median seniority). Further Oswald assumes that the union utility follows the median voter model: union utility is exactly represented by the utility of the median member. Now the median employee can either be employed or unemployed. If he is unemployed, he is, by assumption, indifferent between specific wage/employment combinations. If, however, he is employed, he maximizes his utility by increasing the wage at such a rate that he will just be employed, i.e. the wage rate will be on the labour demand curve and a Pareto-efficient contract is reached on the 
labour demand curve. Note that if the median employee is employed, he does not care about employment.

The next point that in my view needs attention is the fact that agreements on employment may be very difficult to reach. What should be the dimension of these agreements? Can they be made in terms of total employment or in terms of the capital labour ratio or in terms of crew per machine? In my view, the more heterogeneous a firm is, the more difficult the possibilities for employment agreements are.

\subsubsection{Instability of efficient bargain solution}

If equation (3.11) is recalled, one immediately notices that on the contract curve, the wage rate exceeds the marginal revenue product of labour. Hence, at this given wage rate, employers do not maximize their profit. This creates room for moral hazard and cheating. Figure 3.6 shows the problem.

Figure 3.6 The instability of the efficient bargain solution

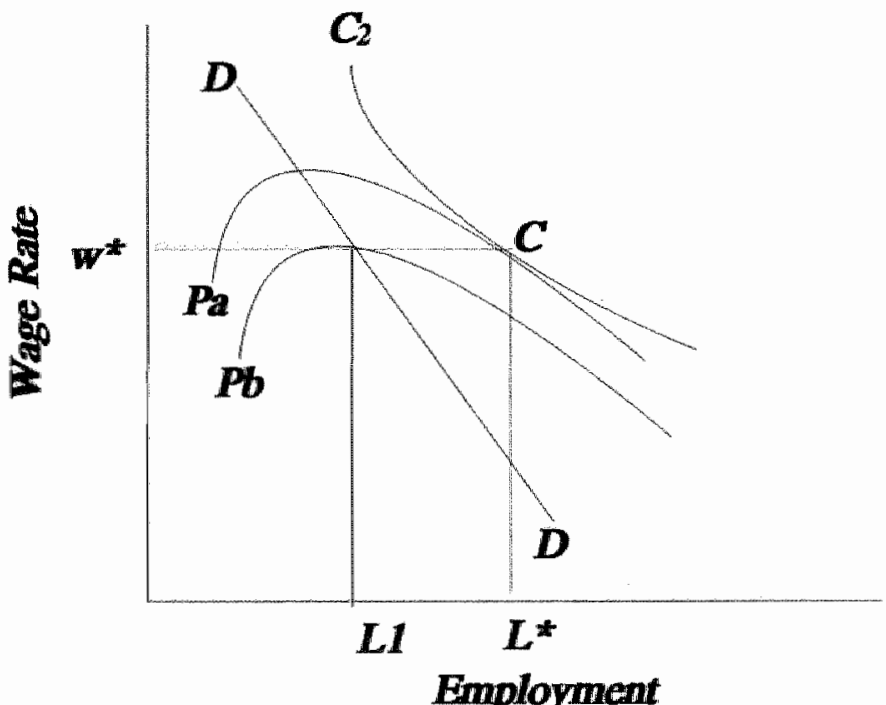

In this figure, $\mathrm{DD}$ is the labour demand curve, $\mathrm{Pa}, \mathrm{Pb}$ are iso-profit curves and $\mathrm{C} 2$ is an iso-utility curve. Suppose that parties agree on a wage/employment outcome $\mathrm{W}^{*}{ }^{*} \mathrm{~L}^{*}$. Then employers have an incentive to try, ex post, to reach an employment level L1, since this increases their profit. Consequently, the efficient bargain solution is unstable or not self-binding. This possibility of moral hazard creates a severe monitoring 
problem for the parties. There are basically two ways to circumvent this problem. First, one can conclude contracts with very detailed conditions about manning, monitoring etc. Second, as Axelrod (1984) has shown, if parties negotiate a number of times, they will discover that cheating is not beneficial anymore, since the opponent will retaliate (see also Abraham, 1989).

\subsubsection{Union utility functions}

With regard to the utility function that is used in the various models, I notice that the arguments of the utility function consist of wages and employment as I have argued in section 3.4.1. ${ }^{25}$ Sometimes wages are taken net of taxes (Hersoug et al. (1986)), sometimes the role of taxes is unclear. In my view, this kind of two-dimensional utility function misses an essential element in the development of the modern welfare state. I mean that the provision of public goods is not dealt with. Is it true that a union will always welcome wage increases even if this happens at the cost of health provisions, unemployment benefits or even sport facilities? In the Netherlands it can be seen in the early eighties that the federation of unions was willing to mitigate their wage demands in order to save the health insurance system.

For an explanation of this kind of behaviour, the work of Mancur Olson (1971) may be relevant. Olson has argued that in small groups the provision of public goods is more likely than in large groups. His theory is based on cost-benefit analysis and claims that if the benefits of a public good exceed the cost for a single member of the group, the good will be provided. The single member is willing to pay for it even if he has to pay for the public good alone. In large groups, benefits have to be spread over many members thus diminishing the benefits of the individual member. ${ }^{26}$

Olson's contribution is worthwhile for wage bargaining models in countries with both centralized and decentralized wage bargaining (multi-level or two-tier wage bargaining). Suppose unions are indeed trading off public goods with wages, under what circumstances can one expect unions to pay voluntarily for the provision of these public goods? According to Olson, one can expect this if small group behaviour prevails. If again it is assumed that wages are settled in two stages and at two levels (central and branch) and apply this to the behaviour of trade unions in wage

25 Moreover, these functions are considered to be stable in time.

26. In the case of pure public goods (goods that are available in the same amount for every member of the group and no member can be excluded from the use) this will not hold. This point is also mentioned by Olson. In his view non-excludability is the distinguishing feature of a public good. If jointness of supply also exists, the good is called a pure public good, but according to Olson "By the definition used here, jointness is not a necessary attribute of a public good" (page 14 , footnote). 
negotiations, one can assume that at the central level, small group behaviour (in the sense of Olson) prevails. This is small group behaviour because the consequences of the actions of the participants are large. If at this level no agreement about the payment of the provision of public goods can be reached, it is unlikely that the goods will be paid for on a voluntary basis. In other words, one cannot shift the payment to other organizations, except to the government. Agreements on voluntary payment for public goods can be expected because the cost-benefit relation is at this level most favourable.

At the branch or firm level, however, large group behaviour is more likely to prevail. In the case of a large number of unions, no single union may have so much interest in the provision of a public good if it paid for its provision alone. At this level unions may try to shift the costs of the provision to other unions. If so, one may hypothesize that for the federation of unions, apart from wages and employment, some measure of public goods is part of the utility function. The federation might in this context be seen as an coordination mechanism. It coordinates in order to minimize externalities. These externalities might occur if only single unions would exist and can be seen as high unemployment and inflation (Abraham (1987); Jacobs and Janssen 1990)). In my view the non-provision of public goods might be an externality as well. I return to this point in chapter 9.

\subsection{Conclusions}

In this chapter I surveyed two models of wage determination in the case of monopoly power in the labour market. It can be concluded that if unions and employers bargain about wages while employment is unilaterally determined by the employers, Paretoinefficient contracts will result if union and firm utility depend both on wages and employment. In order to reach a Pareto-efficient contract, wages and employment must be the bargaining items. Then, however, wages exceed the marginal revenue product of labour.

It is concluded that the empirical validity of these models depend on the institutional framework and empirical results indeed point into this direction. Furthermore I have sketched that problems concerning the relation between taxes, public goods and wages could be incorporated into this framework. 
APPENDLX 3 A closer look at the relation between the monopoly model, the right to manage model and the efficient bargain model:

In this appendix I elaborate on the three solution concepts that were presented in the chapter, to clarify the differences. This appendix is inspired by the analysis of Booth (1995, chapter 5).

I start with Figure $3 \mathrm{~A} 1$, which shows the solution concepts in one picture.

Figure 3Al The relation between the LDEM, the RTM and the CEM

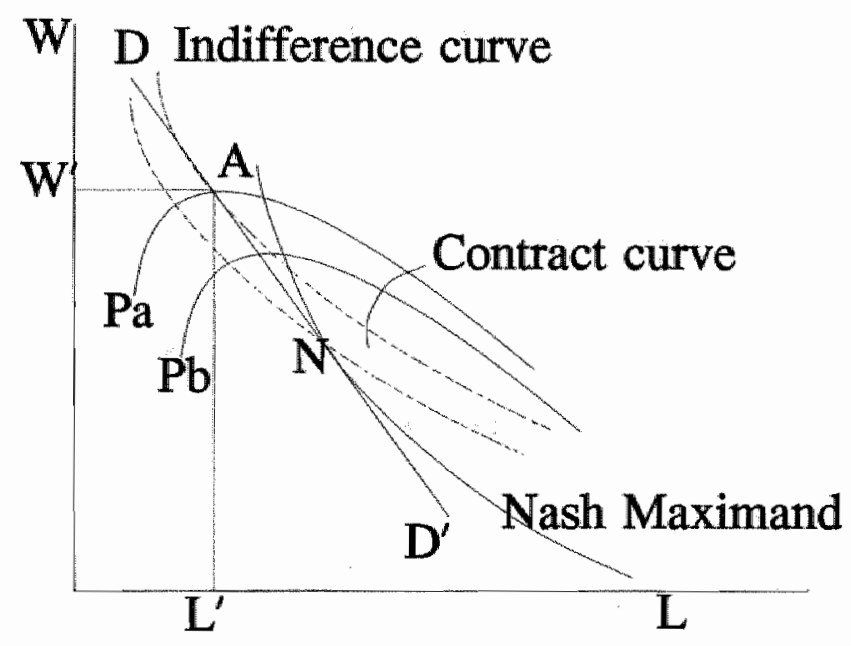

In the monopoly model, the solution is the familiar equality of the marginal rate of substitution between labour and employment for the union, and the rate of substitution between these variables by the employers along the labour demand curve (see equation (3.3) in the main text). This simply comes down to the idea that for a given demand for labour curve (DD'), the unions try to reach the indifference curve that yields the highest utility, see point $\mathrm{A}$ in Figure $3 \mathrm{Al}$.

The same kind of idea is behind the right-to-manage model. However, the equilibrium is now characterized by the point of tangency between the bargained wage curve (in the figure this curve is called Nash maximand) and the labour demand curve, 
see point $\mathrm{N}$ in Figure $3 \mathrm{Al} .{ }^{27}$ The indifference curve now intersects with the labour demand curve. The reason is that because the power over the wages has to be shared between employers and employees the union cannot reach the "highest" indifference curve anymore. Instead, the bargaining results in a bargained wage curve (equation (3.7) in the main text) which shows feasible wage/employment combinations under the restriction that employers determine employment. Of course, the point of tangency of this curve and the labour demand curve is the solution and it can easily be derived that at this point the slope of the bargained wage curve is equal to the slope of the labour demand curve.

In an efficient bargain, the solution is by definition on a contract curve and hence dictates equality of the slopes of the isoprofit curve $(\mathrm{Pa}, \mathrm{Pb})$ and the indifference curve. The major question is: at what point of the contract curve is the solution? This depends on the solution concept that is used. If the Nash solution is used, then the contract curve can be calculated either by equalling the slopes of the indifference curve and the iso-profit curve or by differentiating the Nash maximand to $W$ and to $L$ and equate these partial derivatives.

From $U=U(W, L)$ and $\pi=R(L)-W L$ the Nash maximand is defined

$$
N=U(W, L)^{\lambda}(R(L)-W L)^{(1-\lambda)}
$$

with $\lambda=$ bargaining power and it follows

$$
\begin{gathered}
N_{W}=\lambda U_{W} \pi-L(1-\lambda) U(. .)=0 \\
N_{L}=\lambda U_{L} \pi+L(1-\lambda) U(. .)\left(R_{L}-W\right)=0
\end{gathered}
$$

and from (A3.2) and (A3.3) follows

$$
\frac{L}{R_{L}-W}=-\frac{U_{W}}{U_{L}}
$$

Equation (A3.4) is equal to equation (3.10) in the main text. Hence, an alternative interpretation of the contract curve is that it shows the feasible combinations of wages and employment, given that the Nash solution solves this game. If one next knows the

27 This holds as long as the unions have not full bargaining power. In this latter case the Nash maximand and the indifference curve become identical. 
optimal employment level on this contract curve, the wage rate can easily be determined. The optimal employment level is given by equation (A3.3). So, equal (A3.3) and (A3.4) and one finds the solution on the contract curve.

The curve that relates the optimal employment level to the wage rate (derived from $N_{L}=0$ ) is called the rent-division curve since it divides the rent (the difference between the average product of labour and the marginal product of labour) between the parties. This can be seen when (A3.3) is elaborated

$$
W=\left[\frac{1}{\lambda+(1-\lambda) \frac{U}{U_{L}} \frac{1}{L}}\right](\lambda) \frac{R(L)}{L}+\left[\frac{U}{U_{L}} \frac{1}{L}\right](1-\lambda) R_{L}
$$

According to this rent division curve the wage is the weighted average of the average product of labour and the marginal product of labour. If one chooses next a comfortable utility function, (A3.5) can be simplified further. For example if the utility function is chosen such that $U / U_{L}$ is equal to $L$ then (A3.5) changes in (see also Booth (1995); Ulph and Ulph (1992))

$$
W=(\lambda) \frac{R(L)}{L}+(1-\lambda) R_{L}
$$

and (A3.6) shows more clearly that along the rent division curve the wage is the weighted average of the average and the marginal product of labour.

If one next combines the contract curve and the rent division curve, one finds the wage-employment combination at the point of intersection of these curves. Figure 3 A2 illustrates this, where, apart from the demand for labour curve (DD), iso-profit curves $(\mathrm{Pa}, \mathrm{Pb})$, the average product of labour curve $(\mathrm{Av})$ and the rent division curve (RR) are drawn.

When the Nash solution concept is used for both the right-to-manage and the efficient bargain model, the solutions of these models look very much alike, see Table 3.3. There are two major differences. First, note that employment differs in general between these solutions. Hence $R(L) / L$, the average product, differs. Second, since the right-to-manage model requires that the solution is on the labour demand curve, one explicitly sees the trade-off between wages and employment in the solution. This is not the case in the efficient bargain model, since the solution is not necessarily on the labour demand curve. 
Figure $3 \mathrm{~A} 2$ The contract curve and the rent division curve

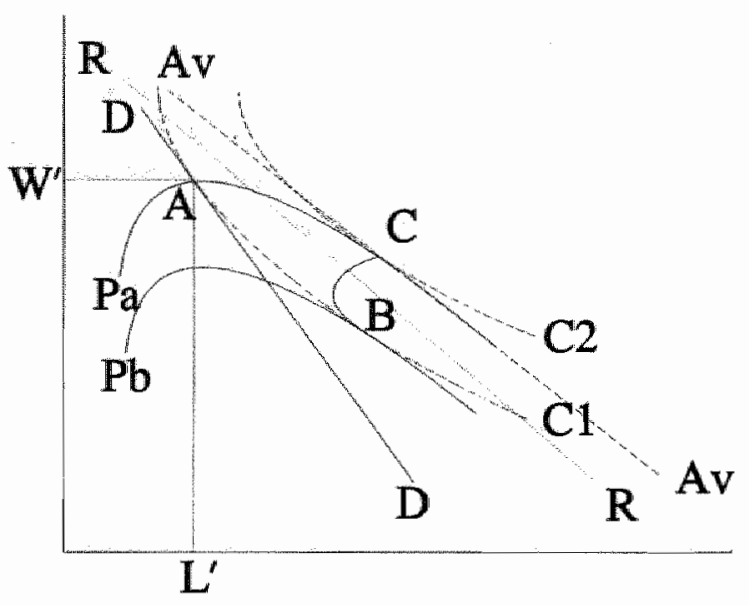




\section{A BARGAINING APPROACH TO WAGE DRIFT*}

1 have concluded in chapter 2 that in addition to wage bargaining, the existence of wage drift is a characteristic of the Dutch labour market The Dutch share this charaeteristic. after all, with most countries in Europe notably the Scandinavian countries and Germany. In this chapter a bargaining model to explain the existence of wage diff in a two-tier wage bargaining system is developed.

Contrary to other models that explain wage drif, the efficiency wage argument as the foundation for bargaining about wage drift is incorporated. As distinct from the view in most bargaining models, where firms and unions struggle for the division of a fixed plece of eake, the relation between wages and revenues is explicitly taken into account The implications for wages and employment appear to be different, not onlly with respect to the order of magnitude, but also in a qualitative sense, in my view, thits model is able to explain first the continuing wage dift that can be seen in the Netherlands during at least the period 19734193 and second the negative relation between the contract wage and wage drift that has been found in empirical research for the Netherlands.

\subsection{Introduction}

In most European countries, wage levels are not solely determined by wage bargaining between a firm (employer) and an employee. Often, there is a contract wage, resulting from negotiations between national or industry unions and employers" federations. Within the firm, (firm) unions or individuals bargain about a mark-up on the contract wage, the wage drift. I have concluded in chapter 2 that the situation in the Netherlands fits into this framework. ${ }^{1}$

Parts of this chapter have been published before in Muysken and Van Veen (1993; 1996a).

1 In chapter 21 have distinguished between earnings drift and wage drift. Earnings drift is the difference between the level of the earned wages and the level of the contract wages, while wage drift is the difference between the changes in the eanned wages and the contract wages (as far as they cannot be explained by the contract). These definitions are based on the Dutch/German tradition. Scandinavian economists are less inclined to make this distinction (Holden (1988), Moene (1988)). Since this chapter is inspired by Holden and Moene, I follow their terminology and discuss the difference between the level of the eamed wage and the level of the contract wage. 
This chapter elaborates on wage drift: how wage drift can be explained and what the relation is between wage drift and the wage that is agreed at the "higher" level are some of the questions that I will address to. Further I will analyse employment at the firm leve]. Since this is not the first contribution that discusses these questions, I start the analysis with a discussion of an often used model developed by Moene and Holden. They assume that wage drift results from a bargaining process between a union and a firm. The rationale for this wage bargaining at the firm level follows from the threat of strikes and goslow actions from employees in case their desired wage differs from the centrally agreed wage. ${ }^{2}$ However, I will argue that the models used by Holden and Moene lack a sound interpretation of the so-called threat point in the Nash bargaining solution and that efficiency wage theory provides a more rigorous argument.

I use this bargaining model and incorporate the efficiency wage argument as the foundation for bargaining about wage drift. Hence, contrary to the view in most bargaining models, where firms and unions struggle for the division of a fixed piece of cake, the relation between wages and revenues is explicitly taken into account. As a consequence, the room for wage bargaining at the firm level follows from the difference between the centrally agreed wage and the profit maximizing wage rate at the firm level. Moreover, I conclude that if efficiency wages are introduced in the models used by Holden and Moene, a quasi-Solow condition appears. Finally, the consequences for employment are analysed extensively. It appears that contrary to the Moene/Holden model, both employment and wages increase when the bargaining power of employers decreases.

The chapter is organized as follows. In the next section I present and elaborate the basic model as it has been outlined by Moene and Holden and point out some flaws in this set-up. Next, in section 4.3, I show how an efficiency wage argument changes the set-up and the conclusions of the model. In section 4.4 both models are compared and section 4.5 ends with concluding remarks.

2 To avoid any misunderstandings: both Moene (The Economic Journal, 1988) and Holden (Scandinavian Journal of Economics, 1988) have developed a model of wage drift, but the underlying mechanisms resemble each other in such a way, that $I$ prefer to call these kind of models the Moene/Holden model. 


\subsection{The Moene/Holden model}

\subsubsection{The bargaining environment}

The aim of Holden (1988) is to analyse local and central wage bargaining within one framework. In his model, two levels of negotiation are involved and wage and employment determination consists of three stages. In the first stage a tariff wage is set by the central union, according to some kind of monopoly model (central level). Next, firms set the employment level (local level). This employment level is constant during the period of analysis. Finally, firms and local unions bargain about wage drift (local level). Two features are characteristic in the model. First, employment is set before bargaining about wage drift. Second, all parties have full information about each other's positions. Finally the asymmetric Nash bargaining solution is imposed upon the game as the solution concept.

It may seem strange that when the tariff wage is determined, parties are aware of the fact that at the local level the tariff wage functions as a starting point in the negotiations. It can be argued, however, that the tariff wage is based on some kind of average. The labour demand function at the central level then represents average marginal productivity. This implies that firms can pay higher wages than the centrally agreed tariff wage. An alternative explanation is that the central union weighs employment against wages, while the local union only cares about wages since employment is determined before bargaining about wage drift. Moene/Holden do not discuss this explicitly, however.

Because of the completeness of information, it is possible to start the analysis with the final stage, the wage drift bargaining process. Here Holden follows the same approach as Moene (1988), and the bargaining environment at the firm level can be characterized as follows. Employers strive after maximization of profits. Ignoring fixed costs, profits are defined as the difference between revenues and wage costs. At the firm level, unions only care about wages since in this framework employment is determined prior to wage bargaining. With respect to firm behaviour, Moene argues that "employment is a long term decision variable of the firm, due to hiring and firing costs, technologically determined manning requirements and long term delivery contracts of the firm" (p. 473). Hence, although the firm has the right to manage employment, it will not change employment continuously. This set-up is therefore neither the strict right-to-manage model, nor the efficient bargain model - this will be elaborated below.

In the bargaining game as described by Moene and Holden, the aim is the distribution of a certain revenue (R) between wage sum (WL) and profits $(\pi)$. The revenue is predetermined because it depends on the amount of labour ( $\mathrm{L}$ ) which is known before 
wage bargaining. The wage will be set according to the generalized Nash bargaining solution. If there is disagreement about the distribution, there are various possibilities: for example, a strike with total stoppage of the production process or "work to rule". Anyhow, one can define some disagreement outcome as those profit and wage levels that will be reached when there is disagreement about the distribution of the revenue, $\pi_{\min }$ and $\mathrm{q}$ respectively. ${ }^{3}$

One can interpret $q$ in many ways. Moene, for example, stresses the fact that $q$ represents the income that will be received if there is no agreement. Depending on what happens in this case, $q$ can be interpreted as the income received during a strike or during go-slow actions, i.e. the disagreement income. According to Holden, $q$ is the wage according to the contract that has been concluded at a higher level than the firm. I will follow the latter interpretation.

Since in case of disagreement the employees will decrease their productivity by way of a strike or "work to rule", the actual revenue will be a fraction $\Omega(0<\Omega<1)$ of the revenue in case of an agreement $(R)$. This implicitly defines $\pi_{\min }$ by $q L+\pi_{\min }=\Omega R$. This idea is elaborated by Holden and I will follow his contribution below.

\subsubsection{The determination of the wage rate and profits}

As indicated above, in the Moene/Holden model the result of the bargaining process is assumed to be the outcome of the asymmetric Nash bargaining model. Employers strive after maximization of profits ( $\pi=R(L)$ - WL) above a threshold $\pi_{\min }$, and workers maximize the difference between the final. wage (W) and the threshold wage (q). The bargaining power is represented by a parameter $c$ : $c=1$ represents full-bargaining power and $c=0$ absence of bargaining power of the employers. Hence, the model of Holden can be summarized as

$$
\begin{gathered}
\underset{W}{\operatorname{Max}}\left[R(L)-W L-\pi_{\text {rain }}\right]^{c}(W-q)^{1-c} \quad 0 \leq c \leq 1 \\
\text { with } \pi_{\min }=\Omega R(L)-q L \quad 0<\Omega<1 .
\end{gathered}
$$

3 Moene (1988) deals with all kinds of possibilities for these threat points. The relevance of this analysis is that he shows that equilibrium wage and employment depend on these points. In other words, it makes a difference what the threats are in case of a conflict. As Moene points out, different bargaining environments are described by assuming different threat points. 
and where employment is predetermined. The production function $R($.$) is assumed to be$ well-behaved. This set-up results in a wage rate and profits given by

$$
W=q+(1-c)(1-\Omega)[R(L) / L]
$$

and

$$
\pi=\pi_{\min }+c(1-\Omega) R(L)
$$

The structure of the solution is easy to understand. ${ }^{4}$ In case of disagreement, employees will work according to working rules and productivity will fall. Then wages and profits add up to $\Omega R(L)$. If parties agree about the distribution of the revenue, however, wages and profits add up to $R(L)$. This exceeds the minimum desirable profits, $\pi_{\min }$, plus the minimum desirable wage sum, $q \mathrm{~L}$. Hence extra payments, $(1-\Omega) \mathrm{R}(\mathrm{L})$ must be granted to either employees or employers or to both parties within the firm. The allocation of these extra payments depends on $\mathrm{c}$, the bargaining power and $\Omega$, the fraction of the normal production that will be realized if there is a disagreement. This is expressed by the markups on minimum wages and profits in equation (4.3).

It may be illustrative to consider the two extreme positions. When all bargaining power is in the hands of the employees $(\mathrm{c}=0)$, the employers are left their minimum profit, while the wage rate is maximized. On the other hand, when employers have full bargaining power $(c=1)$ they will pay a wage equal to $q$, while their profits are maximized.

\subsubsection{The determination of employment}

Because firms know at the beginning of the bargaining period what the wage will be after concluding an agreement, they determine employment by maximizing the profit function, given the wage rate that results from Nash bargaining (hence including the wage drift). Thus employment is determined such that

$$
\underset{L}{\operatorname{Max}} \pi=R(L)-W L \text { with } W=q+(1-c)(1-\Omega)[R(L) / L]
$$

and it follows that in equilibrium

4 Note that throughout this chapter, as in chapter 3 and in chapters 8 and 9 , only first order conditions are allowed for. It is implicitly assumed that second-order conditions for maximization are fulfilled. 


$$
R^{\prime}(L)=q /(c+(1-c) \Omega)
$$

where $R^{\prime}(L)$ is the marginal revenue product of labour. ${ }^{5}$ Basically in solving equation (4.4), this marginal revenue product is set equal to the marginal costs of labour and then equation (4.5) results. However, since these marginal costs are lower than the wage rate, the solution of the model implies that the marginal revenue product of labour is lower than the wage rate. ${ }^{6}$ Hence, it would be advantageous for the firms to reduce the amount of labour, but in this model the trade unions can force the firms off their demand curve. ${ }^{7}$ Thus a kind of rent division curve (I call it a wage-employment curve that denotes combinations of wages and employment that are feasible according to the Nash solution of the game), results with wages higher than marginal revenue.

With respect to the two extreme positions in bargaining power one can see that, in case of an agreement, the right-to-manage model results when the employers have full bargaining power. That is, the wage rate $q$ has been set in negotiations (at a higher level) and the employers then choose employment, $\mathrm{L}_{1}$, such that the marginal productivity of labour equals that wage rate. Thus:

$$
R^{\prime}\left(L_{1}\right)=q
$$

holds.

When on the other hand the employees have full bargaining power, the resulting employment, $\mathrm{L}_{0}$, is given by

$$
R^{\prime}\left(L_{0}\right)=q / \Omega
$$

5 In this chapter I use an 'instead of a subscript to denote a partial derivative: hence $R$ ' ( $L$ ) is equal to what was called $R_{\mathrm{L}}$ in the previous chapters.

6 The marginal costs of labour can be written as $w\left\{1+\epsilon^{w, L}\right\}$, where $e^{w, L}$ represents the elasticity of wages with respect to employment. Since this elasticity is a function of marginal productivity, the marginal costs are not equal to the right-hand side of equation (4.5) - equation (4.5) is a reduced form. This equation is derived as follows: 1) calculate wL from eq. (4.3); 2) take the first derivative from wL with respect to $L_{*} 3$ ) from equalization of the result from step 2) with $R^{\prime}(L)$ equation (4.5) follows. Moreover, since the elasticity of wages is negative as long as average productivity exceeds marginal productivity - which follows from the concavity of the production function - marginal costs will be lower than the wage rate (except when $c=1$, then $\epsilon^{W, L}=0$ ),

7 This is elaborated in Appendix 4. 
It is obvious that $L_{0}$ is smaller than $L_{1}$. And one can see that when the bargaining power of employers increases from $c=0$ to $c=1$, employment increases from $L_{0}$ to $L_{1}$.

The above results are summarized in Figure 4.1. The line $A B$ in this figure represents average productivity, while the line ED represents marginal productivity. The curve indicating the feasible combinations of wages and employment resulting from the negotiation process then is the curve $\mathrm{CD} .{ }^{8}$ This curve divides the average product between wages and profits. It is obvious that the minimum profits per worker are $\mathrm{AC}$ at employment level $L_{0}$. The profits per worker increase with employers' power to the maximum level of $B D$ at employment level $L_{1}$. Simultaneously, the wage rate decreases from $\mathrm{C}$ to $\mathrm{D}$.

Figure 4.1 Productivity and employment in the model of Holden

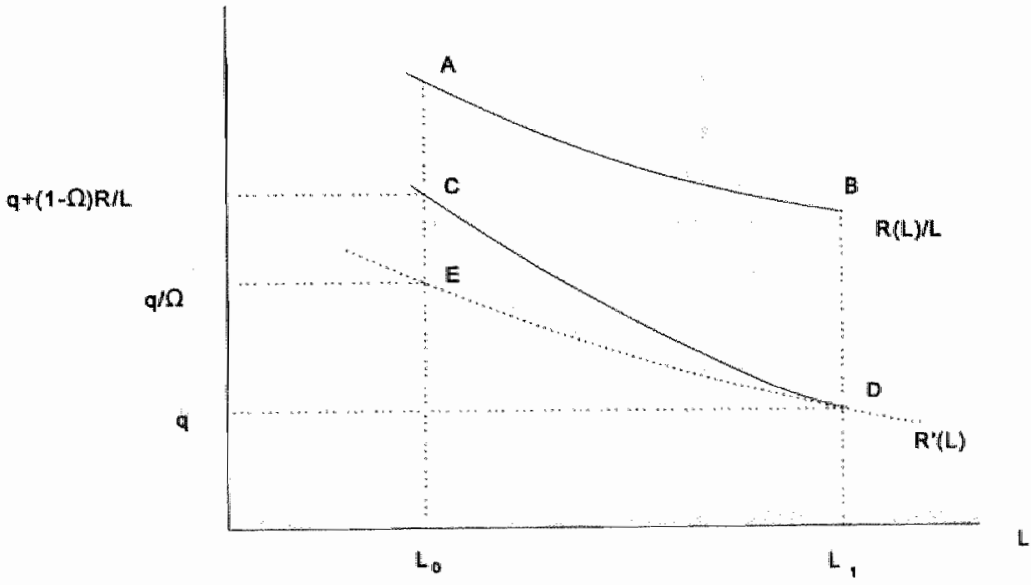

\subsubsection{Evaluation of the model}

Although the Holden model has the attractiveness of having a clear and simple structure, some shortcomings of this model will be discussed now. 
The idea that gives momentum to the model is that if there is no agreement about the wage drift, only part of the possible production will be produced. The fraction of the production is given by $\Omega$. Because of the important role of this variable in the model, it would be interesting to analyse the determinants of $\Omega$. However, in the model $\Omega$ is exogenously determined and hence it is unclear what variables influence $\Omega$. One can expect, for example, that $(\mathbb{1}-\mathrm{c})$ is of influence on $\Omega$. What gives employees the possibility for producing $\Omega R(L)$ instead of $R(L)$ ?

In line with this point the model cannot provide a sound explanation for the monopsony case, in which the wage equals q. In that case there is agreement about the wage, and because of the mere existence of an agreement, workers work at full capacity level $-R=R(L)$ instead of $R=\Omega R(L)$. For unclear reasons, Holden has excluded this case from his model, but let us assume that $\mathrm{c}$ is an infinitesimal part lower than 1 . If an agreement is reached, whereby $\mathrm{W}$ is determined according to equation (4.3), then $\mathrm{W}$ is marginally higher than q. Nonetheless, since there is an agreement, workers are prepared to work as hard as would be the case if $c$ was lower and the wage higher. The model assumes that if there is an agreement, employees are satisfied with the outcome by definition. There is no room for some kind of dissatisfaction with the bargaining outcome as long as the outcome exceeds the threshold value.

A peculiar outcome of the model is that there is a positive relation between the tariff wage and the wage drift. When the tariff wage increases, the final wage increases more than proportional. This is caused by the decrease in employment that follows an increase in the tariff wage. This decrease in employment puts an upward pressure on the total wage (via the increase in labour productivity). This result is peculiar since usually there are only arguments to assume that either the relation between the tariff wage and the wage drift is negative, or that there is no relation between these phenomena (Driehuis (1975), Holmlund (1986), Lever (1993)). It can be negative when the tariff wage and wage drift are substitutes. When wage drift is an independent additive to the contract wage there is no relation between the tariff wage and the final wage. Unfortunately the empirical evidence is scarce on this subject. ${ }^{9}$

Finally, one should realize that the minimum acceptable amount of profits, $\pi_{\min }$, depends negatively on employment, as appears from equation (4.2). Intuitively, however, one would expect a positive relation with both employment and output: it seems plausible that minimun profits are higher at a higher level of output.

In the next section a model is developed that deals with these drawbacks.

9 For the Netherlands Lever (1993) has found a negative relation. 


\subsection{An efficiency wage based model of local bargaining}

The model is related to Moene/Holden in that in this model both central and local wage bargaining exists. Contrary to Moene/Holden, however, an efficiency wage foundation for the explanation of wage drift is used. ${ }^{10}$ In an efficiency wage model, revenue depends on effective labour input. This implies that the amount of labour alone (the number of workers) is not a sufficient determinant of labour output. Apart from the amount of labour, labour effort is important in determining the level of output. Hence, in the production function the amount of labour is multiplied by effort.

An efficiency wage approach is suitable for dealing with the drawbacks of the Moene/Holden model because the core of the efficiency wage theory is that there is a positive relation between the wage rate and the effort of labour. Provided that the contract wage sets the minimum level of wages, the effort consistent with that wage then defines the minimum level of profits in a natural way. Moreover, when the wage decreases because employers have more bargaining power, the effort will decrease too, which expresses the increasing dissatisfaction of the employees.

In line with the analysis above, the analysis starts in section 4.3 .1 with the derivation of the wage rate while employment is given. Then the determination of employment is discussed in section 4.3.2.

\subsubsection{The determination of the wage rate}

As in the Moene/Holden model in section 4.2, the result of the bargaining process is assumed to be the outcome of the asymmetric Nash bargaining model. Employers strive after maximization of profits above a threshold $\pi_{\min }$, and workers maximize the difference between the final wage (W) and the threshold wage (q). The parameter $c$ indicates the bargaining power of the employers. Hence, the problem can be defined as follows:

$$
\underset{W}{\operatorname{Max}}\left[R(.)-W L-\pi_{\min }\right]^{c}(W-q)^{1-c} \quad 0 \leq c \leq 1
$$

10 The approach also differs from Hoel (1989) who analyses efficiency wage based bargaining i) when there are no unions, ii) when there is only central bargaining and iii) when there is only local bargaining. Hence, while Hoel focuses on the appearance of unions in an efficiency wage framework, I analyse the specific characteristics of the introduction of efficiency wages in a local bargaining framework. 
with

$$
\begin{gathered}
R(.)=R[e(W) \cdot L] \\
\pi_{\min }=R[e(q) L]-q L
\end{gathered}
$$

Effort $\mathrm{e}$ is assumed to depend on the wage rate, such that $\mathrm{e}^{\prime} \geq 0$ and $\mathrm{e}^{\prime \prime} \leq 0$ above some minimum level of effort $\mathrm{e}(\mathrm{s})$, while the tariff wage $q$ ensures at least this minimum, i.e. $\mathrm{q}>\mathrm{s}$. Moreover $\mathrm{e}^{\prime}(\mathrm{q})>\mathrm{e}(\mathrm{q}) / \mathrm{q}$ is assumed (I return to this assumption at the end of section 4.3.2). The production function $\mathrm{R}$ is assumed to be well-behaved.

The difference between this set-up and the previous model is that now total revenue depends on both wages and employment. According to equation (4.9a) an increase in wages has a positive effect on effort and consequently on total revenue. Several arguments can be put forward for this relation and I refer to Yellen (1984) for a survey. Because of the positive relation between the revenue for the firm and the effort of the employees, firms can pay a wage that lies above the tariff wage. Thus, contrary to the Moene/Holden approach, an increase in wages need not be reflected in an equal decrease in profits. I will return to this point below.

The minimum profit level, $\pi_{\min }$, is defined as the level that corresponds with an effort of $\mathrm{e}(\mathrm{q})$, that is the effort that prevails when the tariff wage is paid. For instance, in case of disagreement workers will decrease their effort until some minimum level, e(q), that corresponds with the wage $q$ that will be reached in this situation. Contrary to Holden, an exogenous factor $\Omega$ to explain dissatisfaction, is no longer needed. This comes naturally, once efficiency wages are assumed.

The solution to the maximization problem results in wages and profits given by: ${ }^{11}$

$$
W=q+\frac{1-c}{1-\alpha c} \frac{[R(W)-R(q)]}{L}
$$

and

$$
\pi=\pi_{\min }+\frac{c-\alpha_{c}}{1-\alpha_{c}}[R(W)-R(q)]
$$

11 In this section the notation $R(W)$ is used as a short-cut for $R[e(W) L]$. 
The factor $\alpha$ in equation (4.10) is defined by $\alpha=R^{\prime}[e(W) L] . e^{\prime}(W)$ and it will be argued below that $\alpha \leq 1$ holds.

The solution in equation (4.10) corresponds clearly to the Moene/Holden solution in equation (4.3). Again, total wages and profits equal their minimum level plus a markup. The mark-up is proportional to the difference between the revenue when a wage $W$ is paid, and the revenue that belongs to an effort when the wage equals q. Thus, equation (4.10) expresses the idea that an increase in effort is profitable for the firm, but such an increase will only be provided if the wage rate increases. Second, note that the wages depend on $c$, the bargaining power. The higher the bargaining power of the employers, the lower the wages will be at a given level of employment. Third, the bargaining set-up implies that $w \geq q$; hence the wage drift is either zero or positive. Finally, similar comments can be made with respect to profits.

The difference with the Moene/Holden model can be illustrated by looking first at the extreme situations. When employees have full bargaining power $(c=0)$, the wage rate reaches its maximum value $W_{0}$. The mark-up over $q$ then equals $\left[R\left(W_{0}\right)-R(q)\right] / L$. The corresponding mark-up in the Moene/Holden model is $(1-\Omega) . R / L$. Therefore the efficiency-wage model allows to interpret the factor $\Omega$ as: $\Omega=R(q) / R\left(W_{0}\right)$, which seems a reasonable interpretation.

When on the other hand the employers have full bargaining power $(c=1)$, one can determine a profit maximizing wage rate $\left(\mathrm{W}_{1}\right)$ by solving

$$
\underset{W}{\operatorname{Max}} \pi=R(e(W) L)-W L
$$

$$
\text { s.t. } W \succeq q
$$

It then follows that the profit maximizing wage rate can be found when $\alpha=1$, i.e.

$$
R\left[e\left(W_{1}\right) L\right] \cdot e^{\prime}\left(W_{1}\right)=1
$$

This solution is related to the Solow condition in the efficiency wage approach. According to this condition, the optimal efficiency wage is determined in such a way that the elasticity of the effort with respect to the wage is equal to 1 . However, this Solow condition has been derived using the assumption that the employer determines the wage rate and the employment level simultaneously. My model differs from this set-up because 
the employer can only choose the wage rate. Therefore equation (4.12) can be called the quasi-Solow condition. ${ }^{12}$

It is obvious that when $q$ lies below $W_{1}$, employers will set the wage at $W_{1}$ when they have full bargaining power. ${ }^{13}$ And when the employees start to gain bargaining power, the wage will be set higher and the profits will be accordingly lower. It can easily be shown that this implies $\alpha<1$ when $c<1$. Moreover note that $\alpha=1$ holds when $c=1$. Hence $\alpha \leq 1$ holds.

Figure 4.2a Profits and wages in the efficiency wage model

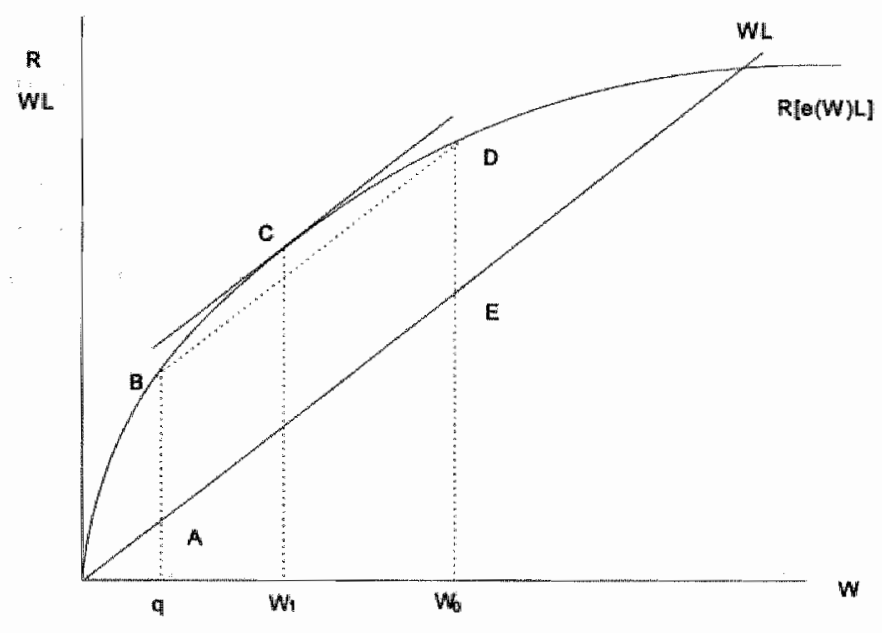

Finally, the above analysis is illustrated in Figure $4.2 \mathrm{a}$. In the figure both revenue and the wage sum are presented as a function of wages for a given level of employment. The minimum profits $\pi_{\min }$ are represented by $\mathrm{AB}$. The wage at which profits are maximal, $\mathrm{W}_{1}$, is found in $\mathrm{C}$. As has already been mentioned above, when the wage increases above

12 What is in a name? However, one can call this a quasi-Solow condition because one of the factors of production is held constant.

13 Hoel (1989) also concludes that if the profit maximizing wage rate exceeds the wage reached througl central negotiations, the firm will wish to give its workers the profit maximizing wage rate. 
$W_{1}$, profits will decrease. This shows up clearly in the figure. It is then obvious that the maximum wage employees can ask, $\mathrm{W}_{0}$, is found when profits have decreased until they reach $\pi_{\min }$. This is represented by $D$ in Figure $4.2 a^{14}$

To compare this with the analysis of Holden, the latter is presented in Figure 4.2b also for a given level of employment. The difference between the revenue in case of a disagreement $(\Omega R)$ and the lowest possible wage sum $(q L)$ is the minimum level of profits. This is represented by $\mathrm{AB}$. From the figure one sees that the wage at which the profits are maximal $(\mathrm{BC})$ is $\mathrm{q}$, the tariff wage. Profits decrease with higher wages and the maximum wage is defined in such a way that profits are at the minimum level, DE.

Figure 4.2b Profits and wages in the Holden's model

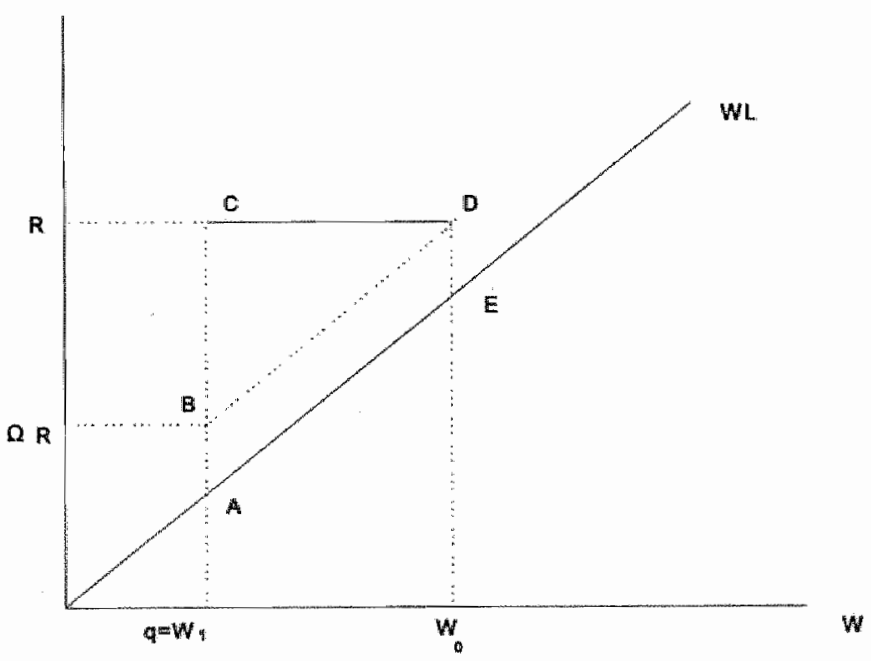

\subsubsection{The determination of employment}

Employers will set employment such that profits are maximized. Taking into account the repercussions on the wage rate, this implies that employment is determined from

$$
\underset{L}{\operatorname{Max}} \pi=R[e(W) L]-W L
$$

14 Obviously $\mathrm{DE}=\mathrm{AB}$ holds. 
with

$$
W=q+[(1-c) /(1-\alpha c)][R(W, L)-R(q, L)] / L
$$

The solution then is given by

$$
e(W) \cdot R^{\prime}\{e(W) L\}=W \cdot \frac{1+\epsilon^{W / L}}{1+\epsilon^{W \cdot L} \cdot W \cdot e^{j}(W) / e(W)}
$$

where $\epsilon^{W, L}$ is the elasticity of wages with respect to employment. The left hand side of equation (4.14) represents the marginal revenue product of labour, whereas the right hand side represents its marginal costs. It is hard to elaborate this equation much further, since $\epsilon^{W, L}$ is a function of $L$ as can be seen from the condition in equation (4.13). One should note, however, that equation (4.14) is equal to the employment condition in the analysis of Moene/Holden when effort is constant and unity, i.e. $e(W)=1$.

In order to gain more insight into the behaviour of employment, the two extreme positions of full bargaining power for employers and employees, respectively, will be analysed. It is obvious that in the case of full bargaining power for employers $(c=1)$ the Solow condition will hold, since then employers will set both employment and wages such that profits will be maximized. That is, the wage $\mathrm{W}^{*}$ will be set such that

$$
W^{*} \cdot e^{\prime}\left(W^{*}\right)=e\left(W^{*}\right)
$$

holds. It then follows from equation (4.14) that the corresponding level of employment, $L^{*}$, is given by

$$
e\left(W^{*}\right) \cdot R^{\prime} e\left(W^{*}\right) L^{*}=W^{*}
$$

This is represented in Figure 4.3. In that figure both wage costs and revenues are depicted as a function of employment, for a given wage rate. For three wage rates $\left(\mathrm{W}_{0}, \mathrm{~W}^{*}\right.$ and $\left.q\right)$ wage costs curves, $W_{0} L, W^{*} L$ and $q L$ respectively, and revenues curves, $\left.R\left\{e\left(W_{0}\right) L\right)\right\}$, $\left.\mathrm{R}\left\{\mathrm{e}\left(\mathrm{W}^{*}\right) \mathrm{L}\right)\right\}$ and $\left.\mathrm{R}\{\mathrm{e}(\mathrm{q}) \mathrm{L})\right\}$ respectively, are drawn. The slope of a wage costs curve is the wage rate, while the slope of the revenue curve is the marginal revenue product of labour. Employers will set employment such that the wage rate is equal to the marginal. 
revenue product of labour. It follows that if the wage rate is $\mathrm{W}^{*}$, the maximum profit, $\pi^{*}$, results at $P$ and employment is $L *{ }^{15}$

When employees have full bargaining power $(c=0)$, employers will only get the minimum acceptable level of profits. This level $\pi_{\min }$ is defined in equation (4.9b) at the wage q. It is obvious then that when the employers have no bargaining power, they will set employment such that $\pi_{\min }$ will be maximized - the resulting employment is denoted by $\mathrm{L}_{0}{ }^{16}$ From equation ( $4.9 \mathrm{~b}$ ) follows that should hold:

$$
e(q) \cdot R^{\prime} e(q) L_{0}=q
$$

This situation is also represented in Figure 4.3. The minimum level of profits is maximal at point $Q$ and consequently $\mathbb{L}_{0}$ is the corresponding level of employment: at any other level the profits are lower, given that the wage rate equals $q$. Since $q$ is assumed to lie below $W^{*}$, the revenues for a given level of employment will be lower compared to the wage $W^{*}$. And it is obvious that employment $L_{0}$ will be higher than $L^{*}$.

Since employees have full bargaining power at employment $\mathrm{L}_{0}$, a wage will be paid that is much higher than the tariff wage and also higher than $\mathrm{W}^{*}$. This wage, $\mathrm{W}_{0}$, can be found by solving $\mathrm{W}_{0}$ from: ${ }^{17}$

$$
R\left\{e\left(W_{0}\right) L_{0}\right\}-W_{0} L_{0}=R\left\{e(q) L_{0}\right\}-q L_{0}
$$

This is illustrated by point $S$ in Figure 4.3. Note that $Q^{\prime}=\pi_{\min }$ and $S V$ equals $Q^{r T}$ at $L_{0}$. Hence the employers are not worse off at $\mathrm{L}_{0}$ when paying $\mathrm{W}_{0}$ instead of $\mathrm{q}$. The level of employment at which profits are maximized, given $W_{0}$, corresponds to point $R$ in the figure, which implies a lower demand for labour. However, as in the analysis of the previous section, employees force the employers off their demand curve for labour.

15 Note that from equation (4.15) and (4.16) it follows that $R^{\prime}\left(e\left(W^{*}\right) L^{*}\right\} e^{\prime}\left(W^{*}\right)=1$; compare equation (4.12).

16 Note that in the analysis of Holden and Moene $L_{0}$ also is set such that $\pi_{\text {min }}$ is maximized - cf equation (4.7).

17 Since $\mathrm{q}<\mathrm{W}^{*}$, there exists a wage rate $\mathrm{W}_{0}>\mathrm{q}$ at which profits are maximal given $\mathrm{L}_{0}$ - compare equation (4.12). That is, given $\mathcal{L}_{0}$ profits will increase when the wage increases from $q$ to $W^{*}$ and will decrease to $\pi_{m i n}$ when wages increase further to $W_{0}$. 
From the above analysis it can be inferred that the demand curve for labour follows the path $P R$ for $W>W^{*}$. This path connects all points where marginal revenue equals the wage rate. However, as in the Holden/Moene case, actual employment is not determined by the demand curve for labour. Actual employment is determined such that marginal revenue equals marginal costs - cf. equation (4.14). When $W \cdot e^{\prime}(W) / e(W)=1$, marginal costs equal the wage rate and marginal revenues too. This corresponds to point $\mathbb{P}$ in Figure 4.3. However, when $\mathrm{W}>\mathrm{W}^{*}$, marginal costs are lower than the wage rate at the optimum level of employment. Hence employment will lie above the demand curve for labour. Moreover, it is derived that when employees have full bargaining power, employment will be represented by point $S$ instead of point $R$. Hence employment will follow the path from $\mathrm{P}$ to $\mathrm{S}$ in Figure 4.3. As a result it also follows that the minimum level of profits increases when employees become more powerful.

Figure 4.3 Employment in the efficiency wage model

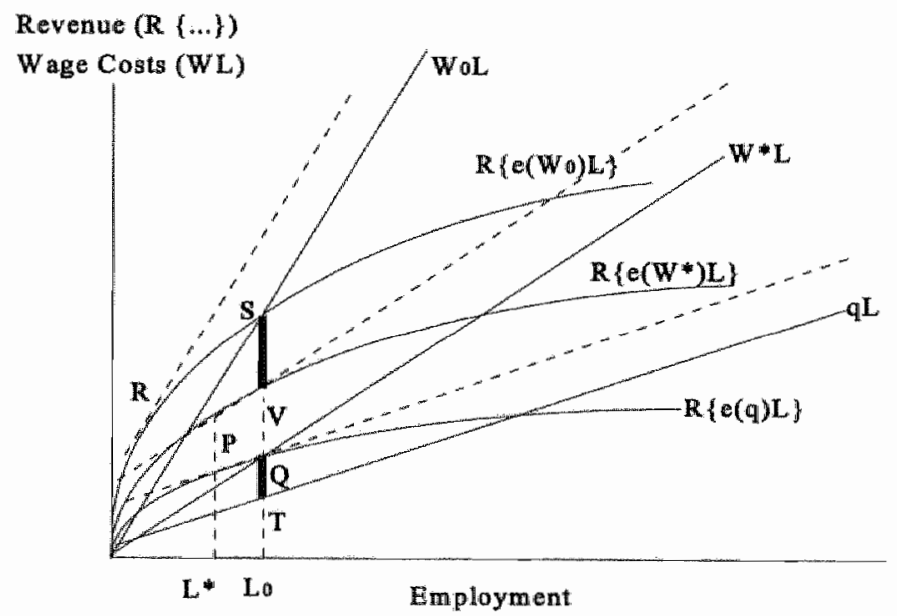

At first sight the result that when employers' power decreases, both employment and wages will increase may seem somewhat counterintuitive. However, one should realize that this occurs at a given level of the tariff wage. If the tariff wage were higher when employees' power increases, which seems a plausible notion, employment would be lower this follows immediately from Figure 4.3 . Hence a negative trade-off exists between the tariff wage and employment at the central level. Such a trade-off is highly plausible and 
it will counteract the increase in employment at the decentralized level. For example, in the 1960 s and the 1970 s one can notice relatively large wage increases and increasing unemployment in the Netherlands, see Table 2.5 for the wage increases. The analysis in this chapter suggests that this (i.e. increasing wages and increasing unemployment) is mainly due to increases in the contract wage. This is indeed suggested by Table 2.5 .

One can present the foregoing analysis in an alternative way which uses some of the concepts that have been developed in chapter 3. When employers have full bargaining power, they will set the level of employment and the wage rate such that both are consistent with profit maximization. The profit maximizing demand for labour at a given wage rate, $L_{1}$, is such that:

$$
R^{\prime}[e(W) \cdot L] \cdot e(W)=W
$$

holds (see also equation (4.16) where this condition has been used before). Equation (4.19) is the demand curve for labour. Next, recall from equation (4.12) that in case of full bargaining power employers will set wages according to:

$$
R^{\prime}[e(W) L] e^{\prime}(W)=1
$$

Equation (4.20) is the so-called wage-offer curve: it is the first order condition from maximizing (4.11) and shows the wage rate that maximizes profits at a given level of employment when $c=1$.

Combination of equations (4.19) and (4.20) then yields the optimal combination of wages and employment which we have denoted before as $W^{*}$ and $L^{*}$ respectively. In this case the Solow condition holds, i.e. the wage rate $W^{*}$ is determined by $\mathrm{W}^{*} . \mathrm{e}^{\prime}\left(\mathrm{W}^{*}\right)=$ $\mathrm{e}\left(\mathrm{W}^{*}\right)$. And $L^{*}$ results from substituting $W^{*}$ in equation (4.19). The assumption $\mathrm{e}^{\prime}(\mathrm{q})>$ $\mathrm{e}(\mathrm{q}) / \mathrm{q}$ ensures that $\mathrm{W}^{*}>\mathrm{q}$.

This situation is depicted in Figure 4.4. In this figure curve the demand curve for labour and the wage offer curve, equations (4.19) and (4.20) respectively, are shown. The (local) concavity assumptions of the functions $\mathrm{R}$ and $\mathrm{e}$ guarantee that the wage offer curve (4.20) is downward sloping. It can also be shown that the demand curve for labour (4.19) is downward sloping around $W^{*}$ and intersects the wage offer curve from above in $W^{*}$, cf. point $P$ in the figure. However, the demand curve for labour is only downward sloping until some wage $W$-below $W^{*}$. At still lower wages it is upward sloping. In the figure it is assumed that the tariff wage $q$ is set above $W_{-}-$hence it is consistent with the 
downward sloping part of the demand curve for labour. The other case will be discussed at the end of this section.

Iso-profit curves are also drawn in the figure. In an efficiency wage framework, iso-profit curves are ellipses, since two wage levels yield the same level of profit, given employment. ${ }^{18}$ Note that the closer the iso-profit curve is to $\mathrm{W}^{*}$, the higher the level of profit is.

Figure 4.4 Wages, employment and profits in the efficiency wage model

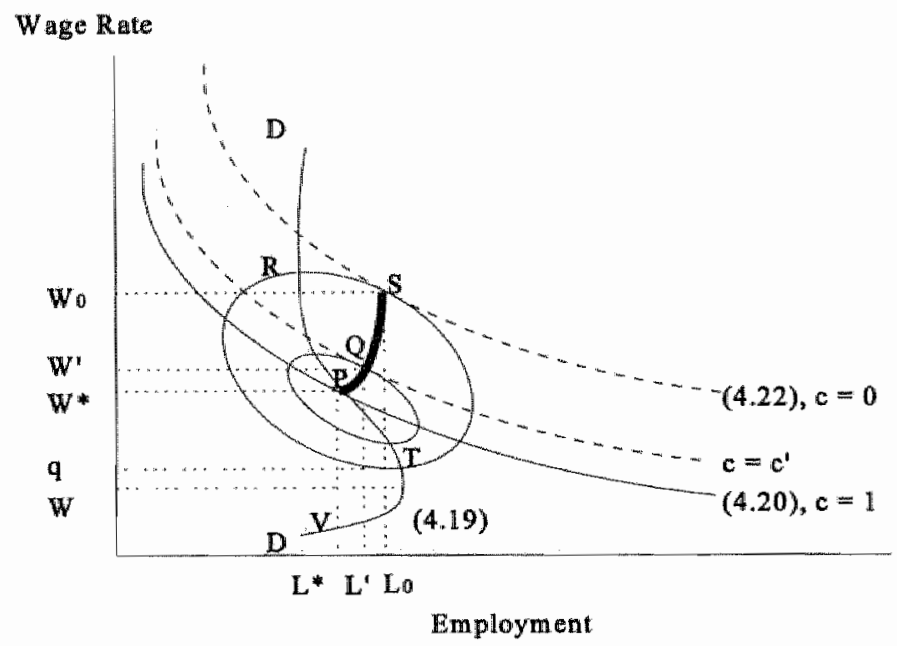

These results imply that if employees gain bargaining power (c decreases), both wages and employment increase. A few steps are needed to elaborate on this. From the discussion above it is obvious that when employers have full bargaining power $(c=1)$ they will set wages and employment according to the Solow condition, cf. point $\mathrm{P}$ in Figure 4.4. That is, $W^{*}$ and $L^{*}$ will result. On the other hand, when employees have full bargaining power $(\mathrm{c}=0)$, employers will only get the minimum acceptable level of profits. This level $\pi_{\min }$ is defined in equation (4.9b) and varies with employment.

I8 By definition both the maximum and the minimum of these ellipses with respect to the $L$ and $W$ axis, respectively, lie on the demand curve for labour (4.19) and the wage offer curve (4.20), respectively. 
It is obvious then that when the employers have no bargaining power, they will set employment such that $\pi_{\min }$ will be maximized - the resulting employment is denoted by $\mathrm{L}_{0}$. From equations $(4.9 \mathrm{~b})$ and $(4.20)$ it follows that

$$
R^{\prime}\left[e(q) L_{0}\right] \cdot e(q)=q
$$

should hold. In Figure 4.4 the maximum of $\pi_{\min }$ is found by the iso-profit curve that is tangent to the profit maximizing level of employment at the wage rate q, i.e. point $T$. Consequently $L_{0}$ is the level of employment that maximizes $\pi_{\min }$. It is obvious that $\mathrm{L}_{0}>\mathrm{L}^{*}$ when $\mathrm{W}-<\mathrm{q}<\mathrm{W}^{*}$, which is assumed to be the case in Figure 4.4.

However, since employees have full bargaining power at employment $\mathbb{L}_{0}$, a wage will be paid that is much higher than the tariff wage and also higher than $\mathrm{W}^{*}$. This wage, $\mathrm{W}_{0}$, can be found by substituting $\mathrm{L}_{0}$ in ${ }^{19}$

$$
R[e(W) L]-W L=R[e(q) L]-q L
$$

In Figure 4.4 this corresponds to the highest wage consistent with profits $\pi_{\min }$ and employment $L_{0}$, which is point $S$. The bargained wage curve at $c=0$ is defined by equation (4.22). ${ }^{20}$ This curve is tangent to the iso-profit curve of $\pi_{\min }$ in point $S$. Hence at this point employers also maximize their profits.

A similar result is obtained when the bargaining power is $\mathrm{c}^{\prime}<1$. Then employers set employment at the point of tangency $Q$ between the bargained wage curve at $c^{\prime}$ and the iso-profit line. The corresponding level of employment is $L^{\prime}$, and the wage outcome will equal W'. Finally, if one combines all points of tangency of the iso-profit curves and the bargained wage curves, one finds the curve PQS. Hence, employers are forced to a point off the demand for labour curve PR. ${ }^{21}$ It now also is obvious that employers will set employment such that $W \geq W^{*}>q$, as was mentioned before.

\section{See footnote 17.}

20 It can easily be shown that this curve is downward sloping - at least above and around point $\mathrm{S}$ and lies above the curve that can be derived from equation (4.19).

21 Note that this result stems from the assumption that employment is determined before wages and is not caused by the efficiency wage argument - see also Holden (1988) and Muysken and Van Veen (1993). 
In Figure 4.4 it is assumed that $W_{-}<q$ holds. However, this is not necessarily the case. Then the results change. It is obvious that wage drift will always occur when $q<W^{*}$, hence also when $\mathrm{q}<\mathrm{W}$-. Only when $\mathrm{q}$ is set far enough below $\mathrm{W}$ - - i.e. below the level at point $V$ in Figure 4.4 - do one find that $L_{0}$ will lie to the left of $L^{*}$. In that case an increase in employers power will lead to an increase in wages on the one hand, but a decrease in employment on the other.

\subsection{Evaluation of the model}

A drawback of the Moene/Holden type of models is the exogeneity of disagreement. In this chapter a modification at this very point has been developed: the exogenous notion of minimum profits, due to slowdown activities or strikes in case of disagreement, is replaced by the notion of efficiency wages. Provided that the contract wage sets the minimum level of wages, the effort consistent with that wage then defines the minimum level of profits in a natural way. Wage drift results automatically to a certain level, because initially both employers and employees have incentives to increase wages above the contract wage. Further, the more bargaining power employees have, the higher wage drift will be. The resulting effort of employees will be higher too, which expresses their satisfaction with the bargained wage. Contrary to models as used by Moene and Holden, an exogenous factor to explain satisfaction or dissatisfaction, is no longer needed. This comes naturally, once efficiency wages are assumed.

When the results of the efficiency wage model are compared with those of Holden, two striking differences can be observed. A first difference is that in the Holden model, employment increases when the power of employers increases, whereas in the efficiency wage model the opposite occurs (as long as the tariff wage is above point $\mathrm{V}$ in Figure 4.4). The different development in employment results from a different reaction to the wage decreases that correspond to a higher bargaining power of employers. In Holden these wage decreases allow for higher profits at a higher level of employment. However, in the efficiency wage model there is one combination of employment and wages that results in maximum profit in an absolute sense - which is of course defined by the Solow condition. Whenever employers have less than full bargaining power, the actual wage/employment combination will deviate from the optimal one and both wages and employment will be at a higher level than the optimal level. Hence, when employers gain bargaining power, both wages and employment will decrease. ${ }^{22}$

22 Note that this result only refers to wage drift, given a certain contract wage. Moreover, it is a partial equilibrium result and does not imply that unemployment will be solved by increasing the 
A second difference with the results of Holden is with respect to wage drift. Assuming that the tariff wage is set such that it is lower than $W^{*}$, employers will set the wage at $W^{*}$ when they have full bargaining power. Hence, wage drift will occur in this model, even when employers have full bargaining power. In the Moene/Holden type of model wage drift is zero in the latter case. A related difference between the Moene/Holden model and the efficiency wage model lies in the motivation of wage drift: In the Moene/Holden model the wage drift occurs independently of $q$, due to exogenous dissatisfaction. In the efficiency wage model, however, the wage drift depends on the difference between the bargained wage and the tariff wage. There is a negative relation between the tariff wage and wage drift because the higher the tariff wage, the higher the minimum acceptable level of profits. ${ }^{23}$ Hence less room for wage drift results.

The efficiency wage model gives a framework for the analysis of efficiency wages in a two-tier wage bargaining system, but one should realize that the way the incentive structure is modelled is important. Two observations are relevant in this respect.

First it is assumed that $\mathrm{e}^{\prime}(\mathrm{q})>\mathrm{e}(\mathrm{q}) / \mathrm{q}$ holds once the tariff wage is determined - this obviously restricts the incentive structure. ${ }^{24}$ As was argued, this assumption implies $W^{*}$ $>\mathrm{q}$. When $\mathrm{q} \geq \mathrm{W}^{*}$, the outcome of the bargaining process will always be a wage rate at $\mathrm{q}$ - and the corresponding employment is found on the demand curve for labour (4.19). In this case bargaining about wage drift makes no sense since wage drift will not occur, whatever the power of the employees is. Therefore it is reasonable to assume that the efficiency wage structure satisfies $e^{\prime}(q)>e(q) / q$ when analysing wage drift..$^{25}$

A second observation can be made by referring to the research of Moene et all. (1992). They also incorporate efficiency wages in a model with central and local wage bargaining. However, contrary to the set-up that is developed in this chapter, where unions aim at maximal wages while ignoring the costs of effort, Moene et all. assume that the utility of the union consists of wages minus the costs of effort for employees. The

bargaining power of the unions.

23 This is also found in empirical analyses. See for instance Driehuis (1975) and Lever (1993) who find a negative rellation between the contract wage and wage drift for the Netherlands for the periods $1953-1972$ and $1972-1983$ respectively.

24. In this respect one also should realize that one of the effort-inducing mechanisms behind efficiency wage may require unemployment in equilibrium.

25 An additional argument is that the wage rate $\mathrm{q}>\mathrm{W}^{*}$ can be sub-optimal for employers since they no longer have the opportunity to increase the wage rate in order to yield higher profits. Moreover, by accepting at the central level a wage rate below $W^{*}$, the employees create the opportunity to end up with both a wage rate above $W^{*}$ and higher employment. Therefore it seems reasonable to assume $q<W^{*}$. 
latter is an increasing function of effort, and effort is subject to bargaining too. Moene et al. show that the optimal level of effort is determined in such a way that marginal revenues of increasing effort for the firm equal marginal costs of increasing effort for the union. Consequently, contrary to the findings in this chapter, they conclude that the equilibrium level of effort is independent of the bargaining power. This result holds irrespective of whether wage bargaining is fully decentralized or whether wages are determined in a two-tier system. Hence, the way the incentive structure is modelled is relevant in these efficiency wage models.

Some problems with the model of Holden remain, which are not solved by the efficiency wage model. The major problem is that the tariff wage $q$ is determined outside the firm - it is determined at the central level. However, it is not clear how the tariff wage is set. Unions must have some kind of utility function with wages and employment as arguments. Moreover, in equilibrium there is a negative relation between the tariff wage and employment - this result is found in both models. Hence, in setting the tariff wage the central union must trade wages against employment.

\subsection{Conclusions}

In this chapter wage drift is discussed. The starting point was an analysis of a widely used type of union-firm bargaining model where wage drift occurs because of the threat of losses in production when employees disagree with the outcome of the central wage bargaining. Efficiency wages have been incorporated in such a model and it can be concluded that the results that follow from this exercise meet the objections that have been made against the Moene/Holden model. In my view, this model is able to explain first the continuing wage drift that can be seen in the Netherlands during at least the period 1973-1983 and second the negative relation between the contract wage and wage drift that has been found in empirical research for the Netherlands. 


\section{APPENDIX 4}

In this appendix I elaborate the Holden model and show how a wage-employment curve can be derived from this model. ${ }^{26}$ I start with the relation between marginal costs, marginal revenues and the wage rate that is implied in this model.

Figure 4A1 Marginal costs, marginal revenue and the wage rate in the Holden model

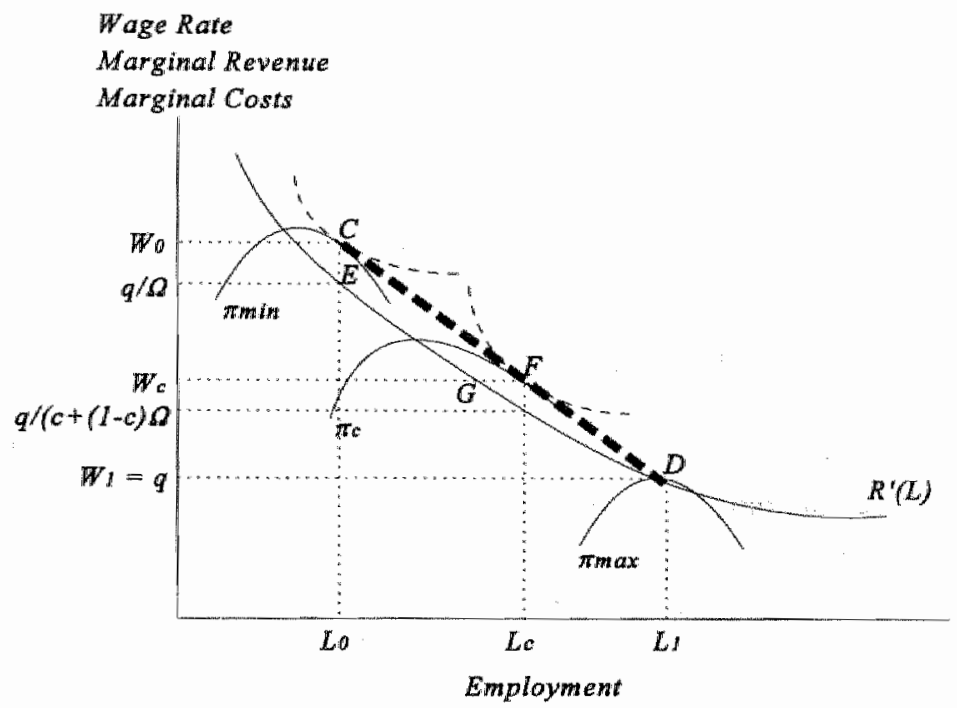

Figure 4A1 shows the relation between marginal costs, marginal revenue and the wage rate in the Holden model. Marginal revenue is represented by the $R^{\prime}(L)$ curve, which is the demand for labour curve. Iso-profit curves, $\pi_{\min }, \pi_{c}$ and $\pi_{\max }$ intersect, when $\mathrm{dW} / \mathrm{dL}$ $=0$, with the $R^{\prime}(L)$ curve. Next three different marginal costs curves, $\mathrm{mc}_{\min },(\mathrm{mc}=\mathrm{q}), \mathrm{mc}_{\mathrm{c}}$ $(\mathrm{mc}=\mathrm{q} /(\mathrm{c}+(1-\mathrm{c}) \Omega))$ and $\mathrm{mc}_{\max }(\mathrm{mc}=\mathrm{q} / \Omega)$ have been drawn, which are independent of employment. Finally I have drawn the wage equation (equation 4.3 in the main text) for $c=0, c=c$ and $c=1$ - the curved broken lines through $C$ and $F$, and the horizontal line

26. Note that Holden (1988) does not analyse his model in this way. Hence this analysis is an extensive interpretation of the model that he presents. 
through $\mathrm{D}$. Note that the iso-profit curve, the marginal cost curve and the wage equation shift when $\mathrm{c}$ is changed. ${ }^{27}$

In the Holden model, employment is determined by maximizing the profit function, given the wage that will be agreed upon. The first order condition for profit maximization results in the equality of marginal costs and marginal revenue. Hence, with the bargaining power equal to $c$, and marginal costs equal to $q /\{c+(1-c) \Omega\}$, the corresponding amount of employment is Lc. Next the wage equation shows the corresponding wage rate, $\mathrm{Wc}$. The final result is that in equilibrium, $m c=m r \leq W$. The solution is off the demand for labour curve - compare point $F$. Would it not be more profitable for the employer to choose a point on the demand curve when $\mathrm{mr}=\mathrm{W} \geq \mathrm{mc}$ - compare point $\mathrm{G}$ ? If this was possible, yes, but in the bargaining set-up of this model a solution on the demand for labour curve is not possible. For, if the employers, starting from point $\mathrm{F}$, decreased the amount of employment to reach point $G$ on the demand for labour curve, the corresponding wage would, however, increase - as can be seen from the wage equation - and again a point off the demand curve would be reached. Hence, solutions on the demand curve are unstable, because the unions can force the employers off their demand curve.

If all combinations of wages and employment that follow from the solution of the game are combined, one finds the curve $\mathrm{CD}$ which is called the wage-employment curve. It can easily be proved that at each point on this curve, the wage equation is tangent to the iso-profit curve. From the wage equation (4.3) one can derive

$$
d W / d L=(1-c)(1-\Omega)\left\{\left(R^{\prime}(L) L-R(L)\right) / L^{2}\right\}
$$

The slope of the iso-profit curve is equal to: $:^{28}$

$$
d W / d L=\left(R^{\prime}(L)-W\right) / L
$$

Substituting equation (4.3) for the wage one finds

$$
d W / d L=R^{\prime}(L) / L-\left\{q / L+((1-c)(1-\Omega) R(L)) / L^{2}\right\}
$$

If equation (A4.1) and (A4.3) are compared, one finds

Of course, they also vary with $\Omega$, but this is not important for my purpose . 


$$
(1-c)(1-\Omega) \leq=\geq 1-\left(q / R^{\prime}(L)\right)
$$

Hence in general the slopes differ. However, from equation (4.5) it is known that in the optimum

$$
R^{\prime}(L)=q^{\prime}(c+(1-c) \Omega)
$$

holds. If one substitutes equation (A4.5) in (A4.4), one finds that in the optimum point the slope of the wage equation is equal to the slope of the iso-profit curve. This expresses the maximization of profits given the wage-employment combination. Hence, the curve $\mathrm{CD}$ is the contract curve. It is the same curve as has been depicted in Figure 4.1 in the main text and it shows all optimal combinations of wages and employment.

Note that this model is neither the efficient bargain, nor the right-to-manage model. It is not an efficient bargain model because there is no bargaining about employment. However, although wages are bargained upon and employers unilaterally determine the level of employment, employers are forced to choose a level of employment that is off the labour demand curve. 


\section{CENTRALIZATION AND DECENTRALIZATION AND DUTCH LABOUR RELATIONS}

After discussing the Doutch wage seting process in chapter 2 and after elaborating on barganihg and wage drith as being two of the charaeteristics of this systen in chapters 3 and 4 , I end this part of the research with a discussion about the nerits and dentents of centrallization and decentrallization in wage bargaining. As has been argued in chapter 2. in the Nethenlands (but also in. other. WesternelEhopean equntries). there is a continuous debate about the extent of decentralization that is desirable in the fabour

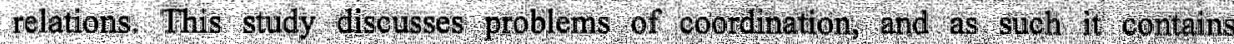
background information for a discussion about (de) entralization of wage bargainug. Does centralization moderate the wages $\mathrm{Boes}$ centralizetion lead to a better econornie perfomance? The answers on these questions depend aning other things: on the way Wage bargains are coord hated. It is concluded that theorelical research both polnts at a positive relation between centralization of wage bargaining and the extent to which wages are modgrated and to strategio beha Wiourt hat can break this positure gelation.

\subsection{Introduction}

The Dutch labour relations can be characterized by a mixture of centralized and decentralized labour relations. Moreover, as in other European countries, there seems to be a continuous struggle for either more centralization or more decentralization. Hence, the question rises whether such a struggle is worthwhile being fought. Is a centralized or decentralized system of wage negotiations to be preferred because of its merits?

In the 1980 s, much theoretical and empirical effort was dedicated to the relation between the structure of wage bargaining and economic performance (Bruno and Sachs (1985), Abraham (1987), Calmfors and Driffill (1988), Freeman (1988), Mulder (1989), Jacobs and Janssen (1990), Soskice, (1990), Calmfors (1993), Cörvers and Van Veen (1995) to mention just a few references).

Some ideas from this chapter have been published before in Albeda and Van Veen (1990); Delsen and Van Veen (1992) and Cörvers and Van Veen (1992; 1995). 
It has been argued that centralization of wage bargaining moderates the wage increases. The core of the argument is that a central organization of unions or a central union is able to internalize all kinds of externalities that occur if separate unions set the wages in various industries.

In this chapter the relation between the wage bargaining process and the development of the wages will be discussed. It starts with the question whether and why central bargaining can be advantageous for the development of wages (5.2). Next, applications in analytical models are discussed (5.3) and finally, attention is paid to the results of empirical research in this field (5.4). Section (5.5) ends with the conclusions.

\subsection{The relation between centralization and decentralization and economic performance}

Problems of stagflation and adjustment policies in the $1970 \mathrm{~s} / 1980$ s have focused much attention to the relation between the institutional framework of the economic activities and economic performance. The wage bargaining structure especially has been the subject of analysis, since the development of wages is a key element in the adjustment process.

Various types of bargaining structures occur in Western countries. In the United States and the United Kingdom, bargaining at the level of the firm dominates. In the Scandinavian countries, Germany, the Netherlands and Austria wages are set at the level of the industry and there is some kind of coordination in the industry wage demand. This is sometimes called corporatism. In France wage bargaining is only at the level of the industry."

In this light the question whether centralized or decentralized wage bargaining is to be preferred is of interest. When the research on this topic is summarized, one can distinguish between two types of analyses. First, there is a theoretical line of research, focusing on the conceptual framework of coordination and the possible applications. Second, there has been a lot of empirical research concerning the relation between corporatism and economic performance. Both types of research will be discussed. Note, however, that I focus on the relation between the bargaining structure and the development of wages (which is of course only part of economic performance). The reason is twofold. First, in the research that $I$ discuss the focus is on wage

1 Of course, this is a much too unshaded picture of such a complicated phenomenon as labour relations. Some more details and the way corporatism can be measured is provided in Bruno and Sachs (1985, ch. 11) and in Cörvers and Van Veen (1995). 
developments and second, in a small open economy as the Dutch, the development of wages is seen as a key variable for economic performance.

\subsubsection{Theoretical considerations}

\subsubsection{The start: the Prisoner's Dilemma Game}

The conceptual framework underlying the merits of centralization is often sketched with the help of game theoretical concepts. It starts with the notion of the prisoner's dilemma and I follow Van den Doel (1978). Assume that an economy is characterized by high wages and low employment and suppose that wage bargaining takes place between unions and employers. There are $n$ unions $(n>1)$. Assume further that each union and each employer is so small that it can exercise only a negligible influence on the aggregate wages and employment. Finally, it is assumed that a situation of lower wages and higher employment is preferred to high wages and low employment but to reach this situation a moderation of the wages is needed. Given these assumptions, the prisoner's dilemma states that a bias exists towards too high wages and too low employment and the most preferred outcome will not be reached. Table 5.1 can be used to illustrate the game. If unions can only decide about the wages, each union has two strategies and the four outcomes are listed in Table 5.1. A distinction is made between sector $i$ and $j$ with $j=1 . . n$ and $j \neq i$; sector $i$ contains one union and sector $j$ covers all other sectors and hence contains a number of unions. With $(j, j)$ the value of the game for player $\mathrm{j}, \mathrm{i}$ respectively is denoted. The payoff range is $\{-4,+3\}$. In the determination of the payoff the following assumptions are used. ${ }^{2}$ If real wages hardly change and employment is low and prices are high, the value for both players is set at 1. If real wages hardly change, but employment is high and prices are low, the value for both players is set at 2 . Finally, if an outcome for a party results in a relative decrease in real wages, the value is set $<1$, while the other party reaches a value $>1$ : these losses are not symmetric because the players differ in size. ${ }^{3}$ Finally, a one-shot garne is assumed.

2 In fact, a preference structure is defined in this Table. The value of the combinations is not derived from a utility function.

3 Note that these values do not depend on the amount of employment. 
Table $5.1 \quad$ The prisoner's dilemma in case of many unions

\begin{tabular}{|l|l|l|}
\hline union $\mathrm{i}$ can $\rightarrow$ & moderate & not moderate \\
\hline $\begin{array}{l}\text { the other unions }(\mathfrak{j}) \\
\text { can } \downarrow\end{array}$ & & \\
\hline moderate & $(2,2)$ & $(-2,3)$ \\
\hline not moderate & $(2.5,-4)$ & $(1,1)$ \\
\hline
\end{tabular}

If parties aim at the minimalization of the potential loss, it will be clear that in this game the dominant strategy for both parties is given by setting high wages (=not moderate). This means that "not moderate" is for a party the best strategy, whatever strategy the other party follows. Hence, this game results in the non-cooperative equilibrium and the payoff then is $(1,1)$. This is a Nash-equilibrium because for each party it is the best possible strategy, i.e the best possible reply to a possible strategy of the other party. In this equilibrium the economy will stick in high prices and low employment, resulting in a payoff of $(1,1)$, although both parties prefer a situation with lower wages and higher employment which gives a payoff of $(2,2)$. Consequently, in this game a Pareto-improvement is possible. The core of the prisoner's dilemma game is that the individual optimum (no moderation of wages) does not coincide with the social optimum (moderation of wages). Single unions are captured in a Nashequilibrium instead of a Pareto-efficient equilibrium. And it will be immediately clear why the Pareto-efficient equilibrium is not automatically reached: suppose that wage moderation is agreed between the unions and that union $\mathrm{i}$ keeps the promise. Then the other unions gain if they cheat and do not moderate their wage demands. Hence, the unions must be forced to follow a policy of wage moderation and centralization of wage bargaining is then one possibility to enforce cooperation and to reap the Pareto gains (Van den Doel et. al (1976)). Thus, if parties want to reach the cooperative solution (the Pareto-optimal outcome) in this game, they have to solve problems of enforcement and credibility. These problems do not occur when they choose the Nash equilibrium. ${ }^{4}$

4 Note that I have described a one-shot game. Axelrod (1984) has shown that in a similar game that is played an infinite number of times, cooperation is the best (i.e. profit maximizing) strategy, if strategies are based on the TIT-FOR-TAT approach. 


\subsubsection{The continuation: spillover effects}

The idea that cooperation might be necessary to reach a Pareto-efficient solution has been subject of much research in the last decade. Not only one-shot games (games that are played once), but also repeated games (games that are played a number of times) draw much attention. ${ }^{5}$ Further, in this research attention has shifted from the prisoner's dilemma game to problems of coordination or coordination failures. In the latter type of games, there is no dominant strategy, but they are characterized by the existence of multiple equilibria. Results of this research has been applied to international economic relations (Frankel and Rockett (1988)), to macroeconomics (Diamond (1988), Cooper and John (1988)) and to theories regarding wage determination (Abraham (1987), Mulder (1989), Jacobs and Janssen (1990)). I follow the concepts developed by Cooper and John to continue the discussion about the merits of centralization.

Cooper and John have introduced the concepts of strategic complementarity and spillover effects to illustrate the problem of coordination failures in an economy. Suppose, there are two parties, each having the choice between two strategies. Each strategy has a certain payoff. Spillover effects exist if the payoff of the prevailing strategy to player 1 changes because of a change in the strategy of player 2 . The change can be positive or negative, leading to positive and negative spillover effects, respectively. A strategic complementarity occurs if the marginal payoff of each possible strategy of player 1 rises because of a change in the strategy of player 2 . Hence, player 1 can have an incentive to alter his choice of the optimal strategy if player 2 changes his strategy. Therefore, the implication of strategic complementarity is that the strategies of both players are interdependent. Note that if the relation between the marginal payoff for player 1 and the change in strategy of player 2 is negative, there is strategic substitutability. To summarize, "The former [spillovers] refers to the interactions between agents at the level of payoffs, while the latter [strategic complementarities] refers to interactions at the level of strategies" (Cooper and John, p.4).

Table 5.2 can be used to illustrate these concepts for the problem of wage moderation. This table models a coordination game and closely resembles Table 5.1. The difference is, however, that in a coordination game there is no dominant strategy (Van Damme (1990)). I slightly change the set-up and assume now that there are only two unions, $i$ and $j$, that bargain with a confederation of employers' organizations. During the bargain unions must react to a proposal of the employers. The unions must

5 Axelrod (1984) for example, demonstrates in what respects repeated games differ from oneshot games. In the game that he has developed, no cooperation is the best solution in the one-shot game, while cooperation is the best solution in the repated game. By best I. mean "gives the highest result". 
simultaneously decide which strategy they will follow and can not discuss their strategies beforehand. As before I assume that unions can only decide about the wages and the four outcomes are listed in Table 5.2. With $(j, i)$ the value of the game for player $\mathrm{j}, \mathrm{i}$ respectively is denoted.

Table 5.2 A coordination game

\begin{tabular}{||l|l|l|}
\hline union i can & moderate & not moderate \\
\hline union (j) can $\downarrow$ & & \\
\hline moderate & $(2,2)$ & $(-0.5,1.5)$ \\
\hline not moderate & $(1.5,-0.5)$ & $(1,1)$ \\
\hline
\end{tabular}

Both unions can decide to moderate or not to moderate and two equilibria exist in this type of game; either both unions moderate or both unions do not moderate their wage demands. Both are Nash-equilibria: if union i moderates (not moderates) the best strategy for union $\mathrm{j}$ is to moderate (not moderate) as well. If one union does moderate while the other does not, the relative position of the moderating union deteriorates while the relative position of the non moderating union improves. Hence the moderating union will revise its strategy in this case. It is obvious that moderation by both unions gives the highest payoff. But face the position of an individual union. For this union a policy of moderation involves a risk because it only improves its payoff if the other union moderates its wage demand as well. The existence of multiple equilibria gives rise to a problem: to quote Van Damme: "game theorists are divided about the question which equilibrium will be reached when the game is played by rational players" (p. 1039, translation by the author). But for our purpose it is important to notice that also in this type of games cooperation can improve the payoff. $^{6}$

In this game spillover effects exist, because if union $\mathrm{j}$ changes its strategy, while union $i$ does not, the value of the strategy for union $i$ changes. The same is true if union $i$ changes its strategy, while the other union does not. As an example, suppose that union $\mathrm{j}$ which followed a policy of moderation decides to leave this policy. Then

6 As Van der Lecq (1996) shows, the coordination game that I have sketched in Table 5.2 is only one out of several possibilities to model a coordination game. Further, one must note that although two Nash-equilibria exist, they are not equal in every sense, because the Pareto- efficient Nash equilibrium involves a higher risk. 
the outcome for union i will decrease from 2 to -0.5 . Note that both positive and negative spillover effects are present. In this game there is also strategic complementarity because if union $j$ changes its strategy, union $i$ can gain by changing its strategy too. The most obvious example is a change from non-moderation to moderation of wage demands by union $\mathrm{j}$. The gain, already reached via the spillower effect, can be enhanced if union i decides to moderate its wage demand as well.

What are the effects of the existence of externalities in this wage setting model? First, note that if positive spillover effects exist, a Pareto improvement is possible. Therefore, the existence of spillover effects generates inefficiencies. Second, because of the existence of the strategic externality multiple equilibria can occur. ${ }^{7}$ Hence, the conclusion must be that if externalities are present, coordination can improve the efficiency of the outcome.

Thus both the prisoner's dilemma game and the coordination problem can be used to illustrate why coordination of wage setting can result in lower wages. However, if coordination of wage setting is reached via central wage bargaining, one must note here that central bargaining can fall prey to the accommodation dilemma. This occurs when encompassing unions take advantage of the goals of government policy (Abraham (1989), Gylfason and Lindbeck (1986)). Suppose that the government aims at reaching an employment target, while the encompassing union sets the wages. Because the union knows that if wages are too high and hence employment too low, the government will adopt expansionary fiscal or monetary policy, the union has an incentive to increase the wage demands. This reaction of the union has to be taken into account by the government in designing optimal economic policy.

One might wonder whether this accommodation dilemma actually is relevant in central bargaining. The dilemma can be relevant in a one-shot game, but I doubt whether it is important in a repeated game. If it is assumed that both parties use the same economic model and behave in a rational way, it need not be advantageous to play this dynamic game at all. For, the central union then knows that the government cannot correct continuously too high wage demands. This argument is in line with Olson (1971) and Axelrod (1984) who both stress the idea that cooperation is easily reached in small groups exactly because they are aware of these dynamics in the game.

One can summarize the findings as follows. If the wage rate that is realized by a union depends on the wage rate set by other unions, an externality exists. Then coordination of wage setting can lead to a Pareto improvement for all parties. It must

7 I do not give a formal proof of these statements. For such a proof I refer to Cooper and John (1988). Note that in their proposition 1, they state that strategic complementarity is a necessary condition for the existence of multiple equilibria. The sufficient condition relates to the slope of the reaction function. 
be clear, however, that the nature of the interdependencies is an important element in the analysis. Until now, these relations have not been discussed, but in the next section, where some applications are discussed, these connections will explicitly dealt with.

\subsection{Coordination between unions in analytical models of wage setting: some applications}

This section elaborates on two contributions in the literature concerning the topic of coordination and wage setting. These contributions are chosen because they are closely related to the theory expounded in the previous sections (Jacobs and Janssen (1990)) and they discuss an interesting externality: the relation between the tax rate and the bargaining structure (Mulder (1989)).

Jacobs and Janssen (1990) discuss the question whether coordination between unions leads to lower wages and higher employment, compared to a situation where unions do not cooperate. In analysing this question, they use a two-sector general equilibrium model with imperfect competition where prices clear the markets. The model was originally developed by Cooper. Unions set the wages according to the monopoly model. The framework consists of three types of households: firms, households and the foreign country. Each agent maximizes a utility function, given the usual budget constraint. Let us call the two sectors, $i$ and $j$. From the set-up of the model it follows that the production in sector $i$ depends on the wages in both sectors as well as on the production in sector $j$. The relation between the levels of production in both sectors is positive, implying strategic complementarity. The mechanism behind this complementarity is that a rise in production in sector $\mathrm{i}$ implies a rise in income in sector i. This increase in income is (by assumption) spent in the other sector, increasing production in that sector. ${ }^{8} \mathrm{Next}$, there is a one-to-one relationship between production and employment.

The consequences of a change in the wage in sector $i$ are as follows. ${ }^{9}$ Assume that wages in sector $\mathrm{i}$ increase (note that by assumption households and owners of firms do not consume goods that are produced in their own sector and there is no labour mobility between sectors). First, production and thus employment in sector i

8 This is a first order effect. Of course, when production in sector $\mathrm{j}$ increases because of an increase in income in sector $i$, this will in its turn have a positive impact on production in sector i. These second-order effects can be summarized in a multiplier as is also shown by Jacobs and Janssen.

9ote that the model is symmetric, i.e. $i$ and $\mathrm{j}$ are interchangeable. 
decrease. ${ }^{10}$ Further, profits decrease in sector i. Dependent on the marginal consumption out of profits and out of wages, production and employment in sector $j$ either increase or decrease. Hence, an increase in wages in one sector can exert positive or negative externalities.

Unions maximize a utility function consisting of real wages and employment. As employment depends on the wages set in both sectors, the utility maximizing wage level depends on the wages that are reached in the other sector. Prices are defined as a mark-up over wages and the general price level is a geometric average of the prices of the various sectors. Thus, a rise in nominal wages in sector $\mathrm{i}$ raises the general price level and therefore the nominal wage in the other sector. This effect diminishes the possible positive strategic externality effect of a wage increase in sector $i$ on employment in the other sector.

The Nash equilibrium is reached if unions do not cooperate. If there are no externalities, the Nash equilibrium is the optimal solution. If there are negative externalities, then an increase in the wage rate will decrease production in both sectors. Subsequently, prices in both sectors will rise. The reverse is true for a decrease in the wage rate. In case of positive externalities, an increase in wages boost production in the other sector (see footnote 8).

If unions cooperate, a common utility function has to be maximized. Jacobs and Janssen do not give a solution for this situation. In a qualitative analysis they argue that in case of negative externalities the cooperative wage lies below the Nash equilibrium wage, leading to lower prices and higher production. In case of positive externalities coordination leads to higher wages (than the Nash equilibrium). Note, however, that in reaching the latter result, the fallacy of composition plays an important role: one union may succeed in increasing employment by decreasing wages. All unions cannot increase employment by lowering wages, because of the reduction in demand that will follow a nationwide decrease in wages. Recall that in case of positieve externalities, the relation between a wage increase in sector $i$ and employment in sector $\mathrm{j}$ is positive, despite the increase in the general price level.

From Jacobs and Janssen it can be concluded that coordination can improve the efficiency of the economy. In their analysis this depends on the existence of externalities, the existence and sign being dependent on the values of the marginal

10 The reason why production decreases is not made clear. According to Jacobs and Janssen, "The evaluation of $d y i^{*} / \mathrm{dW}$ is slightly more complicated. In appendix $\mathrm{A}$ it is shown that $\mathrm{dyi} / \mathrm{dWi}$ cannot be positive" (yi* is the production in sector i). To be clear, their analysis is based on comparative statics. Hence they basically mean that, in the end, when all adjustment processes have finished, production in sector i cannot be higher than at the start of the process. 
propensity to consume out of wages and out of profits. Note that the same conclusions are reached by Abraham (1987) who has developed a similar model.

Mulder (1989) aims to give a theoretical explanation for the empirical finding of Bruno and Sachs that there is a relation between the extent to which wage negotiations are centralized and wage moderation. He has developed a model where unions, employers and the government decide upon wages (using the LDEM model) and taxes. Unions do care about real disposable wages and hence their utility is influenced by the tax rate. The core of Mulder's argument is that the nature of the tax rate depends on the extent to which wage bargaining is centralized. When negotiations are fully decentralized (there exist $\mathrm{n}$ small unions, each bargaining about wages with an employer), the tax rate is exogenous for the parties. In the other extreme, the tax rate is endogenous. Assume an increase in wages. This results in lower employment and higher expenditures on unemployment benefits. Given the government budget constraint, this implies that a wage increase leads to a tax increase. ${ }^{11}$ Mulder argues that this positive relation between the change in wages and the change in the tax rates does not play a role in the decentralized wage negotiations since at this level the tax rate is assumed to be exogenous. Hence, there is a negative spillover effect because if the (n-1) other unions increase their wage demands, the tax rate will rise and the net disposable wage for the nth union will decrease. In centralized wage negotiations, however, the relation between a change in wages and a change in the tax rate is explicit and clear for the parties. Hence, they incorporate this relation into their negotiations. Consequently, the threatening rise in the tax rate moderates the wage demands. The analysis of Mulder is interesting because he basically argues that the trade-off between wages and taxes differs with the level of bargaining. A similar idea is expanded in chapter 9 where the influence of taxes in a three-tier wage bargaining model is discussed.

From Mulder's analysis it follows that, in comparison with a situation of decentralized bargaining, gross wages are lower and employment is higher under centralized bargaining. Note that the condition that an increase in gross wages is followed by a rise in the tax rate is important in reaching this conclusion. ${ }^{12}$

11 In fact, three mechanisms occur following an increase in wages. First, government revenues rise. Second, total unemployment benefits rise and third, wages of civil servants (that are related to the average wage level) increase. Only the first mechanism creates the possibility for a decrease in the tax rate, while the second and third effect imply an increase in the tax rate. Throughout the analysis it is assumed that the impulses for an increase in the tax rate dominate.

12 Although the gross wage is lower in the case of centralized wage bargaining, this does not necessarily mean that net wages are also lower. The finall result depends on the specification of the various functional relations. However, this implies that it is not possible to determine whether there is 


\subsection{The relation between centralization of wage bargaining and economic performance: empirical evidence}

In their extensive study concerning the economics of worldwide stagflation, Bruno and Sachs (1985) noticed that the growth-inflation trade-off differs significantly between countries. Moreover, they note that

"From our earlier work and our results later in this chapter, it appears that real wage moderation is a key to achieving low inflation and low unemployment after a supply shock" (p. 217).

Bruno and Sachs argue that two characteristics of the labour market are favourable for real wage moderation. First, centralization of wage bargaining (called corporatism by Bruno and Sachs) and second long contract periods and nominal wage rigidity. ${ }^{13}$ Corporatism is favourable, because it is an utterance of underlying consensus. By consensus they mean consensus about the distribution of the national product between wages and profits or consensus about the idea that wage moderation can be exchanged for expansionary fiscal policy. Bruno and Sachs find indeed a significant influence of corporatism on inflation, the wage gap and the change in the misery index (the change in the misery index equals the rate of inflation plus the slowdown in economic growth).

The research of Bruno and Sachs belongs to a research programme concerning the relation between corporatism and economic performance. The relation is generally investigated by way of (multiple) regression analysis. About 18 OECD countries have been subjects of such research. Since corporatism is often defined by the degree of centralization in wage bargaining, this research typically fits into the subject of this chapter.

strategic complementarity or strategic substitutability in Mulder's analysis.

13 This argument of nominal wage rigidity has, of course, long ago been used by Keynes as a possibility of decreasing wages (Keynes, 1936, ch. 19). In my view, however, one has to assume some kind of money illusion for such a policy to work. Referring to the famous monetarist standpoint: One cannot fool all the people all of the time. In wage bargaining: if there is no money illusion, one cannot keep trying to decrease real wages by using nominal wage rigidities and inflate the economy. If one tries, contracts will be renegotiated or the contract length will shorten or agents will anticipate this strategy, resulting in increasing wages. Of course, in modern language the old monetarist adage is now: credible rules are to be preferred above discretionary policies (Barro and Gordon, 1983). 
There are two major points of discussion concerning empirical research on the impact of corporatism on economic performance. First, there are various ways of measuring the phenomenon of corporatism. Second, there are several indicators of economic performance which can be regressed on corporatism.

\section{How to measure corporatism?}

The way corporatism is measured in the empirical research has been inspired by Crouch (1985): e.g. Bruno and Sachs (1985), McCallum (1986) and Freeman (1988). Crouch (1985) classifies 18 OECD countries into neocorporatist and liberal countries. (Neo)corporatism in Crouch's sense refers to the degree of coordination at the bargaining table, i.e. the extent to which labour unions and employer organizations are coordinated. This coordination can take several forms (Soskice, (1990), Calmfors (1993), OECD, (1994), part II). It is not only tripartite arrangements between unions, employers and government that are an expression of coordination. Pattern bargaining/wage leadership, much coordination between unions that separately negotiate about wages are some of the cases where a high degree of coordination goes without centralization of wage bargaining. ${ }^{14}$ However, especially this last form of coordination is very difficult to recognize and therefore some researchers think Switzerland and Japan are corporatist because of their high degree of coordination, while others argue that they are not because of their high degree of decentralized wage bargaining. One certainly needs a careful study of the wage bargaining process for these kind of classifications. Both Soskice (1990) and Cörvers and Van Veen (1995) find that the classification of Switzerland is important for their results.

In a regression analysis, a dummy or an index is used to indicate the strength of the corporatist elements in a country. Crouch's classification is used by Freeman (1988) for the construction of his dummy variable. However, most researchers prefer the use of an index of corporatism to construct a rank ordering of industrialized countries. The indices of Bruno and Sachs (1985) and McCallum (1983, 1986) increase with the centralization of employers" associations and labour unions, with the decline of shop-floor union power, and with the presence of works councils. The index of Cameron (1984) measures corporatism by highlighting only the organizational power of employees, i.e. the membership rates and the degree of centralization of unions. Schmidt's index (1982) takes account of a number of variables, including the consensus between the government and employers' and employees' representatives, and the strike activity of employees. Note that Cörvers and Van Veen (1995) have

14 See allso Den Broeder (1996) who discusses overt coordination (ex-ante coordination of wage claims) and covert coordination (ex-post coordination of wages through wage leadership). 
discussed the way corporatism is measured. They investigated whether the various classifications of countries into corporatist and non-corporatist are robust in the sense that these classifications will also hold when other criteria for corporatism are incorporated as a measure. For example, one can argue that apart from the level of wage bargaining, expenditures on labour market programmes or average unemployment benefits or government expenditures ( $\%$ of GDP) can be used to classify countries as corporatist or non-corporatist. From their research it follows that corporatist and non-corporatist countries (according to the classifications that are mentioned before) differ in more aspects than centralization of wage bargaining alone.

\section{What is economic performance?}

Several indicators of economic performance can be regressed on corporatism. Table 5.3 shows the results of empirical research concerning the relation between corporatism and economic performance, where the last term is measured by real wages, unemployment, inflation and strike activity. Note that low unemployment, low inflation and a low strike activity exert a positive influence on economic activity. This is not necessarily true for low real wages. However, the research that is discussed stresses the need for low real wages because this would help to restore necessary adjustments in the economy in the 1980s and the 1990s. The oil crises of the 1970s and the government policies that followed, cried for these adjustments.

In Table 5.3, a coefficient of regression indicates that there are other independent variables included in the regression analysis. If there is a coefficient of correlation, the corporatism variable is taken as the only independent variable. The overall picture supports the presumption that the presence of corporatist elements has a favourable effect on wage control, unemployment, inflation, and strike activity. All coefficients presented show the expected sign and most of them are significant. The coefficient of -5.41 in Freeman (1988) is close to sïgnificance. ${ }^{15}$

15 Since it might not immediately be clear what the results imply, I explain some of them. Bruno and Sachs use an index and their results show the change in real wage growth and inflation (in percentage points) caused by a unit rise in the corporatism index. The dummy of Freeman has a value of 1 in case of a corporatist country and 0 else. His results denote the influence of corporatism on the change in reall wages and on level of employment and unemployment. In McCallum (1983), b(P,K) means that an increase on the index by 1 point caused a $0.86 \%$ decrease in average inflation over de the period 1971/2-1979. Note that all results are based on cross-section analyses for a number of: OECD countries. 
Table 5.3 Results of empirical research on the relationship between corporatism and economic performance

ressearchers perilod measure of

corporatism result

index

$$
\begin{aligned}
& b(w, K)=-1.11^{*} \\
& r(w, K)=-0.64^{*} \\
& b(w, K)=-4.28^{*} \\
& r(w, K)=-0.52^{*}
\end{aligned}
$$

Corporatism (K) and real wages (w)
$\begin{array}{llll}\text { Bruno and Sachs }(1985) & 1973-79 & \text { index } & b(w, K)=-1.11^{*} \\ & & & r(w, K)=-0.64^{*} \\ \text { Freeman }(1988) & 1979-85 & \text { dummy } & b(w, K)=-4.28^{*} \\ \text { Cameron }(1984) & 1965-82 & \text { index } & r(w, K)=-0.52^{*}\end{array}$

Corporatism and unemployment (U), employment (E)

Schmidt (1982)

Schmidt (1982)

Cameron (1984)

Freeman (1988)

Freeman (1988)
1960-73

1974-78

$1965-82$

1984

1984 index

index

index

dummy

dummy

$$
\begin{aligned}
& r(U, K)=-0.53^{*} \\
& r(U, K)=-0.67^{*} \\
& r(U, K)=-0.40^{*} \\
& b(U, K)=-5.41 \\
& b(E, K)=5.99^{*}
\end{aligned}
$$

\section{Corporatism and inflation (P)}

Bruno and Sachs (1985)

1973-79

1968-73

McCallum (1986)

$1971-79$

McCallum (1983)

$1965-80$

index

$\mathrm{b}(\mathrm{P}, \mathrm{K})=-1.54 *$

index

$\mathrm{r}(\mathrm{P}, \mathrm{K})=-0.1$

index

$\mathrm{b}(\mathrm{P}, \mathrm{K})=-0.86^{*}$

index

$r(\mathrm{P}, \mathbb{K})=-0.18$

Corporatism and strike activity (S)

Bruno and Sachs (1985) 1965-80

McCallum (1983)

1950-69

McCallum (1986)

$1950-78$

Cameron (1984)

1965-82 index

index

index

index

$$
\begin{aligned}
& r(S, K)=-0.50^{*} \\
& r(S, K)=-0.76^{*} \\
& r(S, K)=-0.68^{*} \\
& r(S, K)=-0.47^{*}
\end{aligned}
$$

Nores: $\mathrm{b}(\mathrm{y}, \mathrm{x})$ is the regression coefficient of $\mathrm{y}$ on $\mathrm{x}$, whereas $\mathrm{r}(\mathrm{y}, \mathrm{x})$ represents the correlation coefficient between $y$ and $x$. An asterisk indicates a significant coefficient at the $5 \%$ level.

According to the results presented in Table 5.3, the relation between corporatism and economic performance is positive. Calmfors and Driffill (1988), however, have questioned whether this relation is monotonicly positive or not. This means that they doubt whether, starting from a decentralized level, increasing corporatism will continuously improve economic performance. They conclude that 


\section{"both heavy centralization and far-reaching decentralization are conducive to real wage restraint, whereas intermediate degrees of centralization are harmful. This suggests a hump-shaped relation between centralization and real wages (unemployment)}

Thus, both decentralized and centralized wage setting gives the best results, while wage setting in-between (e.g. at the level of an industry) provides the worst results. According to Calmfors and Driffill, two mechanisms are responsible for this result. First, an increase in wages in one firm will, if subsequently prices rise, shift demand away from this firm to another firm. Especially, if bargaining is at the level of the firm, an increase in wages can be harmful for the specific firm. Hence, resistance of single firms against wage increases is high if these increases are not the same for all firms within the industry. If bargaining is at the level of the industry, the resistance of the single firms will diminish because every firm in the industry faces the same wage increase. Therefore, the shift in demand to the individual firm will be smaller, especially if the elasticity of substitution between industries is smaller than within industries. Hence, centralization from the firm to the industry level is likely to raise wages. This argument is summarized by Calmfors and Driffill as the market power effect noting that more centralization increases market power and creates a bias for rising wages.

Second, an increase in wages will foster a rise in prices. This is called the price effect. If wages rise in one industry, the effects of this increase on the general price level is small, and real wages may rise. If wage increases are nationwide, however, as can be the case when one encompassing union exists, the increases will only have nominal effects. The expected increase in prices will tend to keep real wages unchanged. The ultimate effect is a worsening in the competitiveness of the country. There is, therefore, no incentive for such a central union to increase the wages far beyond the possibilities. ${ }^{16}$ Hence, centralization from the industry to the central level is likely to slow down the wage demands.

Calmfors and Driffill do not estimate their model but simulate it, both for the monopoly model and for the case of an efficient bargain. It follows that the market power effect is very sensitive to the value of the elasticity of substitution: "When the elasticities of substitution at lower levels of aggregation are progressively raised (..),

16 Usually, the possibilities for a wage increase are determined by the sum of the change in labour productivity plus consumer prices. If the increase in nominal wages does not exceed this sum, the relation between wages and profits (measured at macro level) remains the same. Unit wage costs rise, however, if the increase in wages exceeds the increase in labour productivity. See also footnote? in chapter 2. 
the real wages set by small industry unions progressively fall, while those set by larger unions remain unchanged" (Calmfors and Driffill, p. 35). Hence the hump-shape itself depends very much on the value of the elasticity of substitution between goods produced by different sectors.

The main conclusion of Calmfors and Driffill, the hump-shape relation, is confirmed in a paper by Freeman (1988). He has estimated the influence of corporatism on changes in employment, unemployment and hourly compensation. The relation between corporatism and employment/unemployment proves to be significant and of the expected sign, implying the higher the degree of corporatism, the better the employment record. Moreover, the relation is non-linear.

Jackman et al. (1990) use the index for corporatism as developed by Calmfors and Driffill in their estimates of the policy influences on the unemployment-vacancy curve in the period 1971-88. ${ }^{17}$ Their results show that corporatism has significantly lowered the unemployment rate. Jackman et al., however, point to the fact that the interpretation of these results causes some difficulties. They argue that it is also possible that more consensus prevails in corporatist countries regarding for example labour market policies and that centralization of wage policy need not be the cause of moderate wage developments.

Much research on the relation between corporatism and economic performance uses data from the 1970s and the 1980s. However, important changes took place at the end of the eighties and the early nineties, not least in corporatist countries. This point is recognized by the OECD (1994) that argues that unemployment rates increased in the Scandinavian countries from 1990 to early 1994 . Moreover, when analysing the private sector only, they conclude that "the expansion of private sector jobs over the period 1973-89 was as sluggish in Sweden, Norway, Finland and Austria as in the EC countries" (p. 20). Research results that cover a more recent period are found in Scarpetta and Jackman et al. Scarpetta's (1996) research covers the period 1983-1993 and incorporates $17 \mathrm{OECD}$ countries. He concludes that both highly centralized and decentralized bargaining systems have lower wage increases, higher employment and lower unemployment levels. The worst possible organization of wage bargaining systems is the industry-level system (p. 71/72). Jackman et al. (1996) link coordination to union coverage. When union coverage is high, there is an upward pressure on wages, but sufficient coordination can offset these negative employment effects. Their research covers the period 1983-1994 and includes 20 OECD countries. They find a

17 In the literature, corporatism is not unambiguously defined. Calmfors and Driffill, however, have stressed the centralization in wage bargaining in corporatist countries as the core of corporatism. Their index, therefore, leans heavily on this idea. 
significant effect of union and employers' coordination on short-term and on total unemployment (higher coordination causes lower unemployment). Moreover, coordination has a significant positive effect on the impact of unemployment on wages as measured by the respective elasticity.

The Calmfors-Driffill hypothesis is based on a rather simple model for a closed economy. Hence it has been criticized on these grounds. This criticism is discussed in a survey concerning centralization of wage bargaining and macroeconomic performance by Calmfors (1993). Although he finds that a non-linear relationship between corporatism and economic performance is sometimes found in empirical research, he concludes that "the link between centralization and macroeconomic performance appear so complex that a scientific consensus on how best to organize wage bargaining seems unlikely to develop" (p. 184). Elaborating on this point, I want to point out that there are some important shortcomings in this kind of empirical research. First, the empirical research listed here extends over a long time. In most of the research the strength of corporatist elements is assumed to be stable (the index is kept fixed), although labour relations are constantly developing. The centrallization/decentralization debate regarding wage bargaining has been going on for a long time in corporatist countries such as the Netherlands and the Scandinavian countries (Delsen and Van Veen, 1992). This has an influence on the labour relations. Second, there are many institutional and economic differences between the OECD countries. It is not clear to what extent corporatist elements account for the diverging economic performances of countries which are subject to various macroeconomic policies. Third, although corporatism is a multi-dimensional variable, it is generally being measured only along one dimension, e.g. the centralization of wage bargaining. However, co-determination in economic policy is also an important idea behind corporatism. Hence, one might expect that government policy differs between corporatist and non-corporatist countries and that his difference in policy accounts for the results that are reported. In Cörvers and Van Veen (1995) it is shown that government policies indeed differ between corporatist and non-corporatist countries.

I think that Layard et al. (1996) provide the most appropriate conclusion: "The truth is that coordination is a very subtle affair. But the more there is, it appears, the better. Equally the task of achieving it appears to have become more difficult, possibly reflecting the greater exposure to international competition in both product and factor markets in recent years". Note that their implicit monotonicly positive relation is not supported by other research. But, this might be due to the fact that they assume high union coverage.

To summarize, empirical evidence supports the view that there is a positive relation between centralization of wage bargaining and wage moderation. This does not 
imply, however, that decentralization in wage bargaining shows worse results, since a hump-shape relation may very well exist.

\subsection{Conclusions}

In the Netherlands both centralized and decentralized bargaining occurs. The aim of bargaining at the centrall level is to reach an agreement about a so-called social contract. Real negotiations take place at the industry level. However, social contracts have seldom been concluded (see chapter 2). The results of centralized bargaining are broad guidelines and principles regarding the preferred development of wages, employment and other elements of labour conditions. The status of these guidelines is not always clear because negotiators at the level of the industry are free to deviate from these rules. It is important to note that the principles, as published by the confederations of both employers and employees, do influence the negotiations in the industries, although the strength of the influence may vary over the years (see also chapter 2, section 2.3.3). Albeda and Dercksen (1994) conclude:

"One can, despite the unmistakable trend of decentralization in the labour relations, not argue that central deliberation in the 1980s has stopped. There has, however, been a change in character in relation with the 1960s and 1970s. In those years the aim was to reach concrete agreements about wages, but in the last decade this starting-point has been left. The central agreements only give the direction for the development of wages and solutions for unemployment". (Ch. 3, translation by the author)

Next, the question whether there are arguments in favour of centralized or decentralized bargaining is discussed. I used the prisoner's dilemma game and the coordination game to illustrate the problem and the mechanisms at work. One can conclude that since encompassing unions can internalize externalities that may occur in decentralized negotiations, central bargaining can have a positive effect on wage moderation. However, one needs to realize that the encompassing organizations, in order to reach this positive result, have to solve a difficult moral hazard problem and enforcement problem. Especially in the Netherlands, where there is no real bargaining at the central level but where encompassing organizations try to reach a social contract, the details of which must be agreed upon at the industry level, they have to get the industry unions on the right track. Besides, the government may have to solve the accommodation dilemma. 
It is further concluded that in empirical research, a positive relation between corporatism (measured by the extent of central bargaining) and economic performance, measured by low unemployment, low inflation and low strike activity, has been found. ${ }^{18}$

Finally, note that the Dutch system is difficultly captured on a scale ranging from decentralization to centralization. The difficulty is that in the Netherlands a system of both centralized and decentralized negotiations exists and that the relation between these negotiations is rather unclear. I return to this topic in chapter 9, where a three-tier wage bargaining system is analysed.

This chapter ends the first part of this study. The starting point was a description of wage formation in the Netherlands. Two striking features, viz. wage bargaining and wage drift were elaborated and modern developments in wage bargaining theory and wage drift were analysed. Thereafter it was investigated whether the discussion about the level of wage bargaining makes any sense and I conclude that it does.

What is the relevance of the analysis in part I for an analysis of the Dutch process of wage negotiation? I make 3 remarks. First, concerning chapters 2 and 3, I conclude that in a typical Dutch collective labour agreement, there are no explicit appointments about employment. Further, wages are not unilaterally set, but bargained between industry unions and employers' organizations. Therefore, the RTM model seems most adequate to analyse this process. Second, concerning chapters 2 and 4 , I note that in the Netherlands there seems to be a negative relation between the contract wages and wage drift and the model that was developed in chapter 4 can be used to explain wage bargaining at the level of the firm, after the contract wage is determined. Third, concerning chapters 2, 3 and 5, I note that there are central consultations in the Netherlands, held at least once a year. Since in these consultations there is not only discussion about wages, but also about economic policy in general, these consultations embody the famous "responsibility" of Dutch employers' and employees' organizations. Obviously, federations of employers and employees recognize the relevance of these consultations, although concrete contracts are rarely concluded, but problems regarding externalities can be an important incentive for these federations to participate. Further and most important, the federations still provide industry unions/employers'

18 Unfortunately, this empirical research differs from the theoretical research that I have discussed in section 5.2 and 5.3 , in the sense that strategic externalities and spillover effects are often kept implicit. The reason may be that calculations and estimates of these externalities are difficult to perform. One must calculate spillover effects, the Nash equilibrium, the Nash bargaining solution a.s.o. One notable exception is Frankel and Rockett (1988) who calculate the gain that can be reached from international economic policy cooperation along the lines that I have sketched in section 5.2 . 
organizations with guidelines for their bargaining. This implies that federations "construct" these guidelines in one way or another. If it is assumed that federations try to reach Pareto-efficient guidelines, an efficient bargain model can be used to describe the results of the process of central consultations.

As I have expanded in chapter 1, wage bargaining is one element of this study. The other element is taxes and contributions for social security. The increasing tax burden together with increasing wage cost in the 1970s and partly in the 1980s has caused that these increases in taxes are seen as an imprtant determinant of the wage increases. Part II expands on these issues. I start in the next chapter with key facts regarding the development of taxes and contributions for social security. 


\section{PART II TAXES AND WAGES}

Part II discusses the relation between taxes and wages. Before I start analysing this relation, I present in chapter 6 evidence about the magnitude and the composition of the wedge. Evidence is presented for the Netherlands (at the level of an individual and at the aggregate level) and for a number of $O E C D$ countries (aggregate level). Both the magnitude and the composition of the wedge differs between these countries and in chapter 7 and 81 discuss the question whether $a$ change in the composition of the wedge results in a change in the wage cost. Chapter 7 discusses this question for a perfect competitive labour market and chapter 8 discusses this question is a right-to-manage model of wage bargaining. 


\section{SOME STYLIZED FACTS REGARDING THE DEVELOPMENT OF THE WEDGE AND ITS COMPONENTS}

This chapter discusses the development of the wedge. First the development of the wedge for the Dutch modal enployee is presented, this is the wedge neasured on the miero level. Next, I present data for the Netherlands and these are by definition aggregate data. Special attention will be paid to hhe Oort operation concerning the tax reform, which started in 1989 . Finally the perspective is widened and data for OECD countries is presented in order to analyse whether the situafion in the Netherlands differs from other OECD counhies. 1 conclide first that although the level differs befween micro and macro data, the development of the wedge is similar. Second, a major stift from employers to employees share in the wedge lias taken place. Third, the total wedge is large in the Netherlands, due mainly to a relatively high employees share in this wedge

\subsection{Introduction}

From this chapter onwards, taxes are incorporated in the analysis. This chapter pays in particular attention to the difference between wage costs that must be paid by the employer and the net wages that are received by the employees. This difference is called the wedge. I will discuss two questions. First, how does one measure the wedge and second, to what extent does the wedge (either in composition or in magnitude) differ between the Netherlands and other OECD countries? In the following chapters I will discuss the influence of taxes on both competitive labour markets and in wage bargaining models.

It is well worth paying attention to the measurement and the development of the wedge for several reasons. First, the wedge can be measured at the level of an individual employee or at the aggregate level. Although it is commonest to use aggregate data in the measurement of the wedge, one might nevertheless wonder whether these data are representative for the burden at the level of the individual. Hence, I present the development of the wedge from the perspective of the individual too. I also analyse how the tax reform (Oort-operation) has influenced this wedge on both levels. Second, the Netherlands is well-known for its high taxes and contributions for social security. It is interesting to compare the magnitude and the composition of the wedge between the Netherlands and other OECD countries. Is the magnitude of the wedge indeed high relative to these other countries? Is the composition of the wedge different from other OECD 
countries? And third, the development of the wedge is seen as a main cause of the increase in wages that has taken place in the recent past in the Netherlands (De Ridder (1976), Knoester (1983; 1988), Knoester and Van der Windt (1987), Miljoenennota (various years), Mulder and Van der Ploeg (1990) and Mulder (1990)). The last point will be expanded in chapter 8.

This chapter is organized as follows. Starting with the definition of the wedge in section 6.2 , section 6.3 presents data for the wedge in the Netherlands both for the modal employee and for the aggregate level. In section 6.4 , special attention is paid to the influence of the tax reform that started in 1989. Wedge data for other OECD countries is discussed in section 6.5 and section 6.6 concludes.

\subsection{The measurement of the wedge}

There is in general a difference between the wage costs for the employer and the wage that is received by the employee. Such difference between the price that the demander pays and the supplier receives is called a wedge. The wedge (Wd) on the labour market is defined as the difference between the wage costs for the employer (Wc) and the net wage received by the employee (Wn). This difference is due to three sources: employees' contributions to social security funds (eec) and income taxes (it) paid by employees, but deducted by employers ${ }^{1}$ and employers' contributions to social security funds (erc), also known as payroll taxes. If one adds income taxes and employees' contributions for social security to the net wages, one arrives at gross wages (W). Hence, basically the following relations between wage costs, net wages, the wedge and taxes and premiums for social security exist:

$$
\begin{array}{ll}
W c=W n+W d & W d \geq 0 \\
W d=e e c+i t+e r c & \text { eec, it, erc } \geq 0 \\
W_{c}=W+e r c & \\
W n=W-(e e c+i t) &
\end{array}
$$

Expression (6.1) defines the wedge in absolute and nominal terms, this is the absolute wedge. It is useful, however, to relate the wedge to a wage norm. Therefore one defines

$$
\begin{array}{ll}
W_{n}=\Delta W & \Delta \leq 1 \\
W_{c}=\mathrm{E} W & \mathrm{E} \geq 1
\end{array}
$$

\footnotetext{
1 In the Netherlands income taxes are paid by means of an advance levy from the wages. The final
} settlement followis after the completion of an income tax form. 
and from (6.1) and (6.2) one derives

$$
\begin{gathered}
(1-\Delta)=e e c / W+i t / W \\
\left(E^{-}-1\right)=e r c / W
\end{gathered}
$$

where $\Delta$ is known as the retention ratio and $(\mathrm{E}-1)$ is the ratio of employers' contributions for social security to the gross wage. Further, it follows that $(1-\Delta)+(E-1)=E-\Delta$ equals the ratio of the wedge to the gross wage rate.

An alternative way is to express the wedge as a kind of multiplier: from (6.1) it follows that $\mathrm{Wc}=\mathrm{Wn}(1+\mathrm{Wd} / \mathrm{Wn})$. Hence $(1+\mathrm{Wd} / \mathrm{Wn})$ serves as a mark-up on the net wages. ${ }^{2}$ This idea is used by Mulder and Van der Ploeg (1989), who define the wedge as the ratio of real labour costs to real net wages. Since producers reckon with producers prices to calculate the real wage costs and consumers use consumers prices in their calculation of the real net wage, the ratio of consumers and producers prices will play a role in this definition of the wedge. Further in this definition indirect taxes will appear and, assuming that consumers prices are a weighted average of producers prices and import prices, the exchange rate. Consequently, this definition shows that it is not only changes in taxes that influence the wedge.

I will call this ratio of real labour costs to real net wages the real wedge and derive it as follows. Define $\mathrm{t} 1=\mathrm{erc} / \mathrm{Wn} ; \mathrm{t} 2=\mathrm{eec} / \mathrm{Wn}$ and $\mathrm{t} 3=\mathrm{it} / \mathrm{Wn}$; then from (6.1) one sees

$$
W c=W n(1+t 1+t 2+t 3)
$$

If one splits nominal wage costs into a real part (wc) and a (production) price component (py) and net wages into wn and (consumption) prices (pc), equation (6.4) becomes

$$
\underline{w c} \cdot p y=w n \cdot p c(1+t 1+t 2+t 3)
$$

The real wedge (rwd) then is given by $\mathrm{rwd}=\mathrm{wc} / \mathrm{wn}$, which equals

2 An example makes clear that the definition of the wedge via $\mathrm{Wc} / \mathrm{Wn}$ and via (Wc-Wn)/W are both sides of the same picture. Assume wage costs equall 110 units and assume that employers" contributions equal 10 units and employees' taxes equal 20 units. Then using ( $\mathrm{Wc}-\mathrm{Wn}$ )/W, the wedge $=0.3,30 \%$ of the gross wages is due to taxes. Since $W=(1 / \Delta) W n$, this means that wedge/net wage ratio equals $(0.3 / 0.8)=$ 0.375 . Hence, net wages have to be multiplied by $1.375=1+$ [wedge/net wages] to get wage costs. This multiplier is exactly equal to $\mathrm{Wc} / \mathrm{Wn}$. 


$$
w w d=(p c / p y)(1+t 1+12+13)
$$

According to this definition wn must be multiplied by $(\mathrm{pc} / \mathrm{py})(1+\mathrm{Wd} / \mathrm{Wn})$ to find $\mathrm{wc}$. Assume further that consumption prices are a weighted average of production prices and import prices denoted in the home currency ( $\mathrm{p}^{*} \mathrm{e}, \mathrm{e}=$ exchange rate; that is the number of units of home currency to be traded for one unit of foreign currency) with weights $\beta$ and $1-\beta$, multiplied by $1+(t 4)$, where $t 4$ is the indirect tax rate, then

$$
p c=p y^{\beta}\left(p * k^{1-\beta}(1+14)\right.
$$

Substituting (6.7) into (6.6) and using logarithms one derives

$\ln w w d=(1-\beta) \ln (p * e / p y)+\ln t 1+\ln t 2+\ln t 3+\ln t 4$

In (6.8) the variables that influence a change in the real wedge are determined. It follows that apart from a rise in payroll or income taxes, an increase in indirect taxes or the (real) exchange rate can augment the difference between real wage costs and net real wages. A depreciation of the exchange rate increases consumption prices and therefore real wages decrease, while real wage costs do not change. Hence, the wedge increases. More important in using this formula, however, is that the influence of indirect taxes and the terms of trade can easily be derived (see also Mulder and Van der Ploeg 1989).

Until now, only the average wedge is discussed. One can also calculate a marginal wedge by dividing the change in the wedge by the change in the gross wages. However, since there are some discontinuities in the tax system (caused by the system of the brackets) the calculation of the marginal wedge is liable to the starting point: the result of a small change in income whereby the taxpayer remains in the same bracket will differ from the result of a small change in income that causes the taxpayer to enter the next bracket. Consequently, one must choose an appropriate increase in income. Krapels and Van Ravestein (1987) take for example an increase of $7.5 \%$. Attention for the marginal wedge increases (for example the OECD (1994) focuses nearly exclusively on the marginal wedge) and sometimes the marginal tax rate is included in empirical research (Graafland, 
1991). ${ }^{3}$ However, since one of the aims of this chapter is to calculate the wedge both at the aggregate and at the micro level, I focus on the average wedge.

\subsection{The development of the wedge in the Netherlands 1960-1993}

In order to analyse the development of the wedge, I used the definition in equation (6.3). Hence, I collected data concerning employers' contributions to social security funds, employees' contributions to social security funds and income taxes paid by employees. In most research the national accounts are used as the source of information about taxes and social security contributions when measuring the wedge. These aggregate figures provide a measure at the macro-level. However, since these figures can only show a rough and average development, it might be interesting to measure the wedge also at the level of an individual. I will start with the latter and thereafter discuss the aggregate figures.

It will be clear that the wedge differs between individuals. Taxes and premiums depend on income and in the Dutch system there is a maximum income level above which no premiums are indebted. Consequently, measuring the wedge at the level of individuals boils down to calculating taxes and premiums for a certain type of household with a certain income and then calculating the ratio of the wedge to the gross wage. Along these lines, the Dutch Ministry of Finance has been able to measure the wedge for several income groups and several types of households (Krapels and Van Ravestein, 1987). They present data covering the period 1960-1987 and I have first reconstructed and second updated the series for the period 1988-1993, using the same method. ${ }^{4}$ Figures $6.1-6.3$ show the results for a family type with a modal income and having 2 children. I will discuss these results below.

3. The relation between the marginal wedge and the wage rate is controversial in the literature. Graafland (1991) argues that an increase in the marginal wedge implies that the value of a wage increase decreases. This will have a downward effect on the wage rate. The OECD, on the other hand, argues that high taxes have an upward effect on the wage rate and they use the marginal wedge to illustrate this.

4 The calculations are arbitrary, since one has to make assumptions concerning interest deductions, travelling costs, etc, for the individual. This means that given a certain gross wage, one has to calculate the corresponding net wage and wage costs using tax tables and schemes for premuiums for social security, both for employers and for employees. In the calculations I abstract from specific circumstances such as for example deductions for interest payments on mortgages. More details are provided in Appendix $6 \mathrm{~A}$. 
Figure 6.1 Employers' part of the wedge

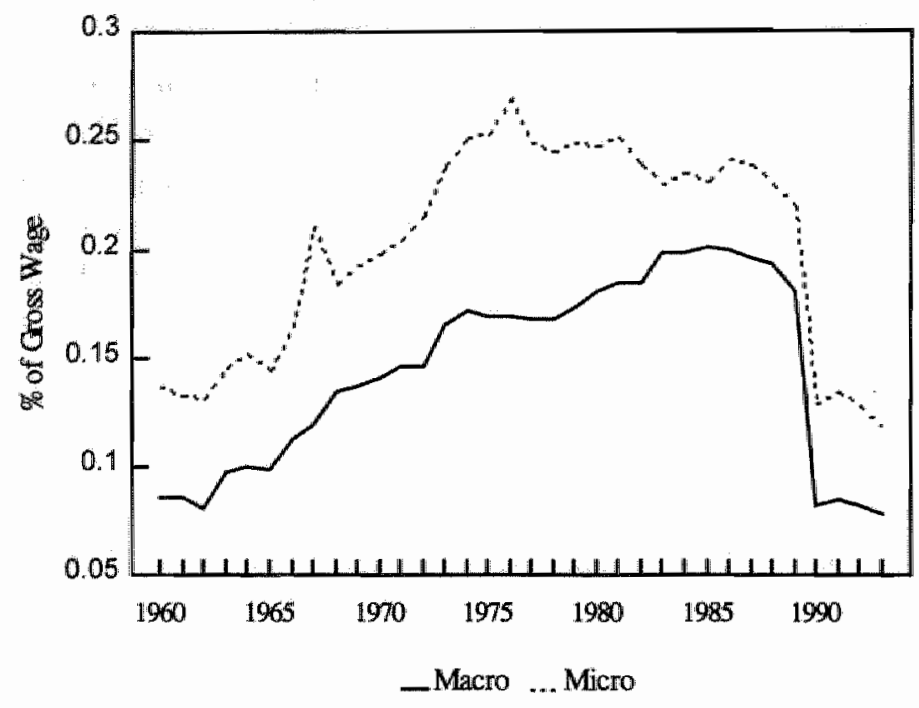

Figure 6.2 Employees' part of the wedge

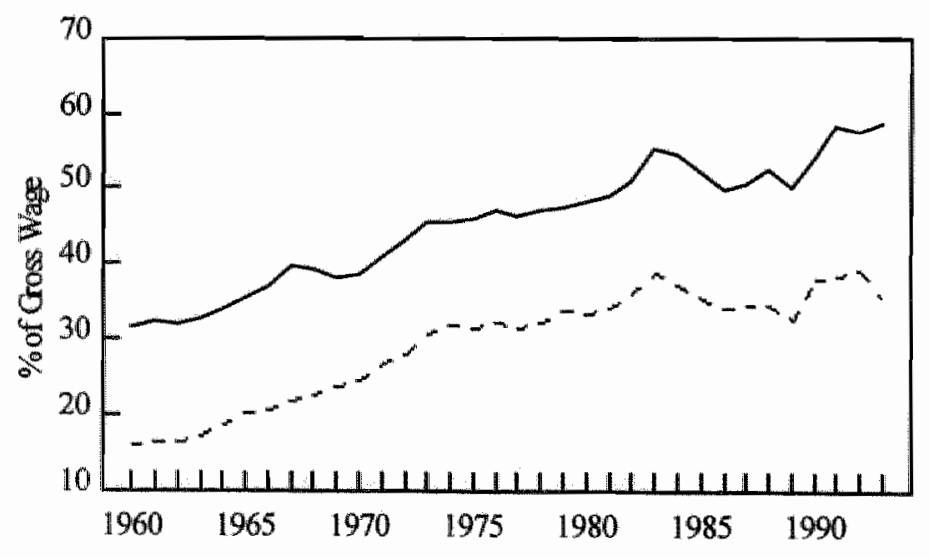

-. Micro - Macro 
Figure 6.3 Total wedge

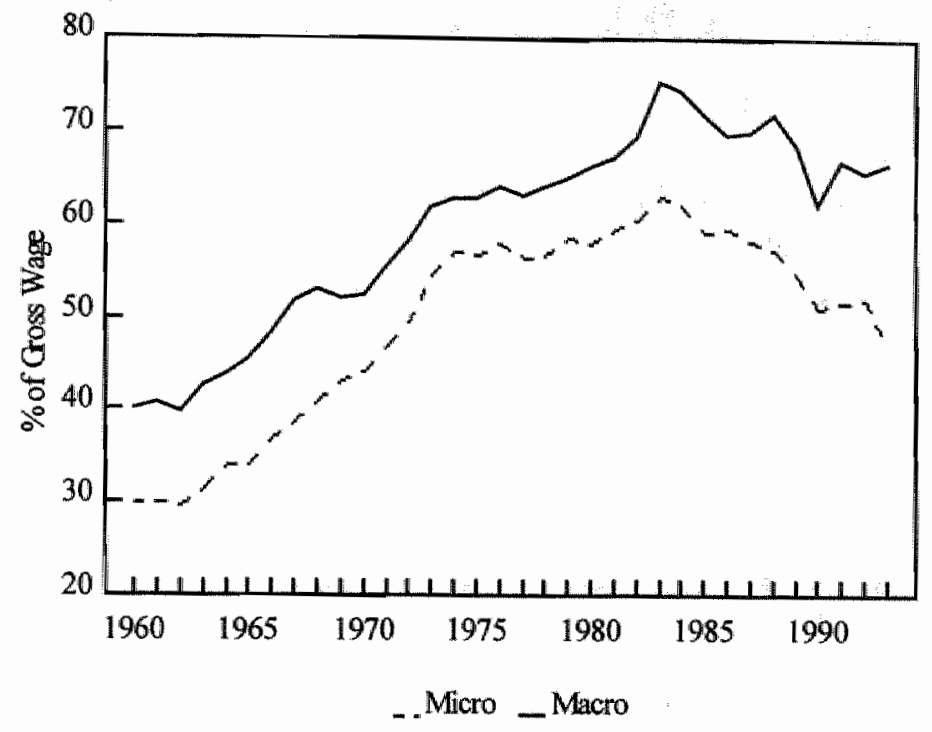

Sources: The micro-data are based on a method that was developed by F.J. Krapels and A. wan Ravestein (1987). The macro-data have been derived from the various volumes of the national accounts.

When the wedge is measured at an aggregate level (the macro-wedge), the main problem is that the national accounts in the Netherlands only provide data on taxes at the level of families. Hence, aggregate figures for wage and income taxes of employees are not published. For that reason I have taken 'families' as an approximation of employees, which is in line with other empirical research in this field. ${ }^{5}$ Social security contributions are split up into employees' and employers' parts. Further, since Krapels and Van Ravestein have excluded pension premiums, I have excluded them too in the calculations for reasons of comparability. The results of these calculations are also presented in Figures 6.1-6.3.

These figures illuminate some interesting developments. First, in the period 19601993 the total wedge has increased from $42 \%$ to $66 \%$ (macro-level, percentage taken of gross wages). To be clear, this means that in 1993 wage costs were 2.57 times the net

5. e.g. Brandsma and Van Der Windt (1983), Knoester and Van Der Windt (1987), Graafland (1990) and Lever (1993). 
wages. ${ }^{6}$ At the micro-level the wedge developed from $30 \%$ to $47 \%$. Second, from Figure 6.3 it is clear that the wedge increased from 1960-1983 and thereafter it decreased. It reached an all-time high in 1983 when the wedge was equal to $75 \%$. The same holds for the micro-level, with an all-time high of $63 \%$.

A striking feature is the major changes that took place from 1989 to 1991 . As De Kam (1996) has extensively discussed, the Oort operation started in 1989. A major change was the significant shift from employer to employee contributions of part of the premiums for social security and this operation was accompanied by an increase in gross wages. This resulted in a drastic shift in the composition of the wedge in 1989 and 1990. The Figures show these shifts clearly, especially in the data for employers. In the next section I elaborate on the influence of the tax reform on the wedge. At the macro level, employees' premiums and taxes increased from $50 \%$ to $58 \%$ of gross wages in the period $1989-1991$. During that period employers' premiums decreased from $18 \%$ to $8 \%{ }^{7}$

Apart from these shifts, some interesting developments can be observed. First, the employees' part of the wedge shows an increasing trend over the whole period, while employers' contributions stabilise from 1975 onwards. Thus a shift from employers' to employees' contributions has taken place during the last fifteen years. If one compares the share of employees' premiums (excluding taxes) with the share of employers' premiums, one notices an increase from $11 \%$ to $32 \%$ in employees' contributions during the period $1960-1993$ and an increase in employers' contributions from $8 \%$ in 1960 to $17 \%$ in 1974 , followed by stability till 1989 (aggregate figures). Note that this expresses the shift in statutory burden that has taken place from employers' to employees' contributions.

Second, contrary to what one finds for the employers' case, the employees' ratio of premiums to gross wages at the micro level is lower than at the macro level. This reflects two opposite forces. First, in the Dutch system there is a maximum income for the levying

6 This does not follow immediately from the figures that are given in the text. It is calculated as follows. From $W e=W n+w e d g e$ it follows that $W c=W n+0.66 W$. Since $W n=\Delta W$ and $\Delta=0.42$ (this follows from the basic data; see also Figure 6.2), $\mathrm{Wc}=\mathrm{Wn}(1+(0.66 / 0.42)$. Hence, $\mathrm{Wc}=\mathrm{Wn}(1+1.57)$.

7 In the Netherlands, there is discussion about the way the results of the Oort operation must be incorporated in the data. After the reform, the CBS lowered the employers'premiums and added the taxable compensation ("overhevelingstoeslag") to the gross wages of the employees, see the national accounts. Obviously, they argue that since the taxable compensation will be reduced in due timue, it is preferable to add it immediately to the gross wage. The resillt is a major decrease in employers' part of the wedge as can be seen in Figure 6.1. The $\mathrm{CPB}$, however, considers the taxable compensation as an employers'premium and hence does not increase the gross. wages. The CPB argues that Oort did not change anything, because employers are obliged to pay the taxable compensation. Then this major drop does not occur any longer, see Centraal Economisch Plan. Since I used the aggregate data of the CBS as a "benchmark" I used their method in the updating of Krapels and Van Ravestein. I thank mr. R. van Opstal of the CPB for additional information. 
of premiums. This income is slightly higher than the modal income, so for the family with the modal income this maximum income does not matter. However, for all incomes above the modal income, the ratio of premiums to gross wages will decrease when income increases. Second, the employees' part of the wedge also measures income taxes for which a maximum income obviously does not hold. On the contrary, the tax system in the Netherlands is progressive, implying that families with an income above model pay relatively more taxes. The data indeed show that the difference between the macro level and the micro level is mainly caused by a difference in the taxes/gross wage ratio.

Third, the majority of the wedge consists of employees' contributions for taxes and social security: in 1993 the wedge is 66\%: employees" part is 58 percentage-points (of which 26 percentage-points consist of taxes) and only 8 percentage-points are employers' contributions. Table 6.1 summarizes some exemplary facts concerning the wedge during the period 1960-1993.

Table 6.1 Stylized facts about the development of the wedge (in percentage/100 of gross wages) in the Netherlands, period $1960-1993^{8}$

\begin{tabular}{||l|l|l||}
\hline & micro level & macro level \\
\hline wedge in 1960 & 0.30 & 0.40 \\
& 0.16 employees & 0.32 employees \\
& 0.14 employers & 0.08 employers \\
\hline wedge in 1993 & 0.47 & 0.66 \\
& 0.36 employees & 0.58 employees \\
& 0.11 employers & 0.08 employers \\
\hline all time high & $0.63(1983)$ & $0.75(1983)$ \\
& 0.39 employees & 0.55 employees \\
& 0.24 employers & 0.20 employers \\
\hline average over 1960-93 & 0.50 & 0.60 \\
& 0.30 employees & 0.45 employees \\
& 0.20 employers & 0.15 employers \\
\hline
\end{tabular}

Source: own calculations.

I have plotted both the micro-wedge and the macro-wedge in the same figure. This may suggest that one can easily compare these figures. Caution is, however, warranted. Consider the employees' part. I have calculated the micro burden by using the tax tables

8 Thus: 100 times a figure in Table 6.1 gives the percentage of gross wages. 
and the tables for premiums for social security and applying them to a person having a modal income. Hence the micro-wedge measures the average statutory burden on a certain class of income, the modal income. To calculate the macro-wedge, I have traced the total amount of taxes paid by households and premiums not paid by employers, and divided this amount by the total gross wages received by households. Consequently, the macro-wedge measures the average "collective" burden per guilder gross income that has been earned in the private or in the public sector. In a sense this is an approach of the statutory burden at the macro-level. In comparing these figures, four fallacies need to be stressed, however. First, note that in the macro-wedge all payments for taxes and premiums are included, not only the payments of employees. Taxes and premiums that are paid by people that receive some kind of benefit or pension is included in the tax payments, but their income is not included in total gross wages. Hence, this provides an upward bias in the macro-wedge in comparison to the micro-wedge. Lack of reliable data does not permit to do more precise calculations in this respect. Second, the macro-wedge measures the taxes that have actually been paid. It is obvious that because of legal and illegal tax deductions the taxes that are actually paid differ from the taxes that I have levied according to the tables (cf. footnote 4). This produces an upward bias in the micro-wedge. Third, in the Dutch system, taxes are progressive and premiums for social security contributions are degressive (i.e. proportional to a certain maximum). Both the progressivity and the degressivity are fully incorporated in the macro-figures, but not in the micro-wedge, since modal income is not liable to the highest tax-tariff and is slightly below the maximum income for levying the premiums. The influence on the comparison of the micro and the macro figures is ambiguous. Fourth, the modal income is constructed by applying indices for contract wages, while the total gross wage in the national accounts is the sum of the wages that is actually paid. ${ }^{9}$ As far as the development of the modal income differs from the development in total gross wages, there will be a bias. One reason may be the effect of tax shifting on wages. Assume, for example, that tax shifting occurs. In so far as the effects of tax shifting with respect to the total gross wages differ from the effects on the modal wage, this will cause an extra complication too in comparing the macro and the micro-wedge. To summarize, only when one flat tax rate exists, and when tax deductions are simply applicable and unambiguous (e.g. as in the case of a lump-sum tax deduction), and one can split in employees' households and other households, and when the development of the modal income exactly matches the development of total gross wages, will the macro and the micro wedge be identical. These

9 The Central Bureau of Statistics in the Netherlands publishes indices for the contract wages. If one knows the gross income for the modal employee in a certain year, one can "translate" the indices into yearly incomes. Since Krapels and Van Ravestein provide income data, I could reconstruct that they have used this method too and update the series. 
problems are less severe in the employers' part of the wedge. Premiums only concern employers and there are no deductions. Hence, in this case the difference between the macro and the micro-wedge is mainly due to differences in the development of the modal income and total gross wages and the degressivity of the premiums system.

\subsection{The influence of the tax reform of 1989}

Especially from Figure 6.1, it can be seen that in 1989/1990 a major tax reform has taken place. This tax reform was prepared by a committee under the guidance of $\mathrm{C}$. Oort and hence the tax reform is also called the Oort operation despite the fact that the ideas of the Oort committee were followed only partly by the Cabinet. The details of the ideas of the Oort committee on tax reform are extensively discussed in De Kam (1996). The revision of the tax system became effective as from 1 January 1990. With respect to the magnitude and the composition of the wedge, I will make the following remarks.

1) One of the central ideas of the Oort committee was to make the tax system less progressive. The Cabinet decided to cut the top tax rate (from $72 \%$ to $60 \%$ ), while on the other hand the rich menu of tax deductions that existed in the Netherlands was reduced substantially. It was expected that both measures would have a slightly decreasing effect on the magnitude of the wedge.

2) Concerning the composition of the wedge, the Oort committee proposed to shift a number of employers" premiums to employees. ${ }^{10}$ Table 6.2 shows this shift.

To compensate employees for this increase in their statutory burden, "employees received a taxable compensation ("overhevelingstoeslag") by the amount of the contributions shifted" (De Kam, p. 196). I have added this compensation to the calculated "gross" wage (that was calculated using the indices and the Krapels and Van Ravestein income data) to calculate the "new" gross wages." It is obvious then that in the figures this shift will particularly affect the employers' burden in a downward direction, while the effects on employees will be low. The total wedge will, however, also show a decrease. These effects are illustrated in Figures 6.1 - 6.3.

10. According to De Kam, the arguments for this shift were rather technical. The committee thought that it was inconvenient to have some contributions paid by employees and others by the withholding agents.

11 This seems in accordance with the method that is used in the national accounts. Unfortunately, howewer, nobody at the Central Bureau of Statistics could explain how they treated this tax reform in their national accounts and in their figures for the wage index (see also footnote 7). 
Table 6.2 The shift from employers' to employees' contributions in 1989/1990

\begin{tabular}{|l|c|c|c|c||}
\hline \multirow{2}{*}{ type of social insurance contribution } & \multicolumn{2}{|c|}{1989 premium \% } & \multicolumn{2}{c|}{1990 premium \% } \\
\cline { 2 - 5 } & employer & employee & employer & employee \\
\hline Old Age (AOW) & 0 & 10.80 & 0 & 14.30 \\
\hline Widows (AWW) & 0 & 1.20 & 0 & 1.25 \\
\hline Disability (AAW) & 6.20 & 0 & 0 & 1.15 \\
\hline Special provisions for sickness (AWBZ) & 5.20 & 0 & 0 & 5.40 \\
\hline & 11.40 & 12 & 0 & 22.10 \\
\hline
\end{tabular}

Source: Ministerie van Sociale Zaken en Werkgelegenheid, Sociale Nota, 1995, Appendix 12.

Note that the Oort operation accentuated the shift in the composition of the wedge which already begun in the mid-seventies. An analysis of the statutory burden shows that employees' premiums for disability insurance (WAO) increased from $5.58 \%$ in 1979 to $17.25 \%$ in 1983 , while employers" premiums for disability insurance decreased from $6.9 \%$ to $3.65 \%$ over the same period (Sociale Nota, 1995, appendix 12, p 172). ${ }^{12}$ Further note that in 1988 premiums for children's allowances (about $2 \%$ ) were shifted from employers to the government and that from 1990 onwards total premiums for AAW (about 6\%) have been shifted from employers to employees.

\subsection{A comparison between the Netherlands and OECD countries}

Is the wedge in the Netherlands high in comparison to other OECD countries? This intriguing question governs the discussion in the Netherlands, now and then. To calculate the wedge for other OECD countries I have used the same method of measurement as for the Dutch aggregate data. Data for nine OECD countries were available over the period 1968-1992 in the National Accounts of the OECD (1968-1987) and in the Financial Statistics of the United Nations (1988-1992). ${ }^{13}$

Figures $6.4-6.8$ present the development of the total wedge and of the various parts of the wedge like income taxes and social security contributions for employers and for

Premiums are expressed as a percentage of the contributions base (premiegrondslag).

13 These countries ane Belgium, Canada, France, Germany, Italy, Japan, Sweden, the UK and the USA. 
employees. The Figures in the main text compare averages for the Netherlands and for nine OECD countries. In appendix 6C-6G I compare the Netherlands with each of the nine OECD countries. Before going into more detail in these figures, I draw attention to this reservation. One problem in comparing international data is that the definitions may differ. For example, if social security contributions are fiscalized, then part of the income taxes is really payments for social security. This hampers making firm conclusions about the composition of the wedge.

Figure 6.4 The development of the total wedge; average for the Netherlands and for 9 OECD countries ${ }^{14}$

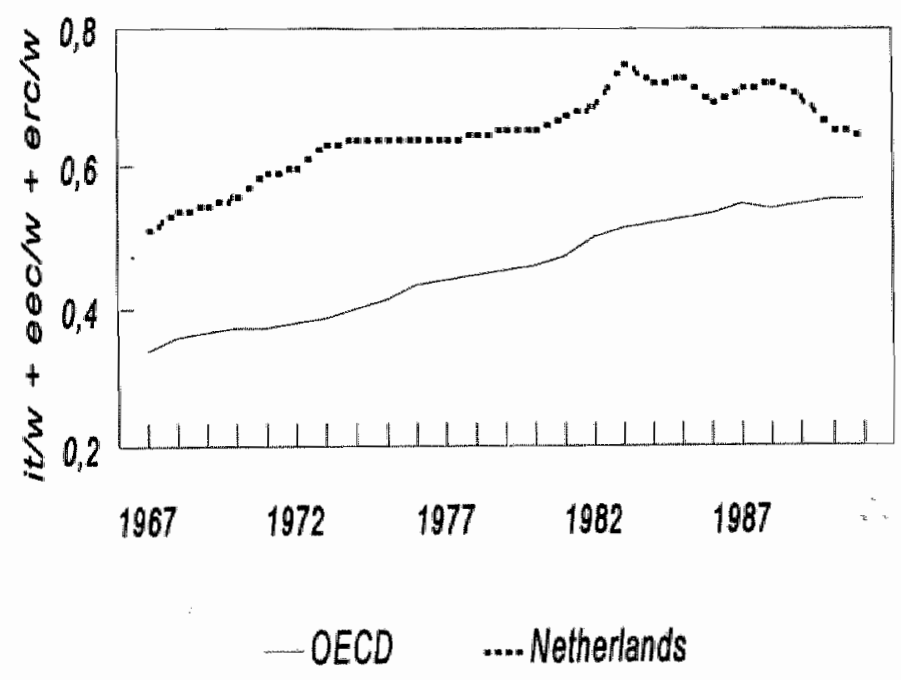

I start with the total wedge and the following picture can be sketched. The wedge in the Netherlands is clearly higher then the average of the, $O E C D-9$, but the difference is decreasing. ${ }^{15}$ Compared to the Netherlands, Japan, the USA, the UK and Canada are the countries with the lowest wedge. On the contrary, Belgium, Italy and Sweden belong to the group of countries with a high wedge. The wedge in Germany and France converges to the level in the Netherlands. This picture still holds when one looks at total contributions for

14 Note that the $O E C D$ average is the awerage of only the nine $O E C D$ countries that I have taken into account.

I5 By the OECD-9 I mean the 9 OECD countries that I have taken into account. 
social security (not shown), except for the French premiums that continued to increase in the early $90 \mathrm{~s}$, while the Dutch premiums have decreased.

If one looks at the various parts, one sees that employees' contributions for social security in the Netherlands exceed those of the other nine OECD countries that are taken into account (Figure 6.5). Until 1989, employers' contributions for social security exceeded those of the other countries, except for Belgium, France, Italy and Sweden. After the shift due to the Oort operation, employers' contributions are either lower or about the same as in the other OECD countries (Figure 6.6) and are clearly below the OECD-9 average.

Figure 6.5 The development of employees' contributions to social security; average for the Netherlands and for 9 OECD countries

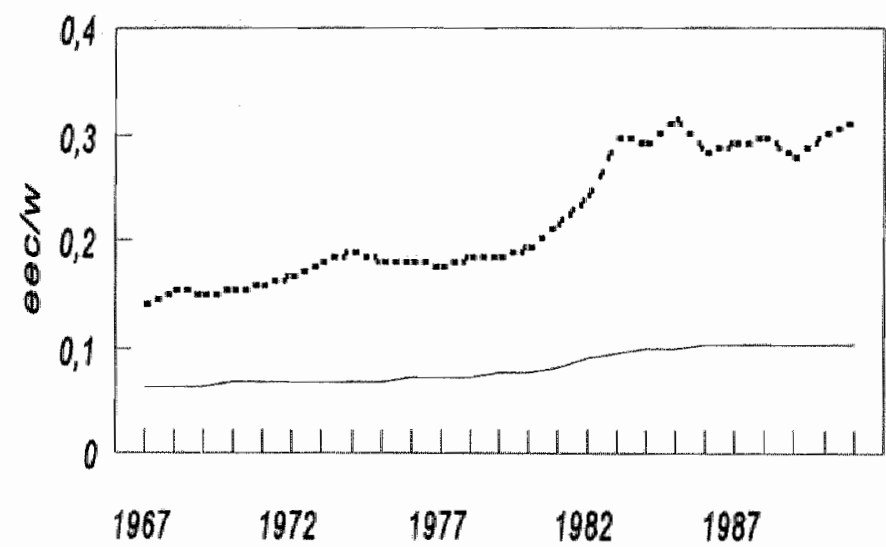

OECD $\quad$.... Netherlands 
Figure 6.6 The development of employers' contributions to social security; average for the Netherlands and for 9 OECD countries

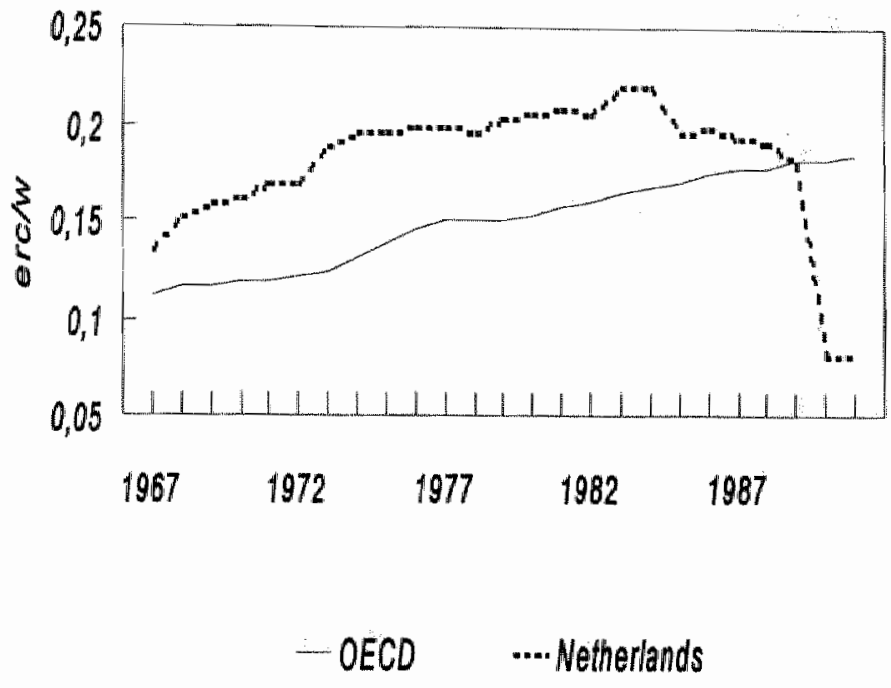

Figure 6.7 shows the ratio of income taxes/gross wages. During the second half of the 1980 s, Dutch income tax ratio has converged to the OECD-9 average. Dutch income taxes are high relative to France and Japan. Income taxes in Belgium, Sweden and recently Italy, exceed the Dutch ones. Dutch income taxes are rather closely related to those in Germany. Figure 6.8 shows finally that employees' part of the wedge (income taxes plus social security contributions) is relatively high in the Netherlands in relation to other OECD countries. 
Figure 6.7 The development of average income taxes; average for the Netherlands and for 9 OECD countries

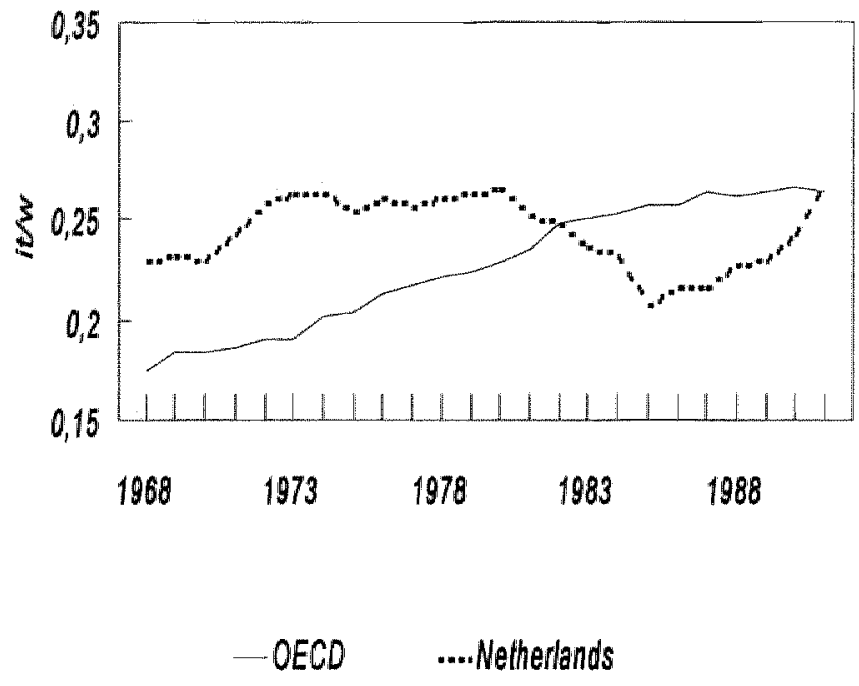

Figure 6.8 The development of employees' part of the wedge; average for the Netherlands and for 9 OECD countries

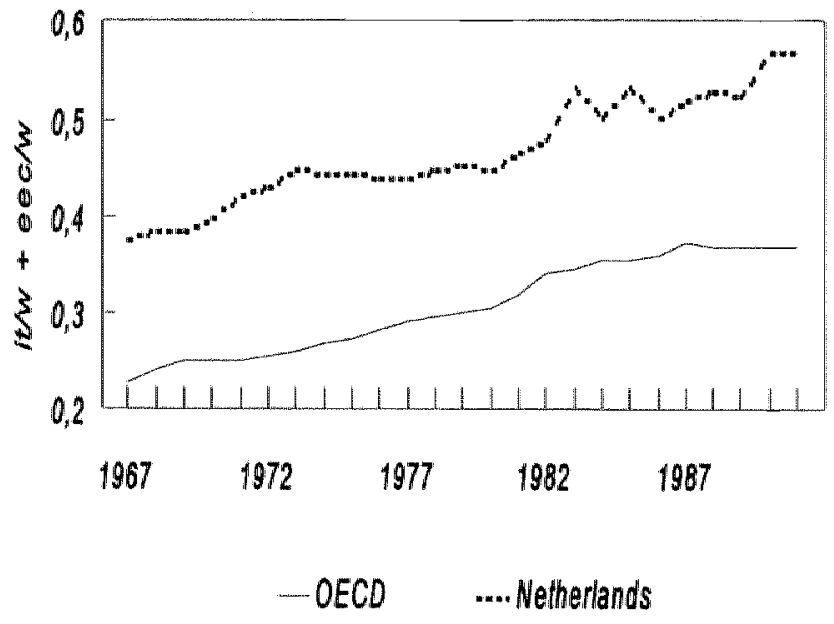


Table 6.3 summarizes these findings by classifying the countries according to the magnitude of the wedge.

Table 6.3 Classification of countries according to the magnitude and the composition of the wedge (per 1992)

\begin{tabular}{|l|l|}
\hline countries in consideration & $\begin{array}{l}\text { Belgium, Canada, France, Germany, Japan, } \\
\text { Sweden, United Kingdom, United States of } \\
\text { America, Italy. }\end{array}$ \\
\hline countries with a wedge $>\mathrm{NL}$ & Belgium, Italy, Sweden \\
\hline $\begin{array}{l}\text { countries with employers" premiums }>\mathrm{NL} \\
\text { countries with income taxes plus } \\
\text { employees' premiums }>\mathrm{NL}\end{array}$ & Belgium, France, Germany, Italy, Sweden. \\
\hline countries with income tax burden $>\mathrm{NL}$ & Belgium, Italy, Sweden \\
\hline
\end{tabular}

From Table 6.3 I conclude that the wedge in the Netherlands is high relative to other OECD countries. This is mainly due to high direct taxes and employees' contributions for social security.

The OECD (1994) and the CPB (1995) are two recent studies that also have calculated the wedge for various OECD countries. The CPB study presents data for $\mathrm{OECD}$ countries for 1993 only. The OECD study presents data for a few years within the period 1978-1992. Both studies present data at the micro level, but their calculation of the tax wedge differs from the one that is used in this chapter. The OECD study includes consumption taxes in the calculation of the wedge because the OECD defines the tax wedge as the difference between the labour costs and the consumption that can be financed from work. This is an unusual definition, that is to say unusual in empirical research, and it is a kind of mixture between the standard definition and the definition of the real wedge. Further, the $\mathrm{OECD}$ focuses on the marginal wedge. The CPB defines the average wedge as the difference between wage costs and disposable income expressed as a percentage of gross wages. Since disposable income includes family and housing benefits, this definition differs from mine and implies a lower wedge: for 1993 the wedge according to my calculations equals 0.47 as opposed to 0.44 according to the CPB calculations. This CPB definition has an attractive side because the wedge is corrected for benefits received. However, for the calculation of these benefits it is assumed that the family lives in a rented 
house and the age of the children is fixed at 7 and 11 years (CPB (1995), p. 10). One might wonder whether the method of Krapels and Van Ravestein (assuming no benefits) is worse in this respect. In any case, for the construction of time series the last method is to be preferred above the CPB method, not only because of the availability of data, but because it also avoids a careful study of the frequently changing arrangements concerning these benefits.

Notwithstanding the difference in definitions, one can compare some of the findings in this chapter with the OECD and the CPB results. The decline in the employers" social security contribution rate is confirmed in the OECD data: the Netherlands shows the largest negative change in this rate between 1981 and 1991. The CPB also adduces a low average wedge for the UK (they do not include Japan, US and Canada). As in this chapter's results, Germany is close to the Netherlands and Italy shows a higher wedge, together with Belgium.

\subsection{Conclusions}

This chapter discussed the measurement and the development of the wedge. For the Netherlands, data for the wedge at the aggregate level and at the level of the modal employee are presented. Special attention was paid to the tax reform of 1989/1990. Further, data (at the aggregate level) for the Netherlands were compared to other OECD countries. One can conclude first that although the level differs between micro and macro data, the development of the wedge is similar: an increase in the period 1960-1983 and then a decrease in the period 1984-1993. Second, a major shift from employers" to employees' share in the wedge has taken place. This shift already started in the late seventies and was reinforced by the tax reform that started in 1990. Third, in comparison to other OECD countries, the total wedge is large in the Netherlands. This is mainly due to a high tax rate and high employees' share in the wedge.

One may wonder whether the difference in the magnitude of the wedge matters. In particular, one may question the impact of the existence of this wedge on the wage rate and on employment. Further, given the difference in the structure of this wedge between the OECD countries, one may wonder whether the composition of the wedge matters in this respect. In the following chapters I return to these questions. The next chapter analyzes these questions in a market setup and chapter 8 discusses these questions for wage bargaining models. 


\section{APPENDIX 6A A note on the wedge data for an individual employee}

As I have argued in the main text, data about taxes and social security contributions at the level of individuals is harder to gather than aggregate data. Nevertheless, Krapels and Van Ravestein have tried to calculate the wedge for a typical individual. Basically, in order to calculate the wedge and the employers' and employees' burden, one has to answer the question how much of gross income is paid for direct taxes (wages and income taxes) and for social security contributions. Krapels and Van Ravestein have simply reconstructed the payroll form of a typical employee. They have used the following scheme:

\section{Gross wage}

less: net contributions for social security

=Taxable income

less: tax-free income

$=$ Taxable sum

Next with the help of the tax tariffs, they have calculated the amount of taxes that has to be paid by this employee. To calculate the tax burden, they divide the amount of taxes by the gross wage.

Note that this is a rough approach of the tax burden and it is biased upwards. For, the Dutch tax system is characterized by a great number of possibilities for tax reduction. For example, interest payments for loans and mortgages are deductible, travelling expenses can be deducted, etc. However, Krapels and Van Ravestein have abstracted from these kinds of deductible costs (which is of course quite reasonable for a time series) and consequently their tax burden is about the maximum tax the taxpayer in question has to pay.

Employers' contributions have been calculated by using the various tariffs that are imposed on them.

Since the method of Krapels and Van Ravestein (KR) is well documented, I could follow their method. To update these series, I started to reconstruct the data from KR. However, I did not succeed completely, small differences remained. I then used my own results to construct a time series for the whole period (1960-1993). In this sense, my series is not an updated version of $\mathrm{KR}$, but a new series based on their method.

I show the calculation for a married man, earning a modal income and having two children, with a wife that is not working. 
Apart from the tax tables (I used the Kluwer editions and would like to thank Kluwer for their hospitality to enable me to copy old volumes of their tax guides), I have used "De Kleine Gids voor de Nederlandse Sociale Zekerheid" and the "Sociale Nota" from the Ministry of social affairs and employment as the main sources. 
APPENDIX 6B A note on the wedge data in the national accounts.

Aggregate figures for wage and income taxes of employees are not published in the Netherlands, but since the national accounts provide a good overview of the taxes, social security contributions and expenditures that flow via the families, I have taken "families" as a proxy for employees. The figures for the direct taxes can be found in the account for the secondary income distribution. Note that these are direct taxes paid by the families. Hence corporate taxes are excluded.

Detailed information about social security payments (and benefits) can be found in the series of S-Tables that are incorporated the national accounts. Both figures for total premiums and the employees' and employers' part are published. Note that retirement premiums and the so-called imputed premiums are excluded. Consequently the remaining premiums are related to insurance against disability (25\%), against illness (25\%), "against" old age (25\%), against widow(er)hood and premiums for children's allowance (25\%).

Figures for the wages and the salaries can be found in the national accounts, account for families, primary income distribution. If social security contributions paid by employers is added, one finds the total wage costs. 
Appendix 6C

The development of the total wedge; the Netherlands vs 9 OECD countries
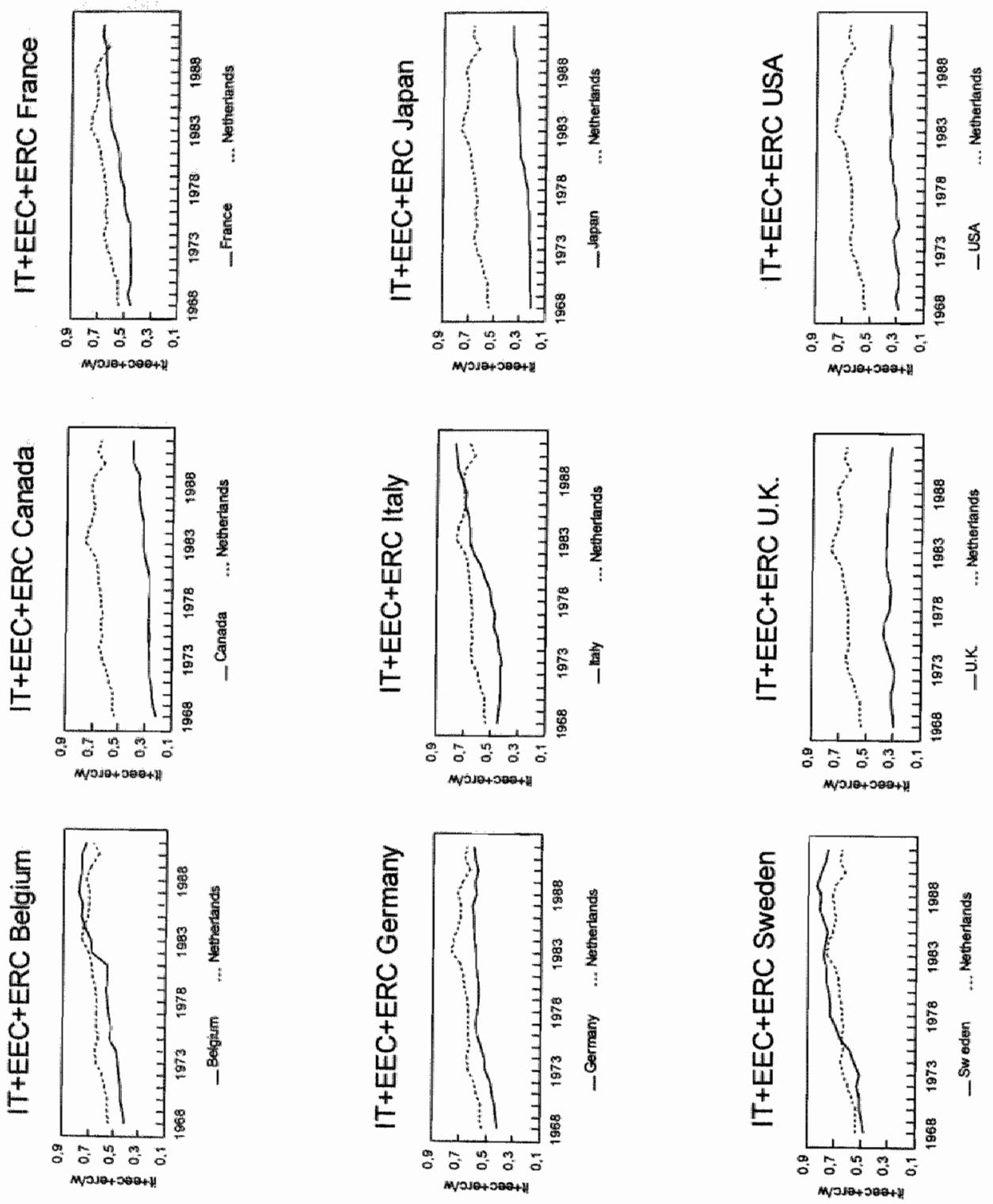
Appendix 6D The development of employees' contributions to social security; the Netherlands vs 9 OECD countries
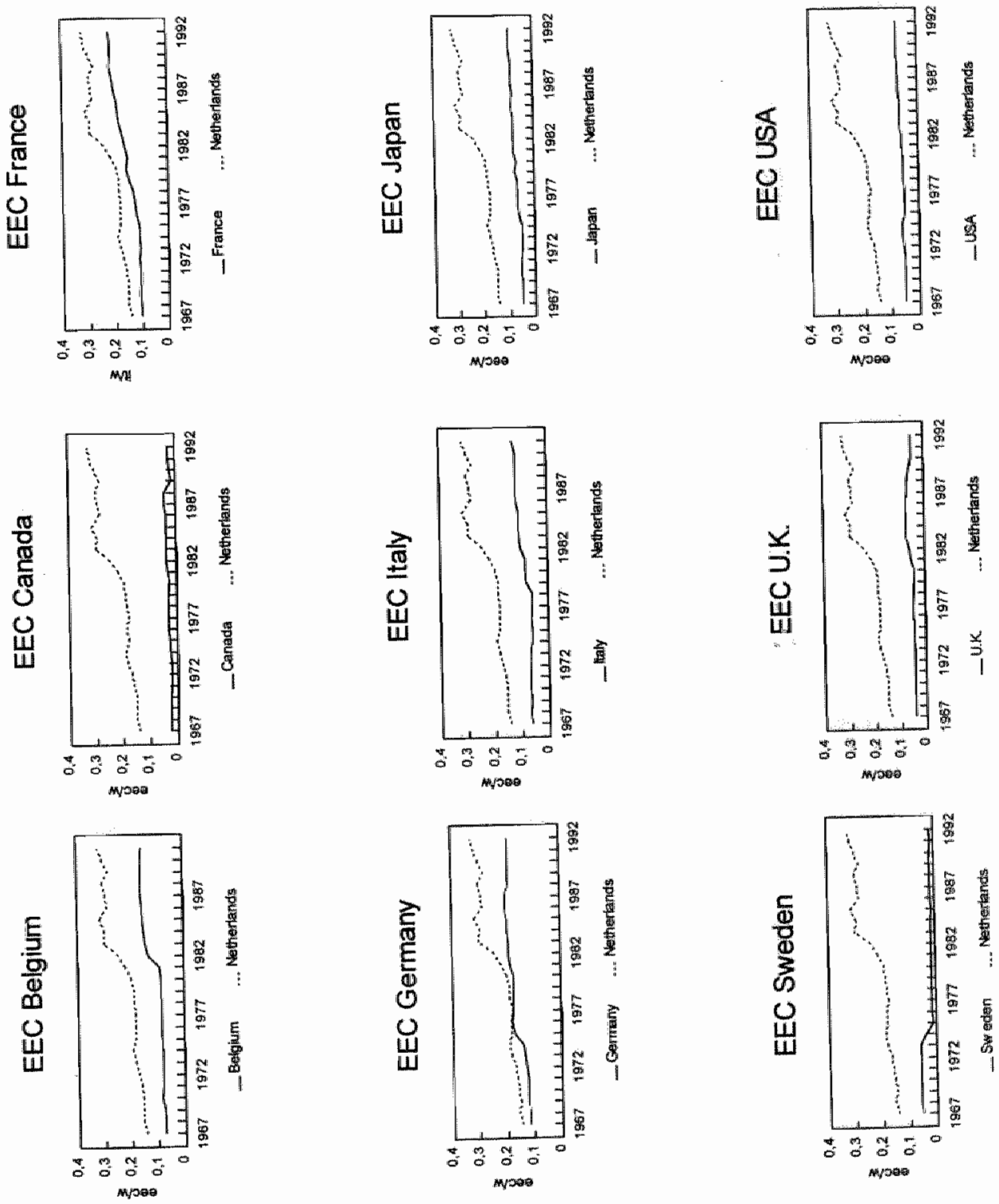
Appendix 6E The development of employers' contributions to social security; the Netherlands vs 9 OECD countries
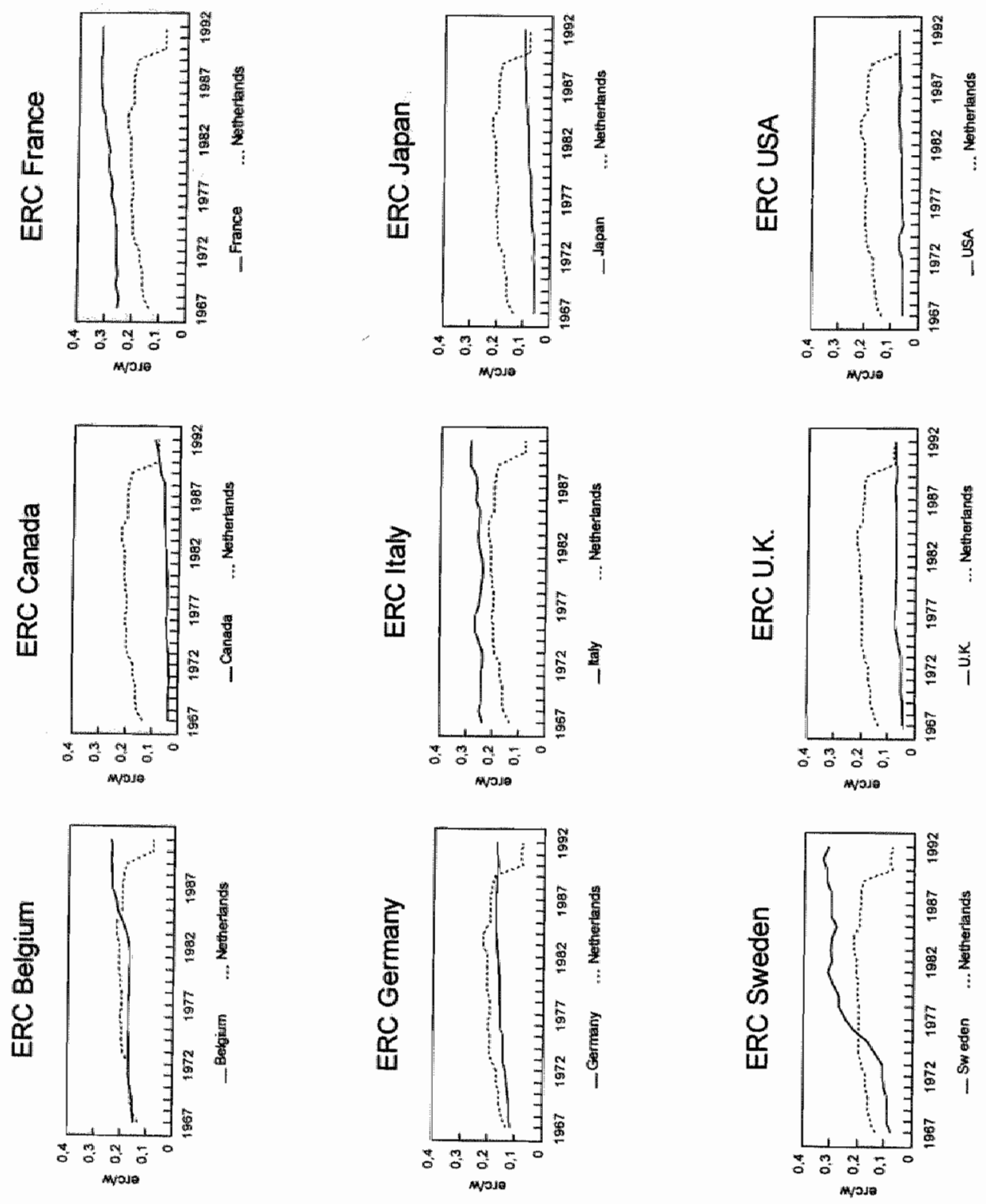
Appendix 6F

The development of average income taxes; the Netherlands vs 9 OECD countries
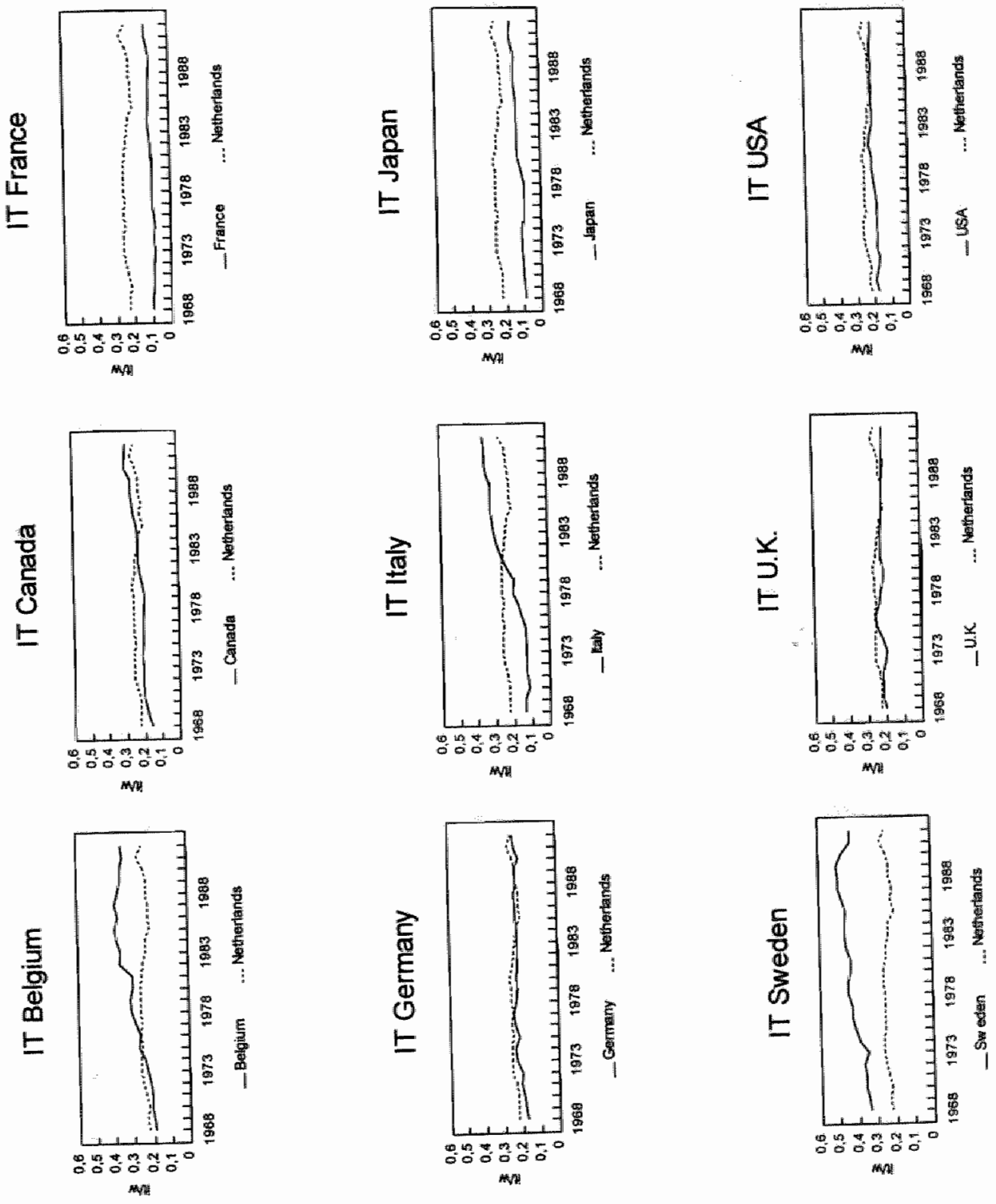
Appendix 6G

The development of employees' part of the wedge; the Netherlands vs $9 \mathrm{OECD}$ countries
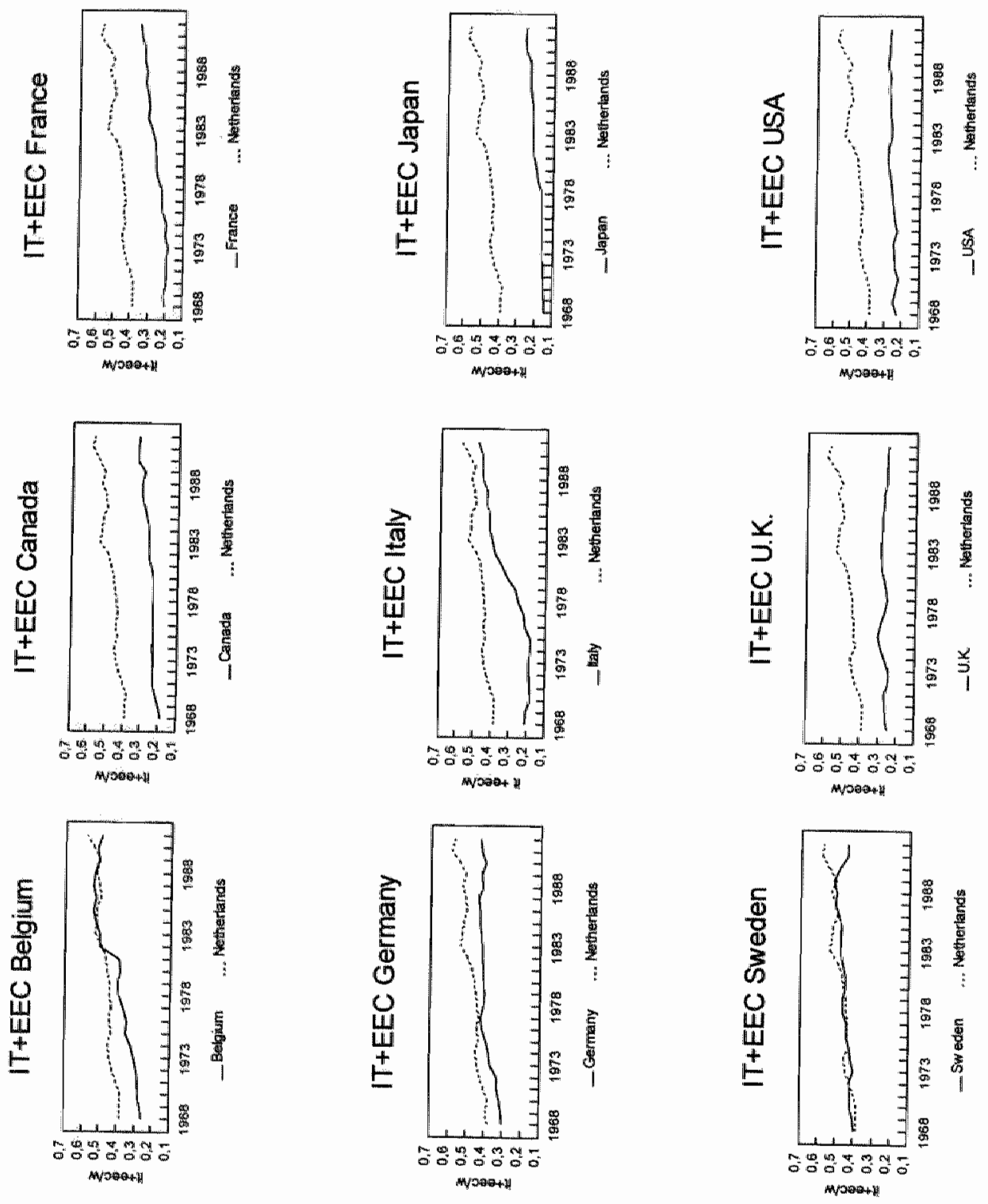


\section{Chapter 7}

\section{TAXES AND WAGES AND DALTON'S LAW I: THE MARKET CLEARING MODEL}

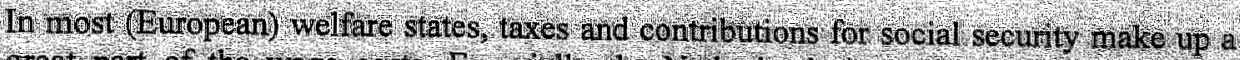
great part of the wage costs Espectaly the Netherlands is well-kingwh for that arge wedge and in the pre vious chapter one cowld conclude that the wedge in the Netherlands

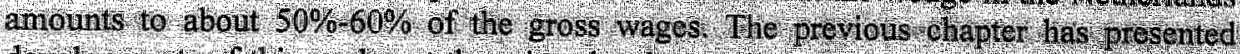
developments of this wedge at the niero level as well as time series for aggregate terat Further, the Netherlanis has been eompared with other OECD counthes. Whit nain question in this chapter deals with the effects of such taxes on the laboun market Wlow

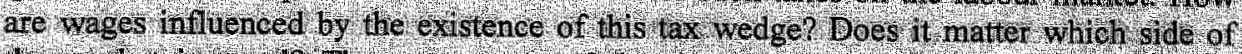
the market is waxed? These are some of the questions to be discussed. This chapten focuses on a market clearing nodel of the labour manket the next chap ter will and yse the sarie lend of questions in bargaining models.

\subsection{Introduction}

As could be seen in the previous chapter, the difference between the wage costs to be paid by the employer and the net wages that are received by the employees consists of taxes and contributions for social security and is called the wedge. This wedge is subject to numerous discussions in the Netherlands. The magnitude, the ratio between employers' and employees' contributions and the influence of a change in the wedge on wage developments are the most discussed topics. These can be summarized in two questions in particular:

1) What happens with price and quantity on a market when the wedge changes?

2) Do the results depend on which part (i.e. employers/employees) of the wedge is changed?

In this and in the next chapter, these questions are discussed. In this chapter the "basics" of the wedge are discussed and I. focus on market clearing models. In the next chapter these questions are discussed in a bargaining framework.

The aim of this chapter is to create a "benchmark case" so that the results of the incorporation of taxes in bargaining models (the next's chapters topic) can be compared. I will also elaborate on a famous theorem from public finance theory concerning the side of the market that is taxed: Dalton's Law. Note that I do not discuss general questions concerning taxation like the welfare burden of taxation.

In textbooks (Musgrave and Musgrave (1987), Stiglitz (1988)) and research papers (Keller (1980), Compaijen and Vijlbrief (1994)) Dalton's Law is often referred 
to. Mostly, Dalton's Law is discussed shortly and only with the help of a graph like the Figures 7.1 and 7.2 in this chapter, and not much attention is paid to the analysis behind Dalton's Law. This chapter differs, in that it extends this type of analysis by carefully analysing what Dalton's Law actually implies. Further, this chapter pays much attention to tax shifting under conditions of perfect competition and the question under what conditions tax shifting occurs. By working through a simple demand and supply model, the role of the elasticities of demand and supply is discussed. Note finally, that this chapter discusses partial analysis. Keller (1980) extends Dalton's Law for a general equilibrium approach.

The chapter is organized as follows. Section 7.2 gives an explanation of the "basics" about tax incidence and tax shifting. This allows to analyse various aspects of tax shifting. In section 7.3 I discuss Dalton's Law at length and I review some major implications of this theorem in section 7.4. Section 7.5 shortly discusses the relation between Dalton"s Law and tax equivalence. Finally, section 7.6 ends with concluding remarks.

\subsection{Tax incidence and tax shifting}

The introduction of taxes on a market causes a difference between the final prices paid by the buyers and the final prices received by the sellers of a good. This difference is also known as a wedge. The focus in this chapter is on the economic effects of this wedge and changes in it.

The effects of taxes on a market have been extensively analysed in public finance theory (e.g. Musgrave and Musgrave (1987); Stiglitz (1988)). An important result is that in discussing the effects of taxation one must distinguish between the legall liability for payment or legal burden (statutory incidence) and the actual economic burden (economic incidence) of a tax. The legal burden tells "who pays the money", while the economic burden is concerned with the question "who bears the cost of a tax. For example, sales taxes are levied on the seller of a good. Thus the introduction of such a tax seems to be a burden for the seller of a good. However, if the seller can increase his price exactly by the amount of the tax, the tax burden is actually borne by the buyer of the good. In this example the statutory incidence is on the seller of the good while the economic incidence falls on the buyer of this good.

If the final or economic incidence differs from the statutory incidence, shifting has taken place. According to Musgrave and Musgrave (1987):

"Determining the actual distribution of the tax burden (..) requires an analysis of the economic adjustment process, or the transmission of the 
burden from its impact point (the place of statutory incidence) to its final resting point (the place of econamic incidence). This process is generally referred to as "shifting"." (p. 251).

If a tax is imposed on a good, an adjustment process towards a new equilibrium starts. For example, if the tax is levied on the supply side of the market, suppliers will try to raise their supply price (price inclusive of taxes) thus shifting the burden of the tax on to sale prices. This type of shifting is called forward shifting. If, however, the tax is levied on the demand side, a decrease in demand can be expected, lowering the demand price (before-tax-price). This type of shifting is called backward shifting. ${ }^{1}$ In the labour market, taxes are levied on both sides of the market. Income taxes and employees" contributions to social security are taxes that are levied on the supply side of the labour market while payroll taxes or employers' contributions to social security are levied on the demand side of the market. Note that shifting can both be an intended or an unintended side-effect of tax policy. If the government levies an excise on spirits in order to discourage addiction, the intention is that the taxes are collected by the suppliers but borne by the demand side of the market. The supply side only serves as a convenient collection point for this kind of taxes.

It will be obvious that from the point of view of an economic analysis, the economic burden is more important than the legal burden. Hence, one may ask how the economic burden is determined. In this respect, an interesting conclusion from tax shifting analysis in the theory of public finance is known as Dalton's Law, which states that the final or economic burden of a tax does not depend on the statutory incidence but on the price elasticities of demand and supply. This theorem is proved and dealt with extensively in Dalton (1954), Keller (1980), Musgrave and Musgrave (1987) and Stiglitz (1988). A corollary of this theorem is that it is not relevant on which side of the market the tax is levied. I will deal with this theorem at length in section 7.3. First,

I Terminology with regard to backward shifting is not always clear. Some anthors (e.g. Stiglitz) suggest that only if a tax is borne by factors of production (while the tax is not levied on them), does backward sinifting occur. For example, suppose a tax is levied on suppliers on the goods market and suppose that supply is nearly inelastic, then suppliers bear the full burden of the tax. If as a result profits decrease, demand for labour dimümishes and consequently wages are lowered, then backward shifting takes place in this view. However, the disadwantage of this approach is that where forward shifting is defined within a partial equilibrium framework, backward shifting is defined in a semipartial framework: other markets are included into the analysis. In my view this is confusing. According to the approach used in this study, forward shifting occurs whenever the tax is levied on the supply side of the market, while backward shifting occurs when the tax is levied on the demand side of the market. 
the changes that the introduction of taxes cause when they are introduced on a market, will be carefully analysed, in particular two questions:

1) How is the economic burden of a tax determined?

2) What are the implications of a difference between the statutory and the economic burden of a tax?

So far one can conclude that shifting of taxes aims at transferring a tax burden from one agent to another. This results in a difference between the statutory and the economic burden of a tax. The question arises whether agents will succeed in reaching a favourable distribution of the economic burden of the tax. The analysis of tax shifting discusses this question.

\subsection{Theoretical framework of tax shifting on competitive markets}

I start the analysis by revealing some concepts that will be useful in analysing shifting processes. ${ }^{2}$ I first give a graphical analysis and continue with a more formal approach.

\section{A simple demand and supply schedule}

It is assumed that demand for labour (nd) is negatively and the supply curve of labour (ns) positively related to the wage rate. The case of a backward bending supply curve is excluded. It is further assumed that the labour market behaves as a perfect competitive market, which is always in equilibrium. The starting wage is denoted by $W^{*}$, which in this model in absence of taxes equals both the wage costs for the employer and the net wage for the employee. Figure 7.1 presents this market graphically.

Assume that labour income will be taxed and that employees do not suffer from tax illusion. Then they obeserve that, given the gross wages, net wages are lowered and consequently they will decrease labour supply. Thus the supply curve will shift to the left, cf. Figure 7.1A. The new supply curve is denoted by ns'. In the new equilibrium situation the wage rate has risen to $\mathrm{Wc}$, the new transaction price. This is the wage costs for the employer and at the same time this equals the gross wage for employees; their net wage is denoted by $\mathrm{Wn}$.

The amount of taxes equals [Wc-Wn]L, to be collected from the employees. However, this does not imply that the burden of this tax rests on the shoulders of the employees only. This is easily seen because wages have risen. As was argued before, the economic burden of a tax is important. This economic burden of the tax is defined as the difference between the price before and after taxes or a change in taxes, multi-

2 I will provide a rough sketch. For more detailed analyses I refer to standard textbooks in the field of public finance like Musgrave and Musgrave (1987) and Stiglitz (1988). Keller (1980) provides an extensive analysis of shifting within a general equilibrium framework with an application for the Netherlands. 
plied by the amount sold. ${ }^{3}$ Thus the burden for the employees equals $\left[\mathrm{W}^{*}-\mathrm{Wn}\right] \mathrm{L}$ and the burden for employers equals $\left[\mathrm{Wc}_{\mathrm{C}} \mathrm{W}^{*}\right] \mathrm{L}^{4}{ }^{4}$

Figure 7.1 The labour market and the influence of taxation

Figure 7.1A

Figure 7.1B

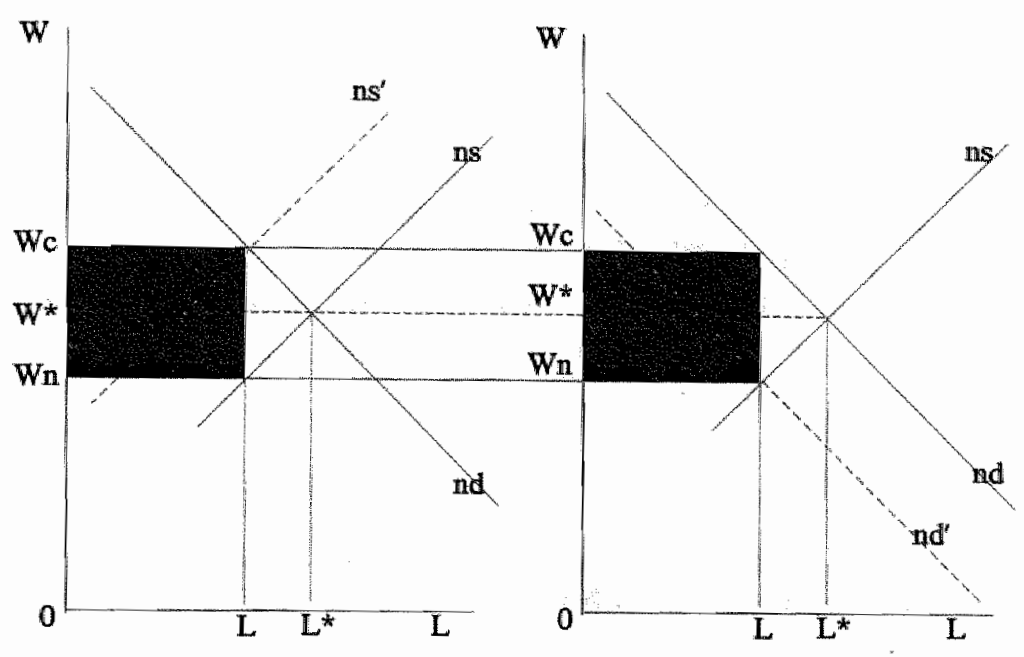

From Figure 7.1A I conclude that the distribution of the economic burden of the tax between sellers and buyers is equal to $\left[\mathrm{W}^{*}-\mathrm{Wn}_{\mathrm{n}}\right]\left[\mathrm{Wc}-\mathrm{W}^{*}\right]$. Note that this distribution differs from the distribution of the legal burden, since the legal burden for the employees equals (Wc-Wn)L and equals 0 for the employers.

This simple example shows that, if tax shifting occurs, the distribution of the economic burden of a tax differs from the distribution of the financial or the legal

3 By using this definition I neglect the excess burden of taxes. This excess burden is the welfare loss caused by a reduction in consumer surplus because the traded volume has been decreased.

4 Two notes. First, keep in mind that "burden" excludes the welfare burden. Second, Varian (1984) argues that this result is only a short run effect. In a long run equilibrium, prices equal minimum avarage cost. Hence a price decrease implies a loss for the supplier and will cause exit from the market untill the price equals the minimum average costs again. This implies that the demand side pays for the full tax in the long run. 
burden. If employees have to pay for the taxes but at the same time succeed in increasing their wages, part of the tax payments are taken from the employers. And the larger the wage increase at a prevailing tax rate, the lower the economic burden for the employees.

Next, assume that instead of labour income, the payroll of the firms will be taxed by the same percentage as in the case of income taxation. Initially, the labour demand curve remains the same, but, given the gross wage, if employers want to keep all their employees within the firm, the wage bill rises. Hence, firms decrease their demand for labour at each gross wage level and the result is a shift leftward of the demand curve. This is shown in Figure 7.1B. The gross wage now is equal to $\mathrm{Wn}$ and the wage costs equal Wc, as before. The figure shows that the statutory incidence for employers is equal to Wc - Wn. However, if the transaction price was still $W^{*}$, their wage costs would be higher than Wc. That is, the economic burden (Wc - W*)L is smaller than the statutory burden. Apparently employers have shifted part of their burden to the employees and as a result, the transaction price has decreased. Finally, note that the tax revenues are the same in both cases, as can be seen by the shaded area. The findings are summarized in Table 7.1.

Table 7.1 Economic and statutory burden

\begin{tabular}{|c|c|c|c|c|c|}
\hline & statutory & burden & economic & burden & note \\
\hline taxes on & employees & employers & employees & employers & \\
\hline $\begin{array}{l}\text { only employees } \\
\text { (7.1A) }\end{array}$ & $(\mathrm{W}-\mathrm{Wn}) \mathrm{L}$ & 0 & $\left(W^{*}-W n\right) L$ & $\left(W-W^{*}\right) L$ & $W=W_{c}$ \\
\hline $\begin{array}{l}\text { only employers } \\
\text { (7.1B) }\end{array}$ & 0 & $(W c-W) L$ & $\left(W^{*}=W\right) L$ & $\left(W_{c}-W^{*}\right) L$ & $\mathrm{~W}=\mathrm{Wn}_{\mathrm{n}}$ \\
\hline
\end{tabular}

Implicitly, an important theorem is derived. Although taxes are collected only from the employees in the first example, it can easily be seen that the distribution of the economic burden of the tax remains the same as in the case where only the employers are taxed. Consequently, since the economic burden counts, it does not matter, in this example of competitive markets, which side of the market is taxed. Note that the wage costs and the net wages are the same in Figures $7.1 \mathrm{~A}$ and $7.1 \mathrm{~B}$, but that the gross wages differ.

In Figure 7.1A the gross wages increase, while in Figure 7.1B they decrease. But this different "behaviour" of the gross wage does not imply that therefore the 
burden of a tax differs too, i.e. that wage costs and net wages also show a different behaviour.

In order to define the concepts more precisely, I use the following framework. Let the gross wage be equal to $W .^{5}$ Then the wage costs paid by employers, W/ $c_{\text {, will }}$ include payroll taxes and employers' contributions for social security with a share (E 1) of gross wages; hence $W_{c}=E . W$. And the net wages received by employees, $\mathrm{Wn}$ will be net of income taxes and employees' contributions for social security, with a share of $(1-\Delta)$ of gross wages; hence $W n=\Delta . W$. One can also look at the wedge, which can be defined as the ratio between wage costs and net wages: this is equal to $\mathrm{E} / \Delta^{6}{ }^{6}$ Finally, in order to introduce the last concept, let the equilibrium wage in absence of taxes be $W^{*} .{ }^{7}$ Related to the gross wage one then defines $W^{*}=\Gamma . W$, with $\Gamma=1$ at the start of the analysis.

For analytical purposes the analysis will be presented in logarithms. These will be expressed as lower case variables. ${ }^{8}$ Then I have now defined, given that the equilibrium wage in the absence of taxes is denoted by $w^{*}$ :

$\begin{array}{lll}\text { gross wage } & w=w *-\gamma & \gamma \leq \geq 0 \\ \text { wage costs } & w c=w+\epsilon & \epsilon \geq 0 \\ \text { net wage } & w n=w+\delta & \delta \leq 0\end{array}$

In order to look at the division of the wedge according to the statutory burden, one simply has to look at the statutory tax rates. As has been argued, tax shifting occurs when the division of the wedge according to the economic burden is different. This can be illustrated in Figure 7.2, which combines figures 7.1A and 7.1B and which for analytical reasons assumes $\log$-linear supply and demand curves of labour in absence of taxes, $n s$ and $n d$, respectively. Point $\mathrm{A}$ is the equilibrium without taxes. The equilibrium wage then is equal to $w^{*}$. Introduction of employees' taxes shifts the supply curve to the left, to ns". And when employers' taxes and contributions are intro-

5 Note that the gross wage is in fact the new equilibrium wage after levying taxes.

6 This definition is chosen for analytical reasons. In the previous chapter I have used the more standard definition of $\mathrm{E}-\Delta$.

7 For simplicity reasons, $I$ assume that the starting point of the analysis is a situation where no taxes are levied.

8 In the case of greek symbols $\varepsilon=\ln E, \delta=\ln \Delta$ and $\gamma=\ln \Gamma$. 
duced, the labour demand curve also shifts to the left, to nd". This has a decreasing impact on the gross wage. The new equilibrium level is represented by point $\mathrm{E}$.

Figure 7.2 Taxes and the labour market

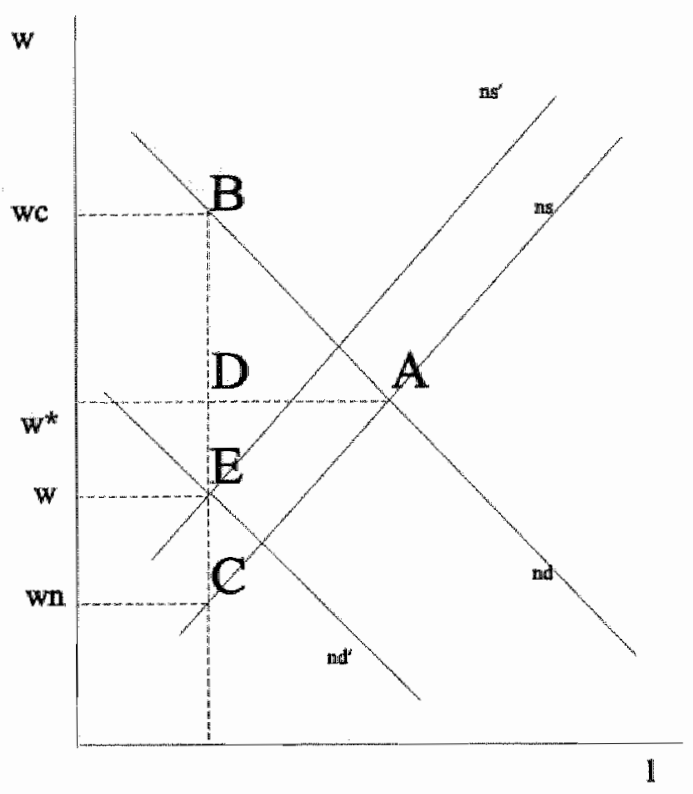

From Figure 7.2 one can easily see that in logarithms the statutory incidence for employers, $\mathrm{BE}$, is equal to $w c-w=\varepsilon$ and that for employees, $E C$, equals $w-w n=-$ $\delta$. Together they constitute the total wedge, $\mathrm{BC}$, or $\varepsilon-\delta$. The distribution of the economic incidence differs because the transaction price (gross wages) has decreased. This decreases the employers' burden and increases the employees' burden. Hence, to measure the economic incidence, one must correct the statutory burden for the change in the transaction price. It will be clear from Figure 7.2 that after the introduction of the taxes, the transaction price has decreased with $\mathrm{DE}$, from $w^{*}$ to $w$. Hence, one can derive that the economic burden for the employers, $\mathrm{BD}$, equals $(\mathrm{wc}-\mathrm{w})-\left(\mathrm{w}^{*}-\mathrm{w}\right)=\varepsilon$ $-\gamma$. The economic burden for employees, DC, then is $(w-w n)+\left(w^{*}-w\right)=\gamma-\delta$. In this context one should realize that the core of the concept of economic burden is the change in the transaction price that occurs after the imposition of the tax. If the transaction price does not change, the economic burden is equal to the statutory burden. Consequently, in the measurement of the economic burden, one has to take into account this change in the transaction price. 
Table 7.2 Tax burden and distribution of tax change

\begin{tabular}{|c|c|c|}
\hline & Statutory & Economic $\left(w^{*}-w=\gamma\right)$ \\
\hline Employers & $w c-w=\epsilon$ & $w c-w *=\epsilon-\gamma$ \\
\hline Employees & $w-w n=-\delta$ & $w *-w n=\gamma-\delta$ \\
\hline Total & $w c-w n=\epsilon-\delta$ & $w c-w n=\epsilon-\delta$ \\
\hline $\begin{array}{l}\text { Distribution of } \\
\text { tax change }\end{array}$ & $\frac{w c-w}{w-w n}=-\frac{\epsilon}{\delta}$ & $\frac{w c-w *}{w *-w n}=-\frac{\epsilon-\gamma}{\delta-\gamma}$ \\
\hline
\end{tabular}

Both ways of dividing the total burden are summarized in Table 7.2. It is clear that the decomposition of the wedge according to the statutory burden is different from that according to the economic burden when $\gamma$ is not equal to zero, i.e. when the gross wage differs from the equilibrium wage before taxes. When $\gamma$ is positive, as is the case in Figure 7.2, employers have succeeded in shifting part of their burden towards the employees. This is called backward shifting, since in this case the demand side of the market dominates. In the opposite case the supply side will dominate and forward shifting takes place: then $\gamma$ is negative. Thus $\gamma$ is a parameter which indicates whether shifting takes place and in which direction.

\subsection{Dalton's Law}

Two major questions are important in the analysis of tax shifting. First, under what conditions does tax shifting occur, and second, does it matter whether taxes are levied on the demand side or on the supply side of the market concerning the shifting process?

The answer to these questions from the theory of public finance is that if a tax is levied on a perfect competitive market, the final or economic burden of a tax does 
not depend on the statutory incidence: hence it is not relevant on which side of the market the tax is levied - I call this the irrelevance theorem. This theorem is proved and dealt with extensively in Dalton (1954), Keller (1980), Musgrave and Musgrave (1987), and Stiglitz (1988) - it is also known as Dalton's Law. ${ }^{9}$ A corollary of Dalton's Law is that the final or economic burden of a tax depends on the price elasticities of demand and supply.

Tax shifting usually is analysed by looking at the effects of marginal changes in taxes and consequently Dalton's Law implicitly refers to changes in the variables (see also Keller (1980); Musgrave and Musgrave (1987)). Since the distribution of the economic burden can be represented by $\left(w c-w^{*}\right) /\left(w^{*}-w n\right)$ and that of the statutory burden by $(w c-w) /(w-w n)$ - see also Table 7.2 - Dalton's Law implies:

$$
\frac{d[(w c-w *) /(w *-w n)]}{d[(w c-w) /(w-w n)]}=0
$$

that is, the change in the distribution of the economic burden is independent of that of the statutory burden. I call this the independence theorem. After some manipulation it can be shown that this implies that the elasticity of wage costs with respect to net wages is independent of the wedge. ${ }^{10}$ Or that the elasticities of both wage costs and net wage with respect to the wedge are independent of the wedge. I will concentrate in the further analysis on the elasticity of wage costs with respect to the wedge, which is defined by $\mathrm{d}(\mathrm{wc}) / \mathrm{d}(\varepsilon-\delta)$ - its independence also implies independence of the elasticity of the net wage. Dalton's Law then requires: ${ }^{1.1}$

$$
\frac{d^{2} w c}{d(\epsilon-8)^{2}}=0
$$

9 Note that although each well-known textbook in public finance discusses Dalton's Law, a reference to the original work by Dalton can hardly be found (see e.g. Musgrave and Musgrave (1987) and Stiglitz (1988)). That is why one will search in vain for the expression "Dalton's Law" in such textbooks. It seems that in research papers more credit is given to Dalton's work (see for example Keller (1980) and Compaijen and Vijlbrief (1994))

10 Since the variables are in logarithms, the elasticity of wage costs with respect to net wages is given by dwo/dwn.

11 Note that Dalton's Law does not require that the elasticity equals 0 , but that the elasticity is independent of the wedge. Therefore I differentiate this elasticity towards the wedge. 


\section{A simple model}

Dalton's Law can be illustrated for a labour market with perfect competition. I define a labour supply relation where labour supply $\left(\mathrm{L}^{\mathrm{s}}\right)$ is positively related to net wages ( $\triangle . W$ ). Labour demand $\left(L^{d}\right)$ is negatively related to wage costs (E.W). For simplicity $I$ assume constant elasticities of supply and demand, $\alpha$ and $\beta$ respectively. Then the following model results:

$$
\begin{gathered}
L^{s}=A(\Delta . W)^{\alpha} \quad \alpha>0 \\
L^{d}=B(E . W)^{\beta} \quad \beta<0 \\
L^{s}=L^{d}
\end{gathered}
$$

with A, B constant. The solution for wage costs and employment is: ${ }^{12}$

$$
\begin{gathered}
w c=w *+[\alpha /(\alpha-\beta)] \cdot(\epsilon-\delta) \\
l=l *+[\alpha \beta /(\alpha-\beta)] \cdot(\epsilon-\delta)
\end{gathered}
$$

From (7.7) it follows that the elasticity of the wage costs with respect to the wedge is equal to $\alpha /(\alpha-\beta)$, hence it is independent of the wedge. Thus equation (7.3) is satisfied and Dalton's Law holds. Moreover, it can easily be shown that the distribution of the economic burden, $\left(w c-w^{*}\right) /\left(w^{*}-w n\right)$, is equal to the ratio of the elasticities, $\alpha^{*} / \beta^{13}$ This is consistent with the corollary to Dalton's Law mentioned above.

In section $7.2 \mathbb{I}$ introduced $\gamma$, a parameter that indicates whether shifting has occurred and in which direction. $\gamma$ is calculated as the difference between the gross wage before the tax change ( $w^{*}$ ) minus the gross wage after the tax change (w). Hence, in this model the shifting parameter is given by:

12. From this simple model one can derive the level of tax free wages ( $\left.W^{*}\right)$ and tax-free employment $\left(L^{*}\right)$ to be $W^{*}=(B / A)^{1 /(\alpha-\beta)}$ and $L^{*}=A^{-B /(\alpha-\beta)} \cdot B^{\alpha /(\alpha-\beta)}$, respectively.

13 Note that from $(7.1)$ and $(7.7)$ derive $w n=w^{*}+(\beta /(\alpha-\beta))[\varepsilon-\delta]$. 


$$
\gamma=-[\beta /(\alpha-\beta)] \cdot \epsilon+[\alpha /(\alpha-\beta)] . \delta
$$

For $\beta, \alpha \neq 0$, shifting occurs in this model. Note that the direction of shifting depends on $\varepsilon$ and $\delta$, but from the previous section it is known that this does not imply that it is relevant which side of the market is taxed. From equation (7.9) one sees that employers will shift more of their burden on employees $(\gamma>0)$ as long as the increase in their burden does not exceed the increase in that of employees by a factor $\alpha / \beta$. That is as long as $\varepsilon / \delta<\alpha / \beta$ holds. Thus the ratio of elasticities of demand and supply plays an important role in the shifting process. This can also be seen from Figure 7.2 where it cannot be said beforehand whether the gross wage corresponding to the new equilibrium level $\mathrm{E}$ exceeds the original equilibrium level $\mathrm{A}$ or not. It is obvious from the figure that this depends on the slopes of the curves, thus the elasticities of demand and supply are important in the determination of shifting.

\subsection{Implications of Dalton's Law}

As was derived and concluded, with respect to the distributional aspects of the economic burden of the tax one can derive "an interesting rule - namely that the economic burden of a tax is divided between buyer and seller as the ratio of elasticity of supply to elasticity of demand in the relevant range of the demand and supply schedules" as Musgrave and Musgrave (1987) have denoted this irrelevance theorem.

In order to specify the implications of Dalton's Law more precisely, I analyse this law with the help of the following propositions: ${ }^{14}$

1. According to this law, the final or economic burden of a tax depends on the price elasticities of demand and supply.

In terms of equation (7.1), the change in $\gamma$ is such that the effects of changes in $\varepsilon$ and $\delta$ are neutralized: the change in the gross wage relative to the equilibrium wage in absence of taxes compensates any change in the statutory burdens. I have derived before that the economic burden of a tax is distributed according to $\alpha / \beta$.

2. The Irrelevance Theorem: a corollary of proposition 1 is that, from the point of view of the distribution of the economic burden, it is not relevant on which side of the market the tax is levied.

14 Note that it is assumed that taxes are levied on perfect competitive markets. 
This proposition says that for given price elasticities of demand and supply, the distribution of the economic burden of the tax is completely determined and consequently independent of the side of the market that pays for the tax. I refer to Figures 7.1 and 7.2 for a graphical illustration of this result.

3. The Independence Theorem: the distribution of the economic burden of the tax is independent of the way the collection of taxes is organized.

This theorem is in fact an alternative for theorem 2. Given the existence of Dalton's Law, one can conclude that it does not matter which side of the market is taxed or that the distribution of the economic burden is independent of the distribution of the statutory burden. I have demonstrated and discussed this proposition extensively before. Note that this theorem implies that tax shifting is inherent to market behaviour.

4. With respect to the effect on the quantity that is traded on market, proposition 3 holds too.

Proposition 4 discusses the employment effects of a tax on the labour market. These are not discussed explicitly before, but from Figures 7.1 and 7.2 it will be clear that the change in the level of employment is independent of the side of the market that is taxed. In (7.8) I have derived the solution for employment and it follows that an increase in $\varepsilon$ or a decrease in $\delta$ have exactly the same negative effect on employment.

Finally, note that Dalton's Law has been discussed in a partial equilibrium framework. However, Dalton's Law has an interesting implication and Keller (1980) comments on this result:

"Only net prices matter. Therefore the burden is distributed independently of who is paying the tax. This result, which of course draws heavily upon the assumption of absence of tax illusion, holds not only in partial analysis but also in more general contexts".

Note that the net prices from Keller equal the net wages and the wage costs according to my terminology. 


\subsection{Dalton's Law and tax equivalence ${ }^{15}$}

Closely related to the question how the burden of a tax is distributed is the question whether tax regimes are equivalent or not. Two tax systems are equivalent when they both result in the same outcome with respect to total tax revenue, output and prices (Musgrave and Musgrave, 1987). Applied to the labour market, this means that taxing via employers' contributions is equivalent to taxing via employees' contributions when the resulting employment, net wages and wage costs are the same in both regimes. Consequently, total tax revenue is the same in equivalent tax systems. It can easily be verified that if tax regimes are equivalent, Dalton's Law holds: the distribution of the economic burden of a tax is independent of the statutory burden. Moreover, it is irrelevant which side of the market is taxed.

It can easily be shown that tax systems are equivalent when the ratio $\delta / \varepsilon$ is constant. Suppose one wants to compare the effects of two different tax systems. ${ }^{16}$ Then the following relations are relevant:

$$
\begin{aligned}
& w n=\delta w \\
& w c=\epsilon w
\end{aligned}
$$

and

$$
\begin{aligned}
& w n^{\prime}=\delta^{\prime} w^{\prime} \\
& w c^{\prime}=\epsilon^{\prime} w^{\prime}
\end{aligned}
$$

(7.10) defines the relation between net wages, gross wages and wage costs for tax system 1 and (7.11) defines them for tax system 2. If these systems are equivalent, then the following relations must hold:

$$
\begin{aligned}
w n & =\delta w=\delta^{\prime} w^{\prime}=w n^{\prime} \\
w c & =\epsilon w=\epsilon^{\prime} w^{\prime}=w c^{\prime}
\end{aligned}
$$

and it follows $w n / w c=\delta / \varepsilon$ and $w^{\prime \prime} / w_{c}^{\prime}=\delta^{\prime} / \varepsilon^{\prime}$. Since $w n=w n^{\prime}$ and $w c=w c^{\prime}$ in an equivalent tax system, a necessary condition for equivalence is $\delta / \varepsilon=\delta^{\prime} / \varepsilon^{\prime}$

15 This section relies heavily on comments by Lex Borghans on an earlier draft. 
Note finally that Dalton's Law is much broader than the concept of tax equivalence. In Dalton's Law, the ratio $\delta / \varepsilon$ plays no role. Dalton's Law simply states that the economic burden is independent of the statutory burden without any restriction on the ratio $\delta / \varepsilon$.

\subsection{Conclusions}

The analysis of tax incidence allows to draw four conclusions. ${ }^{17}$ First, only if at least one market party bases its decisions on net prices, will the economic burden of the tax differ from the legal burden. In other words, tax shifting then occurs. Second, in case of tax shifting a new market equilibrium will be achieved with higher prices and a lower trading volume than before the tax (increase). Third, tax shifting only influences the distribution of the economic burden of a tax; the distribution of the legal burden is of course not influenced. Fourth, the distribution of the economic burden of a tax depends on the price elasticities of demand and supply. The more an economic agent can adjust after a tax or a change in the magnitude of the tax has been levied, the less his (relative) economic burden is. This last conclusion implies that it does not matter which side of the market is taxed. In a perfect competitive labour market an increase in employees' premiums/taxes has exactly the same effect as an increase in employers' contributions. I call this the irrelevance theorem. To summarize, and recalling the questions in section 7.1, an increase in the wedge causes an increase in wage costs and a decrease in the net wages. Moreover, employment decreases. These results are independent of which part of the wedge is changed. The development of the gross wages depends on which side of the market is taxed. Of course, an interesting question appears: what happens if the labour market is not competitive? I return to this question in the next chapter.

17 These conclusions hold if price elasticities differ from 0. 


\section{TAXES AND WAGES AND DALTON'S LAW II: WAGE BARGAINING MODELS*}

The previous chapter discussed Dalton's Law, which basieally states that it does not matter which side of the market is taxed. This law has been analysed in a well functioning labour market ramework. This means filextbility of prices and no wage bargaining. However, as chapter 2 conchided, he Dutch labour narket is chatraeterized by wage tuargaining. This chapter then analyses whether. Balton's Law still holds in a bargaining framework. Whereafter empinical exidence, is discussed conoering tax shifing in wage bargain nodels, bolh for the Vetherlands arde for other coinithies.

\subsection{Introduction}

Like in the previous chapter, the aim of this chapter is to analyse whether the legal distribution of taxes on wages between employers and employees matters in measuring the economic burden of a tax: does it matter which side of the labour market is taxed? According to Dalton's law it does not: the economic burden of a tax is independent of the legal burden that is imposed on both parties. This result was derived and analysed using simple demand and supply analysis, where prices clear the market and a new equilibrium is restored after the distortion caused by a tax or a change in the tax. However, the situation on the labour market differs from such a type of market. The wage-setting process in most countries is characterized by a bargaining process where wage contracts are concluded. The terms of the various contracts vary, but are fixed for at least one year. Thus prices on the labour market do not adjust in line with the model that underlies the work of Daiton. Moreover, the legal distribution of the various taxes and contributions for social security is heavily discussed in actual life. Following Dalton's law, one could ask whether such a discussion is useful. ${ }^{1}$

1 As Varian (1984) concludes in discussing the impact of taxes on a perfect competitive market,it does not matter which side of the market is taxed, "a fact that is apparently not understood by most legislators"t (p. 90). 
In this context, Blinder (1988) has stated the problem clearly:

'(..) consider what may be the most basic theorem of public finance: the irrelevance of the side of the market on which a tax is levied. We all have had fun explaining to our beginning students why it doesn't matter whether the payroll tax is levied on employers or employees. Then why (.) do Congress, labor and management all think the decision so momentous? Sheer lack of understanding? (..). I submit that part of the answer is (..) that we economists insist on thinking long-run equilibrium while everyone else lives in short-run disequilibrium. The truth of the matter is that the incidence of the payroll tax may differ dramatically in the short and long runs.' (p. 12).

Blinder points out that, if prices are sticky, the economic burden equals the legal burden and therefore tax-shifting is not possible. Consequently, it matters on which side of the market the tax is levied. However, one can argue that this is only a shortrun problem: in the long run, whenever it is reached, it still does not matter on which side of the market the tax is levied. Blinder's answer is based on wages that are determined on a competitive labour market. However, in Western economies wages are set in bargaining processes between employers and employees. Does this change the conclusions of the market model?

In this chapter, I want to extend the answer that has been given by Blinder. I will discuss the effects of taxation in models of wage determination that differ from the market model. The aim is to analyse whether the legal distribution of taxes does matter and consequently whether the related discussions do make sense. For that purpose I start with a discussion of the wage bargaining model that was developed by Knoester and Van der Windt (1987). Thereafter I analyse the effects of taxes in a right-to-manage model.

The chapter is organized as follows. In the next section the question is analysed whether it does matter which side of the market is taxed. Next, in section 8.3 empirical research with respect to tax shifting in the Netherlands is reviewed and some estimation results are presented. The perspective is widened in section 8.4, where I review empirical research for other $\mathrm{OECD}$ countries. The final section provides the conclusions. 


\subsection{Wage bargaining}

In the previous chapter Dalton's Law was discussed and I showed that it holds when prices clear the market instantaneously. An interesting question then is whether Dalton's Law also holds in a situation when prices are bargained upon. For that reason I look at two models of wage bargaining. These models are chosen because they have often been used in empirical research concerning the role of taxes in wage formation. It will appear that Dalton's Law then only holds under very specific assumptions.

\subsubsection{Wage bargaining: a simple model}

An early wage bargaining model, which has been applied to the Netherlands, can be found in Brandsma and Van der Windt (1983) and Knoester and Van der Windt (1987). In that model it is assumed that wages result from bargaining about wage claims of employees and wage offers of employers. Wage claims ( $W^{c l}$ is the gross wage claim in real terms) from employees result from the notion that the labour share in national income (W.L/Y) should at least be equal to $\phi$. Moreover, employees calculate in terms of net wages. Hence the real wage claim is:

$$
W^{c l}=(1 / \Delta) \phi Y / L \quad 0 \leq \phi \leq 1
$$

where, as before, $\Delta$ equals the retention ratio. Wage offers ( $W^{\circ}$ is the gross wage offer) from employers result from profit maximizing behaviour, given a CES production structure. Employers take wage costs into account in the bargaining process. Hence, the wage offer is:

$$
W^{o}=(1 / E) k \cdot[Y / L]^{1 / o} \quad \sigma<1
$$

where $\mathrm{k}$ is a constant and $\sigma$ is the elasticity of substitution: the latter is assumed to be smaller than unity. Further $\mathrm{E}$ equals (1+payroll taxes).

An important assumption of the model is that employers set employment before the wage bargaining process starts. Hence wage offers and wage claims are made while employment is given. The bargaining process results in a agreement about a transactions price which is the geometric average of wage offers and wage claims, with weights $\psi$ and $(1-\psi)$ representing the bargaining power of employers and employees, respectively. The higher $\psi$ is, the higher the bargaining power of employers. It is assumed that the transactions price is the gross wages. One can write this as follows: 


$$
W=\left(W^{c k}\right)^{1-\psi} \cdot\left(W^{9}\right)^{\psi} \quad 0 \leq \Psi \leq 1
$$

It is assumed that in the next period employment is adjusted to the demand for labour consistent with the current new wage rate. Then new wage claims and offers result.

Solving equations (8.1) - (8.3), and taking logarithms, yields for wage costs:

$$
w c=w *+(1-\psi) \cdot(\epsilon-\delta)
$$

with the lower case variables being the logarithms $\left(w^{*}=\ln W^{*} ; \varepsilon=\ln E, \delta=\ln \Delta\right.$ ). In (8.4) the wage cost are split in a part that exists in absence of taxes ( $\left.w^{*}\right)$ and a part that is due to the existence of taxes $((1-\psi) .(\varepsilon-\delta)) .{ }^{2}$ One can now analyze the effects of employees' taxes and of employers' contributions. From equation (8.4) it follows that both an increase in employees' taxes and an increase in employers' contributions have a positive effect on wage costs. Note the important role of $\psi$, the bargaining power. If employers have all bargaining power $(\psi=1)$, then wage costs are not affected either by employers' or by employees' taxes. This is close to the intuition since in this case there will be no forward shifting and full backward shifting, implying that the tax burden is borne by the employees. Further, Dalton's Law holds in this model too: from equation (8.4) one sees that equation (7.3) is satisfied because there is no relation between the bargaining power and the wedge. Hence it does not matter which side of the market is taxed. This can also be seen from the fact that the distribution of the economic burden, which is equal to the ratio $(1-\psi) / \psi$, is independent of $\delta$ and $\varepsilon$.

In the previous chapter, a shifting parameter, $\gamma$, was defined to express the net result of a change in employers' and employees' contributions and taxes. This parameter can be derived from equation (8.4):

$$
\gamma=\psi \cdot \epsilon+(1-\psi) . \delta
$$

Recall that if $y>0$, backward shifting occurs. From equation (8.5) one sees that this condition holds if $\varepsilon \delta>-[(l-\psi) / \psi \psi$. Thus the bargaining power plays an important role in the shifting process. It can be concluded that in such a model set-up, there is no relation between the change in the wedge and the bargaining power. In this model the bargaining power basically plays the role of the elasticities. Hence it does not matter which side of the market is taxed.

2 Hence, $W^{*}$ can be found by sloving equations (8.1) - (8.3) and setting $\Delta=E=1$. The result equals the wage in absence of taxes. 


\subsubsection{A right-to-manage model of wage bargaining}

\section{The model set-up}

The development of employment is unclear in the previous model. It is a model of wage determination, without explicitly paying attention to employment. I therefore develop a bargaining model, somewhat similar to Knoester et al, in which employment is not assumed to be constant but is determined from profit maximization. Moreover, a right-to-manage structure is assumed; that is employers set employment after wage bargaining has taken place, of chapter 3. As before, the Nash bargaining solution is used as the solution concept.

Employers aim at maximal profits. However, there is a minimum acceptable level of real profits, which is a fraction $\chi$ of real income. Hence, the maximum real wage offer $\left(W^{\text {mo }}\right)$ is

$$
W^{m o}=(1-\chi) Y / L \quad 0 \leq \chi \leq 1
$$

and it follows that the minimum acceptable level of real profits equals $\mathrm{Y}-(1-\chi) \mathrm{Y}=\chi \mathrm{Y}$. This minimum acceptable level of real profits constitutes a threatpoint in the bargaining process over wages.

Employees are assumed to aim at a maximal wage sum. Moreover, they also have a threatpoint in the bargaining process, which results from the notion that the labour share in national income should at least be equal to $\phi$. Hence the minimum acceptable real wage $\left(\mathrm{W}^{\text {minin }}\right)$ is:

$$
W^{\text {min }}=\phi Y / L \quad 0 \leq \phi \leq 1
$$

It is assumed that the threatpoints are consistent, i.e. $\chi+\phi \leq 1$. However, since the focus is on the role of taxes, one must first incorporate taxes in this set-up. Therefore it is assumed that employers and unions strive after maximization of the difference between after tax income and the threatpoint income as defined in (8.6) and (8.7). ${ }^{3}$ Further, note that as in the previous model, bargaining is about gross wages, i.e. in this model about a gross wage sum.

3. A simpler case is the two-stage case: first, in the bargaining set-up one abstracts from taxes. After the solution is calculated, one concludes that basically the net wage has been calculated. Hence since net wages plus the wedge add up to wage costs, in the second stage wage costs are "derived" by adding up taxes to the solution that was found in the first stage. This approach was followed, for example. by Lever (1993). Apart from the differences in the set-up, $(8.10)$ changes $u w_{c}=w^{*}+((\mathrm{U}-$ $\left.\left.\ddot{u}^{*}\right) /(1-\sigma)\right)+\varepsilon-\delta$. The problem with this approach is, however, that taxes do not play any role in the maximization process and this seems unrealistic. 
Hence, wage bargaining aims to solve the following problem (see chapter 3 and in particular eq. 3.4 for the basic setup of the right-to-manage model):

$$
\max _{W} N(W, L)=\{(1-\chi) . Y-E \cdot W \cdot L\}^{\psi} \cdot\{\Delta \cdot W \cdot L-\phi \cdot Y\}^{1-\psi} \quad 0 \leq \Psi \leq 1
$$

$$
\begin{aligned}
\text { S.T. } Y(L) / L=k .(E . W)^{\circ} \quad \sigma<1 \\
Y \geq E . W . L \geq \chi Y \\
Y \geq \Delta W . L \geq \phi Y
\end{aligned}
$$

In equation (8.8), the Nash maximand, the parameter $\psi$ indicates the bargaining power: a higher $\psi$ represents more employers' power. For employers, the threatpoint implies that they strive after maximization of "surplus" profit, i.e. the profit that is reached above a certain minimum level, which is reached when the maximum wage offer must be paid (hence their utility function equals (Y - E.W.L) $-(Y-(1-\chi) Y)$ and recall that the threatpoint equals $(Y-(1-\chi) Y=\chi Y)$. The variables $\chi Y$ and $\phi Y$ (minimum acceptable wage sum) are the threatpoints of employers and employees, respectively. ${ }^{4}$ Equation (8.9) is the demand function for labour, derived from a CES function $Y(L)$, with an elasticity of substitution $\sigma<1$ and which poses a constraint to the maximization process.

The solution of the model

Solution of the Nash maximand results in wage costs given by:

$$
w c=w *+(\ddot{0}-\ddot{u} *) /(1-\sigma)
$$

where $\ddot{u}=\ln \left[1-\sigma \cdot L \cdot N_{L} / W \cdot N_{W}\right]$ and $\ddot{u}^{*}=\ln \left[I-\sigma . L . N^{*}{ }_{L} / W \cdot N^{*}{ }_{W}\right]$; and as before (see footnote 2), an asterix refers to the situation in absence of taxes. ${ }^{5}$

4 Note that $(1-\chi) Y$ thus equals the share of production that is left for wages and other income, once a minimum profit level is reached.

5 The wage $w^{*}$ is given by $w^{*}=\left(\ln k+v^{*}\right) /(1-\sigma)$ and $w c=(n k+v) /(1-\sigma)$ holds. The symbolls $N_{L}$ and $N_{W}$ refer to the partial derivatives of equation (8.8) with respect to $L$ and $W$, respectively. These are still functions of $W$. 
Actually the solution as presented in equation (8.10) holds for any specification of the function $N(W, L)$, and hence can be applied to many more bargaining situations than the one sketched here. As one can see from equation (8.10), the impact of the wedge, if any, results from its impact on the elasticities of the target function, $N(W, L)$. When one confines to the specification in equation (8.8) one finds that a further elaboration of the terms $\ddot{u}$ and $\ddot{u}^{*}$ leads to a rather complicated expression. However, this is mainly due to the inclusion of threat points. Therefore I start the analysis of the influence of taxes in the absence of threatpoints.

\section{i) the case without threatpoints}

If the model without incorporating the threatpoints is solved ${ }^{6}$, one finds

$$
w c=w *=\frac{1}{1-\sigma} \ln [k \cdot(1-\sigma) \cdot(1-\psi)]
$$

hence $w c=w^{*}$. That is, irrespective of bargaining power, wage costs will always equal the wage that would prevail without taxes: full backward shifting takes place and there is no forward shifting. To explain this result Figure 8.1. is used. The demand curve for labour nd is presented as well as the preferences of the workers that are indicated by indifference curves like $I 1, I 2$ and 13 in the figure - consistent with the goal of a net wage sum $\Delta$.W.L. ${ }^{7}$

This result implies that when employers have full bargaining power, $\psi=1$, employers will shift all taxes backwards towards the employees, hence $w c=w^{*}$ and $w n=w^{*}-\varepsilon+\delta$. Assume that for some reason employers choose point $C$ when they have full bargaining power - hence employment is at 11 and the wage rate is $w 1$. When taxes are levied on employers, the demand curve for labour shifts towards nd". When employers have full bargaining power, they will decrease the wages towards w0 and maintain both employment and wage costs at point $\mathrm{C}$.

6 Note that the Nash maximand then equals (the constraint remains the same)

$$
\begin{aligned}
& \max N(W, L)=\{Y-\mathrm{E} . W . L\}^{\psi} \cdot\{\Delta . W . L\}^{1-\psi} \\
& \text { S.T. } Y-\text { E. } W . L \geq 0 \\
& \Delta . W . L \leq Y
\end{aligned}
$$

7 Basically this figure is the same as figure 3.3. The assumption that workers strive after a real wage sum implies that in terms of logarithms the indifference curves are straight lines. For, according to equation (8.8) and leaving out the threatpoints, union utility (u) equals $u=\ln (\Delta W L)$ and then the slope of the indifference curve equals -1 . The point is that the slope is independent of $\delta$. The concavity of the demand function for labour is due to the property of $o<1$ - ef. equation (8.2). 
The reason why this result also should hold when employees have full bargaining power, $\psi=0$, is less intuitive. Note that in the case of employees having full bargaining power, there is a monopoly model. Since unions aim at a maximal wage sum, they will choose, in absence of taxes, point A, with wages w2 and employment 12. When taxes are levied on employees, one might expect that employees shift these forward towards employers when they have full bargaining power, and hence an increase in wage costs will be the result. However, one should realize that given the demand curve for labour of the employers, such an increase in wage costs always will be accompanied by lower employment and a smaller wage sum (note that the assumption that $\sigma<1$ implies that the elasticity of employment with respect to wages $>1)^{8}$

Figure 8.1 Taxes and the right-to-manage model

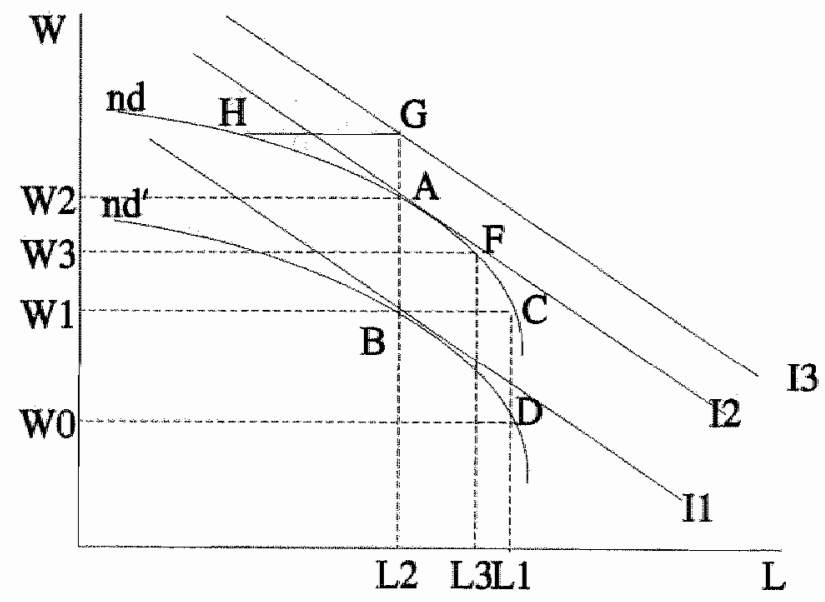

In Figure 8.1, if unions increase the wages from $A$ to $G$, employment will be set at $H$ and unions' utility will decrease. Hence employees will not prefer the situation with the lower employment and remain in point $\mathrm{A}$. When in this case (i.e. the monopoly case)

8. It is important to realize that it is assumed that the preference structure of the employees is not affected by the change in taxes: in terms of Figure 8.1 , the relevant indifference curves remain I1, 12 and 13 , but they now represent different levels of the wage sum. 
taxes are levied on employers, the demand curve for labour will shift vertically downwards by exactly $\varepsilon$; it is represented in Figure 8.1 by nd'. Then the employees will choose a new wage, w1; which is at the same level of employment, 12 - cf. point B. The wage costs thus remain w2, which is also the wage in absence of taxes.

From these results one might be inclined to expect that also in the intermediate case, where neither employers nor employees have full bargaining power, $w c=w^{*}$ will be found. This is the case indeed, cf. equation (8.11). ${ }^{9}$ Take for example point $F$. Note that if this point represents the solution of the bargaining process before taxes, then it is a point of tangency of the Nash maximand and the demand for labour curve, see chapter 3. It can easily be derived that solving the Nash maximand without threatpoints (see footnote 6) results in an expression that is independent of employees' taxes. ${ }^{10}$ Consequently, it can be concluded that in a right-to-manage model without threatpoints the wage costs are independent of the tax rate. Only a change in the distribution of bargaining power, a change in the preference structure of the unions or a change in the demand for labour result in a change in the wage rate, and if there is no relation between a change in the tax rate and a change in these variables, this result holds. Note that the result implies that taxes are completely borne by employees. Further, it is concluded that although in this model only backward shifting occurs, it does not matter which side of the market is taxed, because the wage costs and the net wages are the same irrespective of whether employers or employees are taxed. Hence, Dalton's Law still holds.

\section{ii) the inclusion of threatpoints}

The core of the argument in the previous subsection is that taxes do not influence the preference structure of the unions. Further, the use of a proportional tax function causes independency of tax rates and wages. This implies that the trade-off between wages and employment and consequently, the slope of the indifference curve does not change. An increase in taxes only causes a decrease in the wage sum. Given the goal of maximization of the wage sum, taxes erode the value of this sum for the unions: a change in the wage employment combination cannot increase their after-tax income. It is now analysed how these results change when a threatpoint is included as in (8.68.8).

9 Note that in concluding $w c=w^{*}$ when either employers or employees have full bargaining power, I do not claim that both cases result in the same costs. If employees have full bargaining power, $w^{*}=w 2$, and if employers have full bargaining power, $w^{*}=w /$ and note that $w 2>w 1$.

10 The first order condition reads $(-\psi \cdot E . L(\Delta . W . L))+((Y-E . W . L) \cdot(1-\psi) \Delta))=0$ and hence $\Delta$ drops out. 
In this set-up, for the unions the threatpoint implies that the minimum acceptable after$\operatorname{tax}$ wage sum equals some fraction of total income. ${ }^{11}$ The same holds for employers: their minimum profit level is also a fraction of total income. In this model set-up, unions aim at maximization of the difference between the actual wage sum and the minimum acceptable wage sum, while for employers, the threatpoint implies that they strive after maximization of "surplus" profit, i.e. the profit that is reached above a certain minimum level.

Note that both for employers and employees, taxes are implicitly incorporated in the threatpoint. This can easily be seen when the threatpoints are expressed in terms of the bargaining item, the gross wage sum. Then one writes for the employers and the employees' threatpoints respectively

$$
\begin{aligned}
& W^{m 0} \cdot L=\frac{1-\chi}{\mathrm{E}} \cdot Y(L) \\
& W^{\min } \cdot L=\frac{\phi}{\Delta} \cdot Y(L)
\end{aligned}
$$

and note that the gross wage sum is the bargaining item.

If threatpoints are included in the analysis, equation (8.11) becomes a much more complicated expression, in which the wedge appears prominently. Instead of presenting the solution, I choose to give an intuition behind this result. Assume that employees' taxes increase. At first sight one is inclined to conclude that there is only a "direct" effect: at a given $\phi$, a change in $\Delta$ changes $\phi / \Delta$, and then the threatpoint $\mathrm{W}^{\mathrm{min}}$ (cf. 8.12b). However, there appears also an "indirect" effect, because an increase in employees' tax rate causes an increase in the gross wage sum demanded. Then, given the negative relation between wages and employment, both wages and employment change. Consequently, output changes and the threatpoint changes again. The same holds for employers. Thus the change in the wage rate that triggers off an employment and output change causes that the solution for the general outcome is more complicated. Or in more "technical" terms, in absence of the threatpoint, there is only one solution in the model, i.e. one optimal wage sum that maximizes both the before tax and the after-tax utility of the unions (proportional tax rates). With the threatpoint, the solution depends on the wage rate because of the influence on the threatpoint. Further, recall that the maximand for the union equals the difference between the

11 Note that unions in fact strive after a minimum net real wage sum, but because assuming a constant price level I "forget" about the real part. 
actual after-tax wage sum and the threatpoint wage sum. Both depend on the wage rate. One can however, verify whether Dalton's Law holds using Figure 8.1 again. The relation between wages and the threatpoint in this model means that the indifference curves are no longer straight lines. This implies that the marginal rate of substitution is no longer constant, but changes with the wage rate because of the corresponding change in the threatpoint. ${ }^{12}$ Hence shifts in the demand curve for labour, due to employers taxes, or in the isoquants, due to employees taxes, will lead to points of tangency which no longer lie above each other as is the case in the absence of threatpoints. This implies that it will matter which side of the market is taxed, as I have argued before.

I have calculated the results of the model for two situations: one without a threatpoint and one with a threatpoint. In order to be able to generalize these results, I will stress two points, the definition of union utility and of the threatpoint. As was argued in chapter 3 , maximizing the wage sum is only one out of a number of possible specifications of the utility function. For the analysis in this section it is important to note that this specification has the nice characteristic that in logarithms, the slope of the indifference curve $d(\ln W) / d(\ln L)=-1$, and thus independent of $W$. It is obvious that then the indifference curves are straight lines and I have argued that in this case Dalton's Law holds. Note that if $\mathrm{d}(\ln \mathrm{W}) / \mathrm{d}(\ln \mathrm{L})$ depends on $\mathrm{W}$, the indifference curve will be non-linear and as has been argued, then Dalton's Law does not hold anymore.

The threatpoint is defined such that it is related to the wage rate. An often used alternative definition for the threatpoint is that it is fixed. In the set-up in this chapter, this would imply that the threatpoint equals $\phi \mathrm{Y}^{\mathrm{f}}$, with $\mathrm{Y}^{\mathrm{f}}$ a fixed income (independent of $\mathrm{L}$ unlike the previous case). It can easily be derived that in this case the indifference curve (in logs) is again non-linear and consequently Dalton's Law does not hold. Only if employees have full bargaining power (in fact the monopoly model then appears) will the wage sum not change, because the maximum wage sum has already been reached. At this point it does not matter whether employers or employees are taxed. When both parties have bargaining power, Dalton's Law will not hold again. Finally, the findings concerning the relation between Dalton's Law and the right-to-manage model are summarized in Table 8.1.

12 I show this for the case that employees have full bargaining power in Appendix 8 . 
Table 8.1 Dalton's Law in the right-to-manage models

\begin{tabular}{|l|l|l|}
\hline Specification of the model $\rightarrow$ & without threatpoints & with threatpoints \\
\hline indifference curve has a $\downarrow$ & & \\
\hline constant elasticity & Dalton's Law holds & $\begin{array}{l}\text { Dalton's Law does not } \\
\text { hold }\end{array}$ \\
\hline elasticity depends on wages & Dalton's Law does not hold \\
\hline
\end{tabular}

\subsection{Empirical results: the Netherlands}

In the previous section I analysed the role of taxes and contributions for social security. It was shown that Dalton's Law does not always hold and hence it does malter whether employees or employers are taxed. The question remains, however, to what extent this is relevant for the Netherlands. This section starts with an overview of empirical results for the Netherlands, based on the models discussed in section 8.2. For obvious reasons I concentrate on the impact of employees' and employers' taxes in the Netherlands. It is clear that when different coefficients are found (or used), Dalton's Law is violated. ${ }^{13}$ The relevant coefficients of the various estimates of a wage equation are summarized in Table 8.2. The coefficients reported in that table represent the extent of shifting, measured by the elasticity of the wages with respect to employers' or employees' premiums. Next I present estimation results based on my own research for the Netherlands and the section ends with some remarks with respect to the impact of the Oort operation.

\subsubsection{Earlier research for the Netherlands}

Tax shifting research has been numerous in the Netherlands. In most cases an expression for wages is derived from a bargaining or a wage setting model. The general expression for the wage equation that follows from these kind of models is

13 Note that this statement holds only when wage costs or net wages are to be explained. The effect on gross wages differs as I have shown in the previous chapter (in particular with the help of Figure 7.1) and in the previous section where it was explained that Dalton's Law holds when employers succeed in full backward shifting and employees do not succeed in forward shifting. It is clear that the effect on wage costs is the same in both cases (zero effect), while the effect on gross wages differs (negative effect from changes in employers" taxes and zero effect from a change in employeest taxes). 


$$
w c=h(y-l, p, U, . .)+c_{1} \epsilon-c_{2} \delta
$$

where the first term at the right hand side of (8.13) expresses the idea that wages depend on labour productivity, on prices, on unemployment and other factors that differ between the various models. For the purpose of this section, $c_{1}$ and $c_{2}$ are relevant. The parameter $c_{1}$ measures the elasticity of the wages with respect to employers' premiums. Note that when $c_{1}=1$, the change in the wage cost is equal to the change in the employers' premiums: hence there is no shifting by employers. Further, since $\delta$ is the retention ratio, a decrease in $\delta$ implies an increase in employees' part of the wedge. The parameter $c_{2}$ therefore measures the extent of forward shifting. Table 8.2 presents an overview of research for the Netherlands where explicit attention is paid to taxes. ${ }^{14}$

Table 8.2 Tax elasticities

\begin{tabular}{lllll}
\hline Model & $\begin{array}{c}\text { Employers } \\
\left(\mathrm{c}_{1}\right)\end{array}$ & $\begin{array}{c}\text { Employees } \\
\left(\mathrm{c}_{2}\right)\end{array}$ & Wedge & Period \\
\hline FK & 0.85 & 0.25 & & $1954-1975 / 1978$ \\
FKSEC* & 0.80 & 0.36 & 0.46 & $1970:$ I $-1979:$ IV \\
MORKMON I & & & & $1971:$ II $-1987:$ IV \\
MORKMON II & 0.90 & 0.69 & $1958-1985$ \\
CESAM & 0.86 & 0.43 & & $1960-1980$ \\
& & & 1.04 & $1958-1981$ \\
Knoester (1983) & & & 1.15 & $1958-1982$ \\
Knoester/V.d. Windt & 1.00 & 0.93 & & $1960-1980$ \\
Knoester (1988) & 0.83 & 0.28 & 0.63 & $1958-1987$ \\
Van Veen/V.d. Veen & & & 0.46 & $1966-1988$ \\
Mulder (1990) & & 0.40 & & $1966-1988$ \\
Graafland (1990) & 0.91 & 0.28 & & $1965-1987$ \\
Graafland (1991) & 1.00 & & & \\
Lever (1993) & & &
\end{tabular}

* The model has been calibrated till 1990:IV

14 Of course, this is only a very small subsample of the research results available. However, in my view these results are representative. Apart from the large policy models, I have selected research that focuses more or less on tax shifting. Lewer is an exception, but his model fits perfectly well in the right-to-manage analysis of the previous section. 
The models that are most heavily used in economic policy are the FK/FKSEC model from the Central Planning Bureau and MORKMON from the Dutch Central Bank. Together with the CESAM model (CCSO, 1986) from the universities of Groningen and Twente, they belong to the large macroeconomic models for the Netherlands.

When one looks at the way tax shifting is modelled, one finds that in the FK model it is assumed that the elasticities of employers' and employees' premiums with respect to wage costs are 0.85 and 0.25 , respectively. In the multi-sector version of this model, the FKSEC model, these elasticities are estimated coefficients, with values 0.80 and 0.36 , respectively.

The first version of the MORKMON model, MORKMON I, shows an elasticity of the total wedge of 0.46 . Note that, in using the total wedge, it is implicitly assumed that employers' and employees' burden have a symmetric effect. Unfortunately without argument, this assumption is dropped in the MORKMON II model. ${ }^{15}$ The results of the MORKMON II model show long run elasticities of 0.90 and 0.69 , respectively. These results seem to support the decision to drop the symmetry assumption.

Finally, estimation results of the CESAM model are 0.86 and 0.43 , for the relation between a change in the wage cost and a change in employers' and employees' contributions, respectively.

Turning to specific studies, Knoester must be given credits for starting a discussion in the Netherlands concerning tax shifting and the belonging consequences. Knoester (1983) and Knoester (1988) are similar kinds of models. These are general models and model much more than the labour market alone. ${ }^{16}$ The model is estimated for The Netherlands, Germany, United Kingdom and United States. Knoester (1983) does not distinguish between employers' and employees' premiums, while Knoester (1988) does. Both studies conclude to significant forward shifting of taxes and social security contributions. Note how close the coefficients $c_{1}$ and $c_{2}$ are in his 1988 estimates, which might imply that Dalton's Law holds in his model as is implicitly assumed in Knoester (1983). ${ }^{17}$ Knoester and Van der Windt (1987) have developed a bargaining

15. It is interesting to note that in none of these macroeconomic models is a theoretical motiwation given for the distinction between employers' and employees" premiums. FKSEC even states: 'Although theoretically difficult to justify, the distinction consistently appears to be relevant empirically ..." (p.31).

16 These models consist of 5 blocks: supply, employment, effective demand, wages and prices and the public sector.

17 I have not checked this. However, if this equation is based on a similar model as Knoester and Van der Windt, then Dalton's Law holds in his model. 
model, without right-to-manage. In their estimates the authors do not distinguish between employees' taxes or employers" premiums. As was explained in section 8.2.1, Dalton's Law holds in their model -although the authors do not claim this. Hence, their method is fully in accordance with their framework. They estimate the elasticity of the total wedge with respect to the wage costs and find a coefficient of 1.15. The magnitude of the coefficient is high: this 'overcompensation' is not found in other research. Van Veen and Van der Veen (1988) estimated simultaneously a wage and price equation. Their estimates concern the development of the gross wage and are based on a Knoester type of model. They find elasticities of 0.83 and 0.28 for employers' taxes and employees' taxes, respectively. Because the gross wage is the dependent variable, they have to split between employers' and employees' taxes. Mulder (1990), who also estimated a wage equation without making a distinction between employers' and employees' contributions, distinguishes between short-term and long-term shifting. The short-term elasticity of the wedge is 0.33 , the long term elasticity equals 0.63 . The increase in the value from the short-term to the long-term is consistent with the conjecture of Blinder that was discussed in the introduction. Graafland (1990) derives a wage equation from a (bilateral monopoly) right-to-manage model, with insiders and outsiders. He finds an elasticity of the total wedge of 0.46 .

Graafland (1991) develops a right-to-manage model in which employers' and employees' taxes have been separated. The argument that he uses for this split is unclear: he states that "concerning the tax rate, we have split employees' burden from employers' burden. Although the theoretical model implies an identical effect, empirical arguments support the assumption that employers' burden is stronger than employees' burden" (p. 8). By stronger, he means that backward shifting is smaller than forward shifting, hence an increase in employers' burden by $1 \%$ has a stronger impact than an increase in employees' burden by $1 \%$ or $\mathrm{c}_{1}>\mathrm{c}_{2}$. Although his results show that if employers and employees' taxes are split, $c_{1}>c_{2}$, his empirical argument is not strong. This again stresses the need for a sound theoretical model in order to prevent ad-hoc assumptions. Because Graafland develops a right-to-manage model with a threatpoint that depends on the wage rate, I disagree that in this set-up $c_{1}=c_{2}{ }^{18}$ Further, his model incorporates both average and marginal tax rates. His results for average taxes are in accordance with the bilateral monopoly model with right-tomanage - cf. section 8.2 - while his results with regard to marginal taxes are in line

18 Graafland's way of solving this right-to-manage model means that he needs no profit furnction. Therefore he defines the net wage in the union utility function (my $\Delta . W$ ) as (WC $-T$. WC). Because I define $W C=E / \Delta . W N$ and Graafland defines $W C=1 /(1-T)$.WN, he implicitly substitutes $\mathrm{E} / \Delta$ for $1 /(1-T)$. The point is that in this way the difference between the effect of employers' and employees' burden is difficult to analyse because they are both locked up in $T$. 
with similar models (Hoel (1990), Padoa Schioppa (1990)). For the average tax rates he finds elasticities of 0.91 and 0.40 for employers and employees respectively. ${ }^{19}$ For the marginal tax rate of employees, he finds an elasticity of -0.11 .

Lever (1993) estimates a bilateral monopoly model. He finds an elasticity for employers" premiums equal to 1.0 , whereas the elasticity for employees' premiums $(0.28)$ is not significantly different from 0 . Hence, he finds that employers do not succeed in shifting increases in employers' premiums backwards nor does forward shifting occur. In the next section I expand on this model.

From these results I draw two conclusions. First, the answer to the question whether it is necessary to split employers' and employees' taxes and premiums in a wage equation (see footnote 15 and the discussion in Graafland, (1991)) depends on the theoretical model that one uses. Second, Dalton's Law probably does not hold for the Netherlands: it seems to matter which side of the market is taxed. In particular in the three macroeconomic models this result is found consistently. Although the results do vary, it does not seem unreasonable to assume that about $15 \%$ of employers' taxes is shifted backwards and about $35 \%$ of employees' taxes is shifted forward.

\subsubsection{An extension of the empirical analyses}

As follows from Table 8.2, most empirical estimates cover the period 1960 - 1985. In the empirical analysis I have extended the estimation period to $1960-1993$. This is interesting for two reasons: first; the robustness of the estimation results can be checked and second, as was discussed in chapter 6 , a major change in the composition of the wedge has occurred from 1990 onwards. Note that in the discussion of the results I focus on tax shifting parameters.

\section{The Lever model}

Since the Lever model could best be analysed, I chose to use this model for the estimates. Lever developed a model of union wage formation and labour demand, based on the monopoly union model (Lever, 1993, p. 32). The union maximizes a utility function with net wages and employment as the arguments. The weight that the union attaches to employment depends in turn on aggregate short term unemployment (u-ul) and the replacement ratio (b). Next, the wage equation is augmented with employers' $(\varepsilon$ ) and employees' taxes (measured by the retention ratio $\delta$ ) (including contributions for sociall security) to "translate" the net wage that follows from the

19 He states that these coefficients do not differ significantly from each other. In his opinion this is consistent with his theoretical model. However, he does not realize that wage bargaining is about gross wages and not wage costs. The analysis of section 8.2 shows that then Dalton's Law only holds under very special circumstances. 
maximization process into wage costs. Note that neither $\delta$ and $\varepsilon$ are explicitly incorporated in the utility function or the profit function. Referring to Table 8.1 , the Lever model is a model without threatpoints, but the elasticity of the indifference curve depends on unemployment and hence on the wages. Therefore one expects a different influence of employers" and employees" premiums on the wage costs: Dalton's Law does not hold in this type of model.

The employment equation is derived from a constant returns-to-scale production function of the CES type and using the marginal productivity condition. From this model the following labour demand and wage equation are derived: ${ }^{20}$

$$
\begin{gathered}
l=\gamma_{11} l_{-1}+\gamma_{12} l_{-2}+\left(1-\gamma_{11}-\gamma_{12}\right)\left[\gamma_{10}+\rho \alpha_{n} \sigma t-\sigma(w c-p)+y\right]+e_{1} \\
w c=\gamma_{21} w c_{-1}+\gamma_{22} w c_{-2}+\left(1-\gamma_{21}-\gamma_{22}\right)\left[\gamma_{20}+p+y-l+\gamma_{23} \ln (\epsilon)-\gamma_{24} \ln (\delta)+\gamma_{25} b+\right. \\
\left.\gamma_{26}\left(p_{c}-p\right)-\gamma_{27}\left(u-\gamma_{28} u l\right)\right]+e_{2}
\end{gathered}
$$

Equation ( 8.16$)$ is the labour demand equation. Note that the term between square brackets corresponds to $(8.9)$. In the wage cost equation $(8.17)$ the term between square brackets corresponds to (8.10). Note that as was explained in chapter 6 , the difference between $p_{c}$ and $p$ ( $p$ equals producer prices) captures changes in the terms of trade and indirect taxes. Further, Lever has estimated the wage and employment equation simultaneously. In this model full shifting of employers' taxes occurs when $\gamma 23=0$ (no shifting when $\gamma 23=1$ ) and full shifting of employees' premiums when $\gamma 24=1$ (no shifting when $\gamma 24=0$; recall that $\delta$ is the retention ratio). If employers do not succeed in shifting, an increase in their part of the wedge causes an increase in wage costs.

\section{The estimation results}

I have first reproduced the Lever data and his estimates for the period 1965-1987. The results closely resemble the Lever results and I concluded that the method of

20 For more details I refer to Lever, 1993, chapter 3. As one can notice in equations (8.16) and (8.17), it is assumed that labour demand and the wage rate follow an AR2 process to the equilibrium values. Further, note that all variables are in $\ln$ (except for $u$ and b). In the employment equation, $\alpha_{n}$ is the labour augmenting technical progress and $\sigma$ is the elasticity of factor substitution and equals $1 /(1-\rho), t$ is time, $p$ is production prices and $y$ is real income. In the wage equation wo is the wage costs (including all taxes), and $\varepsilon$ and $\delta$ are defined as before. Note that Lever denotes the wage costs by $w$ and further that $I$ have rewritten the wage equation in terms of $\varepsilon$ and $\delta$. 
reproducing the data and estimation technique could be used to extend the Lever results to a longer period. ${ }^{21}$

I have investigated the sensitivity of the results, both for the Lever estimates and for my estimates. First, as Lever reports, the 3SLS technique has been used and I have varied the instruments. These exercises showed that the results are rather robust concerning the use of the instruments. Second, Lever pegged the coefficient of the employers' premiums $(\gamma 23)$ to 1 . This implies that wage costs increase by the same amount as employers' taxes and hence there is no shifting of employers' taxes. I have estimated this coefficient freely in a number of specifications and found that this coefficient is indeed close to 1 , but the results deteriorated (sometimes "wrong" signs, insignificance of coefficients). I would have liked to test whether pegging to 0.85 (the "average" result for the Netherlands) is better than pegging to 1 , but I could not find any test for this.

Next, I estimated these equations for the period 1960-1993. The results worsened (in comparison to the period 1965-87). This was surprising. However, since major changes appeared in 1989/1990, I tried whether estimating over the period 1960-1990 would improve the results. ${ }^{22}$ It appeared, however, that the equations explained best for a subperiod, the period 1969-1990. It was not clear beforehand why this is the case. One guess might be that only from 1964 onwards, was free and normal wage bargaining incorporated in the Dutch labour relations (see chapter 2). In the early sixties (1963) the famous guided wage policy stopped and in the aftermath of this, one saw huge wage increases. I also investigated which subperiod within the period 1960-1993 would provide the best results, which turned out to be 1970-93. Substituting the period 19651987 for 1970-1993 yields better results despite the changes that took place in 1989/1990: employers" premiums decreased and employees' premiums increased. As a check for this result I performed a Chow test to check whether there was a structural change in the coefficients during the period 1970-93. All test were negative and consequently I did not find any structural change. Finally it should be noted that the results of the employment equation were rather robust during all the estimates and broadly correspond with Lever's result.

21 I thank Marcel Lever for providing me with part of the data. Note that the data are only for the private sector. The equations have been estimated with the 3SLS technique in TSP 4.1 and the lagged independent variables are used as instruments.

22 Of course, it is debatable what "better" results are. I have used two criteria: the signs must be in accordance to the theoretical expectation and second, I have taken a higher significance (t-values) as a better result. 
The estimation results for the period 1970-93 are presented in Table 8.3.

Table 8.3 Re-estimation Results, using the Lever equations, period 1970-1993

\begin{tabular}{lcll}
\multicolumn{2}{l}{ Employment equation } & & \\
$\gamma 11$ & 1.268 & $(10.0)$ & $\mathrm{SER}=0.007878$ \\
$\gamma 21$ & -0.508 & $(-4.67)$ & $\mathrm{R}^{2}=0.97$ \\
$\gamma 10$ & 2.35 & $(1.68)$ & $\mathrm{DW}=1.42$ \\
$\rho$ & -0.67 & $(-1.74)$ & \\
an & 0.03 & $(4.49)$ &
\end{tabular}

Wage equation

\begin{tabular}{llll}
$\gamma 21$ & 1.03 & $(5.6)$ & \\
$\gamma 22$ & -0.502 & $(4.7)$ & \\
$\gamma 20$ & 6.255 & $(20.6)$ & \\
$\gamma 23$ & 1.00 & & \\
$\gamma 24$ & 0.306 & $(2.2)$ & \\
$\gamma 25$ & 0.038 & $(0.13)$ & \\
$\gamma 26$ & 0.399 & $(0.73)$ & $\mathrm{SER}=0.010$ \\
$\gamma 27$ & 3.24 & $(3.76)$ & $\mathrm{R}^{2}=0.99$ \\
$\gamma 28$ & 0.15 & $(0.45)$ & $\mathrm{DW}=2.67$ \\
\hline
\end{tabular}

$T$-values are given between parentheses; $S E R=$ standard error of the regression; $R^{2}=$ correlation coefficient and DW $=$ Durbin-Watson test statiste

The results of the employment equation show a technical progress of about $3 \%$ per year and a factor substitution elasticity of -0.67 . With respect to the wage equation, the conclusions are similar to the results found by Lever. Concerning the tax variables, 1 have also fixed the coefficient of employers' taxes to 1 and find slightly higher forward shifting, $30.6 \%$, but more important, the significance of the coefficient has significantly increased. As in Lever, the replacement ratio shows a low and insignificant coefficient. The same holds for long-term unemployment. The t-value of the producers price gap has decreased, however, while the value of the coefficient is more or less in the same range.

I have further tested whether the coefficients of the employers' tax burden and of the employees' burden differ. Therefore, I have performed a Quasi-Likelihood Ratio Test for 3SLS to test for hypotheses in the model (see TSP, 4.1, user's guide, pp. $59 / 60$ ). This test is analogous to the Likelihood ratio test for OLS estimates. In this 
test the value of a minimum distance function is calculated, both for the null hypothesis and for the alternative hypothesis. The difference between the values of the minimum distance function has a $\mathrm{chi}^{2}$ distribution. Table 8.4 gives an overview over the results.

Table 8.4 Results of the QLR tests on the coefficients of the tax variables

\begin{tabular}{|l||l||l|l|l||}
\hline & If & H0 & H1 & result \\
\hline$(1)$ & & $\begin{array}{l}\gamma 23-\gamma 24= \\
0\end{array}$ & $\begin{array}{l}\gamma 23 \neq 0 ; \\
\gamma 24 \neq 0\end{array}$ & prob $(\mathrm{HO})<0.005$ \\
\hline$(2)$ & & $\begin{array}{l}\gamma 23=\gamma 24= \\
1\end{array}$ & $\begin{array}{l}\gamma 23 \neq 1 ; \\
\gamma 24 \neq 1\end{array}$ & prob $(\mathrm{H} 0)<0.005$ \\
\hline$(3)$ & & $\gamma 23=\gamma 24$ & $\begin{array}{l}\gamma 23 \neq \\
\gamma 24\end{array}$ & prob $(\mathrm{H} 0)<0.005$ \\
\hline$(4 \mathrm{a})$ & $\gamma 23=0$ & $\gamma 24=1$ & $\gamma 24 \neq 1$ & prob $(\mathrm{H} 0)<0.005$ \\
\hline$(4 \mathrm{~b})$ & $\gamma 23=0$ & $\gamma 24=0$ & $\gamma 24 \neq 0$ & prob $(\mathrm{H} 0)<0.01$ \\
\hline$(5 \mathrm{a})$ & $\gamma 24=0$ & $\gamma 23=0$ & $\gamma 23 \neq 0$ & prob $(\mathrm{H} 0)<0.005$ \\
\hline$(5 \mathrm{~b})$ & $\gamma 24=0$ & $\gamma 23=1$ & $\gamma 23 \neq 1$ & prob $(\mathrm{H} 0)<0.005$ \\
\hline$(6)$ & $\gamma 23=1$ & $\gamma 24=0.3$ & $\gamma 24 \neq$ & prob $(\mathrm{H} 0)>0.995$ \\
\hline
\end{tabular}

Recall first that $\gamma 24$ is the coefficient for the employees' taxes and $\gamma 23$ is the coefficient for the employers' taxes. The columns 2-4 define the null hypothesis ( $\mathrm{HO}$ ) and the alternative hypothesis (H1). Prob (HO) (column 5) is the probability that HO is true (with 0.005 being $0.5 \%$ ). The numbers in column 1 correspond with the numbers in the discussion of the hypotheses. I first tested the hypothesis that inclusion of tax variables does not significantly improve the estimation results (1). The hypothesis that both tax coefficients equal 0 is rejected. The same holds for the hypothesis that both coefficients equal 1 (2). Next I tested for the equality of both coefficients (this is implied in Dalton's law). The hypothesis of the equality is clearly rejected (3). I have also tested whether only complete forward shifting (4) or only complete backward shifting (5) is embodied in the results. The results of these tests are also negative. From (4b) and (5b) it follows, however, that also the hypotheses of no tax shifting at 
either side of the market is rejected. As can be expected, the outcome of $\gamma 24=0.3$, given $\gamma 23=1$ has the highest probability (6).

From this empirical research I conclude that the results of Table 8.2 are rather robust. Employers do not succeed in shifting of taxes much, while employees succeed in forward shifting of about $30 \%$ of an increase in taxes. However, in a number of cases, shifting coefficients need to be pegged to reach plausible results. Further I note that different periods provide different results. It is difficult to find consistent estimation results for the total period 1960-1993. The conclusion can certainly not be that it is easy to find empirical evidence for either the absence or the presence of shifting behaviour.

\subsubsection{The impact of the Oort operation}

It is interesting to apply these findings for the Netherlands to the results of the Oortoperation as presented in chapter 6 . There a shift in the composition of the wedge was concluded. At the macro level, employees' premiums and taxes increased from $50 \%$ to $58 \%$ of gross wages in the period 1989 - 1991. During that period employers" premiums decreased from $18 \%$ to $8 \%$. Hence a shift of about 10 percentage-points of gross wages took place from employers to employees.

It probably was assumed that this shift was wedge neutral, and hence would not affect wages. This is consistent with Dalton's Law. However, the findings above indicate that this Law does not hold, hence the wages will be affected. A decrease of employers' premiums by 10 percentage-points, corresponds to a growth rate of $\varepsilon$ of $8.5 \%$. Given an elasticity of 0.85 , this then would lead to a decrease in wage costs of $7.2 \%$. The increase in employees' taxes and premiums by 8 percentage-points corresponds to a growth rate of $\delta$ of $-16 \%$. This then would lead, given an elasticity of 0.35 , to an increase in wage costs of $5.6 \%$. The net result then would be a decrease in wage costs of $1.5 \%$. This is approximately neutrai.

One should realize that this result is not consistent with Dalton's Law. For, if shifting were neutral, with an elasticity of about $0.5 \mathrm{cf}$. Table 8.2 the net effect of the Oort operation would be an increase in wage costs of $3.75 \%$.

\subsection{Research in other OECD countries}

As I have showed in chapter 6 , the development in taxes and contributions for social security in the Netherlands has been similar to other OECD countries. This development has resulted in increasing attention throughout the OECD to the influence of tax changes on wage changes. Especially in the seventies and early eighties a number of studies were published that focused on this topic. Thereafter, the focus in 
wage setting shifted to the influence of unemployment (again) and tax variables now are standard incorporated in wage equations. In this section I will pay attention to a number of studies that explicitly focus on the relation between taxes and wages. Consequently, most of the studies date from 1970s and 1980s. In this "survey" I only pay attention to the countries that are taken into consideration in chapter 6 and to studies that discuss results for a number of OECD countries. Because the aim of this section is to give a short overview of the relevance of tax shifting in selected countries, I only present some interesting conclusions, without dealing extensively with the various models. Further, I claim not to present an exhaustive overview. For some reason(s), some countries have been more often used as a research object than others.

Van Rompuy et al. (1988) report results for tax shifting in Belgium. They develop a right-to-manage model with threatpoints and use the Nash solution to calculate the outcome of this model. They find that the elasticity of the gross wage rate with respect to employees' taxes and premiums amounts to 0.21 . They also find evidence for backward shifting: the elasticity with respect to employers' taxes amounts to -0.39. Results for Canada, France, Germany and Japan are reported in OECD (1978) and Knoester and Van der Windt (1987). The OECD takes the period 19641975 into account and concludes that no evidence of forward shifting can be found for France. This does not hold for Canada and Germany. Knoester and Van der Windt report a significant and positive relation between the tax wedge and real wages in Canada, France, Germany and Japan.

Malcomson and Sartor (1987) present estimation results for the relation between taxes and wages for the Italian industrial sector, period 1968:1-1980:4. They conclude, unfortunately without any comments, that increasing the level of income taxes by any means other than simply cutting the levell of tax-free allowances reduces the level of wages. ${ }^{23}$ Results for Italy from a monopoly model are further reported by Padoa Schioppa (1990). She seems to confirm the conclusion that was drawn in section (8.2.2). From the theoretical part of the paper she concludes that "the greater is the weight the union attaches to employment, the less it is willing to offset a tax wedge rise through higher wages. (..). If this weight does not vary as a result of a fiscal change, the compensation effect is said to be null, because for employment to remain constant, the labour costs has to be kept fixed: then the wage elasticity with respect to the direct tax is zero, while that to the social security equals -1." (p. 162) (note that social security contributions are borne by the firm). Further she concludes that the

23. They take only employees' taxes into account and wages are gross wages. Note further that they test various models against each other. In analysing the monopoly model (no threatpoints), they conclude that an increase in employees' taxes has no influence on the development of gross wages. Unfortunately, they pay no attention to this result. 
results change (i.e. shifting occurs) when a reservation wage is taken into account. As in my analysis, the marginal rate of substitution (mrs) between wages and employment is a crucial assumption in the analysis. Padoa Schioppa distinguishes between a constant $\mathrm{mrs}$, an mrs that depends on net real wages and an mrs that depends on both net real wages and the net real reservation wage. The results of the empirical estimates show that the marginal rate of substitution between the net real wage and employment depends on both the net real wage and the net real reservation wage. For this case, Padoa Schioppa shows that taxes can have positive, negative and zero effects on gross wages. ${ }^{24}$ Further, she finds evidence of both forward shifting (elasticity of 0.33 (gross wages)) and backward shifting (elasticity of -0.67 (gross wages)) for Italy. These results imply that Dalton's Law holds in her model.

Holmlund (1983) estimates a wage equation for Sweden for the period 1951-79. He shows that an increase in payroll taxes levied on employers by one percent is associated with a decrease in the money wage rate by approximately $0.5 \%$. An increase in the employees' income tax rate by one percent would produce an increase of the wage rate with $0.2 \%$.

In an article on the development of nominal wages in the United Kingdom for the period 1952-1971, Johnston and Timbrell (1973) conclude that "taxation changes have played an important role in wage negotiations in the sixties" (p. 156). Parkin, Sumner and Ward (1976), derive a wage equation for the United Kingdom from labour supply and demand functions. In their equation the effects of employees' and employers ${ }^{*}$ contributions for social security are measured. From the unrestricted estimates they conclude that, although the employers' tax variable is correctly signed and the employees" is not, "neither of the fiscal variables is significant" (p. 210). This conclusion holds only for the unrestricted estimations. If they impose (among others) the restriction that the sum of the tax coefficients equals -1 , the results show that employers have been able to shift about $70 \%$ from a change in their contributions backward on to labour. Nickell and Andrews (1983) also incorporate taxes. They use, of course, the right-to-manage model (with threatpoints). Their results for the period 1951-79 show that an increase in income taxes has a positive (insignificant) effect on real gross wages (elasticity of 0.47 ). For employers taxes, the elasticity equals $\mathbb{1}$; hence there is no backward shifting.

For the United States Gordon estimated various wage and price equations. In Gordon (1971), it is concluded that during the period 1954:1-1970:4 employees

24 More precision is needed: in the last case, Padoa Schioppa assumes that the mrs depends positively on the net real wage and negatively on the net real reservation wage. Hence, if as a results of a change in taxation, both the net real wages and the net real reservation wage change, the effect on mrs and hence on the wage rate is ambiguous. 
succeeded in shifting $14 \%$ of their burden on to employers. Employers were not able to shift their part backward on to wages. ${ }^{25}$ However, in other research for the period 1954:2-1980:4, Gordon (1982), can no longer find a significant influence of a social security tax variable (both employee and employer shares). This conclusion still holds when he estimates wages and prices simultaneously. Neither in the wage nor in the price equation there is a significant coefficient of a tax variable. Finally, in Gordon (1987), the existence of a significant tax push effect is denied. Vroman (1974) concludes from his research covering the period 1956:1 to 1969:4, that it seems reasonable to think that some part of the employers payroll taxes is shifted backward on to labour. These results are in line with those of Hamermesh (1979), who concludes that at most only a small part of any tax increase (for employers) is ever shifted backward on to labour. His conclusion is interesting because it is based on research using microdata, whereas almost all other research uses macrodata.

The discussion above seems to be rather confusing. But the results may point into the direction of a difference between Europe and the United States (see also Tullio 1986, p. 756); the difference being that the degree of forward shifting in the United States (and Japan) has been significantly lower than in Europe. Musgrave and Musgrave (1987) also express themselves in this way: in the United States unions traditionally respond to changes in the cost of living but not to tax-induced changes in take home pay (p. 278). These conclusions are partly confirmed by Knoester and Van der Windt. They conclude from their research into the relation between real wages and taxation in ten OECD countries (1958-1981): "Our analysis provides strong empirical support for the occurrence of a shifting forward of direct taxes and social security contributions. This shifting forward appears to be a significant determinant of real wages in all countries". But there are differences between the countries because "The estimated coefficient varied between half and one in most countries. We found the lowest value for the US and the highest for Australia, Italy, Japan and the Netherlands." From

25. This interpretation of the results of Gordon seems to contradict the interpretation of Vroman who concludes that "Gordon, on the other hand, found complete backward shifting which takes place over a four quarter interval" (p. 202). Nevertheless, both interpretations are correct. This follows from the result of the unconstrained estimates in which no lags are assumed. The coefficient of employers' social security payments behaves around +1 (dependent variable $=$ gross wages + social security payments by employers). However, if Gordon imposes a lag structure in his model, the conclusion of Vroman is valid. But in my view, the restrictions are such that this outcome must appear (current coefficient $=+1_{b}$ coefficients in all other periods must be negative, decreasing and add to -1 , thus making the sum of the coefficients zero). Moreover, from the listed tables it is not clear how significant the estimates of the lag structure are. Therefore, I prefer my interpretation. 
Knoester $(1983 ; 1988)$ a similar conclusion can be drawn: in both studies forward shifting is highest in the Netherlands, followed by Germany, UK and the US. Moreover, the coefficient for the Netherlands appears to be about twice as high as for the US. On the contrary, Coe and Gagliardi (1985) cannot find significant tax effects on wages in their research into nominal wage determination in ten OECD countries (according to Coe and Gagliardi their estimation results cover the period "mid-sixtiesearly eighties semi-annual observations"; further they take the same countries as Knoester and Van der Windt into account except for Sweden which substituted for Austria). Unfortunately, they do not give an explanation for this result. In another OECD research (OECD, 1978), covering the period 1.964-1975, mixed results with respect to tax shifting were found. Significant (in the statistical sense) evidence for forward tax shifting was found for Belgium, Canada, Germany and Sweden, while the results for France, the Netherlands, the United Kingdom and the United States were insignificant. Similar results concerning the influence of the wedge in the wage equation have been found by Bean, Layard and Nickell (1986). They estimate a wage setting equation for $18 \mathrm{OECD}$ countries. Because they present reduced form equations it is difficult to analyse the model behind the estimated equations. Their results are remarkable. For six countries, the wedge shows the "wrong" sign. Bean et al. expected a positive sign and yet a negative sign was the result. For another six countries the wedge has the expected sign and the coefficients are significant. For the remaining third, the coefficients are insignificant. ${ }^{26}$ Note further that both high wedge countries such as the Netherlands and Italy and low wedge countries like Canada and the United Kingdom are found among countries that show insignificant effects of the wedge. The same holds for the cases where a significant effect was found.

\subsection{Conclusions}

This chapter discusses the same question as the previous chapter: does it matter which side of the market is taxed? The relevance of this question stems from the ongoing trend in the Netherlands which shows a shift from the employers' to the employees" part of the wedge. The tax reform that started in the 1990s in the Netherlands has given an extra impetus to this trend. In contrast to the previous chapter, this chapter analysed the influence of taxes in wage bargaining models. It can be concluded that no general answer can be given to the question whether it does matter which side of the bargaining parties is taxed. The reason is that especially the way the threatpoint is defined influences the result. Only in absence of threatpoints and in case the

26 I define significance by a T-value of at least 2 . 
indifference curve of the union has a constant elasticity, Dalton's Law holds in the simple bargaining model that was discussed. In this model, if there is no threatpoint, the bargaining results in an optimum wage sum for the unions. Although taxes erode this wage sum, unions cannot improve their bargaining result by bargaining for another wage sum. If $I$ define a threatpoint in terms of a minimum acceptable share of national income, then an increase in taxes causes a change in both wages and employment causing a change in the threatpoint, which again causes a change in wages and employment and this results in a different solution than the starting point. And since the effect on the threatpoint differs, it matters which side of the market is taxed. If the elasticity of the indifference curve depends on the wage rate, Dalton's Law neither holds, even in absence of threatpoints. The reason is that taxes then influence the union's trade-off between wages and employment and hence the unions may bargain for another wage sum. The findings were next applied to a model that was developed by Lever.

A variety of results is found in empirical research concerning the relation between taxes and wages. For the Netherlands, the results indicate that about 35\% of the taxes is shifted forward and about $15 \%$ is shifted backward. The results for other OECD countries are mixed, although the main differences exist between the United States, Japan and the European countries. The latter show higher shifting coefficients. Concerning this latter group, in chapter $6 \mathrm{I}$ investigated the magnitude of the wedge for various countries, If I combine the research that I reviewed in this chapter with the data of chapter 6,1 find that no clear-cut conclusions can be drawn concerning the question whether shifting is higher in countries where the wedge is highest, although some of the evidence of Knoester and Van der Windt (1987) points into that direction.

This chapter finishes part II of my studies. In chapter 6 I investigated the magnitude of the wedge and concluded that first the magnitude is high in de Netherlands and second that the composition of the wedge differs remarkably between countries. According to chapter 7, this difference does not matter for the wage cost and employment result on the perfect competitive labour market. However, chapter 8 argues that a wage bargaining model is better suited to analyse the impact of the wedge and I found that only under rather strict conditions the composition of the wedge does not matter. Chapter 8 focussed on a right-to-manage model of the labour market. As I have argued in chapter 2 and in chapter 3, however, this model does not fully cover the rich insitutional characteristics of wage bargaining in the Netherlands. In the next chapter I discuss a model that in my view better suits the Dutch process of wage negotiations. 


\section{APPENDIX 8}

In this appendix I solve the extended right-to-manage model (with threatpoints) for the case that employees have full bargaining power. I show that then the slope of the indifference curve is not linear anymore.

If employees have full bargaining power, one must solve

$$
\underset{W}{\operatorname{Max}}\{\Delta \cdot W . L-\phi . Y\}
$$

$$
\text { S.T. } Y / L=k .(E . W)^{\circ}
$$

This comes down to maximizing

$$
L .\left\{\Delta . W-\phi . k .(\mathrm{E} . W)^{\alpha}\right\}
$$

and one finds

$$
W / L . d L / d W=-\left(\Delta . W-\phi . \sigma . k .(\mathrm{E} \cdot W)^{\circ}\right) /\left(\Delta \cdot W-\phi \cdot k \cdot(\mathrm{E} \cdot W)^{\sigma}\right)
$$

The left hand side of equation (8A.3) is the elasticity of employment with respect to wages along the indifference curve. It is clear that this elasticity depends on $\mathrm{W}$ and that the relation between $\ln W$ and $\ln L$ is not linear anymore. 


\section{PART III TAXES IN A THREE-TIER WAGE BARGAINING MODEL: The case of the Netherlands}

Part III consists of chapter 9. In this chapter I develop a wage bargaining model that captures a number of characteristics of wage bargaining in the Netherlands, as I have discussed in the previous chapters. In particular, attention is paid to three levels: the central level, the industry level and the firm level. Second, the model focuses on the impact of taxes in wage bargaining. I argue that public goods are an argument in the utility function of the encompassing union and extend the model that was developed in chapter 4 to incorporate taxes in firm-level bargaining. 


\section{Chapter 9}

\section{A MODEL OF TAX SHIFTING IN A THREE-TIER WAGE BARGAINING SYSTEM}

This chapter presents a model for wage bargaining in the Netherlands. Jhe aim is to Incorporate the specific features of the Dutch labour relations as has been outlined in chapter 2, into this model. It is argued that in the Netherlands a three-tier framewowk is the best approach to nodel the wage setting process. The nodel starts with the central level and ends up with the level of the individual. $A$ key issue concems the role the role of taxes in the nodel It is contended that the responsiyeness of the wages to tax increases depends on the level of wage bargaining.

\subsection{Introduction}

Chapter 2 discussed the Dutch system of wage negotiations. Despite its complexity, one can conclude that both consultations at the central level and industry negotiations exist. In addition, there is wage drift in the Netherlands implying that the final wage is determined in negotiations between firms and individual employees. Further, I have presented the development of taxes and premiums for social security, both for employers and for employees in chapter 6. It was concluded that the composition of the wedge has seriously changed: a shift from employers" to employees' premiums occurred during the $1980 \mathrm{~s}$ in the Netherlands. Further, the total wedge increased during the period 1960-1980. This was followed by a decrease in the 1980s. Subsequently I went on to analyse the effects of taxes in chapters 7 and 8 , both in market clearing and in bargaining models.

In order to be able to model wage determination in the Netherlands and focus on the role of taxes, I took a closer look at the concept of wage bargaining in chapter 3, where I analysed modern approaches to the economics of trade unions and to unionemployers bargaining. It was concluded that not only pure wage bargaining but also bargains about both wages and employment can be used to describe union-employers bargaining. After this general picture, I discussed bargaining at the level of the firm in chapter 4 and the merits and demerits of centralization of wage negotiations in chapter 5.

This chapter aims at developing a model that first covers the specific Dutch features of the wage negotiations and second focuses in particular on the role of taxes. The model is based on the previous chapters in line with Booth's assertion (1995) 
"[...] both the bargaining structure and the bargaining coverage are institutional features of an economy that need to be considered before constructing an aggregate model of the labour market" (p. 256).

As I have sketched in chapter 2 , in the Netherlands there are meetings at the central level, at the level of the industry/large firms and between individual employers and employees. Hence, one can distinguish three levels where wages are subject of discussion. This chapter discusses three questions:

1. How can wage negotiations at the various levels in the Netherlands be modelled?

2. What are differences/similarities and what is the relation between the various levels?

3. What are the conclusions concerning tax shifting from the analysis?

The chapter is organized as follows. The next section discusses the relation between the model advanced here and existing models that discuss two-tier wage bargaining. This will clarify the special characteristics of Dutch labour relations. Section 9.3 starts with the central level. Next, section 9.4 analyses the industry level and finally section 9.5 the individual level. This chapter ends with the conclusions in section 9.6.

\subsection{Relation to other literature concerning multi-tier wage bargaining}

Two features are important in this chapter. First, the model is derived from the specific bargaining structure that exists in the Netherlands: I will extensively pay attention to the various levels that cletermine this structure. Second, it is assumed that the willingness to pay for the provision of public goods differs between the various levels of consultations/negotiations. These are quite acceptable assumptions for the situation in the Netherlands, but I have not seen as yet a model that analyses this thoroughly.

This chapter is an extension of the literature where two-tier wage setting processes are heavily discussed (Holden (1988), Moene (1988), Johansen (1995) among others). Most of this literature is based on the situation in Norway and Sweden. The Holden/Moene type of models (see also chapter 4 where I discuss wage drift and the Holden model) are best described by Johansen. He states "(..) the wage level, after local wage bargaining, is set as a mark-up on the contractual wage. We assume that the local bargainers take the outcome from the central contract settlement as given, while the central organizations take into account how contractual wages affect the final outcome. Hence, we interpret contractual wage increases as instruments to adjust actual wages towards the path desired by the central bargainers" (p. 2). 
However, there are two major differences between centralization of wage bargaining in Sweden/Norway and in the Netherlands. In the Scandinavian countries, there is in fact bargaining at the central level and there is coordinated wage setting. As has been sketched in chapter 2 , in the Netherlands there is no central wage bargaining, resulting in a wage settlement or the like. In the Netherlands the central level aims to coordinate wage bargaining at the level of the industry. Second, in Sweden/Norway after the central bargaining (the first stage) there is bargaining at the firm level (the second stage). Parties are familiar with this kind of two-tier wage setting. In the Netherlands, after there have been consultations at the central level, actual wage bargaining starts at the industry level, resulting in binding contracts. Thereafter, employees try to increase their wage at the level of the firm, causing wage drift. Consequently, in the Netherlands there is in general no union-firm bargaining. Further, a specific characteristic of the situation in the Netherlands is the relation between the central level and the industry level. On the one hand, there is no specific central bargaining, although now and then central agreements are concluded with sometimes concrete guidelines for wage increases (see chapter 2 and Table 2.3 in particular). On the other hand, the umbrella unions do have relevant influence on the industry unions. Since I aim to incorporate the specific institutional characteristics of the Netherlands in the model, I have to capture these relations.

The approach basically is the following. I assume that the preferences of the encompassing unions differ from the preferences of the industry unions. Further it is assumed that the type of "bargain" model that underlies the central consultations differs from the bargain model at the industry level. Finally, I extend the model of wage drift (see chapter 4) and include taxes.

The preferences of the encompassing unions differ because they are concerned. with nationwide economic issues instead of industrywide issues. This implies, for example, that these unions care about a good, nationwide system of collective benefits, while industry unions care about industry-specific arrangements. Further, one can argue that at the central level nationwide employment and unemployment are important variables, while at the industry level the employment situation in that industry matters. Hence at the central level externalities are internalized (see also chapter 5). Next I assume that for the Netherlands an efficient bargain solution is the best way to approach the result of the central consultations, while the right-to-manage model is best suited for an analysis of industry negotiations. The main reason behind this assumption is that in the central consultations, wages, employment and collective arrangements are discussed, while at the industry level there are no explicit agreements about employment (e.g. manning rules or the like) concluded. A second reason is that 
one might wonder why parties do not reach Pareto efficiency. Or, to quote Calmfors in discussing wage bargaining models $(1985$, p. 158$)$, "In all cases, the optimization paradigm would lead us to believe that there are strong incentives for all parties to eliminate inefficiencies, since everyone could gain". The "classical" answer is that the Pareto optimum is not reached because of the danger of cheating (cf. the instability of the Nash bargaining solution as I have discussed in chapters 3 and 5). But this danger does not play a role at the central level, because there are no contracts concluded. And in so far as they are concluded, they contain no commitments to employment levels for the individual firms. Finally, as in chapter 4 , I assume that at the firm level there is wage bargaining. However, referring to Oswald's inverse seniority model, it is assumed that individual employees do not care about employment as long as they are employed themselves. One can summarize the framework of the model as in Table 9.1.

Table 9.1 A framework for a model of wage bargaining in the Netherlands

\begin{tabular}{|l|l|l|l|l||}
\hline level & result & model & parties & goals \\
\hline \hline \begin{tabular}{l|l|l|l} 
central \\
level
\end{tabular} & $\begin{array}{l}\text { guidelines about } \\
\text { wages, employment } \\
\text { and if necessary, } \\
\text { social security } \\
\text { payments }\end{array}$ & $\begin{array}{l}\text { efficient bargain, } \\
\text { including valuation of } \\
\text { public goods }\end{array}$ & $\begin{array}{l}\text { encompassing } \\
\text { organizations } \\
\text { of employers } \\
\text { and employees }\end{array}$ & $\begin{array}{l}\text { a warranted } \\
\text { package of } \\
\text { labour conditions } \\
\text { including the } \\
\text { provision of } \\
\text { public goods }\end{array}$ \\
\hline
\end{tabular}

\begin{tabular}{|l|l|l|l|l||}
\hline $\begin{array}{l}\text { industry } \\
\text { level }\end{array}$ & $\begin{array}{l}\text { binding wage } \\
\text { contracts (gross } \\
\text { wages and if } \\
\text { necessary, social } \\
\text { security payments) }\end{array}$ & $\begin{array}{l}\text { right-to-manage, } \\
\text { taking the trade-off } \\
\text { between Jabour } \\
\text { demand and the wage } \\
\text { rate into account }\end{array}$ & $\begin{array}{l}\text { industry unions } \\
\text { and employers } \\
\text { organizations }\end{array}$ & $\begin{array}{l}\text { maximization of } \\
\text { union's utility } \\
\text { given the } \\
\text { constraint of } \\
\text { labour demand }\end{array}$ \\
\hline
\end{tabular}

\begin{tabular}{|l|l|l|l|l||}
\hline $\begin{array}{l}\text { firm } \\
\text { level }\end{array}$ & $\begin{array}{l}\text { wage drift } \\
\text { (gross wages) }\end{array}$ & $\begin{array}{l}\text { right-to-manage, } \\
\text { without bothering } \\
\text { about the relation } \\
\text { between wages and } \\
\text { employment }\end{array}$ & $\begin{array}{l}\text { individual } \\
\text { employee and } \\
\text { the firm }\end{array}$ & $\begin{array}{l}\text { maximization of } \\
\text { the difference } \\
\text { between actual } \\
\text { earnings and the } \\
\text { contract wages }\end{array}$ \\
\hline
\end{tabular}


In my view, two new elements are added to the existing research. First, in the Scandinavian research programs, an analysis of the responsiveness (at the various bargaining levels) of employment to wage increases is an important goal. I am, however, mainly interested in the responsiveness of wage increases to tax increases at the various levels. I have not seen similar research on this topic before. Second, the assumption that models can vary over the bargaining levels has, to my knowledge, not been used before. Note finally that I do not assume complete information in the game but assume a sequential bargaining process starting with the central level and ending at the level of the firm.

This model differs from union models with endogenous government spending (Driffill (1985), Gylfason and Lindbeck (1986), Abraham (1989) among others). In those models government has a certain employment goal and unions know that if their wage bargain results in too low a level of employment, the government will try to increase employment by using monetary and/or fiscal policy. This influences the bargaining setting and consequently unions will change their strategy and try to exploit this government objective by increasing the wage rate. ${ }^{1}$ This problem is known in the literature as the 'accommodation dilemma' (see also chapter 5). The model in this chapter does not discuss this dilemma for a few reasons. First, in the model that is developed in this chapter, although government is not a participant in the consultations, there is continuous discussion between government, unions and employers' organizations. This strongly hampers exploitation. Second, one can imagine that in case of only industry-level bargaining, each union (knowing the employment goal of the government) has an incentive to increase the wages because if it does not while other unions do, it will face a relative deterioration. Or, alternatively, wage moderation will only be an optimal strategy if other unions moderate their wages as well. This problem does not occur at the central level and hence there is no upward pressure on the wages because of fear of a deterioration of one's relative position. Third, I argue that the core of the central consultations in the Netherlands is the discussion of the trade-off between wage increases and the alternatives (such as employment, but also public goods). Or, to put it differently, one can argue that the reason for the existence of central negotiations is to avoid the accommodation dilemma.

Finally, note that I assume that the government strives after a balanced budget. If at the central level, wages are "agreed upon" at such a level that expenditures for unemployment benefits increase, tax tariffs will increase and the unions and employees

1 In these models the slope of the indifference curve does not change, but the slope of the (aggregate) demand for labour curve increases because the price that must be paid for a wage increase decreases. 
need not gain from a higher wage. This line of argument is, for example, used by Mulder (1989, chapter 2).

\subsection{The central level}

\subsubsection{A model of central consultation}

In chapter $2 \mathrm{I}$ argued that the role of the central level is rather unclear in the Dutch labour relations. However, at one point the role is clear: since 1964 there have been no negotiations that result in specific wage and/or employment contracts at the central level. At best there are consultations between confederations of unions and employers, now and then chaired by government representatives. These consultations sometimes result in some kind of framework for union/employers" policy, mostly consisting of guidelines about wage developments. Table 2.3 in chapter 2 gives an overview of the results of the yearly consultations. Moreover, as we have argued in chapter 2 , there is a certain influence from the central consultations on the industry negotiations.

This section discusses how one can incorporate the central level in the Netherlands into a model of wage determination. I will sketch a framework where confederations of employers and of employees discuss wage and employment policies and the provision of public goods. Note that the "highest" level of consultations is analysed. For in the Netherlands three confederations of unions and seven confederations of employers' organizations participate at this level in the discussion. ${ }^{2}$

\subsubsection{The behaviour of unions and employers}

\section{Union utility}

It is assumed that the preferences of the unions can be described by a Stone-Geary utility function. At this central level, union's utility depends first on real net wages $\left(\delta\left(W-W^{m i n}\right)\right.$. Second, unions care about employment $(L)$. Third, I assume that unions' utility also depends on public goods (G). Hence I can write

$$
U(W, L, G)=\left(\delta\left(W-W^{\min }\right)\right)^{\gamma}(L)^{\theta}(G)^{(1-\gamma-\theta)} \quad 0<\delta, \gamma, \theta<1 ; \gamma+\theta<1 .
$$

where $U(W, L, G)$ denotes the utility of the confederations of unions, $\delta$ is defined as the retention ratio, $W^{\mathrm{min}}$ is the minimum wage that is desired by the union and is assumed exogenous during the analysis. $\gamma$ is the utility elasticity of the net wages $(\mathrm{dU} / \mathrm{d}(\delta(\mathrm{W}-$

2 The discussions are held in the Foundation of Labour (Stichting van de Arbeid) between FNV, CNV and MHP (employees) and VNO, NCW, KNOV, NCOV, KNLC, KNBTB, NCBTB (Albeda and Dercksen, p. 40). See also chapter 2. See appendix 2 for the full names of the abbreviations. 
$\left.\left.W^{\min }\right)\right)\left(\delta\left(W-W^{\min }\right)\right) / U .{ }^{3}$ In the same way $\theta$ and $(1-\gamma-\theta)$ are the utility elasticities with respect to employment and government expenditures; respectively. As in the previous studies, the price level will be kept constant and equal to 1 throughout the analysis, so one can write $W$ instead of W/p. Note further that I use a different utility function from the one I used in the previous chapter: in the specification in this chapter I assume that the threatpoint is defined in terms of gross wages. Then taxes do not influence the magnitude of the threatpoint, but the net value of this threatpoint. Because "bargaining" is about gross wages, I find this definition of a threatpoint more appealing.

Equation (9.1) expresses the usual idea that the utility of the union depends on real net wages and employment (Pencavel (1991), Booth (1995)). This function differs, however, from other specifications because of the introduction of public goods (G) in the union utility function. Hence, I assume that at this central level, unions attach some value to public goods. One of the consequences is that, at a given wage level, an increase in taxes has two effects: on the one hand it decreases utility via a decrease in the net wage, while on the other, if the tax receipts are used to provide public goods, union's utility increases. Consequently a tax increase does not have a negative effect on union's utility per se. Note that in this utility function various substitution possibilities are incorporated. For example, an increase in both taxes and collective insurances/benefit payments may leave the utility of the union unaltered and so the union might be willing to pay voluntarily for the tax increase.

This function seems an adequate description of the preferences of the confederation of unions in the Netherlands. In the periodical consultations, discussions are not only about wages. Items like employment, income transfers, schooling, collective insurances etc. are an important part of the agenda.

I will briefly elaborate the notion that more public goods increase the utility of the union. ${ }^{4}$ This assumption implies that an increase in both taxes and government expenditures does not necessarily decrease union's utility and consequently unions might be willing to pay for the provision of public goods voluntarily. This idea of

3 Note that in the previous chapters $\delta$ was defined as In (retention ratio). In this chapter I do not use In's and for sake of readability, I choose to use $\delta$ to represent the retention ratio. The same holds for $\varepsilon$.

4 One nust be careful in defining a good as a public good. In this chapter, however, I take a broad approach and view public goods as those goods that are discussed in the meetings between employers and employees, e.g. collective insurances, welfare payments and schooling. Hence 1 do not exclusively mean non-rival and non-exclusive goods. Further, contrary to Gylfason and Lindbeck (1986) I focus on that part of government spending that is regarded by the unions as a substitute for private consumption in their utility function. These are what I call 'public goods'. 
voluntary payments for public goods is very uncommon because of the free-rider problem. Why should people pay for a good that is provided to them anyhow, even when the good increases their utility? Would it not be preferable that "others" (e.g. employers) pay for the goods that union members also receive? This problem has been analysed by Olson (1971). He basically approaches the problem of the payment and the provision of a public good by using cost-benefit analysis: if the benefits of a public good for at least one member of the benefitting group exceed the cost, then the good will be provided. The reason is clear: even if the member for whom the benefits exceed the costs has to pay for the good alone, he will buy it. Olson then concludes that in small groups the provision of public goods and the voluntary payment for these goods is more likely than in large groups. He uses two arguments for this conclusion. First, the probability that the benefits exceed the cost for a group member is larger in small groups than in large groups. Second, because of increased possibilities for monitoring, the free-rider problem is smaller in small groups than in large groups. The upshot is that in small groups parties are more inclined to pay for the provision of public goods.

In my view, Olson's ideas can be applied to the consultations at the central level. The question is whether there will be voluntary payment for public goods by the central unions. ${ }^{5}$ Since the consultations are held between employers" confederations and unions, I analyse their positions. Employers have no interest in the provision of public goods, although it may save negotiation costs. It seems not a bad guess that, from the perspective of the employers, the costs outweigh the benefits. ${ }^{6}$ The position of the central organization of unions differs. I give four arguments. First, unions owe their very existence to the fact that they have been successful in providing public goods. Especially in the Netherlands, unions supply only a few goods exclusively for their members. Second, the public goods that are subject of discussion in the central consultations are largely provided to that group whose interests are served by the

5 Again I stress that there are no negotiations at the central level. However, the central organization of the unions coordinates the industry bargaining mainly by advising the unions about the wage demand. So what actually is meant here is whether the central organization of unions wants to trade off public goods against a lower wage recommendation.

6 This guess is based on three arguments. First, in the Netherlands one distinguishes in the social security system between employees insurances (unemployment benefits, sickness benefits, etc.) and collective insurances for all inhabitants of the country (e.g. welfare payments). Small employers (self-employed people) were prevented from participating in the employees' part of the collective insurance systems in the Netherlands. Second, big employers can as well create their own insurance by just putting part of the profits aside. Third there seems to be less solidarity among employers than among employees. Consequently, they are less eager to pay contributions that will benefit their colleagues. 
unions: both employees and unemployed belong to the unions. Third, solidarity has been strong among unions in the Netherlands. This is not only the "merit" of the industry unions, but the confederation of unions has for years succeeded in uniting the different industry unions. This is important because otherwise only industry arrangements would be concluded. Fourth, unions realize that if they are not prepared to pay for the public goods, these goods will not be provided as public goods. Unions are aware that at the central level there is no free lunch.

I conclude that the benefits for the unions are high and as long as the benefits exceed the costs, they are prepared to pay voluntarily for these goods. I basically assume that the discussions in the foundation of labour are characterized by small group behaviour in the sense of Olson where benefits of the public goods exceed the costs for the union and that thus the confederation of unions is prepared to pay voluntary for the provision of the public goods. In other words, I conclude that tax shifting at this level does not occur per se. Recall that equation (9.1) describes the utility of the confederation of unions, not of an industry union.

The idea that unions value public goods has also been used by other researchers, e.g. Gylfason and Lindbeck (1986) and Lockwood and Manning (1993). Gylfason and Lindbeck (1986) argue "We assume the unions to be concerned not only with real disposable wages and employment, but also with the level of government spending. Specifically, we assume that the unions consider themselves better off, ceteris paribus, when real government spending on goods and services rises (either because union members consume goods and services provided by the government or because of the ideological commitment of union leaders to public spending)". Lockwood and Manning (1993) assume that only the net tax rate appears in the utility function. The net tax rate is equal to the taxes minus the benefits (and of course this net sum is divided by an income variable). Hence, the utility of public goods is incorporated implicitly in their model. The difference with the set-up in this chapter is that here we do not claim that unions value taxes and benefits in the same way. Further, this chapter's set-up permits a more thorough analysis of the role of public goods.

1 next assume that the amount of public goods is determined by the budget constraint: the government aims at a balanced budget. Since tax income is equal to ( $\varepsilon-$ б).W.L, the budget constraint reads ${ }^{7}$

$7 \varepsilon$ is defined as $1+[$ employers' premiums for social security/gross wages] (see also footnote 3 ). Hence $(\varepsilon-\delta)$ equalls the wedge. 


$$
G=(\epsilon-\delta) \cdot W \cdot L+T
$$

and (9.2) simply expresses that the level of government expenditures is equal to the tax receipts. The tax receipts are partly determined by the wage sum (income taxes) and partly independent of the wage sum (indirect taxes, T). In the following analysis I will assume that $T$ is constant.

One can derive an indifference curve from equation (9.1) and find

$$
\frac{d W}{d L}=-\frac{\left(U_{L}+U_{G} G_{L}\right)}{\left(\delta U_{W}+U_{G} G_{W}\right)}
$$

Note that if $U_{G}=0$, one finds the usual expression for the slope of the indifference curve when unions care about net real wages and employment. The only difference is that the slope now explicitly depends on the on the marginal utility that is attached to public goods. Consequently, the slope does not only reflect the marginal rate of substitution between real wages and employment, but also the marginal rate of substitution between real wages and public goods. Note further the role of the retention ratio: an increase in employees' taxes changes the trade off between the arguments of the utility function because an increase in wages is less valuable after the tax increase.

\section{Employers' behaviour}

Employers' behaviour is motivated by profit maximization. Profits $(\pi)$ are defined by

$$
\pi=R(L)-\epsilon . W . L
$$

where $R(L)$ is the well-behaved production function. ${ }^{8}$ From $(9.4)$ one can derive isoprofit curves (see also equation 3.9 )

8 Of course, one might wonder whether public goods should not also be incorporated in the utility function of the employers, for example infrastructure. One must realize, however, that in most bargaining typically collective insurances/benefits that are developed for employees are taken into account. 


$$
\frac{d(W)}{d L}=\frac{R_{\nu} / \epsilon-W}{L}
$$

assuming, as before, that tax rates are determined exogenously.

\subsubsection{An efficient bargain}

As I have argued, I assume that the result at the central level can best be described by an efficient bargain. The bargain consists of wages and employment. Note that according to equation (9.2), the wage/employment combination determines the level of public goods, given the tariffs for the taxes and the premiums."

In chapter 3 I discussed the Nash bargain solution as a solution of an efficient bargain. Further I have shown that this solution can be analysed by the point of intersection of the contract curve and the rent division curve. In the coming analysis, 1 use this framework again. Before I continue, recall that from the model discussed in chapter 3 , the general expressions for the contract curve and the rent division curve are given in (9.6a) (equals equation 3.11) and (9.6b) (corresponds to equation A3.3) respectively: ${ }^{10}$

$$
\begin{gathered}
W=R_{L}+L \frac{U_{L}}{U_{W}} \\
W=R_{L}+\frac{\lambda}{1-\lambda} \frac{U_{L}}{U} \pi
\end{gathered}
$$

In the discussion of the model I basically analyse what happens with these curves. I can thus analyse whether and in what direction the wage rate and employment change

9. The charm of efficient bargaining is that the bargaining items can vary over a range of issues. Hence one could also assume that public goods are a bargaining item in the efficent bargain. However, since tax rates and tariffs are determined by the government and because the budget restriction must hold, a wage/employment bargain implicitly determines the amount of public goods that will be provided.

as

10. In the appendix to chapter 3 I defined $U=U(W, L)$ and $\pi=R(L)-W . L$ and the Nash solution

$\max N=U^{\lambda} \cdot \pi^{(1-\lambda)}$ Note, that since we now discuss the central level, $\lambda$ is the bargaining power at $W, L$

the central level. 
when I introduce in a standard model set-up, first taxes and thereafter government expenditures.

From equations $(9.1),(9.4),(9.6 \mathrm{a})$ and $(9.6 \mathrm{~b})$ I have calculated the contract curve and the rent division curve for three cases and the results of these calculations are summarized in Table 9.2. I have first calculated results for the 'standard' case (= column 2, case I: without taxes and government expenditures). Second, in column 3 I present results for the standard case including taxes (case II) and finally, column 4 gives the results for the standard case including taxes and government expenditures (case III). Hence in this way I can show the sequence of first introducing taxes and second introducing government expenditures in the model. The changes in the contract curve and in the rent division curve that follow when one moves from the standard case to case II and case III are summarized in Table 9.3 (p. 213). Finally, Figure 9.1 "translates" the results in a graph.

Table 9.2 Calculations for the contract curve and the rent division curve

\begin{tabular}{|c|c|c|c|}
\hline & $\begin{array}{l}\text { Case I } \\
\text { Standard case } \\
\delta=\varepsilon=1 ; \gamma+\theta=1\end{array}$ & $\begin{array}{l}\text { Case II } \\
+\delta, \varepsilon \\
\delta, c \neq 1 ; \gamma+\theta=1\end{array}$ & $\begin{array}{l}\text { Case III } \\
+\delta, \varepsilon ;+\mathrm{G} \\
\delta, \varepsilon \neq 1 ; \gamma+\theta \neq 1\end{array}$ \\
\hline $\begin{array}{l}\text { contract } \\
\text { curve }\end{array}$ & $W=R_{L}+\frac{\theta}{\gamma}\left(W-W^{\min }\right)$ & $W=\frac{R_{L}}{\epsilon}+\frac{\theta}{\gamma}\left(W-W^{\min }\right)$ & $\begin{array}{l}W=\frac{R_{L}}{\epsilon}+L B \\
B=\frac{\theta\left(W-W^{\min }\right)+\frac{(1-\gamma-\theta)}{(G)}\left(G_{L}\right)}{\gamma(L)+\frac{(1-\gamma-\theta)}{(G)}\left(G_{W y}\right)}\end{array}$ \\
\hline $\begin{array}{l}\text { rent } \\
\text { division } \\
\text { curve }\end{array}$ & $\begin{array}{c}W=R_{L}+\frac{\lambda}{1-\lambda} \frac{\theta}{(L)} A \\
\text { with } A=(R(L)-W L)\end{array}$ & $\begin{array}{r}W=\frac{R_{L}}{\epsilon}+\frac{\lambda}{1-\lambda} \frac{1}{\epsilon} \frac{\theta}{(L)} A \\
\text { with } A=(R(L)-\epsilon W L)\end{array}$ & $\begin{array}{l}W=\frac{R_{L}}{\epsilon}+\frac{\lambda}{1-\lambda} \frac{1}{\epsilon} \frac{\theta}{(L)} C \\
C=\left[\frac{1}{L}\right](R(L)-\epsilon W L)\end{array}$ \\
\hline
\end{tabular}


Case I.

The results for the standard case are derived when, $\delta=\varepsilon=(\mathrm{G})=1 ; \gamma+\theta=1$. It can be shown that if $1-(\theta / \gamma)<0$, the contract curve is positively sloped in $W$, L. This implies that the weight that the union places on employment must exceed the weight that is placed on the wage rate. This corresponds to the results that are found by Pencavel (1991), see also chapter 3. Further I note that the rent division curve is negatively sloping, (see chapter 3, appendix).

Case I is summarized in Figure 9.1. CCI and RDI are the contract curve and the rent division curve for case I respectively. The Nash bargaining solution is at the point of intersection of these curves. For case $\mathbb{I}$ this is point 1 .

\section{Case II.}

The introduction of both employers' and employees" taxes causes a change in the model set-up: in this case $\delta, \varepsilon \neq 1 ; \gamma+\theta=1$. If the results of case II are compared with case I, I find that the introduction of employers" taxes and premiums causes an upward shift of the contract curve because $d W / d \varepsilon>0$, provided that $1-(\theta / \gamma)<0$ (positively sloped contract curve (see appendix 9)). Note further that the slope of the contract curve depends on $\varepsilon$ as well. Thus the gross wages increase at each level of employment. The introduction of employees' taxes and contributions has no effect on the contract curve.

The rent division curve does not change when employees' taxes change. This is obvious because the rent division curve is independent of $\delta$. If employers" taxes increase, the rent division curve shifts downwards (in the $\mathrm{W}, \mathrm{L}$ space) with the tax increase. Because the elasticity of the gross wages with respect to employers" premiums can be shown to equal -1 , the difference between the "old" and the "new" rent division curve exactly equals the employers" tax rate."

I conclude that the introduction of employees" taxes and contributions has no effect on wage and employment. Employers' taxes cause an increase in the wage costs and a decrease in employment, the change in gross wages is indeterminate. I have again summarized the results in Figure 9.1. RDII is the rent division curve, excluding employers' premiums, while RDI is the curve including premiums. The point of intersection of CCII and RDII is the Nash solution in terms of gross wages, point 2. The corresponding wage costs can be found on RDI.

Il If one calculates the first derivative with respect to employers" premiums from the rent division curve including taxes, one finds $(d W / d \varepsilon)(\varepsilon / W)=-1+(\lambda /(1-\lambda)),(\theta / \varepsilon) W(1+(d W / d \varepsilon)(\varepsilon / W))$. This comes down to $(1+(d W / d \varepsilon)(\varepsilon / W))=0$. 
Although the change in gross wages cannot be determined beforehand, tax shifting has occurred.

Figure 9.1 Efficient bargains and the influence of taxes

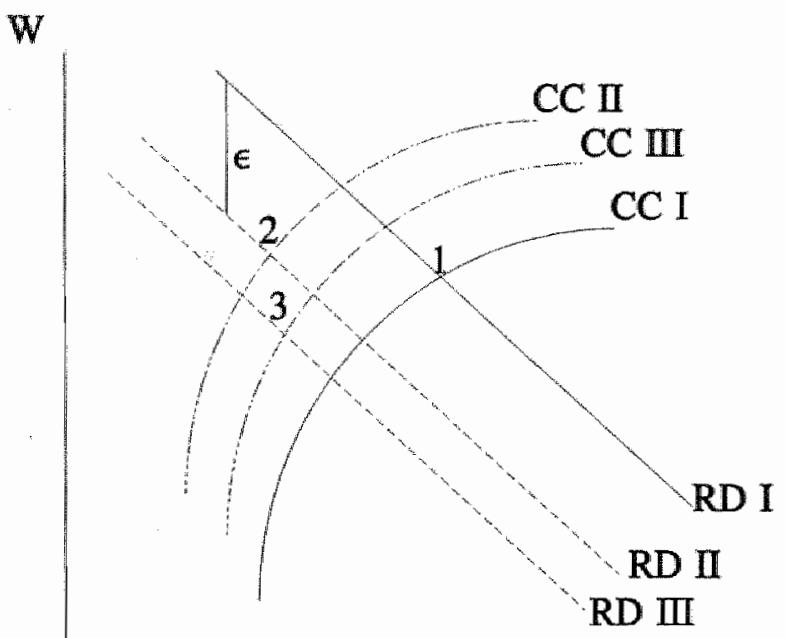

L

Case III.

If next case III is analysed, I derive that employers' premiums cause an upward shift of the contract curve. ${ }^{12}$ As before, employees' taxes do not influence the contract curve. Thus again the contract curve shifts upwards, although not as far as in case II. The introduction of government expenditures causes the rent division curve to shift downwards (compared to case II). This can be derived from the general expression of the rent division curve. Note that along the rent division curve employment is at such a level that the Nash maximand is maximized. Hence this curve is derived from

12 The direction of the movement depends on the sign of $1 /\{1-(\theta /[\gamma+(1-\gamma-\theta) / L)\}$. If this expression $<0$, the contract curve is positively sloped and $\mathrm{dW} / \mathrm{d} \varepsilon>0$. Compare this with the condition in case $I I$, where the sign of $d W / d \varepsilon$ depends on the sign of $1 /\{1-(\theta / \gamma)\}$. Since in case $I I, 1-(\theta / \gamma)<0$ in case of a positively sloped contract curve, $d W / d \varepsilon>0$. It is, however, obvious that $1 / 11-(\theta /[\gamma+(1-$ $\gamma-\theta) / L)\}<1 /\{1-(\theta / \gamma)\}$ and thus $\mathrm{dW} / \mathrm{d} \varepsilon$ in case III is smaller than in case II. Note that the difference depends partly on the value that is attached to public goods. 


$$
\frac{d\left(U^{\lambda} \pi^{(1-\lambda)}\right)}{d L}=0
$$

and for $R=R(L)$ one finds

$$
W=\frac{R_{L}}{\epsilon}+\frac{\lambda}{1-\lambda} \frac{1}{\epsilon} \frac{U_{L}}{U(. .)} \pi
$$

The inclusion of government expenditures will only change $U_{L} / U($.$) , which in this set-$ up equals $(\mathrm{dG} / \mathrm{dL}) /(\mathrm{G})=1 / \mathrm{L}$, (see also Table 9.2). For $\mathrm{L}>1$ in this model the rent division curve shifts downwards in comparison with case II. Since the latter shift does not occur in the previous case, the shift in the rent division curve is larger than in case II (from the view of case I). As before, the rent division curve is independent of employees' taxes. I have again summarized this case in Figure 9.1. RDIII and CCIII represent the rent division curve and the contract curve for case III respectively and point 3 is the Nash solution. It is clear that wage costs are lower and employment is higher than in case II, while the gross wages can be either higher or lower than in the previous case (Note that the employers' premiums are still measured by $\varepsilon$ ).

Table 9.3 The influence of employers' premiums, employees' taxes and contributions and valuation of government expenditures in a central level

\begin{tabular}{|c|c|c|c|c|c|c|c|c|c|c|}
\hline & \multicolumn{2}{|c|}{ case II } & \multirow[b]{2}{*}{$W$} & \multirow[b]{2}{*}{ Wc } & \multirow[b]{2}{*}{ L } & \multicolumn{2}{|c|}{ case III } & \multirow[b]{2}{*}{ W } & \multirow[b]{2}{*}{ Wo } & \multirow[b]{2}{*}{$L$} \\
\hline & $\mathrm{CC}$ & $\mathrm{RD}$ & & & & $\mathrm{CC}$ & $\mathrm{RD}$ & & & \\
\hline$\varepsilon \uparrow$ & $\uparrow \uparrow$ & $\downarrow$ & $?$ & $\uparrow \uparrow$ & $\downarrow \downarrow$ & $\uparrow$ & $\downarrow \downarrow$ & $?$ & $\uparrow$ & $\downarrow$ \\
\hline$\delta \downarrow$ & ni & ni & $\mathrm{ni}$ & ni & $\mathrm{ni}$ & ni & ni & ni & $\mathrm{ni}$ & ni \\
\hline
\end{tabular}
efficient bargain model

$\mathrm{CC}=$ contract curve; $\mathrm{RD}=$ rent division curve. $\mathrm{A} \uparrow$ is an upward movement, while a $\downarrow$ denotes a downward movement. Two arrows indicate that the effect is larger than in case of 1 arrow; ni no influence; ? = influence can be positive, negative or neutral. Note that the results are related to case I, the benchrmark case. An increase in $\varepsilon$ is an increase in employers" contributions while an decrease in $\delta$ is an increase in employees' taxes and social security contributions. 
To conclude, Table 9.3 summarizes the results of this analysis, comparing both case II and case III to case I. I conclude that employers' part of the premiums for social security contributions cause an increase in wage costs and a decrease in employment in an efficient bargain about wages and employment. This apparent "strange" result occurs because the contract curve moves along an unchanged rent division curve in terms of wage costs. ${ }^{13}$ Employees' taxes do not influence the bargaining outcome because in the set-up, the threat point is defined in terms of gross wages and therefore they do not influence the contract curve. ${ }^{14}$ If one assumes, however, that public goods are valued by the unions, tax shifting is less and lower wages and higher employment result (in comparison to case II). Thus the results between case II and case III do not differ in the direction of the effects, but in the magnitude of the effects. This theoretical result is in accordance with Cörvers and Van Veen (1995). They found that economies with highly centralized wage bargaining, are characterized by both higher taxes and higher government expenditures (as a percentage of GDP) relative to "decentralized" economies, while in other research a positive relation between centralization of wage bargaining and employment has been found, see chapter 5 .

\subsection{From the central level to the decentralized level: industry bargaining}

As has extensively been discussed in chapter 2 , in the Netherlands industry bargaining is the basis for collective labour agreements.

The modelling of industry bargaining after central bargaining gives rise to three questions. First, what is the relation between the outcome of the consultations at the central level and industry bargaining? This relation is complex. The main difficulty is that there are large differences between sectors concerning, for example, productivity, profits, unemployment and labour market conditions. These differences are of course hardly incorporated in the consultations that are held at the central level, but will be

13 Note that although there is a question mark with respect to the influence of employers' premiums on gross wages, I have argued that wage costs increase because in this case the rent division curve in terms of wage costs does not change. Further, I have called the result concerning the negative relation between wages and employment "strange" because the efficient bargain model has become famous for its positive relation between wages and employment. It will be obvious that the difference is that our analysis does not start at the labour demand curve (then the positive relation follows), but at an efficient solution point.

14 Note, referring to the previous chapter, how important the relation between taxes and the threat point is in reaching this result. If for example, the utility function was defined as $U=(\delta W$ $\left.W^{\text {nnin }}\right)^{\gamma}(L)^{\theta} G^{(1-\gamma-\theta)}$, this result does not hold, since in that casse employees' taxes influences the contract curve. 
incorporated in the industry contracts. I assume that for a typical industry, the results of the central consultations are an anchor point for the industry negotiations. More specifically, I will assume that industry unions regard the wage guideline as a minimum wage that can be reached in the negotiations. ${ }^{15}$ Second, how are the arguments of the union utility function at the industry level related to those of the central union? In my view, the union's preferences at the industry level differ from the umbrella unions. The main difference is that at the industry level, the unions are mainly interested in industry-specific goods. This means primarily that they are interested in industry wages and employment. Industry unions also value public goods, but only as far as they are relevant for the industry. Third, can industry bargaining, like central bargaining, also be modelled as an efficient bargain? In the Netherlands, there is wage bargaining (hence not monopolistic wage setting) at the level of the industry, but there is no bargaining about employment: employment is in general unilaterally set by the employers. Therefore, I conclude that at the level of the industry, the right-to-manage model is most suitable.

Industry bargaining can be modelled from the previous model as follows. I start with the utility function for industry $\mathrm{i}\left(\mathrm{U}^{\mathrm{i}}\right)$

$$
U^{i}=\left(\delta \cdot\left(W^{i}-W\right)\right)^{\beta} \cdot\left(L^{i}\right)^{\tau} \cdot\left(G^{j}\right)^{(1-\beta-\tau)}
$$

and the superscript $i$ denotes the level of the industry.

Equation (9.9) expresses that the utility for an industry union depends on industryspecific variables. Further I hypothesize that the union utility at the industry level depends on the difference between the industry wage $\left(W^{i}\right)$ and the wage that has been agreed upon at the central level and is recommended by the union federation to the industry unions (W). The reason is that the union is convinced that they can receive the central wage without further wage negotiations and consequently the aim of wage bargaining is to agree about a mark-up on the central wage.

With respect to employer's behaviour, it is assumed that employers strive after maximization of profits at the level of the industry. The profit function then reads

15 Here a difficult problem is touched upon. The umbrella unions have to my knowledge hardly ever explicitly stated that their wage guideline must be seen as a minimum. However, it is striking that in September 1996, the FNV announced a wage guideline and explicitly stated that this guidedine was meant as a moximum in order to create means for reduction in labour time, schooling and so on. Time will tell whether the industry unions perceive the guideline as a maximum. 


$$
\pi^{i}=R\left(L^{i}\right)-\epsilon \cdot W^{i} \cdot L^{i}
$$

As I have argued before, there is wage bargaining between unions and employers, while employment is set by employers unilaterally. This type of negotiation is known as the right-to-manage model. I further assume that the outcome of the bargaining process follows the asymmetric Nash solution with $\alpha$ being the bargaining power of the union and hence $I$ find $W^{i}$ from maximizing the Nash maximand

$$
\begin{aligned}
& \left.\underset{W^{i}}{\operatorname{Max}}\left[\left(\delta \cdot\left(W^{i}-W\right)\right)^{\beta} \cdot\left(L^{j}\right)^{\tau} \cdot\left(G^{j}\right)\right)^{(1-\beta-\tau)}\right]^{\alpha} \cdot\left[R\left(L^{i}\right)-\epsilon \cdot W^{i} \cdot L^{i}\right]^{1-\alpha} \\
& S T \quad R_{L}=\epsilon W^{i} \\
& W^{i}>W
\end{aligned}
$$

and this results in

$$
W^{i}=\frac{R\left(L^{i}\right)}{\epsilon \cdot L^{i}}-\frac{(1-\alpha)}{\alpha} \cdot \frac{\left(W^{i}-W\right)}{\beta+\tau E^{L^{i}\left(W^{i}-W\right)}}
$$

where $\mathrm{W}$ is the wage rate that is recommended at the central level ${ }^{16}$ and $E^{L^{i}\left(W^{i}-W\right)}$ the elasticity of employment with respect to wages.

If one takes a closer look at equation (9.12), one can make four remarks. Note first that the fact that public goods are valued by the industry unions does not

16 Note that this wage can be found from equating the rent division curve and the contract curve in case III (see previous section and Table 9.2)

$$
W=\frac{R(L)}{\epsilon \cdot L}-\frac{1-\lambda}{\lambda} \cdot \frac{\left(\delta W-W^{\min }\right)}{\gamma \cdot \delta+\frac{1}{G} \cdot E^{G_{U}}\left(\delta W-W^{\min }\right)\left(G_{W}\right)}
$$

with $E^{G_{U}}$ equals the elasticity of utility with respect to G (dU/dG. G/U). 
influence the bargaining outcome. The reason is that by assumption $\mathrm{dG}^{i} / \mathrm{dW}^{\mathrm{i}}=0 .{ }^{17}$ It is clear that in this case the unions cannot influence the amount of public goods at the level of the industry and hence these public goods do not influence the outcome. Second, one can derive that for a given level of employment,

$d W^{i} / d W=(1-\alpha) / \alpha\left(\beta+\tau E^{L^{i}\left(W^{i}-W\right)}\right)$. Since $E^{L^{i}\left(W^{i}-W\right)}<0$ one can conclude that for sufficient low elasticities of (industry) labour demand, $d W^{i} / d W>0$. Further, the larger the weight that is given to wages $(\beta)$, the more likely this term is positive which is quite intuitively. Third, note that, as in the previous case, in equation (9.12) an increase in $\varepsilon$ causes a decrease in the gross wages, while a change in $\delta$ has no effect. The intuition has been argued in the previous chapter: given the specification of the utility function, the Nash bargaining line is not influenced by the employees taxes and hence it remains in its place after the tax. This expresses the fact that unions cannot bargain for a better result. It is obvious that when both at the central level and at the industry level the bargaining parties behave according to after-tax prices, taxes are counted twice. Apart from the effect at the central level, an increase of employers' premiums causes a decrease in the gross wages at the level of the industry. The effect on the wage costs is positive as long as employers do not succeed in full backward shifiting. By taking the first derivative of (9.12) towards $\varepsilon$ it can be shown that a low elasticity of employment with respect to wages is a necessary condition for incomplete backward shifting. Table 9.3 summarizes the results concerning the influence of changes in employers' and employees' taxes on the gross wages, the wage costs and employment, all measured at the level of the industry.

Fourth, equation (9.12) shows the determinants of the contract wages in this type of two-tier system. The contract wages depend on both industry specific factors and outside (the industry) factors. This type of analysis closely resembles that in Layard et al. (1991) who claim that the wage rate depends on firm specific factors and

17 If this assumption was not made, $(9.12)$ would read

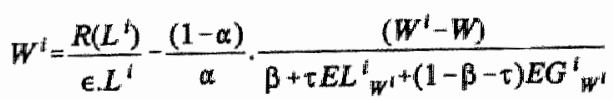

with $E L_{W^{i}}^{i}$ the elasticity with respect to wages and $E G^{i}$ is the elasticity of the government expenditures with respect to wages. It is obvious that then the valuation of public goods does play a role. 
outside factors ${ }^{18}$ and conclude that "(...) there is a considerable body of evidence that firm-specific or inside factors are important in wage determination, and that the degree to which they are important varies systematically across countries." (p. 189). The difference between this model and Layard's is that Layard et al. do not base their model on a multi-tier wage bargaining process, but define some outside (wage) opportunity in terms of macroeconomic variables. However, this chapter's approach permits a generalization of the idea that finally, the wage rate that employees receive is the result of a complex bargaining process in which both outside factors and inside factors are relevant.

Table 9.3 The influence of changes in employers' and employees' taxes on the gross wages, the wage costs and employment in the right-to-manage model for the industry level

\begin{tabular}{||l|l|l|l||}
\hline \hline & $\mathrm{W}^{\mathrm{i}}$ & $\mathrm{Wc}^{\mathrm{i}}$ & $\mathrm{L}$ \\
\hline$\varepsilon \uparrow$ & $\downarrow$ & $\uparrow$, condition & $\downarrow$, condition \\
\hline$\delta \downarrow$ & - & - & - \\
\hline $\mathrm{W} \uparrow$ & $\uparrow$ & $\uparrow$ & $\downarrow$ \\
\hline
\end{tabular}

I conclude first that modelling wage bargaining at the level of the industry in the light of the previous analysis of central consultations provides clear insight into the inside and outside factors in such a two-tier wage bargaining system. Second, in this chapter's model set-up, there is no theoretical foundation for shifting of employees taxes in the contract wages. The point is that when, after a change in the proportional tax rate, the gross mark-up does not change and hence the union cannot improve the bargaining result although their net mark-up has decreased: the union has to pay for these taxes. Further, as long as the bargaining parties cannot influence the level of public goods for their industry, tax shifting will not be lowered because of the provision of these goods.

18 Note that they assume that the contract wage results from bargaining at the firm level only. 


\subsection{Bargaining at the level of the firm}

The final step in the wage bargaining process is at the level of the firm. I have called this before wage drift (see chapter 4). In chapter 4 a model to explain wage drift, was developed. ${ }^{19}$ In this section I will extend the model with taxes. First, recall the model set-up, but now including taxes. ${ }^{20}$

$$
\operatorname{Max}\left(\delta\left(W^{f}-W^{\prime}\right)\right)^{c}\left[\pi\left(W^{f}, L^{j}\right)-\pi_{\min }\left(L^{j}\right)\right]^{1-c}
$$

with

$$
\begin{gathered}
\pi\left(W^{f}, L^{f}\right)=R\left[e\left(\delta W^{f}\right) L^{f}\right]-\epsilon W^{f} L^{f} \geq \pi_{\min }\left(L^{f}\right) \wedge W^{f}>W^{i} \\
\pi_{\min }\left(L^{f}\right)=\pi\left(W^{i}, L^{f}\right)=R\left[e\left(\delta . W^{f}\right) L^{f}\right]-\epsilon W^{i} L^{f}
\end{gathered}
$$

where the superscript $f$ denotes the level of the firm.

Equation (9.13) is the Nash maximand. It is assumed that the individual employee only cares about his wages, $W^{f}$ : i.e. about the mark-up above the contract wages $\left(W^{i}\right)$. The profit function $(9.14)$ is defined as in chapter 4 , but $I$ have now incorporated taxes. The same holds for the effort function and effort is now assumed to depend on net wages. Further, I now subtract wage costs from the revenues to define profit (for more details I refer to chapter 4). (9.15) defines minimum profits as the profits that are reached when the wage rate is equal to the contract wage, $W^{i}$. Note that an individual firm cannot influence $\mathrm{W}^{\mathrm{i}}$.

Note that employment is not an argument anymore in this utility function at the level of the firm. Referring to chapter 3, the utility function of an individual union member has been subject to much discussion (MDonald and Solow (1981), Oswald (1984;1987), Farber (1986), Pencavel (1991)), especially because of the contributions

19. Note that, as in chapter 4, wage drift is in this chapter the difference between the level of the earned wages and the level of the contract wages.

$20 \mathrm{c}$ is the bargaining power of the employee at the level of the firm. Note that in accordance with this chapter but contrary to the set-up in chapter $4, c$ is adduced to the employee and not the employer. 
by Oswald. He explains that if lay-offs follow some kind of inverse seniority principle (last in, first out), the average employee need not care about his or her employment and consequently the employment argument disappears from the utility function.

Solving equations $(9.13-9.15)$, one finds

$$
W^{f}=W^{i}+\frac{c}{(\epsilon-\delta . \alpha \cdot(1-c))} \frac{\left[R\left(\delta W^{f}\right)-R\left(\delta W^{j}\right)\right]}{L^{f}}
$$

with $W^{i}$ given by equation (9.12). As in chapter $4 \mathrm{I}$ use $R\left(\delta W^{f}\right)$ as a shortcut for $R\left(\delta W^{f}\right) L^{f}$ and $\alpha$ equals $R^{\prime}\left(\left(\delta W^{f}\right) L^{f}\right) e^{\prime}\left(\delta W^{f}\right)$.

Since $\varepsilon>1$, an increase in employers' premiums causes a decrease in the gross wages and hence employers succeed to shifting part of their burden also at the level of the firm. An increase in employees' premiums has three effects. First, it increases $\mathrm{R}\left(\delta \mathrm{W}^{\mathrm{f}}\right)-\mathrm{R}\left(\delta \mathrm{W}^{\mathrm{i}}\right) .^{21}$ Second, it influences $\delta . \alpha$. There is a direct influence that causes a decrease in $(c /(\varepsilon-\delta . \alpha .(1-c))$ and hence a decrease in the gross wages. However, since $\alpha$ equals $R^{\prime}\left(\left(\delta W^{f}\right) L^{f}\right) e^{\prime}\left(\delta W^{f}\right)$, a decrease in $\delta$ causes, additionally, an increase in $\alpha$ and thus an increase in $(c /(\varepsilon-\delta . \alpha .(1-c))$ again. It can be concluded that forward shifting in this model occurs when $\mathrm{d}(\delta . \alpha) / \mathrm{d} \delta<0$, i.e. when the elasticity of $\alpha$ with respect to $\delta$ (in absolute terms) $>1$.

One of the aims of this research was to analyse the influence of taxes in a three-tier wage bargaining model. I can now summarize the findings in Table 9.4. This table summarizes the results from the previous analyses. It shows the direction of the effects of a change in taxes on a change in gross wages and wage costs, per level (central bargaining, industry level, firm level) and both for the contract wage and the total wage.

From the analysis in section $9.3 \mathrm{I}$ conclude that if unions incorporate government expenditures in their utility function, tax shifting still occurs, but to a smaller extent. Further, in the right-to-manage model for industry wage bargaining, changes in employees' taxes do not influence the wage change. This does not hold for employers' taxes. Finally, we conclude that whether shifting of employees' taxes at the level of the firm occurs, depends on the relation between the change in the marginal returns and the tax change. Note that as with the empirical evidence (see chapter 8), the theoretical evidence is mixed too. The advantage of this theoretical analysis of tax shifting, however, is that careful analysis is possible of when shifting will occur.

21 A decrease in $\delta$ causes a decrease in both $R\left(\delta W^{f}\right)$ and $R\left(\delta W^{i}\right)$. However, since $W^{f}>W^{i}$, the decrease in $R\left(\delta W^{i}\right)>R\left(\delta W^{f}\right)$, because $R^{\prime}>0$ and $R^{\prime \prime}<0$. 
Table 9.4 The influence of taxes on wage costs and gross wages in the three-tier wage bargaining model

\begin{tabular}{|c|c|c|c|c|c|c|}
\hline & \multicolumn{2}{|c|}{$\begin{array}{l}\text { central } \\
\text { bargaining }\end{array}$} & \multirow[t]{2}{*}{$\begin{array}{l}\text { industry } \\
\text { level }\end{array}$} & \multirow[t]{2}{*}{$\begin{array}{l}\text { contract } \\
\text { wage }\end{array}$} & \multirow[t]{2}{*}{$\begin{array}{l}\text { firm } \\
\text { level }\end{array}$} & \multirow[t]{2}{*}{ total wage } \\
\hline & $\begin{array}{l}\text { case } \\
\text { II }\end{array}$ & $\begin{array}{l}\text { case } \\
\text { III }\end{array}$ & & & & \\
\hline $\mathrm{d} W / \mathrm{d} \varepsilon$ & $?$ & $?$ & $<0$ & $\begin{array}{l}d W / d \varepsilon+ \\
d W^{i} / d W+ \\
d W^{i} / d \varepsilon=?\end{array}$ & $<0$ & $\begin{array}{l}d W / d \varepsilon+ \\
d W i / d W+ \\
d W^{i} / d \varepsilon+ \\
d W f / d W^{i}+ \\
d W f / d \varepsilon=?\end{array}$ \\
\hline $\mathrm{dWc} / \mathrm{d} \varepsilon$ & $>0$ & $>0$ & $>0$, condition & $\begin{array}{l}\mathrm{dWc} / \mathrm{d} \varepsilon+ \\
\mathrm{dWc} / \mathrm{d} W \mathrm{c}+ \\
\mathrm{dWc} / \mathrm{d} \varepsilon= \\
>0\end{array}$ & $>0$ & 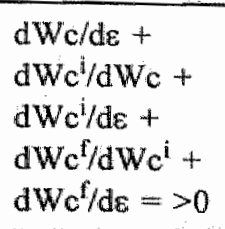 \\
\hline$d W / d \delta$ & $=0$ & $=0$ & $=0$ & $=0$ & $<0$, condition & $<0$, condition \\
\hline
\end{tabular}

\subsection{Conclusions}

In this chapter, I have analysed a three-tier wage bargaining model. I have analysed a sequential bargaining model, that consists of central consultations, industry wage bargaining and employee-firm bargaining. Efficient bargaining, right-to-manage and the inverse seniority model are used to model the bargaining process. In my view this type of model comes closest to the Dutch practice of wage negotiations. The model differs from other wage bargaining models because not only taxes, but also government expenditures are incorporated in the model. The main reason for this extension is that unions have showed, at least in the Netheriands, that they care about the provision of public goods and are willing to pay for these goods.

In the introduction to this chapter, I pointed to three questions that would be discussed in this chapter. First, concerning the modelling of wage negotiations at the various levels, I have first analysed central wage "bargaining" and made clear that there is in fact no bargaining at the central level in the Netherlands, but that the results of the consultations at the central level approach the outcomes that are reached in an efficient bargain model. Thereafter I analysed industry bargaining by way of a right-to- 
manage model. I assumed that industry unions strive after a mark-up on the centrally recommended wage rate and concluded that as long as there is no relation between the industry wage rate and the provision of public goods at the industry level, a valuation of public goods by the union is of no relevance in industry wage bargaining. Further, the results provide a foundation for what inside and outside factors determine the wage rate. Finally, I incorporated taxes in the model of wage drift that I developed in chapter 4. Second, the relation between the various levels is that in my view at each level attemps are made to receive a mark-up on the wage that is agreed upon at the higher level. This implies, as will be clear from the calculations, that certain effects cumulate. For example, it is assumed that at each level, net after-tax prices matter. Hence employers' taxes are shifted at each bargaining level. Third, I have concluded that in this model set-up, employers succeed in backward shifting to various degrees. Tax shifting by employees is less unambiguous: only at the central level and at the firm level one can derive evidence for tax shifting, although forward shifting by employees cannot be expected unconditionally in the efficiency wage model of wage drift. Finally, the results show that if unions incorporate the revenues of taxation in their negotiations, tax shifting will be lower than if they don't.

This model is a first attempt to develop a three-tier wage bargaining model for the Netherlands and a number of problems remain to be solved. I will mention two problems in particular. First, although at the central level parties are aware that their wage recommendation is seen as a minimum norm for the bargaining parties at the level of the industry, I have not discussed this effect on the outcome of the consultations at the central level. It is, however, possible that this influences the wage norm. For example, if employers' organizations have weak bargaining power at the level of the industry, the confederation of employers may find the wage that would result from the efficient bargain too high and resist to agree on a wage norm that would result from this efficient bargain at the central level. Second, the introduction of government expenditures in the utility function of the union is a relatively new appraoch. In particular the focus on that part of the expenditures that are seen as substitutes for private consumption is an alternative to the appraoch in which government expenditures are seen as complements to private consumption. It may be clear, that the way unions perceive government expenditures is a critical assumption for the results concerning the extend of tax shifting. Unfortunately however, there is hardly any empirical evidence on this point. 


\section{APPENDIX 9}

Case II

From Table 9.2 it follows that the contract curve can be written as

$$
W=\frac{1}{\left(1-\frac{\theta}{\gamma}\right)} \frac{R_{L}}{\epsilon}-\frac{1}{\left(1-\frac{\theta}{\gamma}\right)}\left(\frac{\theta}{\gamma} W^{\text {min }}\right)
$$

and it is obvious that only if $(1-(\theta / \gamma))<0$, does the contract curve show a positive slope. Further it can easily be derived that

$$
\frac{d W}{d \epsilon}=-\frac{1}{\left(1-\frac{\theta}{\gamma}\right)} \frac{R_{L}}{\epsilon^{2}} \quad>0
$$

Note that $\mathrm{dW} / \mathrm{d} \varepsilon$ is the partial derivative because it is derived for a given level of $\mathrm{L}$. 


\section{Chapter 10}

\section{SUMMARY AND CONCLUSIONS}

This chapter summarizes the findings of the researeh in section 101 , It is concluded that these studies have not only answered questions, but have also given rise to questions for further research. Section 10.2 discusses directions for future research

\subsection{Summary and conclusions}

This thesis discusses 3 topics: first, wage formation in the Netherlands and related to this, the question whether centralization or decentralization of wage bargaining is to be preferred; second, Dalton's Law and its application to wage bargaining models; third, a three-tier wage bargaining model for the Netherlands. In chapter 1 I have defined the 5 research questions that $I$ have been discussing in these series of studies.

One of the motives for this study was the increase in attention for tax shifting in the $1970 \mathrm{~s}$. Although there is ample evidence that tax shifting occurs in a number of OECD countries, the mechanisms behind this shifting are not fully clear. In my view, it is far too simple merely to assume that unions strive after net real wages and consequently try to shift taxes and premiums forward into higher wages. Since total wages are only partly controlled by the unions and total wages are used in almost all studies as the explanatory variable, this assumption is not really tested in the majority of studies.

In this thesis, I followed Booth $(1995$, p. 256$)$ who claims "[....] both the bargaining structure and the bargaining coverage are institutional features of an economy that need to be considered before constructing an aggregate model of the labour market" as a guideline for the research. From this point of view I formulated research questions 1 and 2 and this implies that $I$ start with an extensive analysis of the process of wage bargaining in the Netherlands and relate some striking features to recent theoretical developments in the fields of wage bargaining, wage drift and coordination problems. Thereafter starts the tax part with first an overview over the magnitude of the taxes (in relation to the gross wages), which is followed by an analysis of their impact in order to discuss research questions 3 and 4 . Finally, chapter 9 aims at an analysis of the influence of taxes in the specific context of the Dutch process of wage negotiations.

Chapters 2-5, chapters 6-8 and chapter 9 mark the various parts of this thesis. Chapters 2 and 3 discuss research question 1: the specific characteristics of wage 
formation in the Netherlands and the way they fit in existing wage bargaining theories. In chapter 2 I discussed the Dutch system of wage negotiations. Despite its complexity, one can conclude that both consultations at the central level and industry negotiations exist. In addition, there is wage drift in the Netherlands implying that the final wage is determined in negotiations between firms and individual employees. In order to be able to model wage determination in the Netherlands and focus on the role of taxation, I have taken a closer look at the concept of wage bargaining in chapter 3 , where I analysed modern approaches to the economics of trade unions and to unionfirm bargaining. I have concluded that apart from pure wage bargaining, bargains about both wages and employment can be used to describe union-firm bargaining. In my view, both the efficient bargain and the right-to-manage model are suitable for analysing the Dutch system of wage bargaining, although their suitability differs per level of negotiation. In chapter 4 I discussed research question 2 concerning the phenomenon of wage drift. I have developed a two-tier wage bargaining system to explain the wage drift component of the wages and used efficiency wage theory to explain why bargaining at the firm level can exist. This model explains first why wage drift will nearly always appear and second what the negative relation is between wage drift and the contract wage that is often found for the Netherlands. In chapter 2 I pointed out that the role of the central organization of employers and employees in the process of wage bargaining is both unclear and much discussed. The merits and demerits of centralization of wage negotiations were discussed in chapter 5.1 conclude that there is ample evidence that coordination of wage bargaining moderates the wage rate. Further, one can argue that the "second best" solution (uncoordinated wage bargaining at industry level) performs worse. Hence, the centralization-decentralization (i.e. industry level) debate in the Netherlands does make sense because the outcome will have an influence on the development of the wage rate.

Apart from the centralization-decentralization issue, the focus is on tax shifting. I presented the development of taxes and premiums for social security, both for employers and for employees in chapter 6 , which discusses research question 3 . In addition, I presented both aggregate figures and figures for the modal worker to measure the wedge at the level of the individual employee. One can conclude that the composition of the wedge has seriously changed: a shift from employers' to employees' premiums occurred during the $1980 \mathrm{~s}$ in the Netherlands. Moreover, the total wedge increased during the period $1960-1980$, followed by a decrease in the 1980 s. Further I conclude that the picture for the Netherlands resembles that of other OECD countries, although the wedge in the Netherlands is in general higher than elsewhere. Especially employees' part of the wedge is responsible for this result. 
Chapters 7 and 8 deal with the relation between taxes and wages and consequently discuss research question 4. Chapter 7 discusses at length Dalton's Law in a marketclearing model of wage determination. It is concluded that in such a market clearing model, elasticities of demand and supply determine tax shifting. Further I conclude that in such a model, Dalton's Law implies that it does not matter which side of the market is taxed. This means that the resulting increase in the wage costs, the net wages and employment is the same, regardless whether employers' or employees' taxes are increased. In chapter 8 I first check whether this strong result also holds for bargaining models. I conclude that only under very specific assumptions does Dalton's Law hold. The main assumption is that there are no threat points in the bargaining game. The relevance of this conclusion is that employees" taxes and contributions and employers'taxes and contributions can in general not be added together in empirical research, because their influence on the wage rate differs. Second, I give a review over empirical research concerning tax shifting, both in the Netherlands and in selected OECD countries. Tax shifting seems to be an important phenomenon in these countries and an inverted Haavelmo effect is not imaginary. Because I conclude that the measurement of tax shifting at the aggregate level lacks a sound theoretical foundation, one must still wonder how the shifting process works. During this thesis I have argued that an understanding of the way taxes are shifted needs a wage bargain model that captures the institutional characteristics of an economy. In the final chapter I give a first start for such a model for the Netherlands and discuss research question 5 . I have developed a three-tier wage bargaining system that captures the features of the Dutch system of wage negotiations. Key features of this model are first that it does not assume that the wage bargain model is the same at all levels and second that the union utility function differs between the central and the industry level. I conclude that this theoretical model is able to explain why tax shifting occurs mainly in the wage drift part of the wage rate. An important condition for this conclusion is that the unions do not only value wages and employment, but also have a keen eye for the "revenues of taxation" from which the unions benefit as well. It can be argued that the unions in the Netheriands do indeed value public goods. In the recent discussion in the Netherlands about the future role of the trade unions, however, this element of union policy is heavily being questioned by the unions themselves.

One might ask whether the results of these studies have any policy relevance. Although one must be careful in this respect, I think that one can at least discuss three points that are relevant for policy-making.

First, if one aims at continuous moderation of wages, then the dominance of industry negotiations seems to be the worst kind of bargaining structure. In the Netherlands however, the dominance of industry unions seems to be increasing and the 
role of the central organizations seems to be decreasing. Both unions and employers' organizations at the level of the industry seriously question the added value of their respective central organizations. This study concludes that in the light of wage moderation, a process of more far-reaching decentralization then is optimal. Hence, not industry negotiations, but negotiations at the level of the firm must be the final aim of decentralization. It seems however, that both unions and employers' ${ }^{\dagger}$ organizations aim at industry wide bargaining. In this respect, the abolition of the collective extension of the CAO's, needs to be considered as a step towards further decentralization. On the other hand, if industry unions and employers' organization are prepared to recognize the importance of central negotiations in coordinating their desires, the possibility of efficient bargaining must be catched. This might imply a more active role for the government in the foundation of labour.

Second, although employers' premiums have already reached an all-time lowest, there are still cries for a change in the composition of the wedge. If we use aggregate figures and use an elasticity of taxes on wages of 0.85 for employers and 0.35 for employees, the shift of the remaining $8 \%$ of the employers' premiums to employees will be about neutral with respect to wage costs. ${ }^{1}$ Third, as elsewhere in Europe, in the Netherlands there have been serious reductions in government expenditures. Consequently, the wedge has decreased. The latter is expected to have a negative (i.e. decreasing) influence on the development of wages. However, if the model of chapter 9 is an adequate description of the preferences of the Dutch trade unions, this effect can seriously be doubted. For, not only the decrease in the taxes is recognized by the unions, but also the reduction in the amount of public goods will be faced. This implies that employees have to pay more for previously "free" goods, like health care, social insurances, child care etc. If public goods are valued, this will exert a positive influence on the wage "claim" of the central unions. The net effect then is ambiguous. The assumed symmetry of tax shifting (high taxes, high wages and hence low taxes, low wages) needs much more investigation in this respect.

\subsection{Directions for further research}

These studies discuss a number of questions. Some have been solved, others not yet. One topic that is gaining increasing attention in the literature and that is not discussed in this thesis concerns the effect of a change in marginal tax rates and in the progressi-

This is calculated as follows. Employers' premiums amount to $8 \%$ of gross wages, hence $\varepsilon=$ 1.08. Employees taxes are $58 \%$ of gross wages, hence $\delta=0.42$. The shift implies a decrease in $\varepsilon$ of about $7.4 \%$, resulting in a decrease in wage costs of $6.3 \%$. The decrease in $\delta$ equals $19 \%$, raising the wage costs by about $6.7 \%$. 
vity of the tax system. In a number of studies (Hoel (1989), Padoa-Schioppa (1990), Graafland (1991), Lockwood and Manning (1993)) it is argued that an increase in marginal tax rates causes a decrease in the wage rate because this increase leads to the net revenues of a wage increase becoming lower than the revenues of an increase in employment. ${ }^{2}$ Further, the study is largely theoretical in character. One of the first extensions will be to make the model of chapter 9 suitable for empirical testing and of course estimate the parameters. Note that in this respect, it is interesting to follow the discussions that are held in the Dutch trade union movement. In the postwar period, the Dutch trade union has been well known for its sense of responsibility. However, in the late 1980s and early 1990s the role of the federation of unions and the strategy of the unions, especially concerning non-wages/employment goals, has been brought into discussion. The model that was developed in chapter 9 , predicts that if the valuation for public goods decreases, tax shifting will increase. Hence this change in strategy puts pressure on the financing of the welfare state. Further research with this model would permit a careful analysis of the consequences of a possible change in unions' strategy. Finally, the Dutch labour relations are often encapsulated in the term the "Rheinland model". This suggests that some major characteristics of the Dutch model are also applicable to other industrial countries, like Australia, Austria and Germany. An interesting topic for further research is to apply the model that I have developed in chapter 9 to these other countries.

2 The relation between the marginal wedge and the wage rate is controversial in the literature. The before mentioned studies argue that an increase in the marginal wedge implies that the value of a wage increase decreases. This will have a downward effect on the wage rate. The OECD, on the other hand, argues that high taxes have an upward effect on the wage rate and they wse the marginal wedge to illustrate this. 


\section{References}

Abraham, F. (1987), Bargaining Structures and Macroeconomic Performance in a Small Open European Economy with Imperfectly Compeitive World Markets, Discussion Paper 200, University of Michigan.

Abraham, F. (1989), Unions and Government: What does economic theory (not) tell us?, Ökonomie und Gesellschaft, 7, pp. 95-115.

Addison, J.T. and B.T. Hirsch (1986), The Economic Analysis of Unions, Boston, Allen \& Unwin.

Albeda, W. (1985), Einde van het inkomensbeleid? in: Economische arde en beleid,

Twintig jaren sociaal-economisch beleid, C. de Galan (ed), Deventer/Den Haag,

Kluwer/SER, pp. 127-139.

Albeda, W. (1990), Labour Relations in a Global Economy, Unpublished Paper.

Albeda, W, and A.P. van Veen (1990), Pleidooi voor een ander centraal akkoord, ESB, 75, no 3754, pp. 372-374.

Albeda, W. and W. Dercksen (1994), Arbeidsverhoudingen in Nederland, 5e druk, Alphen a/d Rijn, Samson.

Allen, R.G.D. (1975), Macro-economic Theory, London, Macmillan.

Asplund, R. (1989), A Bargaining Model of Tax Push Inflation, paper, published by the Economic Planning Centre, Helsinki, Finland.

Axelrod, R. (1984), The Evolution of Cooperation, New York, Basic Books.

Barten, A.P. and G. Carrin (1972), Macro-Economic Wage Equations for Five E.E.C. Countries, Tijdschrift voor economie, XVII, nr 3, pp. 313-323.

Barro, R. and D. Gordon (1983), Rules, discretion and reputation in a model of monetary policy, Journal of Monetary Economics, 12, pp. 101-121.

Beach, C.M. and F.S. Balfour (1983), Estimated Payroll Tax Incidence and Aggregate Demand for Labour in the United Kingdom, Economica, 50, pp. 35-48.

Bean, C., R. Layard and S. Nickell (1986), The Rise in Unemployment: A Multicountry Study, Economica, 53, supplement 210, S1-S22.

Binmore, K., A. Rubinstein and A. Wolinsky (1986), The Nash Bargaining Solution in Economic Modelling, Rand Journal of Economics, 17, no. 2, pp. 176-188.

Black, J. and G. Bulkley (1984), Union Utility Maximisation and Optimal Contracts, in Recent Advances in Labour Economics, G. Hutchinson and J. Treble (eds), London, Croom Helm.

Blanchard, O.J. and S. Fischer (1989), Lectures on Macroeconomics, Cambridge (MA), MIT Press.

Blinder, A.S. (1988), The Challenge of High Unemployment, Richard T. Ely Lecture, American Economic Review, Papers and Proceedings, 78, no. 2, May, pp. 1-15.

Booth, A. (1995), The Economics of the Trade Union, Cambridge, Cambridge University Press. 
Brandsma, A.S. and N. van der Windt, (1983), Wage Bargaining and the Phillips Curve: a Macroeconomic View, Applied Economics, 15, pp. 61-71.

Broeder, C. den (1996), Institutions at Work, Commitments and Flexibility on the German and Dutch Labour Markets, Research Memorandum No. 131, Centraal Planbureau, Den Haag.

Brown, J.N. and O. Ashenfelter, (1986), Testing the Efficiency of Employment Contracts, Journal of Political Economy, 94, no 3, pt 2, S40-S87.

Brunia, N. and G. Kuper (1990), De specificatie van de afwenteling van de collectieve lasten, Maandschrift Economie, 54, 1, pp. 49-55.

Bruno, M. and J.D. Sachs (1985), The Economics of Woridwide Stagflation, Cambridge (MA), Harvard University Press.

Burtless, G. and R. Haveman, (1987), Taxes, Transfers and Labor Supply: The Evolving Views of U.S. Economists, in The Relevance of Public Finance for Policy-Making, (Proceedings of the 41 st Congress of the International Institute of Public Finance), H. van de Kar and B. Wolfe (eds), Detroit, Wayne State University Press.

Butter, F. den (1991), Loonruimte, mythe of baken voor de loononderhandelingen, Report of a Symposium, Tinbergen Instituut, Maart.

Calmfors, L. (1985), Trade Unions, Wage Formation and Macroeconomic Stability An Introduction, The Scandinavian Journal of Economics, 87, 2, pp. 143-159.

Calmfors, L. and J. Driffill (1988), Centralization of Wage Bargaining, Economic Policy, 3, pp. 13-61.

Calmfors, L. (1993), Centralization of Wage Bargaining and Macroeconomic Performance - A Survey, OECD Economic Studies, no 21, pp. 161-191.

Cameron, D.R. (1984), Social Democracy, Corporatism, Labour Quiescence and the Representation of Economic Interest, in Advanced Capitalist Societies in Order and Conflict in Contemporary Capitalism, J.H. Goldthorpe (ed.) Oxford, Oxford University Press.

Carlin, W. and D. Soskice (1990), Macroeconomics and the Wage Bargain, Oxford, Oxford University Press.

Carruth, A. and A.J. Oswald, (1985), Miners" Wages in Post-War Britain: An Application of a Model of Trade Union Behaviour, The Economic Journal, 95, December, pp. 1003-1020.

Carruth, A., A.J. Oswald and L. Findlay (1986), A Test of a Model of Trade Union Behaviour: the Coal and Steel Industries in Britain, Oxford Bulletin of Economics and Statistics, 48, nr 1, February, pp. 1-18.

Centraal Bureau voor de Statistiek $(1984 ; 1987 ; 1991 ; 1993)$, Sociaal-economische maandstatistiek, in particular: Reyn, $\mathrm{H}$. van, Earnings and wage rates; a com- 
parison of trends, 1972-1982, Supplement 1984, no. 10; Werf, R.E.J. van der, Comparison of trends in earnings and wage rates, 1977-1985, Supplement 1987, no. 1; Van den Berg, J.JJ. Takkenberg, Trends in Average Gross Wages in the period 1985-1988, Supplement 1991, no. 1; Hesemans, J. Wage-development 1985-1993, (hourly wages), Supplement 1993, no. 6 .

Centraal Bureau voor de Statistiek (1975), Indexcijfers van Regelingslonen, methodebeschrijving en reeksen 1926-1974, Den Haag, Staatsuitgeverij.

Centraal Bureau voor de Statistiek (1987), Indexcijfers van Regelingslonen, methadebeschrijving en reeksen 1926-1985, Den Haag, Staatsuitgeverij.

Centraal Planbureau (1977), Een Macro-model voor de Nederlandse Economie op middellange termijn (VINTAF II), Occasional Papers, no. 12, Den Haag.

Centraal Planbureau (1983a), Freia, een Macro-economisch model voor de middellange termijn, Monografie 25, Den Haag.

Centraal Planbureau (1983b), Kompas, kwartaalmodel voor prognose, analyse en simulatie, Monografie 26, Den Haag.

Centraal Planbureau (1992), FKSEC: A Macroeconomic Model for the Netherlands, Stenfert Kroese, Leiden/Antwerpen

Centraal Planbureau (1995), Replacement Rates: A Transatlantic View, Working Paper No. 80 , Den Haag.

Centraal Planbureau, Macro-economische Verkenningen, various volumes.

Centraal Planbureau, Centraal Economisch Plan, various volumes.

CCSO, Centrum voor conjunctuur en structuuronderzoek (1986), The CCSO Anmual model of the Dutch Economy, CCSO series, nr. 3, University of Groningen, Groningen.

Coe, D.T. and F. Gagliardi, (1985), Nominal Wage Determination in Ten OECD Countries, OECD, Working Papers, no 19, March.

Cooper, R. and A. John (1988), Coordinating Coordination Failures in Keynesian Models in: Mankiw and Romer, vol. 2.

Compaijen, B. and J.A. Vijlbrief (1994), Benefits and Unemployment in an open economy: An Equilibrium Analysis, Applied Economics, 26, pp. 765-774.

Cörvers, $\mathbb{F}$. and A.P. van Veen (1992), Corporatisme en economische ontwikkeling, $E S B, 77$, no 3889 , pp. 1189-1193.

Cörvers, F. and A.P. van Veen (1995), On the Measurement of Corporatism, Labour, 9, no 3, pp. 423-442.

Creedy, J. and I. McDonald (1991), Models of Trade Union Behaviour: A Synthesis, The Economic Record, December, pp. 346-359. 
Crouch, C. (1985), Conditions for Trade Union Wage Restraint in The Politics of Inflation and Economic Stagnation, L. Lindberg and C. Maier (eds), Washington, Brookings Institution.

Dalton, H. (1954), Principles of Public Finance, London, Routledge and Kegan.

Damme, E. van (1990), Speltheorie, ESB, 75, nr 3782, pp. 1036-1042.

Delsen, L: and A.P. van Veen (1992), The Swedish Model: Relevant for other European Countries?, British Journal of Industrial Relations, 30, no. 1, pp. 83105 .

Dertouzos, J.N. and JH. Pencavel, (1981), Wage and Employment Determination under Trade Unionism: The International Typographical Union, Journal of Political Economy, 89, no 6, pp. $1163-1181$.

Diamond, P. (1988), Aggregate-Demand Management in Search Equilibrium, in Mankiw and Romer, vol. 2.

Dienst Collectieve Arbeidsvoorwaarden (1992), CAO-afspraken medio 1992 in relatie tot het Gemeenschappelijk Beleidskader, juni, Ministerie van Sociale Zaken en Werkgelegenheid, 's-Gravenhage.

De Nederlandsche Bank (1984), MORKMON: een kwartaalmodel voor macroeconomische beleidsanalyse, Monetaire Monografieën $\mathrm{Nr}$. 2, Kluwer, Deventer.

De Nederlandsche Bank (1990), MORKMON II: het DNB kwartaalmodel voor Nederland, Monetaire Monografieën 11, NIBE, Amsterdam.

Doel, J. van den, (1978), Demokratie en Welvaartstheorie, 2e druk, Alphen aan de Rijn, Samson.

Doel, J. van den, C. de Galan and J. Tinbergen (1976), Pleidooi voor een geleide loonpolitiek, Economisch-Statistische Berichten, 61, no 3044, pp. 264-268.

Driehuis, W. (1975), Inflation, Wage Bargaining, Wage Policy and Production Structure: Theory and Empirical Results for the Netherlands, De Economist, 123, no 4, pp. 638-679.

Driehuis, W. (1980), Enige aspecten van loonontwikkeling en loonbeleid in de jaren zeventig, Economisch-Statistische Berichten, 65, no. 3243, pp. 200-213

Driffill, J. (1985), Macroeconomic Stabilization Policy and Trade Union Behavior as a Repeated Game, The Scandinavian Journal of Economics, 87, 2, pp. 300-334 (including comments).

Drimmelen, W., N. van Hulst and $\mathrm{C}_{\text {. de }}$ Kam (1981; 1995), Loonvorming en loonpolitiek in Nederland, Groningen, Wolters-Noordhoff.

Dunlop, J.T. (1944); Wage Determination under Trade Unions, New York, A.M. Kelley.

Elliot, R.F. (1991), Labor Economics, London, McGraw-Hill. 
Farber, H.S. (1986), The Analysis of Union Behavior, in Handbook of Labor Economics, O. Ashenfelter and R. Layard (eds.), Vol. II, pp. 1039-1089, Amsterdam, Elsevier/North Holland.

Fase, W.J.P.M. (1980), Vijfendertig jaar loonbeleid in Nederland, Alphen a/d Rijn, Samson.

Freeman, R. and J. Medoff (1984), What do Unions do?, New York, Basic Books.

Freeman, R. (1988), Labour Market Institutions and Economic Performance, Economic Policy, 6, pp. 64-80.

Frankel, J. and K. Rockett (1988), International Macroeconomic Policy Coordination when Policymakers Do Not Agree on the True Model, American Economic Review, June, pp. 318-341.

Galan, C. de, (1957), De invloed van de vakvereniging op loonshoogte en werkgelegenheid, proefschrift, Leiden.

Gerfin, H. (1969), Ausmass und Wirkung der Lohndrift, in Lohnpolitik und Einkommensverteilung, Schriften des Vereins fuer Socialpolitik, H. Arndt (ed.) Berlin, Von Duncker und Humblot, pp. 471-522.

Gordon, R.J. (1971), Inflation in Recession and Recovery, Brookings Papers on Economic Activity, 1, pp. 105-166.

Gordon, R.J. (1975), The Impact of Aggregate Demand on Prices, Brookings Papers on Economic Activity, 3, pp. 613-670.

Gordon, R.J. (1982), Inflation, Flexible Exchange Rates and the Natural Rate of Unemployment, in Workers, Jobs and Inflation, M. Baily (ed), Washington, The Brookings Institution, pp. 89-158.

Gordon, R.J. (1987), Productivity, Wages and Prices inside and outside of manufacturing in the U.S., Japan and Europe, European Economic Review, 31, pp. 685-739. Graafland, J. (1990), Persistent Unemployment, Wages and Hysteresis, Dissertation, Helmond.

Graafland, J. (1991), Effecten van marginale belasting- en premiedruk op loonvorming, Research Memorandum, no 78, Centraal Planbureau, 's-Gravenhage.

Grubb, D., R. Jackman and R. Layard, (1983), Wage Rigidity and Unemployment in OECD Countries, European Economic Review, 21, pp. 11-39.

Gylfason, T. and A. Lindbeck (1986), Endogenous Unions and Governments, European Economic Review, 30, 1, pp. 5-26.

Hall, R.E. and D.M. Lilien, (1979), Efficient Wage Bargains under Uncertain Supply and Demand, American Economic Review, 69, no 5, pp. 868-879.

Hamermesh, D.S. (1979), New Estimates on the Incidence of the Payroll Tax, Southern Economic Journal, 45, pp. 1208-1219. 
Hartog, H den (1984), Empirical Vintage Models for the Netherlands: a Review in Outline, De Economist, 132, 3, pp. 326-349.

Hartog, J. (1991), Loonruimte en loonstructuur in micro-economisch perspectief, Report of a Symposium, Tinbergen Instituut, Maart.

Hersoug, T., K.N. Kjaer and A. Rodseth (1986), Wages, Taxes and the Utility Maximizing Trade Union: a Confrontation with Norwegian Data, Oxford Economic Papers, 38, pp. 403-423.

Heijke, J.A.M., J. de Koning, R.J.M. Maas and G. den Broeder (1972), AMO-K, een Arbeidsmarktmodel met Twee Categorieën Arbeid, Nederlands Economisch Instituut, Rotterdam.

Hicks, J.R. (1932), The theory of wages, London, MacMillan.

Hieser, R.O. (1970), Wage Determination with Bilateral Monopoly in the Labour Market, Economic Record, March, pp. 55-72.

Hines, A.G. (1964), Trade Unions and Wage Inflation in the United Kingdom 18931961, Review of Economic Studies, XXXI (1), no. 85, January, pp. 221-252.

Hoel, M. (1989), Efficiency Wages and Local versus Central Wage Bargaining, Economics Letters, 30, pp. 175-179.

Hoel, M. (1990), Efficiency Wages and Income Taxes, Journal of Economics, 51, 1, pp. 89-99.

Holden, S. (1988), Local and Central Wage Bargaining, The Scandinavian Journal of Economics, 90, 1, pp. 93-99.

Holmlund, B. (1983), Payroll Taxes and Wage Inflation: The Swedish Experience, Scandinavian Journal of Economics, 85, 1, pp. 1-15.

Holmlund, B. (1986), Centralized Wage Setting, Wage Drift and Stabilization Policies under Trade Unionism, Oxford Economic Papers, 38, pp. 243-258.

Hulst, N. van, (1984a), De invloed van de vakbeweging op de loonvorming, Maandschrift Economie, 48, pp. 317-337.

Hulst, N. van (1984b), De effectiviteit van geleide loonpolitiek in theorie en praktijk, Groningen, Wolters-Noordhoff.

Jackman, R., C. Pissarides and S. Savouri (1990), Labour Market Policies and Unemployment in the OECD, Economic Policy, 11, October, pp. 450-490.

Jackman, R., R. Layard and S. Nickell (1996), Combatting Unemployment: Is Flexibility Enough? Proceedings OECD-Conference: Macroeconomic Policies and Structural Reform, OECD, Paris.

Jacobs, J. and M. Janssen (1990), Coordinating Unions Wages and Employment, De Economist, 138, pp. 321-339.

Johnston, J. (1972), A Model of Wage Determination under Bilateral Monopoly, Economic Journal, 82, september, pp. 837-852. 
Johnston, J., and M. Timbrell (1973), Empirical Tests of a Bargaining Theory of Wage Rate Determination, The Manchester School of Economic and Social Studies, 41, no. 2, pp. 141-167.

Johansen, K. (1995), Dynamic Modeling of the Wage Formation Process in a TwoTiered Bargaining System, paper, presented at the EALE conference, Gothenburg 1996.

Johansen, L. (1979), The Bargaining Society and the Inefficiency of Bargaining, Kyklos; 32, pp. 497-522.

Kam, C.A. de (1996), Tax Reform in the Netherlands, 1985-1995, in C.J.M. Kool, J. Muysken and T. van Veen (eds), Essays in Money, Banking and Regulation, Boston, Kluwer, pp. 187-215.

Keizer, P.K. (1982), Inflatie: een institutionele benadering, proefschrift, Groningen.

Keizer, P.K. (1984), Inflatietheorie en anti inflatiepolitiek, Groningen, Wolters Noordhoff.

Keizer, P.K. (1986), Wage Formation in the Context of Collective Bargaining, De Economist, 134, 2, pp. 191-213.

Keller, W.J. (1980), Tax Incidence, A General Equilibrium Approach, Amsterdam, Elsevier/ North Holland.

Keus, J.M. (1980), Rendementen die geen winsten zijn, Economisch Statistische Berichten, 65, no 3247 , pp. 335-340.

Keus, J.M. (1981), Beroering over Inkomensquoten, Economisch Statistische Berichten, 66 , no. 3291 , pp. 109 .

Keynes, J.M. (1936), The General Theory of Employment, Interest and Money, (Edition 1973), Cambridge, Macmillan/Cambridge University Press.

Knoester, A. (1983), Stagnation and the Inverted Haavelmo Effect: Some International Evidence, De Economist, 131 , nr 4, pp. 548-584.

Knoester, A. (1988), Supply-side policies in four OECD countries in: Economic Modelling in the OECD countries, H. Motamen (ed.), London, Chapman and Hall.

Knoester, A. and N. van der Windt, (1985-87), Real Wages and Taxation in Ten OECD Countries, Discussion Paper 8501 G/M, Erasmus University Rotterdam; revised version in Oxford Bulletin of Economics and Statistics, (1987), 49, no 1, pp. 151-169.

Koutsoyiannis, A. (1979), Modern Microeconomics, London, Macmillan.

Kramer, P. (1979), Twijfels rond de afwenteling in het model VINTAF-II, Economisch Statistische Berichten, 64, no 3231, pp. 1221-1227. 
Krapels, F. and A. van Ravestein (1987), Gemiddeld en Marginaal, De druk van belastingen en premies sinds 1960, Onderzoeksmemorandum nr. 6, Ministerie van Economische Zaken (AEP), Den Haag.

Kuh, E. (1967), A Productivity Theory of Wage Levels; An Alternative to the Phillips Curve, Review of Economic Studies; XXXIV, pp. 333-360.

Layard, R. (1989), European Unemployment: Cause and Cure, Discussion Paper 368,

Centre for Labour Economics, London School of Economics, London.

Layard, R. and S. Níckell (1987), Is Unemployment Lower if Unions Bargain over Employment? Working Paper no. 955, London School of Economics, May.

Layard, R., S. Nickell and R. Jackman (1991), Unemployment, Oxford, Oxford University Press.

Lecq, F. van der (1996), Conventions and Institutions in Coordination Problems, De Economist, 144, no. 3, pp. 397-428.

Leontief, W. (1946), The Pure Theory of The Guaranteed Annual Wage Contract, Journal of Political Economy, 54, no 1, February, pp. 76-79.

Lever, M. (1993), Union wage formation and (un)employment, Dissertation 93-17, Faculty of Economics and Business Administration, University of Limburg, Maastricht.

Lever, M. and T. van Veen (1991), Union Wage Setting, Employment and Investment:

a Survey of Theory and Empirical Evidence, Labour, 5, 3, pp. 25-62.

Lipsey, R.G. (1960), The Relation between Unemployment and the Rate of Change of Money Wage Rates in the United Kingdom, 1862-1957: A Further Analysis, Economica, February, pp. 1-31.

Lockwood, B. and A. Manning (1993), Wage Setting and the Tax System, Theory and evidence for the United Kingdom, Journal of Public Economics, 52, 1, pp. 1-29.

Luce, R.D. and H. Raiffa (1957), Games and Decisions: Introduction and Critical Survey, Willey, New York.

MaCurdy, T.E. and J.H. Pencavel, (1986), Testing between Competing Models of

Wage and Employment Determination in Unionized Markets, Journal of Political

Economy, 94, no 3, pt 2, pp. S3-\$39.

Malcomson, J. (1987), Trade Union Labour Contracts: An Introduction, European Economic Review, 31, no 1/2, February/March, pp. 139-149.

Malcomson, J. and N. Sartor (1987), Tax Push Inflation in an Unionized Labour Market, European Economic Review, 31, 8, pp. 1581-1596.

Mamuith, H.A. (1992), Markteconomie, Utrecht.

Manning, A. (1987), An Integration of Trade Union Models in a Sequential Bargaining Framework, The Economic Journal, 97, pp. 121-139. 
Mankiw, N. and D. Romer (1991), New Keynesian Economics 1 and 2, Cambridge (MA), MIT Press.

McCallum, J. (1983), Inflation and Consensus in the Seventies, Economic Journal, 93, pp. 784-805.

McCallum, J. (1986), Unemployment in the OECD countries, Economic Journal, 96, pp. 944-963.

McDonald, I.M., and R.M. Solow, (1981), Wage Bargaining and Employment, American Economic Review, 71, no 5, pp. 896-908.

McDonald, I.M. and A. Suen (1992), On the Measurement and Determination of Trade

Union Power, Oxford Bulletin of Economics and Statistics, 54, 2, pp. 209-223.

Ministerie van Sociale Zaken en Werkgelegenheid (1995), Sociale Nota 1995, Den Haag.

Moene, K.O. (1988), Unions' Threats and Wage Determination, The Economic Journal, 98, June, pp. 471-483.

Moene, K.O., M. Wallerstein and M. Hoel (1992), Bargaining Structure and Economic Performance, Memorandum 10, Faculty of Economics, University of Oslo.

Mulder, C. (1989), New Classical Macroeconomics, Trade Unions and Unemployment, $\mathrm{Ph} . \mathrm{D}$ thesis, London School of Economics and Political Science.

Mulder, C. and F. van der Ploeg (1989), Trade Unions, Investment and Employment in a Small Open Economy: A Dutch Perspective, in Unemployment in Europe, J. Muysken and C. de Neubourg (eds), pp. 200-226, London, Macmillan.

Mulder, C. (1990), Langdurige werkloosheid in Nederland, ESB, 75, no. 3744, pp. 132-136.

Musgrave, R.A. and P.B. Musgrave (1987), Public Finance in Theory and Practice, 4th ed., New York, McGraw-Hill.

Muysken, J. and A.P. van Veen (1993), Efficiency Wages and Local Wage Bargaining, Research Memorandum 93-035, Rijksuniversiteit Limburg, Maastricht.

Muysken, J. and A.P. van Veen (1996a), Efficiency Wages and Local Wage Bargaining, Scandinavian Journal of Economics, 98, 1, pp. 119-127.

Muysken, J. and A.P. van Veen (1996b), It does matter which side of the market is taxed, in C.J.M. Kool, J. Muysken and T. van Veen (eds), Essays in Money, Banking and Regulation, Boston, Kluwer.

Nash JR, J.F. (1950), The Bargaining Problem, Econometrica, 18, pp. 155-162.

Nash JR, J.F. (1953), Two-person Cooperative Games, Econometrica, 21, pp. 128-140. Nickell, S.J. and M. Andrews, (1983), Unions, Real Wages and Employment in Britain 1951-79, Oxford Economic Papers, 35, Supplement, November, pp. 183-206.

OECD (1978), Public Expenditure Trends, June, Paris.

OECD (1994), The OECD Jobs Study, Paris. 
Olson, M. (1971), The Logic of Collective Action, Harvard Economic Studies, volume CXXIV, Cambridge (MA), Harvard University Press.

Oltoff, R. and P. de Gijsel (1996), Local Wage Bargaining, Efficiency Wages and the Wage Gap: A Game-Theoretic Approach, unpublished paper, University of Limburg, Maastricht.

Oswald, A. (1982), The Microeconomic Theory of the Trade Union, The Economic Journal, 92, September, pp. 576-595.

Oswald, A. (1984), Efficient Contracts are on the Labour Demand Curve, Theory and Facts, Working Paper/178, Industrial Relations Section, Princeton, July.

Oswald, A. (1985), The Economic Theory of Trade Unions, An Introductory Survey, Seandinavian Journal of Economics, 87, nr 2, pp. 160-193.

Pais, A. (1976), Liever geen illusies, Economisch-Statistische Berichten 61 , no 3054, pp. 503-504.

Padoa Schioppa, F. (1990), Union Wage Setting and Taxation, Oxford Bulletin of Economics and Statistics, 52, 2, pp. 143-167.

Parkin, M., M. Sumner and R. Ward (1976), The Effects of Excess Demand, Generalized Expectations and Wage-Price Controls on Wage Inflation in the UK: 19561971, in: Economics of Price and Wage Controls, K. Brunner and H. Meltzer (eds), Amsterdam.

Pen, J. (1952), A General Theory of Bargaining, American Economic Review, XIII, 1, pp. 24-42.

Pen, J. (1957), Verschraling en oververzadiging in de loontheorie, De Economist, 105 , pp. 737-753.

Pen, J. (1991), Loonruimte, looninflatie en het schrikbeeld van de loon-prijsspiraal, Report of a Symposium, Tinbergen Instituut, Maart.

Pencavel, J. (1984), The Tradeoff between Wages and Employment in Trade Union Objectives, The Quarterly Journal of Economics, XCIX, no 2, May, pp. 215-231.

Pencavel, J. (1985), Wages and Employment under Trade Unionism: Microeconomic models and Macroeconomic Applications, Scandinavian Journal of Economics, 87 , nr 2, pp. 197-225.

Pencavel, J. (1991), Labor Markets under Trade Unionism, Oxford, Basil Blackwell. Peters, H.I.M. (1992), Axiomatic Bargaining Game Theory, Kluwer Academic Publishers.

Phillips, A. (1958), The Relation Between Unemployment and the Rate of Change of Money Wage Rates in the United Kingdom, 1861-1957, Economica, 25, November, pp. 283-299.

Raiffa, H. (1982), The Art and Science of Negotiation, Cambridge (MA), Harvard University Press. 
Rasmusen, E. (1989), Games and Information, Oxford, Basil Blackwell.

Rompuy, P. van, G. de Bruyne and C. van de Voorde (1988), Taxation, Wages and Employment in a Unionized Economy, Tijdschrift yoor Economie en Management, XXXIII, no. 3-4, pp. 261-270.

Ridder, P.B. de (1976), Het verband tussen inflatie, afwenteling en arbeidsinkomensquote, Maandschrifi economie, 41, no. 3/4, pp. 126-139.

Rubinstein, A. (1982), Perfect Equilibrium in a Bargaining Model, Econometrica, 50 , 1, pp. 95-109.

Santomero, A.M. and J.J. Seater (1978), The Inflation-Unemployment Trade-off: A critique of the Literature, Journal of Economic Literature, XVI, pp. 499-544.

Sargan, J.D. (1980), A Model of Wage-Price Inflation, Review of economic Studies, XIVVII, pp. 97-112.

Scarpetta, S. (1996), Assessing the Role of Labour Market Policies and Institutional Settings on Unemployment: A Cross Country Study, OECD Economic Studies, 26, 1, pp. 43-98.

Schmidt, M. (1982), Does Corporatism Matter?, in Patterns of Corporatist Policy Making, G. Lehmbruch and P. Schmitter (eds), London, Sage Publications.

Siddré, W. (1985), Flexibilisering van de arbeidsmarkt; in Preadviezen over de flexibilisering van de arbeidsmarkt, Organisatie voor Strategisch Arbeidsmarktonderzoek, OSA- voorstudie nr 9, 's-Gravenhage, Staatsuitgeverij.

Sinderen, J. van (1990), Belastingheffing en economische groet, Groningen, WoltersNoordhoff.

Sociaal-economische Raad (1992), Convergentie en overlegeconomie, Advies inzake convergentie en overlegeconomie, SER publikatie 15 , november.

Soskice, D. (1990), Wage Determination: the Changing Role of Institutions in Advanced Industrialized Countries, Oxford Review of Economic Policy, 6, no. 4, pp. 36-61.

Stichting van de Arbeid (1982), Centrale aanbevelingen inzake aspecten van een werkgelegenheidsbeleid, november, Stichting van de Arbeid, 's-Gravenhage.

Stichting van de Arbeid (1992), Sociaal-economische Beleidsoriëntaties, publikatie 10/92, Stichting van de Arbeid, 's-Gravenhage.

Stichting van de Arbeid (1993), Een nieuwe koers, publikatie 9/93, Stichting van de Arbeid, "s-Gravenhage.

Stiglitz, J.E. (1988), Economics of the Public Sector, 2nd ed., New York, Norton.

Sumner, M.T. and R. Ward (1983), The Reappearing Phillips-Curve, Oxford Economic Papers, Special Supplement, November, pp. 307-320. 
Svejnar, J. (1986), Bargaining Power, Fear of Disagreement, and Wage Settlements: Theory and Evidence from U.S. Industry, Econometrica, 54, no 5, September, pp. 1055-1078.

Tanzi, V. (1980), Inflation and the Personal Income Tox, Cambridge University Press, Cambridge.

Theeuwes, J. (1988), Arbeid en belastingen, in Belastingheffing en belastinghervorming, Preadviezen voor de Vereniging van de Staathuishoudkunde, Leiden, Stenfert Kroese.

Thomson, W. (1994), Cooperative models of Bargaining in: Handbook of Game Theory, R. Aumann and S. Hart (eds), vol. 2, pp. 1238-1284, North Holland, Elsevier.

Tobin, J. (1972), Inflation and Unemployment, in Modern Macroeconomics, P.G. Korliras and R. S. Thom (eds), New York, Harper \& Row.

Tullio, G. (1987), Long Run Implications of the Increase in Taxation and Public Debt for Employment and Economic Growth in Europe, European Economic Review, 31, pp. 741-780.

Tweede Kamer der Staten Generaal, Miljoenennota, various volumes.

Ulph, A. and D. Ulph (1990), Union Bargaining: A Survey of Recent Work in: Current Issues in Labour Economics, D. Sapsford and Z. Tzannatos (eds), London, Macmillan.

Varian, H. (1984), Microeconomic Analysis, 2nd. ed., Norton, New York.

Veen, A.P. van, (1987), Afwenteling in de loonvergelijking -een empirische studie, Research Memorandum, RM 87-001, Rijksuniversiteit Limburg, Faculteit der Economische Wetenschappen, Maastricht.

Veen, A.P. van and A. van der Veen, (1987), De Afwenteling van collectieve lasten in Nederland, Maandschrift Economie, 51, no.5, pp. 330-347.

Veen, A. van der and A. P. van Veen, (1987), Payroll Tax Shifting and Tax Push Inflation: Evidence for the Netherlands, Research Memorandum, RM 87-032, Rijksuniversiteit Limburg, Maastricht;

Veen, A.P. van (1989), Utility Maximizing Trade Unions: Some Comments, Research Memorandum, RM 89-015, Rijksuniversiteit Limburg, Maastricht.

Vroman, W. (1974), Employers payroll Taxes and Money Wage Behavior, Applied Economics, 6, pp. 189-204.

Weitenberg, J. (1969), The Incidence of Social Security Taxes, Public Finance, XXIV, pp. 193-208.

Wemelsfelder, J. (1979), De Arbeidsinkomensquote en afwentelingstheorie, Economisch-Statistische Berichten, 64, no 3217, pp. 808-811. 
Wilke, M. (1991), Corporatism and the Stability of Capitalist Societies Frankfurt a. $M$, Peter Lang.

Windmuller, J. (1969), Labour Relations in the Netherlands, Ithaca, N.Y., Cornell University Press.

Windmuller, J. and C. de Galan (1977), Arbeidsverhoudingen in Nederland, Utrecht, Het Spectrum.

Wijngaert, R. v.d (1994), Trade Unions and Collective Bargaining in the Netherlands, Thesis, Amsterdam, Thesis Publishers.

Yellen, J.L. (1984), Efficiency Wage Models of Unemployment, American Economic Review, Papers and Proceedings, 74, pp. 200-205. 


\section{Summary (in Dutch)}

Dit proefschrift bestaat uit een aantal studies rondom 3 onderwerpen. Ten eerste wordt de loonvorming in Nederland onder de loep genomen met daaraan gerelateerd de vraag in hoeverre centralisatie of decentralisatie in de loonvorming de voorkeur verdient (hoofdstukken 2-5). Dit vraagstuk is actueel gezien de toenemende roep on decentralisatie in de loonvorming bij zowel de vakbonden als de werkgeversverenigingen. Ten tweede wordt de invloed van belastingen op de loonvorming geanalyseerd. Twee modellen worden bekeken: het model van volkomen mededinging en vervolgens worden de bevindingen toegepast op onderhandelingsmodellen (hoofdstuk 7-8). Niet alleen de invloed van de omvang van de wig wordt geanalyseerd, maar ook de invloed van de verdeling van de wig over werkgevers en werknemers. Dit vraagstuk is actueel omdat er regelmatig discussie is (geweest) over de vraag hoe premies voor sociale verzekering statutair moeten worden verdeeld over werkgevers- en werknemersaandelen. Tenslotte wordt een aanzet gegeven voor een 3-fasen model voor de analyse van de Nederlandse loonvorming (hoofdstuk 9). Kempunt van dit model is dat een rol is weggelegd voor de besprekingen die op centraal niveau al dan niet leiden tot een centraal akkoord.

De keuze voor deze 3 onderwerpen vloeit voort uit de motivatie om dit proefschrift te schrijven: de toenemende belangstelling voor de rol van belastingen en sociale premies in de loonvorming. De resultaten van veel onderzoek wijzen in de richting van het bestaan van een belasting-loon spiraal: een stijging van de belastingen/premies wordt gevolgd door een loonstijging. Dit verschijnsel staat bekend als afwenteling van belastingen en premies. Als dit afwentelingsgedrag vervolgens leidt tot een stijging van de werkloosheid, dan zullen de premies verder stijgen en zo verder. De eerlijkheid gebiedt overigens te zeggen dat er evenzeer onderzoeksresultaten zijn die geen verband tussen belastingen en lonen kunnen traceren. Merk op dat het verschil niet te wijten is aan een andere periode of een ander land.

Een nadere bestudering van het onderzoek naar de belasting-loon spiraal leidde tot de conclusie dat de theoretische onderbouwing van het verschijnsel "afwenteling" te wensen overlaat. Met name op twee punten. In de eerste plaats wordt in het meeste onderzoek geen of nauwelijks een verband gelegd met de theorie over afwenteling zoals die bekend is uit de leer van de overheidsfinancien. In de tweede plaats staat het: empirische model op basis waarvan afwenteling wordt onderzocht, vaak los van elke institutionele context. Dit laatste heeft gevolgen voor de conclusies die kunnen worden getrokken. Bijvoorbeeld: als men in het onderzoek ervan uitgaat dat vakbonden streven naar behoud van het netto reële inkomen en men vindt een positieve relatie tussen de ontwikkeling van de belastingen en de ontwikkeling van de loonkosten, dan is de conclusie dat vakbonden afwenteling veroorzaken, prematuur. Immers, in Nederland (als in de meeste West-Europese verzorgingsstaten) onderhandelen de vakbonden over het contractloon. Dit verschilt van het feitelijk verdiende loon door het bestaan van het 
incidentele loon. Ofwel, nadat het contractloon is bepaald wordt er op individueel niveau onderhandeld over een eventuele opslag op dit loon. Als nu met name dit incidentele loon voor afwentelingseffecten zorgt, dan kunnen de vakbonden niet verantwoordelijk worden gesteld voor afwenteling.

In deze serie studies wordt getracht Dalton's Law te koppelen aan moderne loonvormingstheorieën. Voorts wordt getracht de institutionele structuur van de Nederlandse arbeidsverhoudingen te incorporeren in een model dat de loonvorming in Nederland analyseert.

De hoofdstukken 2-5, 6-8 en 9 markeren de verschillende delen waaruit dit proefschrift bestaat. Hoofdstuk 2 gaat in op de wijze waarop de loonvorming in Nederland plaatsvindt. Uit de institutionele context volgt in de eerste plaats dat over de lonen in Nederland wordt onderhandeld. In de tweede plaats bestaat er in Nederland een looncomponent waarover de bonden niet onderhandelen, het zogeheten incidentele loon (earnings gap). Tenslotte blijkt uit een beschrijving van de institutionele context dat er in Nederland een voortdurend debat is over de vraag op welk niveau de loononderhandelingen "moeten" plaatsvinden. Deze drie elementen worden in de hoofdstukken 3-5 verder uitgewerkt. Hoofdstuk 3 analyseert moderne loononderhandelingstheorieën. Er worden 3 modellen bediscussieerd, het monopolie model, het loononderhandelingsmodel en het efficiënte onderhandelingsmodel. Er wordt geconcludeerd dat in de Nederlandse institutionele verhoudingen elk van de modellen een plaats zou kunnen hebben. Hoofdstuk 4 behandelt het incidentele loon. In dit hoofdstuk wordt aangehaakt bij recent onderzoek, met name uit de Scandinavische landen, naar dit verschijnsel. In dit onderzoek wordt het bestaan van het incidentele loon verklaart uit individuele onderhandelingen op het niveau van een onderneming. Er wordt onderhandeld over een opslag op het contractloon. Werknemer(s) kunnen door te dreigen met een staking of met stiptheidsacties de werkgevers bewegen een bepaalde opslag te betalen. Een probleem is dat het produktiviteitsverlies dat resulteert uit acties van werknemers exogeen bepaald is. De invalshoek die in dit proefschrift is gekozen is dat werknemers qua produktiviteit gevoelig zijn voor financiële prikkels. Een hoger loon leidt tot een hogere produktiviteit en onder bepaalde voorwaarden, tot een hogere winst. Daardoor kan het voor de onderneming gunstig zijn een loon te betalen dat boven het contractloon ligt. Op deze wijze kan het min of meer permanente karakter van het incidentele loon worden verklaard. Hoofdstuk 5 gaat in op de discussie over centrale versus decentrale onderhandelingen. In dit hoofdstuk wordt beargumenteerd dat afzonderlijke vakbonden geen prikkels hebben om vrijwillig tot loonmatiging over te gaan, zelfs niet als zij. van mening zijn dat loonmatiging te prefereren is boven geen loonmatiging. De reden is dat de afzonderlijke bonden bang zijn dat zij als enige loon matigen, terwijl de andere bonden dit niet doen. Dat leidt tot een verslechtering van de relatieve positie 
van de bond die matigt: In dergelijke gevallen is een zekere mate van coördinatie dus gewenst ter verwezenlijking van vrijwillige loonmatiging. Deze gedachte heeft geleid tot een veelheid van onderzoek naar de vraag of centralisatie in de loononderhandelingen tot betere economische prestaties leidt dan gedecentraliseerde onderhandelingen. Dit onderzoek wordt besproken en de conclusie luidt dat niet-gecoördineerde onderhandelingen op het niveau van de bedrijfstak tot slechtere economische prestaties leiden dan ofwel centrale onderhandelingen ofwel onderhandelingen op het niveau van het bedrijf.

In de tweede serie studies, hoofdstukken 6-8, staat de wig en de invloed van de wig op de uitkomst van het loonvormingsproces centraal. De wig wordt gedefinieerd als de som van de belastingen en de totale premies en is bijgevolg precies gelijk aan het verschil tussen de loonkosten voor de werkgever en het netto loon voor de werknemer. In hoofdstuk 6 wordt de omvang van de wig onderzocht. Zowel aan de hand van cijfers uit de nationale rekeningen (de zogenoemde macro cijfers) ais door middel van het opstellen van een gefingeerde belasting-/premie aangifte voor een modale werknemer (de zogenoemde micro-cijfers) wordt de wig in verhouding tot het bruto loon uitgerekend. Zowel de macro cijfers als de micro cijfers laten een stijging van de wig tot begin jaren ' 80 zien, gevolgd door een daling. Verder is het opvallend dat de samenstelling van de wig is veranderd: het werknemersaandeel is sterk gestegen en thet werkgeversaandeel dus sterk gedaald. De majeure verschuiving als gevolg van de operatie-Oort van eind jaren ' 80 is een logisch gevolg van deze tendens geweest. Vervolgens wordt de omvang van de wig in Nederland vergeleken met die in een aantal andere OECD-landen. De Nederlandse ontwikkeling spoori vrij goed met de ontwikkeling in de onderzochte landen. Er zijn echter wel belangrijke niveauverschillen. Daarnaast blijkt dat in Nederland met name de inkomstenbelasting en werknemerspremies voor een relatief hoge wig zorgen. Hoofdstuk 7 analyseert de invloed van de wig op de arbeidsmarkt en gaat nader in op het begrip afwenteling. Hierbij wordt verondersteld dat de arbeidsmarkt een goed functionerende markt is: prijzen zorgen telkens weer voor evenwicht en er zijn geen machtsposities. De conclusie is dat de introductie van de wig leidt tot een stijging van de prijs (loonkosten) en een daling van de hoeveelheid (werkgelegenheid). Bovendien blijken de resultaten niet te verschillen of nu de werkgevers dan wel de werknemers worden belast. Het maakt voor de verandering in de loonkosten en de werkgelegenheid niet uit hoe de statutaire verdeling van de wig is. Deze bekende conclusie uit de leer van de openbare financiën wordt uitgebreid geanalyseerd. In hoofdstuk 8 wordt de analyse van hoofdstuk 7 vervolgd, maar nu voor een arbeidsmarkt die gekenmerkt wordt door loononderhandelingen. Er worden 2 modellen bekeken. De keuze voor deze modellen is ingegeven door het gebruik in het empirisch onderzoek naar afwenteling. Ten eerste een model waarbij de lonen 
een gewogen gemiddelde zijn van de loonvraag van de werknemers en het loonaanbod van de werkgevers. De wegingscoefficiënten zijn de machtsverhouding tussen werkgevers en werknemers. In dit model blijven de conclusies uit hoofdstuk 7 geldig. Het maakt niet uit welke kant van de markt wordt belast, zolang de machtsverhoudingen niet veranderen door een verandering in de samenstelling van de wig. Daarna wordt het loononderhandelingsmodel dat in hoofdstuk 3 al is geanalyseerd, aangevuld met belastingen en premies. Er wordt geconcludeerd dat de vraag of het uitmaakt welke kant van de markt wordt belast, afhankelijk is van de specificatie van de nutsfunctie en van het bestaan van en de wijze van definitie van een dreigpunt in de onderhandelingen. Tenslotte wordt in hoofdstuk 8 ingegaan op het vele onderzoek naar afwenteling, zowel voor Nederland als voor een aantal andere OECD landen.

Hoofdstuk 9 is het derde deel van dit proefschrift. In dit hoofdstuk wordt een aanzet gegeven voor een loononderhandelingsmodel waarin zowel centrale onderhandelingen als bedrijfstakonderhandelingen als onderhandelingen op het niveau van het bedrijf een plats hebben. De reden om een dergelijk model te ontwikkelen is ingegeven door de Nederlandse institutionele context, waarin op deze drie niveaus over lonen en werkgelegenheid wordt gesproken dan wel onderhandeld. In dit hoofdstuk worden twee nieuwe ideeën uitgewerkt. In de eerste plaats wordt de idee dat het onderhandelingsmodel op alle niveaus hetzelfde is, doorbroken. Er wordt verondersteld dat op centraal niveau het efficiënte onderhandelingsmodel een adequaat model is, terwijl op het niveau van de bedrijfstak het loononderhandelingsmodel, waarbij de werkgever énzijdig de werkgelegenheid bepaalt, de beste beschrijving van de onderhandelingen geeft. Op het niveau van de onderneming is het in hoofdstuk 4 behandelde model ter verklaring van het incidentele loon gebruikt. In de tweede plaats wordt er in de onderhandelingen op het centrale niveau en op het ondernemingsniveau expliciet plaats ingeruimd voor de opbrengsten van collectieve goederen. Dit gebeurt door het expliciet als argument opnemen van deze goederen in de nutsfunctie van de vakbonden. Dit idee is wel eens in de literatuur gelanceerd, maar nog niet expliciet uitgewerkt. Hoewel het model nog niet in al zijn facetten is geanalyseerd, volgt uit de eerste theoretische analyses dat het opnemen van collectieve goederen in de nutsfunctie van de vakcentrales tot lagere afwentelingseffecten leidt. Verder volgt uit het model dat werkgevers een gedeelte van de belastingen kunnen afwentelen en werknemers nauwelijks. Dit correspondeert met resultaten van empirisch onderzoek en kan de reden zijn waarom een verandering van werkgeverspremies een groter effect heef op de loonkosten dan een verandering van de werknemerspremies, zoals herhaaldelijk is geconstateerd.

Hoofdstuk 10, tenslotte, sluit het proefschrift af met de samenvatting en de conclusies. Ten aanzien van het te volgen beleid op de arbeidsmarkt kom ik tot de conclusie dat de roep van de vakbonden om meer decentralisatie alleen tot een mati- 
ging van de lonen leidt als dit wordt vergezeld van het afschaffen van de dominantie van het industrieniveau als onderhandelingsniveau. Dit kan door het afschaffen van de algemeen verbindend verklaring voor collectieve arbeidsovereenkomsten. Aan de andere kant moeten de vakbonden zich realiseren dat indien coördinatie in de loononderhandelingen wordt gewenst (bijvoorbeeld via de algemeen verbindend verklaring), dit met zich mee brengt dat er cen plaats is voor vakcentrales en dat de adviezen van deze centrales niet vrijblijvend mogen zijn. Ten tweede kom ik tot de conclusie dat het overhevelen van de resterende $8 \%$ aan werkgeverspremies naar de werknemers neutraal zal uitwerken op de loonkosten, gegeven de mate van afwenteling en de orde-grootten die optreden. Tenslotte volgt uit het door mij ontwikkelde model dat indien aan collectieve goederen een waarde door de vakcentrales wordt toegekend, de verlaging van de collectieve lasten niet hoeft te leiden tot een verlaging van de loonvraag omdat tevens een daling in het voorzieningenniveau van de collectieve goederen optreedt. 


\section{Curriculum Vitae}

Tom van Veen (Arnhem, 1953) studied business administration at the HEAO in Arnhem. After the fulfilment of his military service, he started studying economics at the Erasmus University in Rotterdam and he continued his study at the University of Groningen. He received his masters degree in 1983 (with distinction).

After a temporary appointment as a teacher at the University of Groningen, he was appointed as assistant professor at the University of Maastricht, faculty of economics and business administration. While he started lecturing mainly in macroeconomics and labour economics, his teaching shifted onto financial economics, especially international financial markets and the European Monetary System. Tom van Veen has been author/co-author of articles in ESB, Maandschrift Economie, Labour, British Journal of Industrial Relations and the Scandinavian Journal of Economics. During the period January-August 1997 Tom van Veen stayed at the University of Newcastle, as a visiting research fellow. 